Making Exclusionary Processes in Schools Visible

Gro Emmertsen Lund 


\section{Graduation Committee:}

\section{Chairman and Secretary:}

Prof. dr. Th. A. J. Toonen, University of Twente

\section{Supervisors:}

Prof. dr. C. P. M. Wilderom, University of Twente

Prof. dr. J. Winslade, California State University of San Bernardino, USA

\section{Committee Members:}

Prof. dr. A. Visscher, University of Twente

Prof. dr. J. W. M. Kessels, University of Twente

Prof. dr. K. J. Gergen, Swarthmore College, USA

Prof. dr. S. McNamee, University of New Hampshire. USA

Prof. dr. J. Rijsman, University of Tilburg 


\title{
MAKING EXCLUSIONARY PROCESSES IN SCHOOLS VISIBLE
}

\section{DISSERTATION}

\author{
to obtain \\ the degree of doctor at the University of Twente, \\ on the authority of the rector magnificus, \\ prof. dr. T. T. M. Palstra, \\ on account of the decision of the graduation committee, \\ to be publicly defended \\ on Friday, the $10^{\text {th }}$ of November, 2017 at 16.45 hrs.
}

by

Gro Emmertsen Lund

born on the $5^{\text {th }}$ of August 1975

in Esbjerg, Denmark 
This PhD dissertation has been approved by:

Prof. dr. C. P. M. Wilderom (Supervisor)

Prof. dr. J. Winslade (Supervisor)

Cover design: Gro Emmertsen Lund

Copyright @ 2017 Gro Emmertsen Lund, Ribe, Denmark. All rights reserved. No part of this publication may be reproduced or utilized in any form or by any electronic, mechanical or by any means, now known or hereafter invented, including photocopying and recording without otherwise the prior written approval and permission of the author.

ISBN: 978-90-365-4418-4 


\section{Making exclusionary processes}

\section{in schools visible}

"Our son was frustrated and with that sometimes aggressive. His frustration was met with aggression by the school (..). We were convened to meetings to discuss what was now talked about as our son's behavior problems. We had asked both teachers and principal to listen to us to try to see things from our son's perspective. Each time they nodded, but continued their focus on our son being a troublemaker."

A mother, Short story 2

"In schools that had an aggressive or passive predisposition, there was a strong tendency towards a culture that regarded issues on individualistic ways - behavior, attendance and progress were invariably construed as the individual responsibility of the students. Deviations invariably invoked retribution that resulted in predictable consequences, which were always couched officially in terms of failure on the part of the student to take personal responsibility. This frequently came across in ways that made it appear as 'common sense', in which the (in)actions on the part of the student justifiably provoked the response by the school."

Smyth \& Hattam, 2004, p. 168 
Contents:

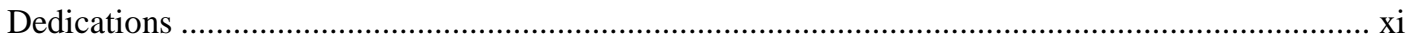

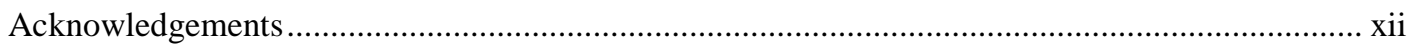

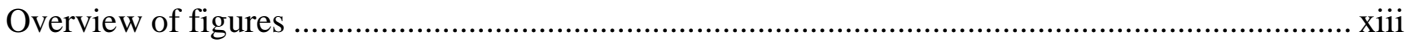

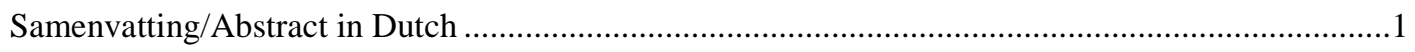

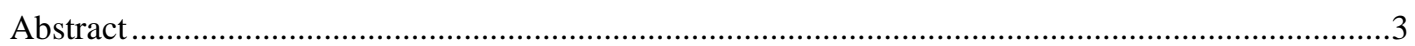

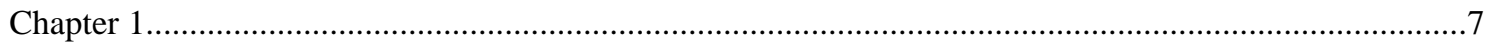

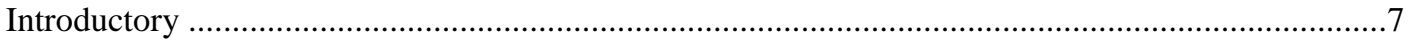

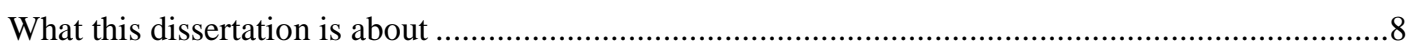

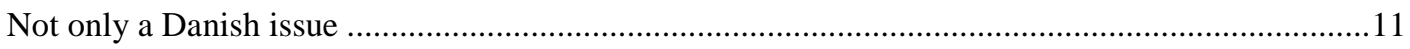

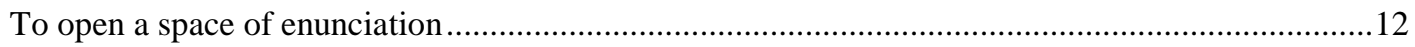

Inviting parents' perspectives into the conversation .........................................................................13

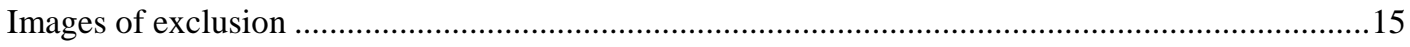

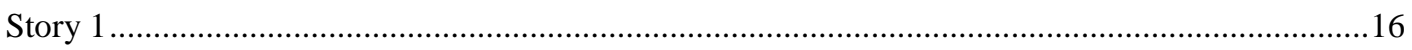

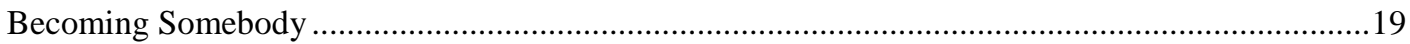

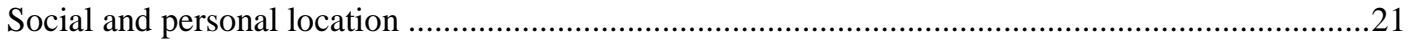

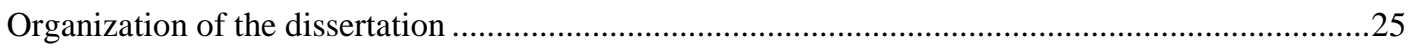

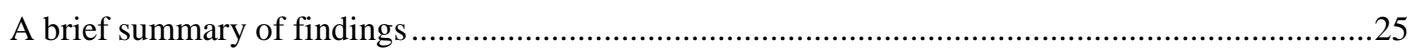

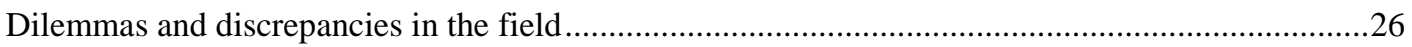

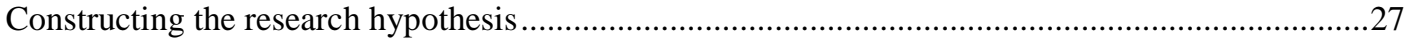

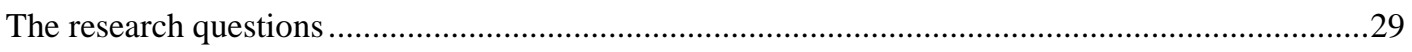

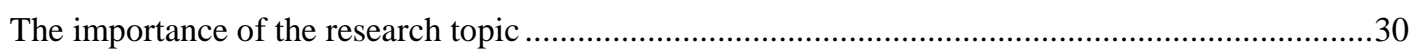

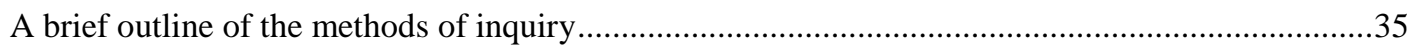

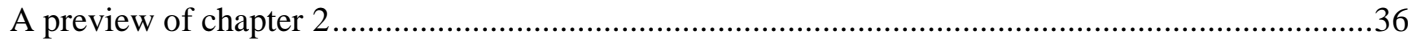

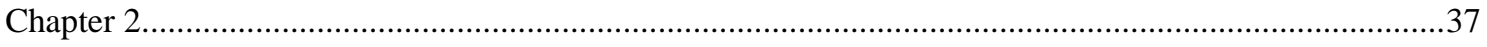

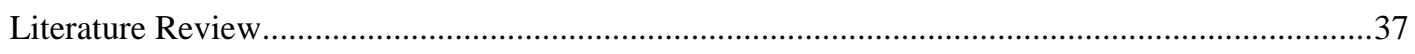

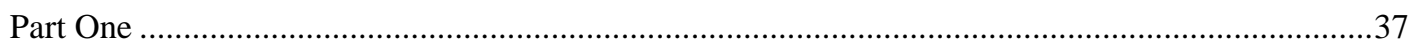

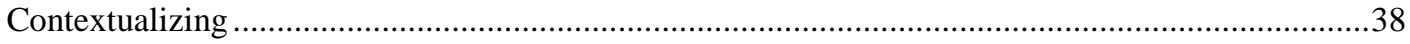

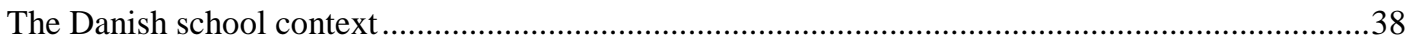

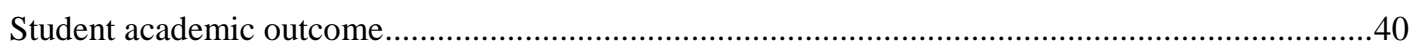

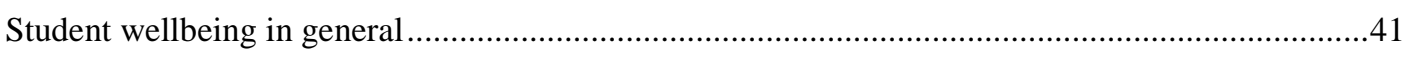

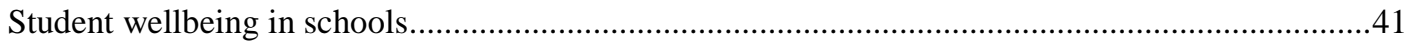

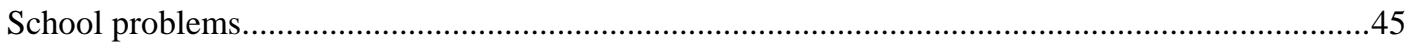

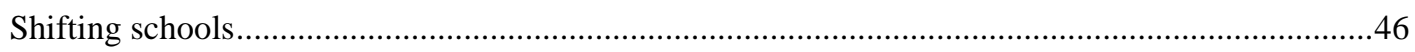

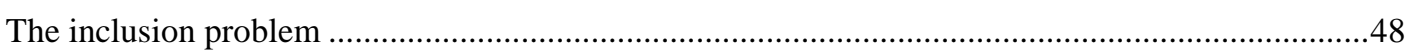


Dealing with problem behavior in schools.

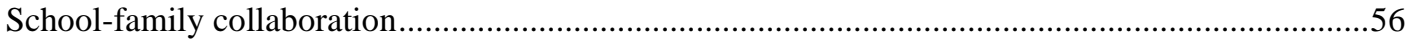

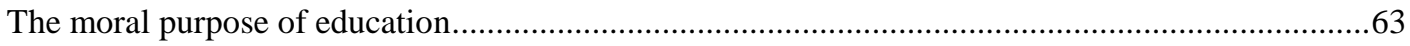

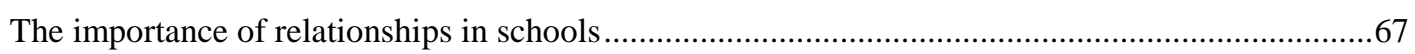

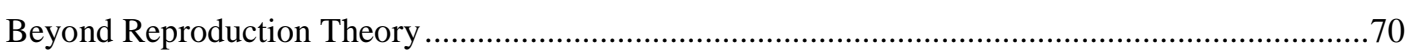

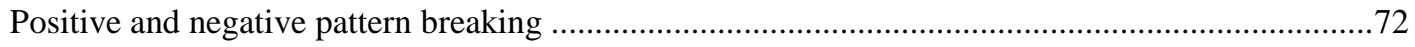

When family background cannot explain social marginalization .....................................................72

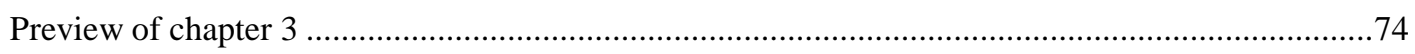

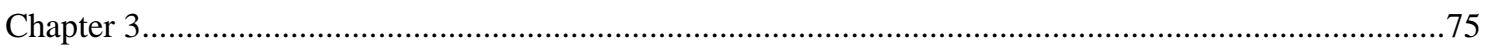

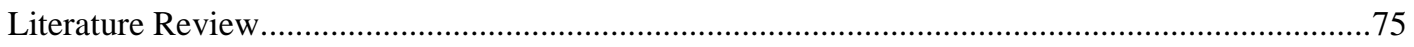

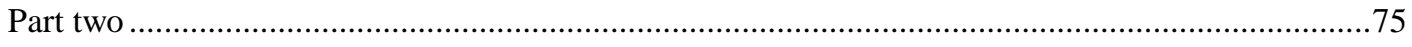

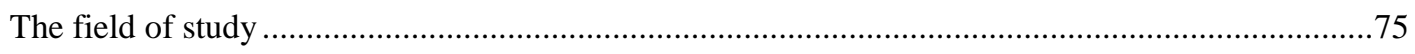

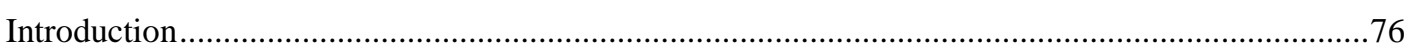

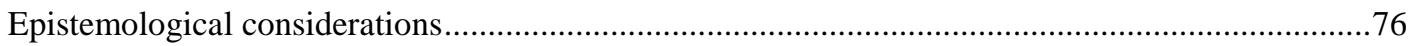

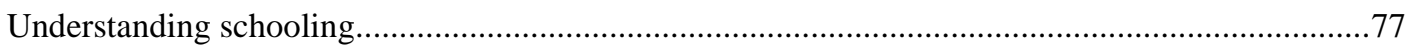

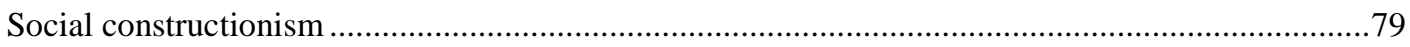

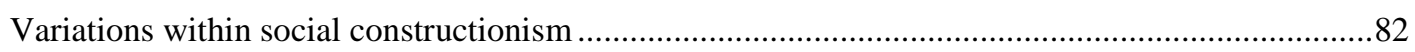

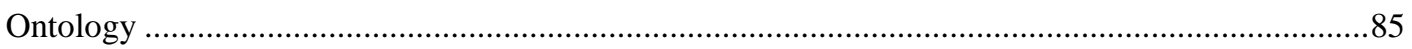

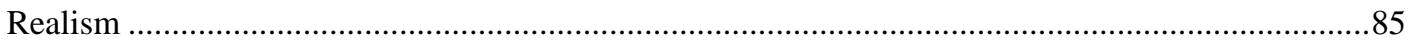

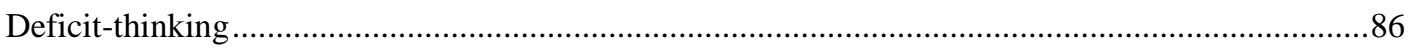

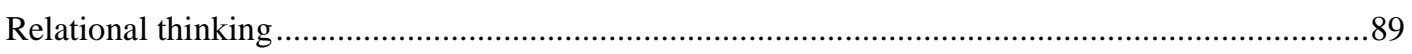

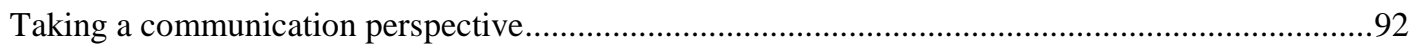

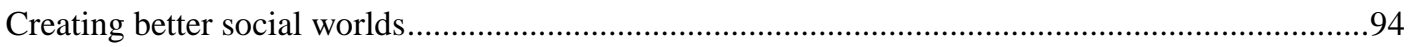

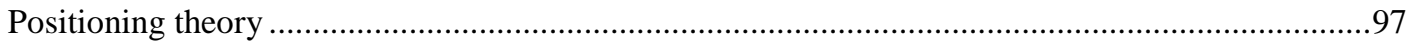

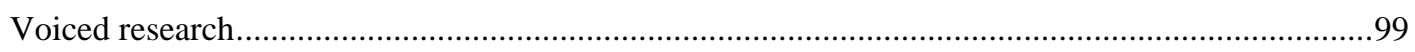

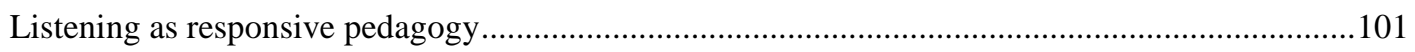

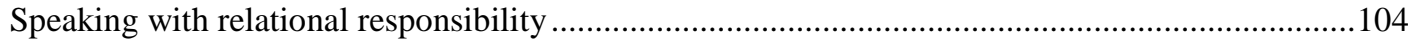

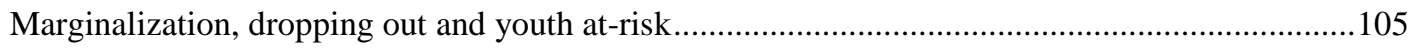

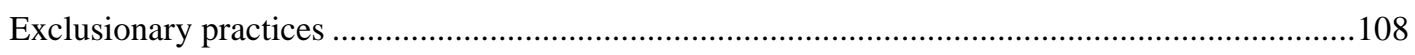

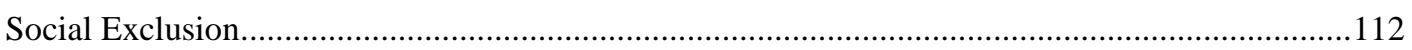

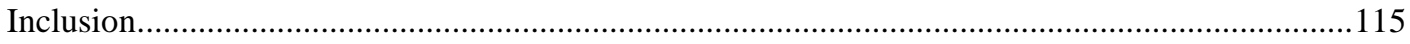

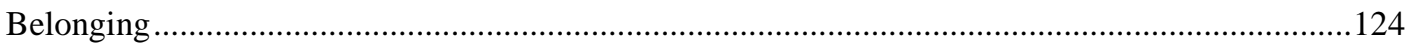

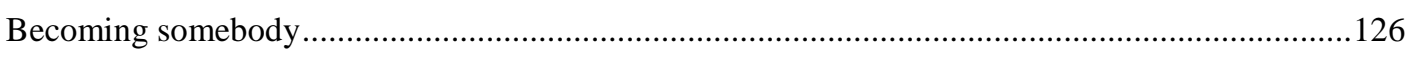

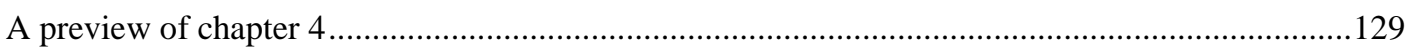

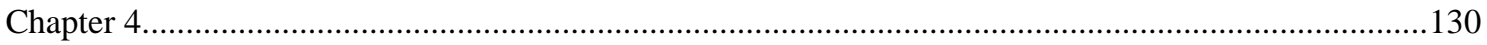

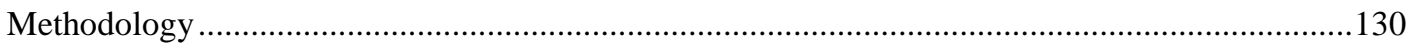


Research Methodology

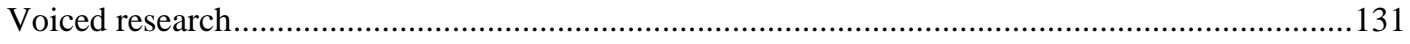

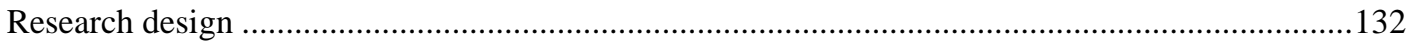

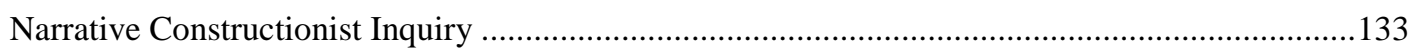

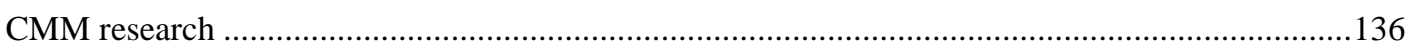

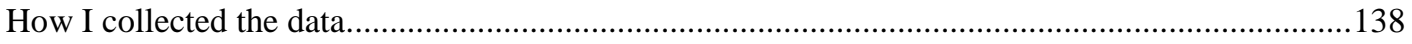

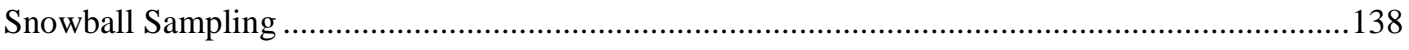

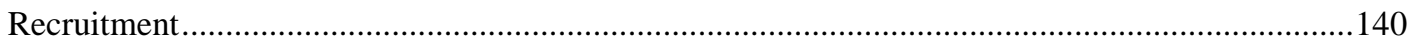

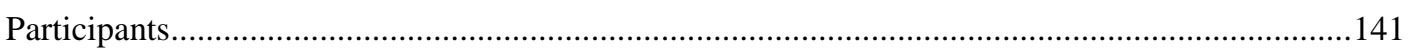

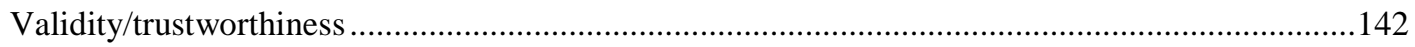

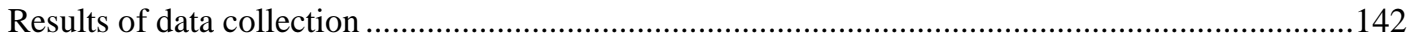

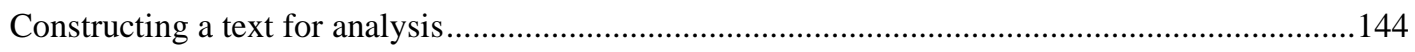

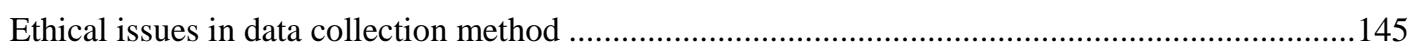

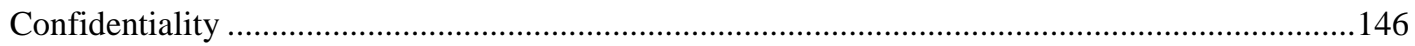

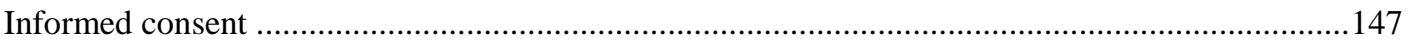

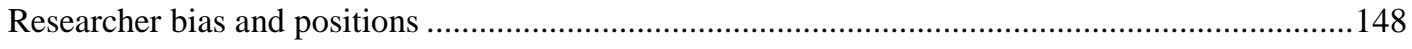

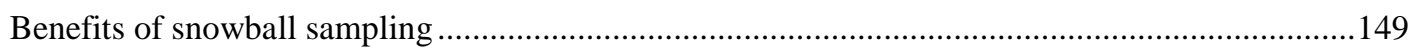

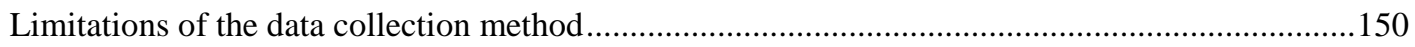

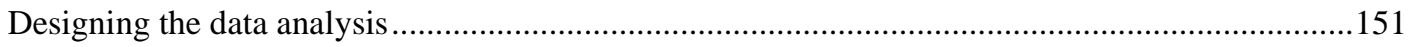

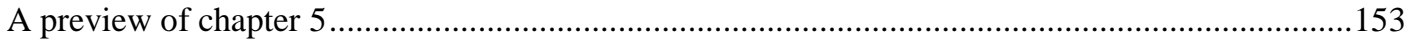

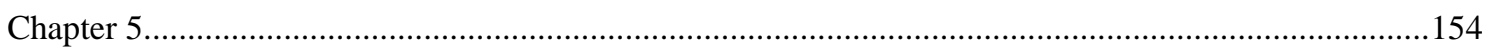

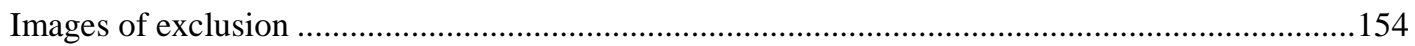

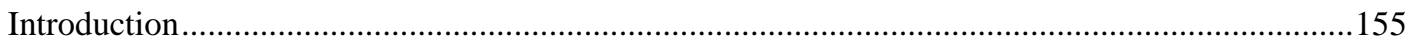

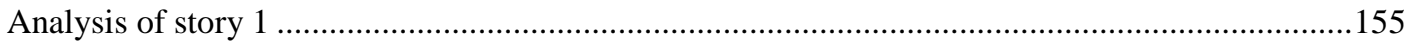

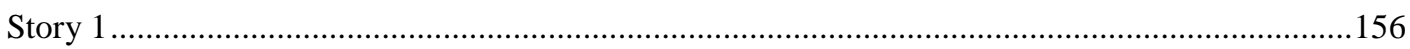

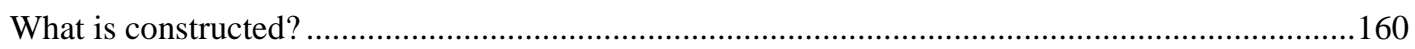

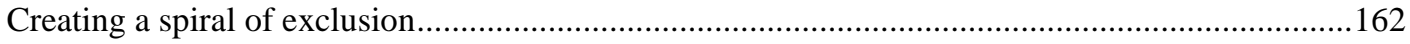

Moments that matter in exclusionary interactions ..........................................................................163

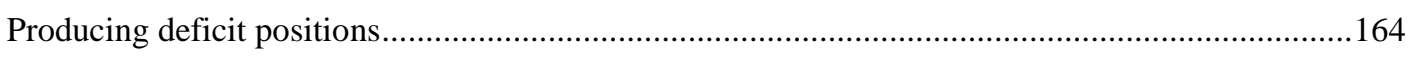

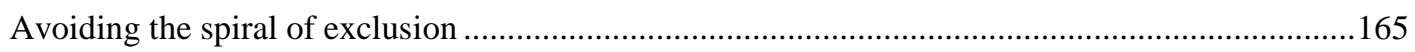

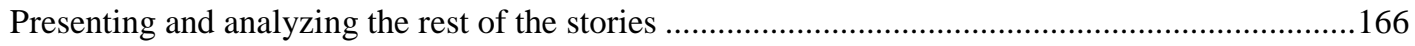

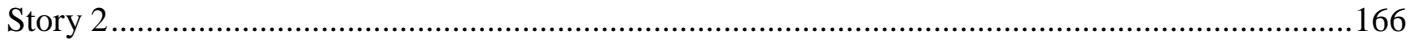

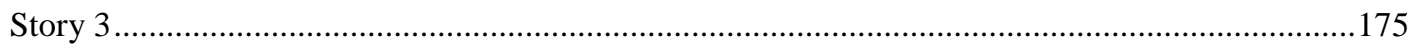

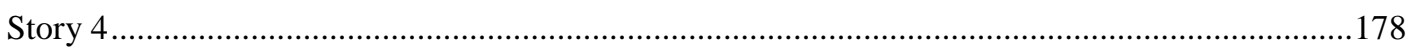

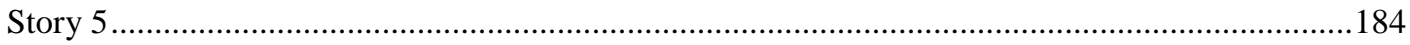

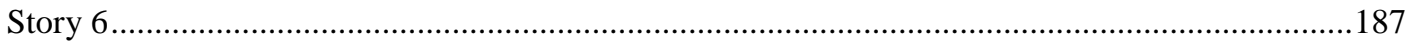


Story 7

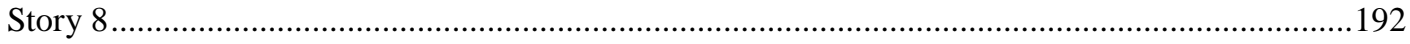

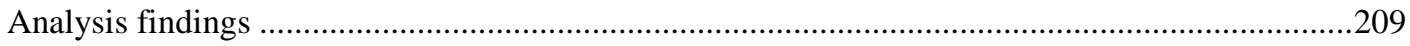

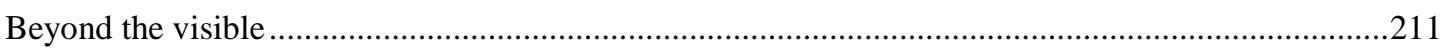

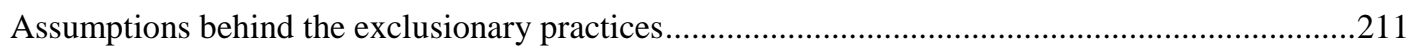

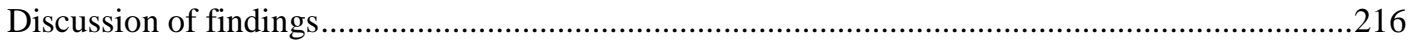

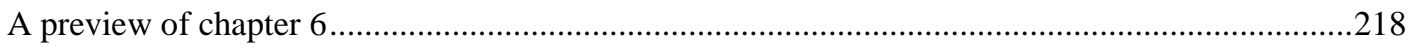

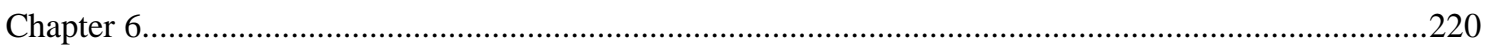

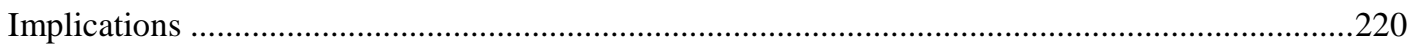

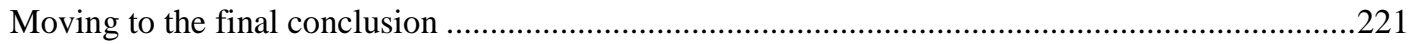

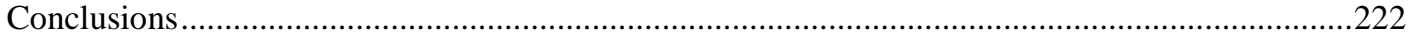

Producing, reproducing and repeating exclusionary practices .......................................................224

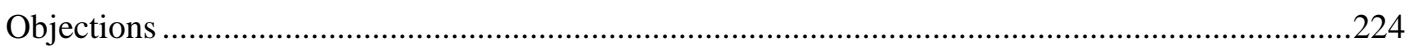

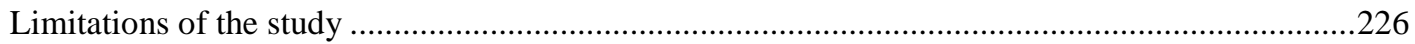

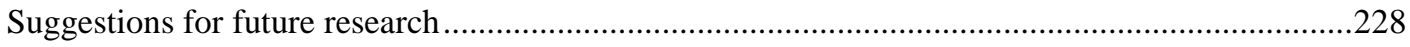

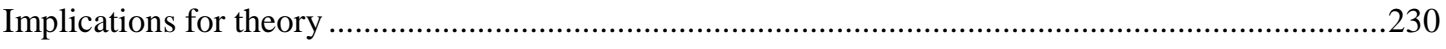

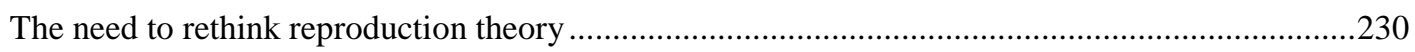

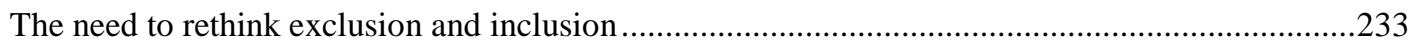

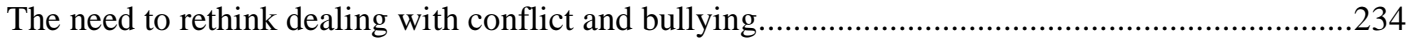

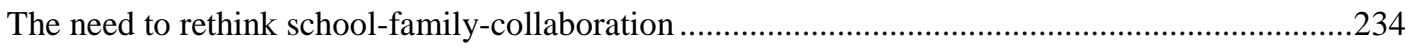

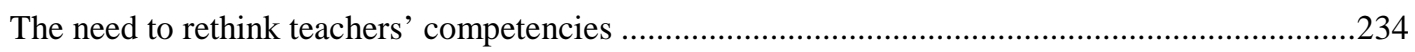

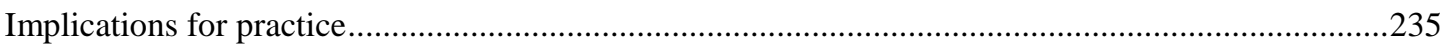

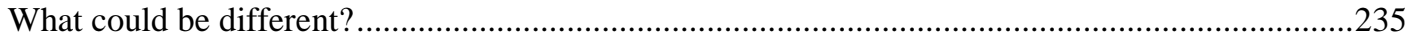

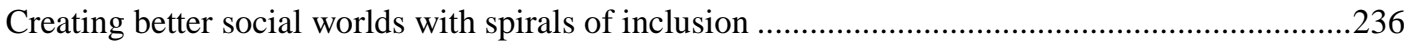

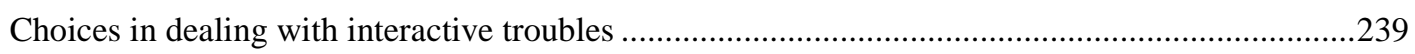

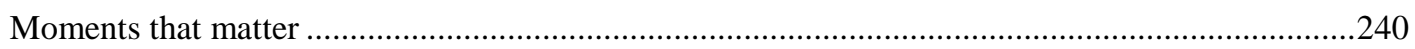

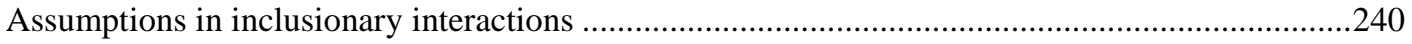

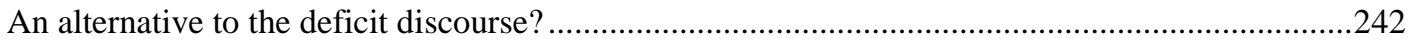

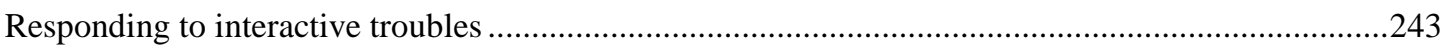

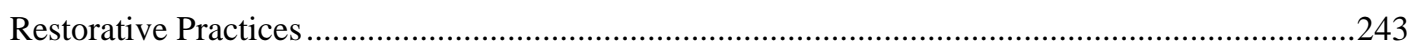

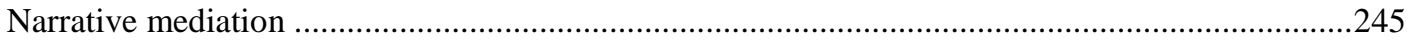

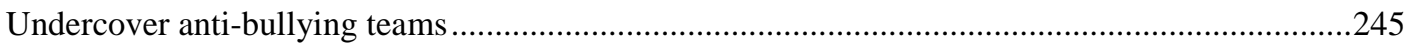

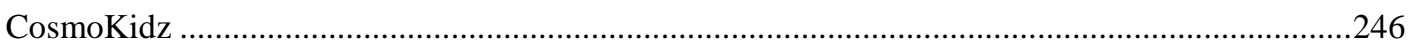

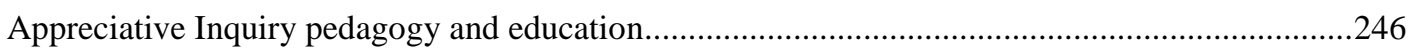

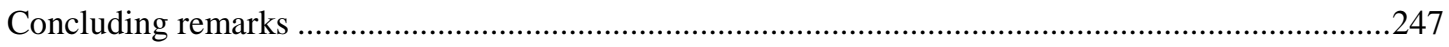

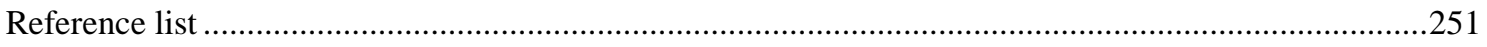




\section{Dedications}

I wish to dedicate this study to all the children and families who have had experiences with exclusionary processes in schools. Most likely they have not had the opportunities to share their stories and explain the pain and despair of their experiences. My dedications aim towards those children who have been met with disapproval, intolerance, misunderstandings, disrespect and humiliation in schools and not having had the power and the opportunities to speak up for themselves. As well as to the students who have fled from school, not having had the support, nor the concepts and language to explain and understand the powers of oppression on them, performed by the school system.

Furthermore, I dedicate this study to those parents who have felt distrust in themselves and their child when meeting with the school's descriptions of their child. Many of you still kept fighting against stigmatization (Fine \& Cammarota, 2008; Freeman, 2010) and still believing and having hopes for the future. The study is also dedicated those teachers, pedagogues and principals who had negative experiences in relation to dealing with interactive troubles in schools and felt the frustration of not being able to properly care for a student at risk of exclusion.

Finally, this study is dedicated to those teachers who fight against the structures of exclusion and succeed in reshaping the opportunities for students and families otherwise at risk of exclusion. Without you we would not have many positive images of successfully relating and learning from interactive troubles.

I hope this dissertation will find its way to all of you just mentioned and that by reading this dissertation it will give you new insights into the exclusionary processes around interactive troubles in schools. I hope you will find comfort and support in discovering that you are not alone with these experiences and that they happen not because of evil people intending to do harm, but due to the basic assumptions and ways of thinking related to culture and language within the school community - and most important, that this is changeable. 


\section{Acknowledgements}

My acknowledgements go in three directions. The first concerns the parents who I have engaged with in terms of doing this research. The second concerns my supervisor Professor John Winslade, and the third concerns my working partner and director, as well as my family.

I wish to acknowledge those families who have had the courage and willingness to share their stories with me. Without them, this dissertation was not possible. I wish to acknowledge the efforts from these parents who keep trying to establish a good relationship to their school, in spite of the negative positioning of their children. There are so many courageous, wise and caring parents out there fighting for their right to speak and for the right to speak on behalf of their child. My hopes are that these voices will be given a more legitimate and much larger role to play in dealing with interactive troubles in schools. I wish to acknowledge all those children who by their actions and stories are telling us about those everyday practices in schools that are producing exclusionary processes, marginalization and student frustration. Without these voices, we would never have been aware of the invisible social exclusion of students and their families in schools.

This dissertation is very much a result of the close cooperation between my supervisor Professor John Winslade and myself. I wish to pay a special attention to John's pivotal and profound insights in the creative powers of communication and how these powers structure relationships, events and identities. I feel the greatest appreciations for his continuous encouragements, advice, wonderful questions, and immensely important experiences, not only with the field of study, but with advising PhD students. This dissertation would not have been possible if it was not for this fruitful, respectful, energizing, empowering and productive relationship that we created.

I wish to acknowledge my working partner and director Gitte Haslebo, who stood by me in the process. Without her willingness to let me conduct this study, it would not have been possible. Together we found ways to balance publishing books and doing consultancy on the one hand and, for me, to find time to doing this study. Finally, I wish to acknowledge my husband and kids, for whom this three year process has been long, too. Without your patience and understanding, it would have been a very difficult task to complete the dissertation. I shall be looking forward to days of relaxation and fun with you without having to think about working on the dissertation.

As a final reflection, I wish to acknowledge all those teachers, pedagogues and principals who are aware of these phenomena and who strive towards more inclusive and fruitful ways of relating in situations of interactive troubles. Without all of you, new and better practices would hardly emerge. 


\section{Overview of figures}

$\begin{array}{lr}\text { Figure 1.1. The research hypothesis } & \text { p. } 28\end{array}$

Figure 2.1. Distribution of students' average in each indicator of wellbeing, $4^{\text {th }}-9^{\text {th }}$ class $\quad$ p. 45

$\begin{array}{lr}\text { Figure 3.1. } \mathrm{CMM} \text { and its conceptual cousins } & \text { p. } 93\end{array}$

$\begin{array}{lr}\text { Table 3.1. Inclusion and exclusion } & \text { p. } 119\end{array}$

$\begin{array}{lr}\text { Figure 4.1. A spiral analysis } & \text { p. } 152\end{array}$

$\begin{array}{ll}\text { Figure 5.1. The spiral of exclusion } & \text { p. } 163\end{array}$

$\begin{array}{ll}\text { Table 5.1. Moments that matter } & \text { p. } 164\end{array}$

$\begin{array}{ll}\text { Figure 5.2. When exclusion is not happening } 165 & \text { p. } 165\end{array}$

$\begin{array}{ll}\text { Table 6.1. Reproduction and production of social status } & \text { p. } 231\end{array}$

Table 6.2. Reproduction Theory and pattern breaking p. 232

$\begin{array}{lr}\text { Figure 6.1. The spiral of inclusion } & \text { p. } 238\end{array}$

Table 6.3. Different choices in exclusionary and inclusionary practices $\quad$ p. 239 



\section{Samenvatting/Abstract in Dutch}

Deze dissertatie stelt aan de orde de vraag of onze tradities met betrekking tot interactieve problemen in scholen ons nog wel goed dienen. In dit boek wordt verslag gedaan van onderzoek naar hoe uitsluitingsprocessen zich ontwikkelen --als gevolg van interactieve problemen zoals onrust, conflict en pesterijen-- waarbij allerlei families uiteindelijk van scholen uitgesloten worden. Deze studie begint met het toelichten van het probleem van uitsluiting in het algemeen, en specifiek met het aandragen van een contextueel overzicht van Deense scholen, waarbij in detail wordt getreden over schoolbeleid, en het refereren naar statistieken uit nationale metingen rondom problemen op school, het welzijn van studenten en het leren. Het verkent de denkwijzen en de micro processen in communicatie die school deskundigen gebruiken in interactie met studenten en ouders, en spitst zich toe op hoe die interacties bepaalde manieren van tekortsituaties genereren en regenereren. Het doel van dit boek is om buiten de traditionele reproductie theorie te treden en de micro precessen zichtbaar te maken waarmee mensen aan de kant worden gezet; gestigmatiseerd worden en/of het zwijgen opgelegd, terwijl ze het recht hebben om beter gehoord te worden.

De gehanteerde methodologie is er een van verwoording, gemengd met sociaalconstructivistisch denken, gecoördineerd management van betekenissen en kritisch onderzoek naar verhalende en redenerende positionering. De empirische gegevens bestaan uit acht korte verhalen die werden verzameld door middel van gesprekken met ouders die uitsluiting van een school hadden ervaren en gedwongen waren een ander school voor hun kind te vinden. De ouders die participeerden werden verworven via een 'snowball' steekproefmethode. Gedurende het vertellen van de korte verhalen aan de ouders veranderde hun positionering van 'gemarginaliseerde of gesnoerde stemmen' in competente en kundige personen die bijdroegen aan een belangrijk onderzoek. Waar het in dit onderzoek om gaat is het luisteren naar deze onderdrukte stemmen omdat ze belangrijke dingen te vertellen hebben waar we van moeten leren.

Door het analyseren van deze acht korte verhalen van uitsluitingsprocessen worden zes stappen in een uitsluitingsspiraal geïdentificeerd. Deze stappen zijn: 1. het verhaal zo brengen dat de student gezien wordt als het probleem, zonder een verkenning van de bredere context waarin een probleem optreed; 2. "bewijs" aandragen om zo de student min-of-meer in staat van beschuldiging te stellen; 3 . het positioneren van de ouders als zijnde mede problematisch; 4 . de student en de ouders het zwijgen opleggen en het 
devalueren van hun perspectieven; 5 . het uit de school proberen te weren van het probleem richting de ouders, en hen als familie opdragen om de verantwoordelijkheid te nemen voor het oplossen van het school-student probleem; 6 . de familie een ultimatum te stellen: accepteer de tekortsituatie en neem de verantwoordelijkheid om het probleem thuis op te lossen of vind een andere school.

Ook andere bevindingen suggereren dat conversaties die uitgaan van problematische individuele tekortkomingen processen van uitsluiting creëren. Deze typen conversaties kunnen leiden tot de uitsluiting van hele normale families van scholen. Soortgelijke praktijken voor het reageren op interactieve problemen op scholen hebben zich ontwikkeld binnen het algemene kader van modernistisch denken en in het bijzonder binnen een debat over tekortsituaties. Enkele basis uitgangspunten van de frequent door scholen gehanteerde probleem-oplossingsmethode kunnen worden geïdentificeerd: a) het idee dat een schooldeskundige een neutraal observator is; $b$ ) het idee dat studenten probleempersonen zijn als vast wordt gesteld dat ze betrokken zijn bij interactieve problemen; c) het idee dat ouders die geen "leerklare" student leveren probleemouders zijn; en d) het idee dat interactieve problemen op school door de ouders moet worden opgelost en dat die zich niet op het "bordje" van de school bevinden. Deze fundamentele ideeën worden in deze studie bekritiseerd door te wijzen op de negatieve constitutieve effecten die ze hebben op relaties en de opties voor actie. Bezien door de lens van het sociaal constructivisme worden deze ideeën gezien als ontoereikend en zelfs contraproductief. Ze gaan voorbij aan de morele plicht van degenen die studenten schoolt, m.n. als we daarbij als doel zien: om condities te scheppen teneinde elke student uit te doen laten groeien tot een evenwichtig volwassen persoon.

De theorie van gecoördineerd management van betekenissen legt zich toe op het scheppen van sociale werelden door interactie. Deze theorie wordt toegelicht en gebruikt om te verklaren hoe wat mensen doen en zeggen vorm geeft aan hun relationele posities en daaropvolgende gebeurtenissen, en om zichzelf niet alleen te begrenzen maar juist ook in te zetten via het scheppen van nieuwe mogelijkheden. De sociaal-constructivistische ideeën in dit onderzoek worden gebruikt als een theoretisch instrument, een praktisch instrument en een instrument voor onderzoek. Voor het doel van onderzoek wordt niet alleen het gecoördineerd managen van betekenissen, maar ook kritische 'narrative' en 'positioning' theorie aangepast om de aandacht te vestigen op de zich ontpoppende processen: met een nadruk op wat van-moment-tot-moment wordt 'gecreëerd'. Het gaat er niet zo zeer om om 
de momenten te observeren, maar om de daaropvolgende reflecties van deelnemers aan die momenten over wat die voor hen creëerden.

De analyse van gegevens vermijdt het construeren van mensen binnen een gegeven debat; in plaats daarvan ondersteunt het een concept van persoonlijk 'agency' dat is bereikt via een reactie op de wijze waarop een student of familie is gepositioneerd. Deze studie benadrukt de superioriteit van een zogenaamde relationele, ondersteunende en probleemoplossende denkwijze voor praktijken die interactieve problemen oplost in plaats van individuele personen de schuld geeft. De analyse van wat anders zou kunnen zijn maakt de problemen van de overheersende huidige benadering zichtbaar en faciliteert een theoretisch robuuste weergave van alternatieve handelswijzen.

\footnotetext{
Abstract

This dissertation questions whether or not our traditions of dealing with interactive troubles in schools are continuing to serve us well. It is a study of how exclusionary processes evolve as a result of dealing with interactive troubles, such as turmoil, conflicts, and bullying, whereby all kinds of families may be eventually excluded from schools. The study begins by outlining the problem of inclusion in general and providing an overview of the Danish school context specifically, going into details about school policies and referring to statistics from national measurements around school problems, student wellbeing and learning. It explores the kinds of thinking and communication micro-processes that school professionals use with students and parents, and focuses on how certain kinds of interactions produce and reproduce deficit-positions. Thus, it aims to go beyond traditional reproduction theory and make visible the micro-processes in interactions that marginalize, stigmatize and mute voices otherwise entitled to speak.

The methodology employed is one of voiced research blended with social constructionist thinking, coordinated management of meaning and critical inquiry into narrative and discursive positioning. The data consists of eight short stories that were collected through research conversations with parents that had experienced being excluded from a school and forced to find another school for their child. The participating parents were recruited through a snowball sampling method. Through the process of story-telling the parents' positioning changed from being 'marginalized or silenced voices' to being competent and knowledgeable contributors to an important research study. What this
} 
study is about is listening to these subjugated voices, because they have important things to tell that we need to learn from.

Through analyzing the eight short stories of exclusionary processes, six steps in an exclusionary spiral are identified. The steps are: 1 . contextualizing the student as the problem; 2. substantiating the problem story with further "evidence"; 3. positioning the parents as problematic; 4. silencing student and family voices and devaluing their perspectives; 5 . exporting the problem from the school into the family and passing the responsibility to the family to solve it at home; 6 . giving the family an ultimatum - either accept the deficit positioning and the responsibility for solving the problem at home, or find another school.

Findings suggest that problem-, individual- and deficit- based conversations create exclusionary processes from interactive troubles. These conversations can lead to middle class families being excluded from schools. Familiar practices for responding to interactive troubles in schools have developed within the general philosophical framework of modernist thought and especially within deficit discourse. Several basic assumptions of the problem-solving method can be identified: a) the idea of the school professional as a neutral observer; b) the idea of students as problematic persons if they are found to be involved in interactive troubles; c) the idea of parents who do not deliver "the learning-ready" student as problematic parents, $d$ ) and the idea that interactive troubles in school should be dealt with by families and are not the province of the school. In this study, these foundational concepts are critiqued by pointing to the negative constitutive effects they have on relationships and options for action. Further, through the lens of social constructionist thought they are found inadequate and even counterproductive. They fail to take account of the moral purpose of schooling, if we think of this purpose as creating the conditions for the becoming somebody of students.

The theory of coordinated management of meaning focuses on the creation of social worlds through interactions. This theory is outlined and used to explain how what people do and say structures relational positions and subsequent events and assigns or limits the possibility of agency. Social constructionist ideas are used in this study as a theoretical tool, a practical tool and a research tool. For the research purpose, coordinated management of meaning, critical narrative theory and positioning theory are adapted to include attention to the unfolding of processes with a focus on 'what is created' in the moment. Not by observing these moments, but as hearing participants' subsequent reflections on these moments and what it created for them. 
The analysis of the data avoids constructing people as determined within discourse and supports a conceptualization of personal agency as achieved through response to how a student or a family is positioned. The study establishes claims for relational, resource and resolution thinking as practices that address the problems of interactive troubles instead of blaming individuals. The analysis of what could be different makes further visible the problems found in current practice and enables a theoretically robust account to be given of an alternative practice. 
Chapter 1

\section{Introductory}




\section{What this dissertation is about}

In this project I am studying how students and parents are excluded from schools as a result of interactive troubles. Interactive troubles cover issues of conflict, bullying, hurts, misunderstandings and other relational or communicational disputes. By listening to parents, I investigate the process of communication that leads to the final exclusion, and try to determine what underlies the particular communication performed by the school professionals.

I have constructed a piece of research that amplifies the plural voices of students and parents who suffer from exclusionary processes in schools. For this purpose I have collected eight short stories through conversations and interviews with parents whose children, as well as themselves, have experienced stigmatization, marginalization and exclusion by schools. I want you to hear the colloquial - in some cases boastful and in others choked voices as constructors and agents of knowledge (Fine, 1994, p. 75). Voices of parents and students are often overheard, denied, neglected and oppressed. They have no legitimate audience to which to turn. But they are speaking. What becomes possible for them to tell us that we can hear and learn from? What can we learn if we listen carefully? What I show is that these voices bear evidence of processes in schools, where students and parents are excluded due to the positioning of them as deficient, as problematic (bad parents) and as unwilling to collaborate. It is important to ask how this happens? There are many ways of answering such a question. However, I will focus on the ways of thinking that create the positioning and the exclusionary process.

My foundational belief is that first we need to realize that exclusionary processes do take place in schools, and secondly to use that insight to actively and intentionally reshape the exclusionary practices into inclusionary ones. In order for school professionals to know what not to do and what to do instead, it is important to understand more about what drives the exclusionary processes that take place in every day interactions. Such knowledge can contribute to the development of inclusionary practices in schools that emphasize and appreciate the potential of every student and offer the best possible conditions for students to become wise, empathic, creative, responsible, democratic and curious both as children and later on as adults and citizens.

Even though focusing on exclusionary processes, this dissertation is also a contribution to questions about how to succeed with inclusion in schools. It offers inspiration on how to rethink the current idea of inclusion and the current practices in 
schools that unintentionally are exclusionary. I am thus endeavoring to offer a plausible explanation of why we have not yet come to solve the inclusion problem (Jørgensen, Blankenberg, Skall \& Schjerbeck, 2016). Since I believe we have been approaching this issue the wrong way, I am offering concrete suggestions how we might reconsider some specific, but widespread, everyday practices in schools. There is a need to reconsider the way we understand inclusion as integration of special children into general education to inclusion of all children into an inclusive learning community. The latter understanding is based on the legitimate right of all students to participate, to bring forth their voice and their experiences in daily school life - including situations of interactive troubles. It emphasizes inclusion as well as exclusion as created in communication and relationships that are continuously unfolding in various ways.

Furthermore, I suggest a way to succeed at creating inclusionary schools by changing the dominant way we think and the practices and processes that parents are invited into around situations of conflict. I wish to show how what happens in schools not only influences relationships, belonging, identities and the becoming somebody of students (Smyth \& Hattam, 2004; Graham, 2006; Pearce, 2011; Roman, 1997; Willis, 1977; Wexler, 1992) and their families, but how school professionals position families in deficit and at-risk positions that create exclusionary processes that ultimately give very few options for the affected families.

Skrtic (1995) argues how troubling it is that the inclusion debate largely follows the same pattern as the mainstreaming debate. As a form of naïve pragmatism it criticizes current special education models and tools "without explicitly criticizing the theories and assumptions that stand behind them" (p. 80). The need to re-conceptualize inclusion has at least two reasons. First, the current way is not working and we have still not solved the inclusion problem (Jørgensen et al., 2016), and second, recent research has shown that some of the premises of the current idea of inclusion and affiliated practices are outdated and far too simplistic because they are founded on a deterministic logic. This counts as established knowledge within reproduction theory as well as in dominant images of normality, traditional behavior management practices and practices in parent-school collaboration.

For decades, reproduction theory (Ejrnæs, 1999; 2004; 2011; Elsborg, Hansen \& Hansen, 1999; Giroux, 2006; Hattam \& Smyth, 2015) has investigated how social marginalization is passed on to the next generation, mainly explaining marginalization in terms of family background. This has led to practices in schools, where student behavior 
and relational problems are understood as reproductive issues, leading school professionals into investigating causes for school problems within the family. Unproductively, families thereby are in danger of being distrusted, blamed and assigned responsibility for what happens in schools.

However, recent research on reproduction theory has shown that half of marginalized youth are brought up in middle class families with no indicators of at-risk or social marginalization (Benjaminsen, Andrade, Andersen, Enemark \& Birkelund, 2015). This challenges the traditional causal logic within this field and leads to a showdown with the traditional and dominant view that reasons for marginalization are to be found in the families of students. When marginalization cannot be explained by family background, it is necessary to look elsewhere for explanations, and Benjaminsen et al. suggest looking at marginalizing structures in public institutions such as daycare and schools. Even though they do not go further than to state that social marginalization cannot be explained by family background and that research needs to look at exclusionary processes in schools and other institutions, they pave the way for talking about exclusionary processes in schools.

Comprehensive research has shown how images of normality have narrowed to an extent where all children are potentially diagnosed or affected by special needs (Brinkmann, 2010; Fisker, 2013; Graham \& Slee, 2006b; Hertz, 2010; Holst, 2007; Rasmussen, 2015). To counter this harmful development, the idea that all children are special was introduced, but paradoxically it has not led to a broader understanding of normality (Alenkær, 2012; Graham, 2006). On the contrary, the possible diagnoses and labels for children have multiplied and more and more children are perceived as 'not normal'. It has become normal for school professionals to consider what is wrong with a child and how the situation can be explained by individual characteristics of the child (Graham, 2006; Klinge, 2016; Nielsen, 2012; Nordahl, 2008). Earlier on, psychologists and psychiatrists discussed whether a child was in need of a diagnosis, but now this is common talk amongst teachers as well. This development in teacher focus has happened in parallel with developments in diagnosing and medicating school children not seen just ten years ago. When the concept of normality is very narrow, the range of diagnoses broadens and the affiliated deficitthinking becomes very widespread. As a result, more students are in danger of being understood and treated as not normal. Therefore, there is a need to think differently and avoid the trap of problematizing, individualizing and dehumanizing students.

Research on behavior management practices and support initiatives in schools has shown that these are far too individualistic (Bronwyn, 2008; Haslebo \& Lund, 2014; Nordahl, 
2008; Tetler, 2007; Tetler, 2011; Tetler, Hedegaard-Sørensen, Emtoft \& Ulvseth, 2012), too problem-focused (Alenkær, 2007; Graham, 2006; Haslebo \& Lund, 2014; Mæland \& Hauger, 2011; Nordahl, 2008) and insufficient in engaging students and restoring their belonging to the class community (Mæland \& Hauger, 2011; Smyth \& Hattam, 2004; Roman, 1996; Winslade \& Williams, 2012). Despite this, the use of behavior management practices, classroom management and disciplinary approaches are multiplying, supported by guides from the Danish Ministry of Education. This is seen in zero-tolerance policies, anti-bullying strategies, consequence pedagogy and tools for managing student behavior. In response, new relational, restorative and engaging approaches are developing and already proving their worth. What makes the difference, it seems, is a different epistemological basis for practice.

Research (Dannesboe, Kryger, Palludan \& Ravn, 2010; Freeman, 2010; Højholt, 2005; Madsen, 2008) and discourse analyses of school-family collaboration have shown how the conditions for collaboration are deprived and destined to fail (Knudsen, 2008; 2010). These studies bring into question current practices and show how parents are met with negative expectations, and not given many opportunities to influence the wellbeing of their child in school (Knudsen, 2010). Despite this, it is becoming best practice to involve and engage parents more and more in schooling, not only about academic and social issues around their own child, but about the class community itself. Good intentions notwithstanding, the discourses available position parents in passive and deficit positions with little legitimate power. The set-up is made for conflict. Therefore, there is a need to reconsider the relationship between teachers and parents and find ways in which parents can be invited into collaboration that is responsive to their perspectives.

\section{Not only a Danish issue}

This is a Danish study conducted in the period 2013-2016 and thus it may introduce phenomena that are mainly local. However, my reading of both national and international research literature suggests that the issues addressed in this dissertation are much more widespread. Let me nevertheless share some characteristics of the Danish public school system. In Danish, the name for public schools is folkeskole, which translates to school for the people (the nation). All children from seven to fifteen years are enrolled in primary school, the vast majority in public schools. $98 \%$ of all fifteen year olds and $68 \%$ of the nineteen year olds are in the education system. Among all fifteen to nineteen year olds 85 
$\%$ are in the education system (Ottosen, Andersen, Nielsen, Lausten \& Stage, 2010). The Danish Public School system is publicly funded through taxes and has for centuries provided the foundational basis for a free, democratic welfare system. Public schools are legally obliged to facilitate social mobility and decrease negative social reproduction. All children are legitimately entitled to attend public schools. Only $1.5 \%$ of the students between seven and fifteen years attend public schools for special education. A large percentage of school professionals are educated and trained teachers. To achieve the bachelor of teaching takes four years of study at the university college for teacher training. The Danish school system is based on strong values such as unity, equity, freedom of speech, democracy and inclusion and the value of social cohesion. This might explain why social exclusion in schools is a rather neglected topic in Danish research.

Social exclusion and marginalization in schools are related to issues of dropping out and educational and occupational marginalization later in life. As the Australian educational researchers Smyth and Hattam (2004) point out, dropping out of school or not completing school has been the subject of conjecture and contestation for more than three decades in many countries. Smyth \& Hattam argue that young students failing to meet the demands of teachers is closely connected to issues of being stigmatized, marginalized and excluded. These issues are global, pervasive and far-reaching in their implications, as well as poorly understood. Hence, the issues are often mischievously constructed to serve certain interests while denying others (Smyth \& Hattam, 2004).

The title of Smyth and Hattam's (2004) book, Dropping out, drifting off, or being excluded-Becoming somebody without school, indicates that we are both dealing with exclusion as a result (the final dropping out or exclusion of a student) and a process (involving stigmatization and marginalization). Such a distinction has previously been largely overlooked by research, whilst mainly focusing on dropping out as individually determined.

\section{To open a space of enunciation}

In this thesis, I present a series of stories showing how students and families are positioned in silence by school professionals with presumably good intentions. Along with Smyth and Hattam, I agree there seems to be a need to open a space of enunciation for students who are not complying in schools - as well as for their parents. It is not only that they are silenced, but that, even when they do speak, they cannot be heard (Fine, 1989; Roman, 1996). 
An even bigger challenge, however, is to start the conversation about changing school cultures by strengthening relational thinking and practices. To do so, school cultures would need to be designed to foster listening, inviting, enunciation, asking questions, using an appreciative language and taking on the ethical responsibility for every student's becoming somebody. What I am suggesting is that every event and every conversation in school contains potential for students to become somebody and that it is the schools' finest task to give place for such potential, help bring it forth, name it and celebrate it.

Smyth \& Hattam talk about the phenomenon of "mis-communication at the cultural level of the relationship between the lifeworlds of students and teachers" and call this interactive trouble (2004, p. 169). They explain that instances of interactive trouble occur when young people are prevented from fully participating in the school curriculum, because of their failure to understand the cues of the teacher, while teachers, on the other hand, are seemingly unable to make sense of students' talk.

While focusing on the unintended, negative, constitutive impacts of everyday communication in schools, I find interactive trouble a legitimate and useful description (naming) of the context. It might cover some of what is going on in the eight short stories presented in this study, where there is both miscommunication and interactive trouble. But there is more to it. The problem is not the interactive trouble itself, but the basic assumptions that lead to interactive trouble. In particular individualistic thinking leads to practices and communication with negative implications, effects and impacts on relationships and student becoming, in the process producing exclusionary outcomes.

\section{Inviting parents' perspectives into the conversation}

Parents' perspectives on interactive troubles have not been much researched (Freeman, 2010; Madsen, 2008), which is peculiar since school-family collaboration has been found to have great significance for students' learning (Epstein, 2001; Hattie, 2008; Nordahl, 2008; Krogh \& Smidt, 2015). In Denmark there have been traditions of school-family collaboration since the 1930s when the Parents' Union was established and the collaboration has taken many different shapes over the years. Recently it has been acknowledged that the field of school-family collaboration is ambiguous and full of dilemmas (Freeman, 2010; Knudsen, 2008; 2010). When it comes to exclusionary processes and interactive troubles, parents' voices seem relatively absent from the conversation. I wish to invite these voices into the discourse. I have encountered not only my own 
experiences of being voiceless and powerless in regard to difficulties around my children's school life, but have discovered that many other parents experience the same phenomena and have had nowhere to turn to share their stories. I am satisfied that I provided a context for these voices and stories to be heard. Inviting parents' perspectives on students in trouble at school not only legitimizes those perspectives, but also points to the importance of listening more carefully to what they have to say. When not invited into the dialogue, these voices either remain mute or become shrill. Given a legitimate place in the conversation, however, these voices provide valuable input into school practices (Smyth \& Hattam, 2015).

The positioning effects of communication have to do with the use of language. It does make a difference if a student is talked about as a culprit or talked to as struggling to find ways to make friends. The first is an objective and universal description that functions as a negative identity conclusion (Winslade \& Monk, 2000; White, 1989) and the latter is a way to try to describe the hopes and actions from the student's perspective (Davies \& Harré, 1990; Hertz, 2010; McAdam \& Lang, 2010). It does matter to parents how school professionals talk about and to their child. Naming, labeling, the words chosen and the utterances exchanged matter profoundly and affect the quality of collaboration and relating between teachers, students and parents - but it is seldom given much ethical consideration in every day communication, especially concerning interactive troubles when emotions run high.

Concerns about the moral purpose of education contain the seeds of a vibrant and ethical exploration of school practices, where effects and impacts of teachers' actions, words, and practices are compared and held up to students' actual experiences and possibilities of becoming somebody. Educational researchers and scholars have addressed questions about the moral purpose of education in different ways over time, but as the world becomes more and more complex, highspeed and culturally blended, the debate has intensified. Fullan (2003) as well as many others (Barber, Mourshed \& Chijioke, 2010; Hattie, 2008; Biesta, 2011) point out that successful school systems, where all students learn and thrive at their best, need to take into account the moral purposes of their existence.

The best case for public education has always been that it is a common good. Everyone, ultimately, has a stake in the caliber of schools, and education is everyone's business. The quality of the public education system relates directly to the quality of life that people enjoy (whether as parents, employers, or citizens), 
with a strong public education system as the cornerstone of a civil, prosperous, and democratic society. As the main institution for fostering social cohesion in an increasingly diverse society, publicly funded schools must serve all children, not simply those with the loudest and most powerful advocates

(Fullan, 2003, p. 3)

I have now outlined the field of study, named the problem, and presented my research topic. To be precise, I will examine processes of exclusion in school-family relations and how these exclusionary processes are connected to particular ways of thinking and communicating (to be described in chapter 3). Educational scholar Roman (1996) says that the mischievous construction of the problem of social exclusion has to do with the missing presence of youth themselves as speakers with political legitimacy around issues affecting conditions of their existence, schooling being among the most prominent of these. However, as Roman argues, what is crucially important is the calling into question of the dominant constructions by thinking against the grain, which is to say developing the epistemological, methodological and political stance to alter, as well as challenge, dominant discourses that "naturalize the spectacle of youth at risk" (Roman, 1996, p. 2). What Roman points out is that there is a need to do more than merely include students at the table, since this will not necessarily resolve the crisis of representation raised by the issue of their structurally disenfranchised, trivialized or silenced voices. Danish research has proved likewise. Even though students attend school-family conversations, they are rarely given a voice (Dannesboe et al., 2012; Madsen, 2008; Knudsen, 2008). The discourses that Roman refers to are working as lines of force (Winslade, 2009) on the interpretations and meaning making that young students experience in processes of exclusion. As I understand Roman, this means that students have very little power to reject and avoid the negative positioning offered by the dominating deficit discourses. My point is that this counts for parents as well. I wish to make it possible for them to speak up and be listened to. In addition I wish to question and explore the opaque processes in communication that lead to stigmatization, marginalization and exclusion, and to explore the ways of thinking that govern these processes. It is my conviction that it is possible to change and transform school cultures to enable students to become somebody in dignity.

\section{Images of exclusion}


It is time to introduce the voices of a family that experienced exclusionary processes in relation to a school. This first story stems from a mother's account of a meeting at her son's school, who at the time was in the sixth grade in the Spring of 2013. For two years the family had suffered from a complicated and painful collaboration with the school. Issues around nagging, diminishing language, bullying and disrespect among students, as well as among teachers toward students, made school life difficult. In periods, the family found that they had not much energy left for much else. In trying to restore the relationship with the teachers and the principal, the family "negotiated" for months, while suffering from the rejections of their attempts to better the cooperation. Negotiation is put in quotation marks, since the possibility for negotiation in fact seemed out of question in that period. What they fought against was the school's criticism and negative descriptions of their child. The family felt that they did not have a say on these issues, and were never really listened to. However, as the story shows, the family also fought for something, namely for the school to take responsibility, to help out and to engage in a reciprocal and respectful collaborative relationship. The story is named $A$ student is silenced and is just one out of several offered by the family.

\section{Story 1}

A student is silenced

"I feared this meeting. Even though I had made an effort to try to co-create with the school manager a shared vision of the content and hopes for the outcome of the meeting, I had a feeling that they had something to bring up that they had not been quite honest about.

My husband, son and I arrived at the school. Present were the school manager and three teachers. We knew that one of the teachers might attend the meeting, as we had asked for him but it was quite surprising that all three of them were there.

I looked at my son. He looked stunned. My husband had a stone face. So did the teachers. I felt crushed by the responsibility of making this a good meeting, where my son could tell his story and where we all could co-create an appreciative inquiry into the different actions that the school could initiate to help the group of boys, who were not getting along very well.

As the school manager introduced the meeting by setting a totally different context than we had agreed on, my heart crimped and I felt sick. While listening to the stream of words: problematic, strange behavior, this person said, that person said, your son, blah blah, I sweat and froze and my throat turned dry.

My son raised his hand letting us all know, that he had something to say. He was ignored. The Principal kept talking. 
I was shocked. What were they thinking? How could they ignore his wish to say something? I could tell by the look in his eyes that his attention was disturbed and he disappeared into his own thoughts.

One of the teachers took over and talked and talked. He lined up all the problematic actions that the boys had done, including the problematic things that our son had done. I tried to find a breathing pause in his stream of words, but there was none. So I interrupted him by saying that we had come to let our son tell his story of being bullied and that he had been very patient and that I felt it would be a good thing if he could tell his story now.

They all looked at my son, who then said that he had now forgotten what it was that he wished to say.

The school manager quickly replied, "If it was important, you would have remembered it, don't you think?"

Then the teacher who had already been speaking for about fifteen minutes continued. Next, one of the other teachers took over and started talking of his perspective on the problems with the boys, including our son.

It was like being forced into a dark hole. My husband and I tried a couple of times to change the context and the focus of the conversation, but with not much luck.

At a certain point, the manager said, that it now was time for the adults to talk 'adult-talk', so it would be best, if my son left the room. My son was very surprised, because he had not yet had the chance to tell his story and he had not been asked any questions. I helped him to the door, whispering that it would not take long and that he might go to the library to play or read.

When I sat down again, I felt so ashamed. I looked at the school Principal. He looked me in the eyes and then said that they felt we ought to know what our son had said about us as parents. I held my breath. He continued, "Your son says that he sleeps with you, his mom..."

All turned silent... I cried, "What? What are you saying? What??" and then broke down in tears.

I said; "Who heard my son saying that?"

The manager told that some teachers had heard some younger students talking about my son having said so.

I asked, "Which teachers? Which students?"

He couldn't say, because he did not know.

Then I asked, "What kind of knowledge is this and for what purpose is it useful, in your eyes?"

He did not answer. He said, "We just wanted you to know how your son behaves at school and why things have been very difficult for us."

The meeting ended, but the conversation with the principal did not. We continued the conversation through telephone and emails. In a telephone conversation the next day, I asked, while feeling very angry: "If you consider this as solid knowledge, it must urge you to take action. Sexual 
abuse or sexual activity amongst family members is illegal and it is your responsibility to inform the social authorities. If you consider this as evil gossip or loose rumors, you have another problem that must urge you to take action, as I see it. Both the younger students and the teachers, and now the four of you, are engaged in telling horrible things and stories about our son and us. This confirms our experiences of our son being bullied and mocked. Even by teachers spreading evil gossip. How did you expect us to react to this?"

He could not answer, but agreed that they might have had misjudged the conversation.

I said that at that moment I could not make any more meaning out of this, and that the school manager and the teachers had completely lost track of professional handling, thinking and judgments. I suggested that they had just now demonstrated why my son feels so awful at school and demonstrated too how they themselves had played an important part in this situation.

He did not argue, but kept silent.

I continued and said that I was most disappointed, shocked and angry - and that I expected them to investigate which teachers had told them about this, and which younger students were saying so. Secondly, I told them, that I expected the school to initiate a thorough recovery process with the group of boys, including my son, who had been in conflict, and that it required a well thought through plan of action, and that the different teachers, the manager, and the school counselor unit was going to take such action.

All this was said, while crying unstoppably.

Reflecting back on the meeting, I remember the female teacher being very sad and ashamed at the meeting, and she later apologized through a mutual friend for not having stopped this conversation. She had struggled to not start crying herself, our mutual friend explained me. The main teacher, with whom we had been collaborating closely and well, was too confused by what was going on - and could not find words.

The third teacher, who worked as the conflict manager at the school and was also part of the counselor unit, and the principal himself stayed in the position of attack/accusation/defense, but I could tell, that they were not proud of the situation either and could not find any professional arguments, which only made it worse in my perspective.

On our way out, the manager said something about not being proud of this and admitting that he should have taken action months ago in terms of helping the group of boys and especially our son. I did not accept this half-felt apology. I wanted to see action.

Later on, it came forth, that no one amongst the teachers had either heard or told 'about our son saying so', but that it was the conflict manager who had overheard and seemingly misunderstood a conversation between two of his colleagues, and based on this, had informed the school principal according to his understanding of this being a serious matter.

What the two colleagues had been talking about was the language that students use and the influence slang, and especially American slang, had on the communication amongst students. Eg.'You motherfucker', 'Your mother is a bitch and a whore', and things like that. Children at this age seldom 
know what these words mean or how to translate them into Danish phrases. The two teachers were referring to a conversation they had overheard between a group of students, including some younger students and my son, discussing what 'You motherfucker!' means and in what contexts it made sense to use it - from a child's perspective."

Overtly, this story reveals a most unpleasant meeting and depicts many problems in the relationship and communication. Sharing it at this early point is intended to invite you to listen to parents' voices. Using parents' stories like this one raises some ethical questions. The stories are personal, quite delicate and unpleasant to recount for the families. But they are much more than that. They bear witness to profoundly negative experiences, and serve as powerful invitations to different audiences into the sacred and silent sphere of students' and parents' experiences at school. Together with the stories in chapter 5, this example belongs to the category of stories not told anywhere and, therefore, not known to the public. These stories center around parents' experiences of being muted, oppressed and humiliated, students being put down and families marginalized, stigmatized, accused and condemned not by people with malicious intent, but by school professionals wanting to do their best. Despite this, what is done in the stories feels utterly unfair to the families. A recurrent feature is the urge to convince families to understand "the way things really are", meaning the way the school professionals found the students "to really be". In focusing in this way, they create social worlds. Sadness is produced along with frustration, despair, loss of trust, and broken relationships.

\section{Becoming Somebody}

The story is an excellent example of positioning by narrative plots and of how conversations between school professionals and families contain invitations to adopt certain positions from which to speak. Positioning refers to the way positions are offered to people in interactions. Davies and Harré (1990) talk about language as speaking us into existence and constituting our personhood. What is said holds the power of putting others into specific positions. In this story the student is positioned in various negative and unworthy ways and is not even permitted to speak. He wishes to speak from the position as a victim of bullying, but is rejected and required to maintain silent. Instead he is offered the position as a perverted, misbehaving student. His voice and perspectives are not invited into 
negotiation of this definition of him. When unchallenged and unsuccessfully refuted, it becomes the reality that is acted upon.

I wonder what might be possible if relational thinking and relational approaches were actualized instead at this particular meeting. This is most interesting both in regards to what relationships and outcomes would have been possible and what positions the school professionals could have offered the student. And I wonder how many families have similar experiences.

This latter question led me to a larger study among my personal network of families and friends in my local area. I made an eerie discovery. No less than fourteen families in my closest network had suffered similar experiences that had either led to their children being expelled from school or the families themselves had felt no other option than to move their child to other schools. How did these exclusionary processes take place? What causes them to happen? What in the communication makes the processes exclusionary? This led me to a field of research, namely the invisible social exclusion of students and families in schools.

Schools are important sites of socio-cultural identity production for youth (Smyth \& Hattam, 2004) and, given what is going on in the story just presented, schools hold a huge responsibility for the kind of identity they offer students. In this case, the school was producing a very negative identity conclusion. The mother reacted with sadness and despair. She cried and would not accept this positioning of her son. She knew her son to be a kind, caring, curious, energetic and creative person and she was certain that he would not have made stories about this topic, nor told lies about it. She felt she had to fight for justice and for justification for her son. Fine (1990) puts it this way: "Perhaps no field surpasses public education as the space into which public anxieties, terrors, and 'pathologies' are so routinely showered, only to be transformed into public policies of what must be done to save us from them" (p. 55, emphases in original). In the word us, Fine refers to society and the 'moral' adults while them refers to immoral youth.

Communication theorist, Pearce, raises important questions about the process of production:

What are we making together?

How are we making this together?

Who are we becoming as we make this?

How do we make better social worlds?

(Pearce, 2007, p. 60) 
Regardless of worldviews and perspectives, these questions are pivotal and can serve as a guideline for most actions and conversations in schools. Taking these ethical reflections into account, it becomes an obligation to pursue the constitutive effects and impacts of conversations, utterances, dialogues and even ways of thinking. How can school professionals create conversations and situations where students (and families) can become somebody skilled, responsible and important contributing persons, instead of being demonized and silenced? How can school professionals position students and families in such ways that connect with the (moral) purpose of education with its aim of educating upcoming generations to be skilled, responsible and contributing citizens in a free, democratic society? What ways of thinking might be helpful and what ways of thinking might be counterproductive? One way to get a richer understanding is to examine the ways of thinking that are enacted and ruling in situations like those described above.

For school professionals in the story, the attention is directed to the point at which they 'fix' the image of the student, as though the student and his actions are fully separable from the teachers themselves, the system and context. They do not appear to see the exclusionary processes created by their communication as they actualize lines of force that ultimately mute the student and position him as not worthy. In some ways, they seem blind to these phenomena. How would the meeting have turned out, we might ask, had they acted in a caring, empathic, inquiry-based and appreciative way in meeting this student who is struggling with experiences of bullying and sadness in school?

\section{Social and personal location}

My intent is to develop a new reading of what is happening in schools - a reading that demands careful contemplation of what schools are "up to". Having said that, I also know that we read the word and the world "through a set of assumptions, socially shared and often unconscious, that frame knowledge and our relationship to it" (MacPherson \& Fine, 1995, p. 185). Therefore, I hold my own biases in careful regard.

Reed and Procter (1995) operate with three research positions; the outsider, the hybrid, and the insider, which they see as a continuum from being completely unknown in the area to be an integral part of it. The hybrid position is defined as a practitioner who studies other practitioners' practice in a context that is unknown to her, and/or where her official job is part-time practitioner and part-time researcher. The insider position is a practitioner doing research in her own organization and on her own or her colleagues' 
practices. The outsider position is the completely external researcher role. I find myself primarily in an insider position, which is supported by the fact that my goal is precisely to examine a practice that I myself take part in in order to solve a problem in practice and contribute to professional knowledge. The premise in a study like this is that it is situated and positioned in a particular way in relation to its study context and that my positioning is crucial to the study. The complexity of the research position will challenge my ability to reflect on the significance of my own position for the study. I will try to explain how.

During my years as a school teacher, I have seen how students struggle to be part of their class community and how a teacher might make a difference, such that these struggles either fail or succeed. Teaching both in primary and secondary education, I have come to learn that strong relationships with peers and teachers play a crucial part in student learning and thriving, no matter what age and subject. In special education, I have worked with students labeled at-risk and cognitively-disabled. I have seen how these students find ways to learn and thrive when engaged in careful interactions with teachers and with each other. I have also seen students explode in frustration and despair when met with aggression, demands, critique and rejection. I have seen violent student behavior towards teachers and principals as well as the other way around. It has filled me with fear and sadness each time a child hurts himself. I was puzzled by the tendency of professionals to turn to deficit descriptions of the individual student to explain what causes a problem. I have felt sad about the state of the art in many classrooms when dealing with interactive troubles, where scolding and aggressive teacher behavior was just part of the job.

However, my interest in this topic started due to my own experiences of feeling marginalized and blamed as a mother in relation to my children's school around interactive troubles. Alongside my own struggles, I was involved in other families' interactive troubles as well, both as just another parent in the class community, or at school meetings, or as supporting and listening to frustrated parents in more private conversations. Issues of bullying, deviant student behavior, failed behavior-management approaches and painful destructive collaboration with the school were all related to my experience. During the years of my children's early schooling, I discovered how students from my children's classes left school after having had a period of time - mostly up to a couple of years around conflicts in the class or between parents and the school. Most of those children left to start at new schools, but not all. Mostly they moved after having fought to restore their relationship with the school. A few stayed and suffered quietly, but then left later on and a few never went back to school again, and are now enrolled in very specific public services. 
More cases of exclusion came to my knowledge, as I tried to understand and maintain a constructive collaboration with my children's teachers and the principals in two specific schools.

It is important to state that my children have also had wonderful, skilled, enthusiastic and positive teachers, from whom they have learned immensely. As a family, we have had the joy and pleasure of being invited into good relationships and a prosperous collaboration. But we have also experienced the pain and frustration of being stigmatized and put down by a few teachers, who had the power to position our children and us in relationships that negatively dominated the whole school-family relationship.

As parents to three children in the Danish school system, my husband and I have many experiences with both inclusionary and exclusionary processes from everyday school life and from a broad variety of different conversations with school professionals. Many of those still stir up strong feelings, some positive and others negative. As a parent you give your most precious family members to others in the trust that these professionals will regard their job with the highest moral consideration. We have engaged in e-dialogues via the school intranet concerning students' failure to thrive, and have attended parent meetings around conflicts concerning interactive troubles. We have participated in conversations regarding our own children. We have spent time on school-home collaboration, both in regard to our own situation and the situations of other parents. Often we have found ourselves in hopeless situations, with no confidence left in professionals, and in deep frustration and great distrust. We knew that other families had similar experiences, but not how widespread these phenomena of collaboration breaking down were. The point here is not that more school-family collaboration is needed, but that the kind of collaboration should become more fruitful.

My personal experiences with exclusionary processes provided half of the context for this dissertation. The other half concerns opposite experiences, namely how schools succeed in establishing an inclusive culture where students' and parents' voices are invited into the conversation as legitimate contributors. As an organizational consultant, an author and a series editor on relational pedagogy from the Danish Psychological Publisher, I have come to know schools and school systems that do take seriously their relationships with parents and students. I have visited schools in San Diego, San Bernardino, Toronto (Canada), Drammen (Norway) as well as schools in Denmark, where I experienced how school professionals worked with restorative practices and responsiveness to students and parents. Through research studies, I have learned that schools in Ontario, British Colombia, 
UK, New Zealand, Australia, Mexico, Norway, Faro island, Caruba and Finland are consistently working to improve the learning and thriving of students through appreciative and inquiry-based approaches. These studies not only stimulated my interest and eagerness to keep learning myself, but also served as background knowledge in co-writing the two books; Relationsudvikling i skolen (Strengthening relationships in schools) (Haslebo \& Lund, 2014) and Kulturudvikling i skolen - hvordan? (Changing Cultures in schools - how?) (Lund \& Haslebo, 2015). Both are in Danish.

As a trained social constructionist consultant, I have worked with schools, preschools, high schools, youth schools, vocational educational training schools, school systems and other educational institutions in Denmark, that are doing a fantastic job of inviting students' and parents' perspectives into dialogue around issues of student dissatisfaction. As a consultant working with teachers and principals, I have discovered how various ways of understanding interactive troubles lead to different practices. I have seen how individualistic thinking can lead to exclusionary processes. As a counsellor for leadership teams in schools, I have discovered how problems of school-family collaboration around student learning and thriving take time and energy and play an important part of a school's reputation and its opportunity to reach national standards. Intellectual disciplines such as appreciative inquiry, restorative practices, whole school system reforms, organizational development, leadership training, management consulting, and whole school inquiry training and the like are part of my professional work. I have come to learn how school cultures can change, and how working with such intellectual disciplines can help school professionals meet the demands of struggling students and parents in new ways.

Out of this intersection between my own personal experiences with exclusionary processes as a teacher and parent on the one hand and my professional experiences with creating inclusionary school practices as a consultant, writer and serial editor on the other hand, this dissertation was born. Understandably, the discrepancies led to a curiosity that called for further investigation.

I do believe that many existing interpretations of students who are seen as causing trouble in schools do not do justice to their lives and perspectives. My personal and professional experiences, as well as my reading and study for this research, suggest that many young people are positioned in categories that do not seem to improve their chances of success at school. Rather than continuing to try to fit young people and their families into categories that do not seem to be working, I believe it is essential to reconsider responses to interactive troubles. 


\section{Organization of the dissertation}

In this section you will find an overview of the six chapters and what I will address in each of them.

Chapter 1 gives an introduction to the field of research. The research questions are presented and operationalized into propositions that can be examined.

Chapter 2 is focused on the Danish School context.

Chapter 3 is the literature review that presents theories and studies supportive of my argument.

Chapter 4 is the methodological chapter

Chapter 5 presents the data and analyzes the stories. The first research question is addressed and answered.

Chapter 6 discusses the findings and addresses the second research question. In this chapter alternative educational approaches are identified.

\section{A brief summary of findings}

The data collected for this research consists of eight short stories told by parents. The stories show how students and families are oppressed and excluded in schools, and how this influences the becoming of students (and parents) in positions labeled as deviant, deficit and the like, which marginalize them. The processes not only result in exclusion from the school, but also into the privatization of the responsibility into the family with significant consequences for the family's wellbeing. These things happen due to the particular types of interactions based on and reproducing the specific kind of thinking that offers deficit and problem-positions, namely individual-, problem- and deficit thinking (Graham, 2006). The eight short stories illustrate how communication processes performed within individualistic thinking unintentionally can lead to exclusionary processes. This happens in a fixed pattern: a vicious spiral out of which those involved can barely escape.

These stories show how students and families are positioned in at-risk-positions - by being identified as a problem, being muted, and not given many chances to escape. Due to the power distribution in the family-school relation that follows the individual-, problem-and deficit thinking, families are trapped in compromised positions. The events in each story unfold as an exclusionary process. When parents do protest against the positioning of their 
child as the problem, and against the process of muting and the exportation of responsibility into the family, they themselves are positioned as bad and problematic parents (Freeman, 2010, Knudsen, 2008; 2010). Schools depict not-yet-at-risk students and families in at-risk positions and limit the possibilities for action of all involved. Schools thus miss the opportunity to take on professional responsibility and instead marginalize families. Furthermore, schools miss the opportunity to seek, find and explore the resources the individual student and family might bring, let alone to learn from these perspectives and to improve the practices with which they are engaged.

\section{Dilemmas and discrepancies in the field}

In Denmark, both preventing dropping out and enhancing inclusion is highly regarded on the political agenda, its latest manifestation being the school reforms in 2012 and 2014, which aim to make every child as skilled as possible and ensure at least a $95 \%$ graduation rate from high schools (Rasmussen, Holm, \& Rasch-Christensen, 2015). What is interesting above all about the overwhelming direction of school policy is that public and educational debate has focused on the inclusion of students with special needs (Kirkegaard, 2014; Haslebo \& Lund, 2014; Tetler, 2007; 2011; Tetler, Hedegaard-Sørensen, Emtoft \& Ulvseth, 2012). Characteristically, while the debate is centered on the structural inclusion of students with special needs into general education, a blind eye has been turned towards the exclusionary processes affecting all students. In other words, there has been an active construction of what the problem is and what needs to be done to fix the problem, namely to make every child match the structures of schools, and thus the existing (and scarcely acknowledged in Denmark) exclusionary processes have been neglected.

For decades, when it comes to difficulties around inclusion, the explanatory model has been individualistic in its focus (Graham, 2006; Tetler, 2012). The problem is seen as the single student and his or her individual cognitive, social, emotional or personal deficits, rather than as interactive, relational or invisible exclusionary. Furthermore, there has been little that casts light on the processes that exclude young students from the class community or school community. According to Fine (1990) most research representations of youth effectively demonize young people and their non-completion of schooling, and give "a shaved and quite partial image" (Smyth \& Hattam, 2014, p. 4). Central to the viewpoint pursued by Fine, Smyth and Hattam is the argument that while the dropout problem is a real issue, categorizing and stigmatizing young people, their lifestyles and their families as the 
problem deflects attention away from the wider contributing factors and makes them invisible. The same happens when it comes to the phenomena of exclusion and marginalization of students in schools, even though this does not necessarily lead to dropping-out, but surely can do and often does. What it definitely does lead to is misbehavior, poor thriving, poor learning outcomes, isolation and sadness. All these come with the potential to break down families who are appointed or assumed to be cumbersome, demanding, impossible and unwilling to cooperate (Haslebo \& Lund, 2014; Knudsen, 2008; 2010; Madsen, 2008).

In other words, exclusion of individual students is also a matter of the social exclusion of families from the school community. Knudsen (2010) identified a number of discourses concerning "types of parents" that were found in interactions with parents, in documents and in teacher training. Interestingly, she found that the dominant understandings of "types of parents" offered deprived positions to parents and both negatively constituted and limited the possibilities for collaboration between teachers and parents. The way teachers and school professionals thought about parents and about school-family collaboration itself hindered good and constructive relationships. So despite established teacher-parentcollaboration, the social marginalization of families is very likely to happen. I will further elaborate on her studies in the literature review.

\section{Constructing the research hypothesis}

The eight stories in this dissertation are all accounts of exclusionary processes taking place in schools. My intention is to show how these kinds of interactions and exchanges in school-family relationships produce exclusionary processes and poor conditions for students to become somebody. But I wish to do more than that, since I wish to say something about the ways of thinking that are connected to these practices that ultimately lead to exclusion. I have a hypothesis of what is going on and what is at stake. Envisioning this hypothesis, I have designed the illustration below (see Figure 1.1), which depicts the process much more linearly than is the case. This is just for the benefits of simplicity. You might recognize this as the simple "input-process-output-outcome-model". 
Figure 1.1: The research hypothesis:

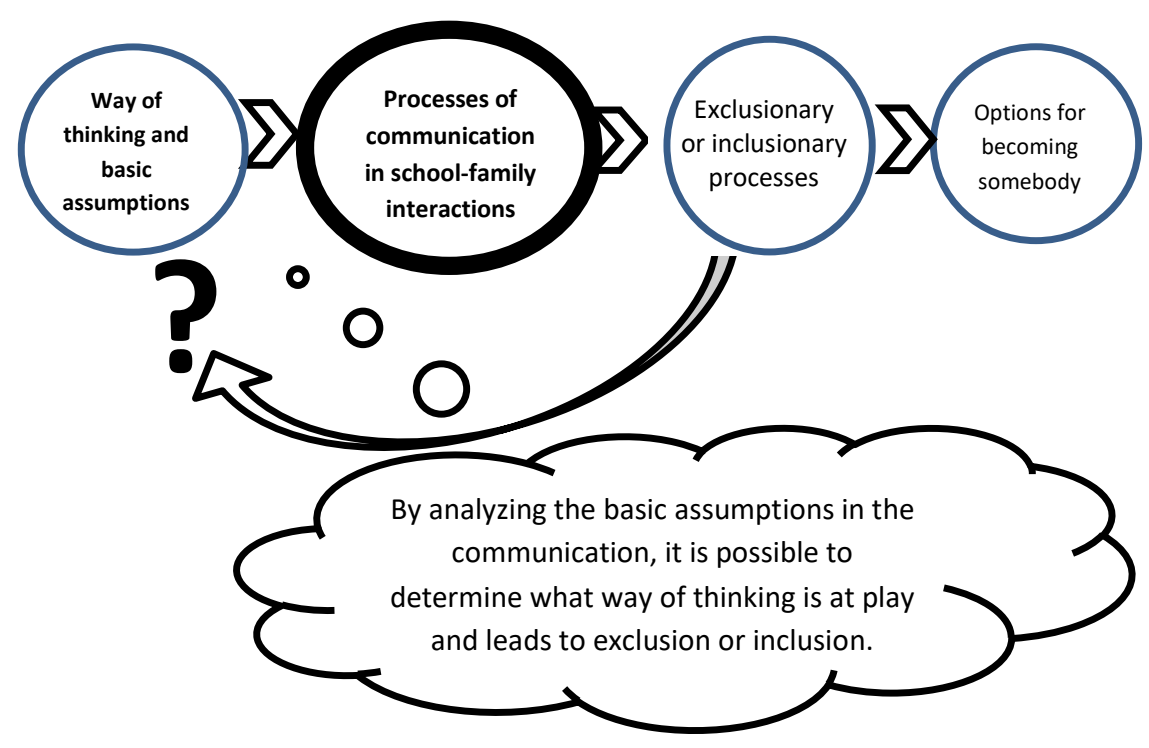

Reading the illustration is best accomplished by starting in the second circle from the left. Flanked on both sides by smaller circles, it indicates that something goes into the process of communication and something comes out of it. What goes into the process can be thought of as the input, and what comes out is can be thought of in two categories; the output and the outcome or what I prefer to just call the effects. This is the intersection between first what happens in and by the exchanges; namely specific positioning and exclusionary processes, and second; how this produces particular options for becoming somebody. Something is going on in the interactions that produce exclusionary processes, which in turn make student becoming somebody a difficult thing. The questions concern what and how. The grey swing-arrow below the central circle is pointing towards a question mark. The question is: What ways of thinking are producing the kind of interactions that are ultimately exclusionary? By looking into the interactions and determining the basic assumptions and ways of thinking within the communication, it becomes possible to understand the ways of thinking that lead to exclusion. Knowing more about this makes it possible to replace this kind of thinking with other ways more likely to produce inclusionary practices and much more fruitful and ethical relational conditions for students to become somebody. 


\section{The research questions}

The journey towards the research questions has not been direct, but more a back and forth process, although I have circled around the question of positioning all the way through. I am curious about why and how exclusionary processes evolve, why and how families find themselves positioned in unworthy positions with no options for agency, and why and how these practices seem more or less institutionalized in situations around interactive troubles. I have been guided by two research questions:

1. What ways of thinking produce the exclusionary processes?

2. How can school professionals change exclusionary processes into inclusion in a way that supports students becoming somebody?

The next step is to operationalize the research questions - to turn them into propositions that can be examined.

1. Various ways of thinking are related to various epistemologies. Ways of thinking are grounded on basic assumptions about the world: what is truth, what is a problem and what are the ways of approaching problems? By looking at the communication and how it produces exclusionary processes, I might find signposts of various basic assumptions that point towards specific ways of thinking. What do I find? What can I conclude from that?

2. When a specific way of thinking leads to exclusionary processes, it must be possible to create inclusionary processes by using another way of thinking. When specific kinds of communication create specific kinds of positions and options for action, other kinds of communication must create other kinds of positions and options. How can school professionals change what is in danger of becoming an exclusionary process so that it does not do so? How can school professionals create inclusionary processes for all students to become somebody with positive significance to relationships and the (school) community? 


\section{The importance of the research topic}

More than half a million children $(548,603)$ are enrolled in public schools in Denmark in the school year 2015-2016. 115,856 children are in private schools and 9,060 children in special schools (Danmarks Statistik, 2016). The school day begins at 8.00 am and continues till 2.00 or $3.00 \mathrm{pm}$ for the youngest students and till $4.00 \mathrm{pm}$ for the eldest students. Thus, thousands of children and young people spend thousands of hours in their school, and the school, therefore, represents a central arena in young people's lives. School is a learning environment - not only in relation to achieving academic knowledge and skills, but also in terms of developing social skills and in relation to the overall development from a child to a young adolescent. The school thus constitutes an essential framework for children's and young people's social and psychological development and plays a vital role in child and adolescent mental health. In the words of Wexler, (1992), Smyth \& Hattam (2004) and Winslade \& Williams (2012), schools are pivotal arenas for becoming somebody, and what happens in schools constitutes the conditions for students to both be somebody and become somebody. As the researchers state, it is therefore important to create a school environment that is inclusive, appreciative and safe (Rasmussen, Pedersen, \& Due, 2015).

Fortunately, according to a number of studies, surveys, and reports, it does seem to be the case for the vast majority of students in Denmark that they feel safe and satisfied in school. (I will elaborate on some of these studies in the literature review). However, the studies also show that not all children thrive in school. For those suffering in school, there are many influencing factors, such as school climate, bullying, conflicts, academic struggles, and the like (ibid.). Most schools do have policies for handling such issues, but the studies reveal that most schools are in need of more effective practices (rather than policies) for dealing with struggling students.

The annual report from 2015 of the Parliamentary Ombudsman states that Danish public schools violate students' fundamental rights when they expel or exclude them from teaching. The problem has been known for years, so in 2012 the Ombudsman recommended that the Minister of Children and Education do something about it. On this basis, the Ministry published a guide to good management in schools in 2013. But, according to the Ombudsman, he is still dealing with several cases relating to pupils who have been expelled, removed or excluded from class. In the 2015 report, the Ombudsman states that schools did have the right to act as they did, but criticized them for not following the rules of 
conduct. The overall pattern in these cases is that schools legally have difficulties in handling severe cases. For example, schools do not always comply with important rules, such as the obligation for stakeholder consultation or justification, the obligation to take notes of the decision, or to listen to students' parents. "Substantial procedural safeguards for students and their parents are thus not respected" the Ombudsman states (Danske Kommuner, April 14, 2016/no.12, p. 33). According to the Ombudsman, schools are not aware that it administratively is a managerial verdict when they decide which schools a student is to attend or in dubious cases where schools cause a student not to go to school at all. In those cases, it is required by law that the schools produce a written explanation of what it has decided and why, as well as the obligation to involve and hear the parents, and give them the opportunity to protest the decision.

Chairman of the Union of School Leaders recognizes that many school leaders are not good enough to ensure that the rights of students and families are respected. But, as he states, many municipalities as well are not good enough to ensure that their leaders are prepared for the job (Danske Kommuner, April 14, 2016/no. 12, p. 33). The Ombudsman pointed out that the current state of affairs on this topic shows that the guide from 2013 has not solved the problem. As I am writing this, The Ministry of Children and Education is investigating the Ombudsman's criticism and developing a response.

I find it most disturbing that Danish public schools violate students' and parents' fundamental rights, when they expel or exclude students from teaching or from the school in general, and it is urgent to do justice for these families. The practices of expelling and excluding students, my research suggests, happen quite a lot and in various ways. My aim is not so much to document the frequency as to show how such exclusionary processes evolve. They are pivotal, not only to understanding exclusionary processes in schools, but also to changing these practices into more inclusionary ones.

This study differs from other related research by its focus on the invisible exclusionary processes taking place in school-family relationships. As a research topic, invisible exclusionary processes of students and families hold great importance and relevance for the future. However, in research and public debate, the topic has not been given much attention. Invisible exclusionary processes of students and families have an impact not only on people's lives, but also on the school community and society in a broader context. It directly impacts students and families mentally, physically and socially. They become stigmatized and marginalized and indirectly all members of the school community are influenced by the exclusionary culture, language and patterns of relating. Related to this 
wider context are issues of societal inequity, at-risk youth and at-risk families, as well as issues concerning the quality of education, the moral purpose of education and lack of trust in professionals and public education. I will address seven condensed arguments for the importance of the research field, giving reasons why knowing more about this topic is beneficial to, not only students and their families, schools, teachers and principals, but also society as a whole.

\section{The human suffering and lost hopes for the future}

On a school level, processes of exclusion, regardless of whether they are intended or not, play a pivotal role in everyday life (Fine, 1990; Haslebo \& Lund, 2014; Smyth \& Hattam, 2004; Winslade \& Williams, 2012). As alluded to above in the dedication and acknowledgements, exclusionary processes stress families and destroy hopes for a bright future. Practical inclusionary challenges are connected to interactive troubles such as bullying, conflicts between students and between students and teachers, conflicts in schoolfamily relationships and student truancy. The fact that conflicts and bullying in schools are pivotal for poor wellbeing in schools is well acknowledged (Ottosen et al., 2010). Many resources (mental, time and economic) are spent trying to curb such problems, but combating exclusion and poor well-being remain a substantial part of school life.

\section{The moral purpose of education}

Questions about the moral purpose of education are contestable and widely debated internationally as well as nationally (Barber, Mourshed \& Chijioke, 2010; Biesta, 2011; Fullan, 2003; Gergen, 2001; Zipin, Fataar \& Brennan, 2015). On the one hand, it seems obvious that children need to learn how to read, write and do math and later on master a range of academic skills in many subjects. On the other hand, schools are where future generations grow up to become productive citizens as well as becoming somebody on a personal level (Fullan, 2003; Smyth \& Hattam, 2004; Willis, 1977; Zipin, Fataar \& Brennan, 2015). In the Danish context, both academic achievement (uddannelse) and processes of becoming (dannelse) are highly regarded and closely connected to the moral purpose of education. As Susan Tetler (2011) argues, schools must produce positive self-images in order for students to learn, thrive and become independent, skilled, constructive and responsible citizens. If children are struggling with being stigmatized, marginalized or excluded, schools are failing their responsibility to produce such positive self-images. From 
this viewpoint, stigmatization, marginalization and exclusion are great threats to schools' ability to fulfill their moral as well as formal purposes.

\section{The difficulties of transforming schools}

In most countries, transforming education and making ways for innovative, creative and equal learning for all students are made through a range of school reforms (Cuban \& Tyack, 2003; Hargreaves \& Fullan, 2012; Lund \& Haslebo, 2015; Rasmussen, 2015; Sahlberg, 2015). It is common knowledge that changing schools is difficult and requires cultural transformation (Hargreaves \& Fullan, 2012; Hattie, 2013; Lund \& Haslebo, 2015). One challenge is to be responsive to students' and parents' perspectives and to integrate them in school development (Hargreaves \& Fullan, 2012; Knudsen, 2010; Lund \& Haslebo, 2015; Smyth \& Hattam, 2004). Achieving new knowledge about invisible exclusion of students and parents is pivotal to changing schools to provide spaces for all children to become worthy and well-functioning citizens.

\section{Societal implications and increased inequity}

The national Chairperson of the Union for Municipal directors of Social-, Health- and Employment in Denmark stated in 2016 that most of the marginalized young people outside education and not in employment have early in life had negative school experiences (Skjødt, 2016). The chairperson mentions bullying and "other things in school" and concludes that most marginalized youth have had negative school experiences that affect their long term aspirations. She argues that schools play a significant role in the long term perspectives for quality of life. According to a study by Schultz-Nielsen and Skaksen (2016) 20\% of young people at the age 22-23 are not in education or employment seven years after they graduated ninth grade. Among young people in the $25-29$ age group, $7-8 \%$ are not in education or employment for about two consecutive years. As a democratic welfare society like the Danish one, it is problematic that a substantial portion of young people live on the margins of society and on public support services, instead of contributing to the maintenance of the welfare society for future generations.

\section{Economic implications}

According to Schultz-Nielsen and Skaksen (2016), early negative school experiences are directly connected to marginalized youth not being in education or in a job, which the study estimated to cost fifteen billion kroner a year. Compared to the cost of failed 
integration of non-Western immigrants which is 16.5 billion kroner a year, and which is widely debated, the situation of social marginalization has been given very little attention and is a serious economic, social and psychological problem. For economic reasons alone, the invisible social exclusion of students and families is highly relevant to explore in order to avoid the pipeline to a life on public support and on the margins of society.

\section{One-eyed research}

Most research on related topics like dropping out, inclusion and exclusion focuses either on socio-economic factors or on the effects of structural inclusion, which has to do with the proportion of children with special needs who are included in general education. Only a few of these studies include student voices and even fewer include voices of parents. Research acknowledges that ideas of inclusion change and impact roles and relationships in schools - mainly the role of the teacher and, therefore, teacher competencies and education. But what seems overlooked is firstly how ideas of inclusion change the premises of schooling and point towards the nurturing and strengthening of relationships - and to restoration when these are damaged. Secondly, ideas of inclusion not only concern students with special needs, but all students, which in turn means re-thinking what it means to be normal or special and rethinking what inclusion means in order to develop new understandings of inclusionary and exclusionary practices, not only as results of political decisions, but as processes of relating, communicating and engaging. According to a metastudy of educational research by Marinosson, Ohna and Tetler (2007) there is an evident need for studies that both involve student voices and emphasize student participation in relation to different pedagogical contexts, where it is not the students, but the school practices that are problematized. In particular, there is a need for research that analyzes exclusionary and inclusionary processes as they evolve in pedagogical and social settings. Furthermore, they continue, it is necessary to analyze factors that enhance active participation for students and conduct research that says something about how to give voice to students in pedagogical settings, where exclusionary and inclusionary processes take place.

\section{Ongoing and unresolved inclusion efforts}

What seems to have been the overall concern for the last three to four decades in Denmark is the effort to enhance structural inclusion (Alenkær, 2012, Petersen, 2015, Tetler, 2015). In its latest manifestation, the inclusion reform in 2012 caused heated debate in 
schools, in research and in the public. It is a continuous question why the aspirations for an inclusive school have not succeeded despite decades of great effort and investment. My contestation is that research and political intentions have paid too little attention to changing school cultures. In practice that means changing the basic assumptions and ways of thinking, which is not easy, nor done quickly. It does require the willingness to produce the necessary knowledge, which includes knowledge about invisible exclusionary processes going on in everyday interactions, and which mainstream explanatory models in many educational settings are continuously overlooking (Marinosson, Ohna \& Tetler, 2007; Roman, 1996). For many reasons, among the most significant mentioned above, more knowledge around phenomena of exclusionary processes in schools will enrich and qualify the striving towards inclusionary school cultures that enable students to become somebody for the benefits of themselves, the schools and society.

\section{A brief outline of the methods of inquiry}

\section{How I collected the data}

The data consist of eight short stories that I collected by using a snowball sampling method. Snowball sampling is useful and practical in studies that seek to understand and sample concealed populations such as the deviant and the socially isolated (Atkinson \& Flint, 2001). In chapter 4 , I will explain in more detail how this process evolved and how we cocreated the stories.

\section{How I analyzed the data}

To understand the exclusionary forces in the communication between schools and families, I created a spiral analysis that integrates positioning theory, narrative inquiry and coordinated management of meaning (CMM). The spiral analysis describes interactions or conversations, in which people involved tell us what "it makes" (Foster \& Bochner, 2008). Narrative constructionist inquiry is based on a moral concern with imagining new, different and better ways of living (Gergen, 2015). A person is seen as a storytelling animal (Mclntyre, 1981) who naturally constructs stories out of life (McAdams, 2006). Stories form the basis for and pave the way for who we are and what we might or might not do, as well for who we might become. 
$\mathrm{CMM}$ is a constructionist communication theory designed to analyze "what communication creates". It understands the world as spirals of interactions in which relationships, positions, options for actions, and identities are created. CMM describes interactions in which people tell us what social worlds are created (Pearce, 2006, p. 11). CMM is concerned with the process of 'becoming somebody' in interactions as well as in finding alternative ways of enacting conversations and interactions that lead to potentially better social worlds.

Positioning theory is an approach to understanding "how people use words (and discourse of all types) to locate themselves and others" (Moghaddam \& Harré, 2010, p. 3). Furthermore, "it is with words that we ascribe rights and claim them for ourselves and place duties on others" (ibid. p. 3). By using positioning theory it is possible to go into detail about how communication positions students and parents and creates and connects with certain ways of thinking.

Combining these theories into a spiral analysis makes it possible to look at the communication in school-family interactions and to say what happens that makes the interactions ultimately exclusionary, and how school professionals can act differently in order to create inclusionary processes instead.

\section{A preview of chapter 2}

In chapter 2 I will present the Danish School context for both international and national readers. Giving a brief historical overview of the policies of public education serves the background of going more into specific data on student wellbeing, academic outcome, school problems, inclusion and the like. Large compounds of data are introduced as well as research results, studies, evaluations and reports. These statistics are put into a societal frame, where related issues of marginalization, inequality, social reproduction theory, and school-family collaboration issues are given special attention. 
Chapter 2

Literature Review

Part One

\section{The Danish School context}




\section{Contextualizing}

This chapter introduces the Danish school context to provide the reader with a framework for the study and the argument that I am presenting. I wish to give an overview of the current state of affairs regarding student academic outcome, general wellbeing, school wellbeing, inclusion and various problems in schools by presenting some selective debates in these matters.

After having built the contextual foundation, I will touch upon another important debate, which regards changes in the dominant understandings of reproduction theory and social marginalization. New Danish research results have shown that a substantial part of marginalized youth is brought up in families with no indicators of social marginalization. Thus the traditional understanding that social marginalization is reproduced from one generation to the next does not apply for these students (Benjaminsen et al., 2015). Supporting what my own study suggests, this research points toward some things that produce the marginalization that happen outside of families, such as in daycare and schools. Benjaminsen et al. argue that research needs to take a closer look at such processes, but do not say anything about what they might be or where to look. My contribution offers one significant and possible suggestion.

A third debate regards school-family collaboration, where I shall present the results of a discourse analysis that argues that school-family relations are pre-disposed to fail (Knudsen, 2012). The research shows that of the five dominant discourses around schoolfamily collaboration, there is not one that invites the parents into the relationship as equal and influential partners. Furthermore, neither of the available discourses invites school professionals into listening responsively to parents' accounts. The discourse analytic findings support the part of my argument that concerns the positioning of parents as in deficit, deviant, problematic and bad parents, in relation to school-family interactions. Let us have a look at the current state of affair in Danish schools.

\section{The Danish school context}

In the spring 2013, under the left-wing government, a new school reform that emphasized a teacher-led whole-school-day, was agreed upon to be implemented in 2014. The intentions were to integrate traditional academic teaching activities with play and leisure activities. The aim for the school reform was to stimulate an academic boost and 
secure the wellbeing of all students, and it was greatly inspired by the Ontario School reforms. The intentions are expressed in three goals for public schools:

1. All students in the public school are to be challenged in order to be as skilled and competent as possible.

2. The public school has to reduce the impact of social background in relation to academic outcomes.

3. The trust and wellbeing in the public school has to be strengthened through respect for professional knowledge and practices.

(Rasmussen, Holm \& Rasch-Christensen, 2015, p. 14)

From the legislative texts (Undervisningsministeriet, 2013, p. 23) it is stated that at least eighty per cent of all students have to be good in reading and math and that this has to show in the national assessments. The proportion of the best performing students in the subjects of Danish and mathematics has to increase year by year. The proportion of the lowest performing students in the national assessments in reading and mathematics has to decrease year by year. The general wellbeing of all students has to increase.

Furthermore, the goals are to be achieved through a longer and more varied school day where flexibility, openness to society and motivation are pivotal focal points, and where the learning and wellbeing of students are the main foci of all activities of the school.

Due to the unfortunate coincidence of a severe conflict, a subsequent lockout and the implementation of the reform, many teachers and school professionals met the reform with criticism and mistrust. Even though much in the reform was already established in many municipalities, the Minister of Education struggled to engage schools in reforming and restoring the communication amongst the parties. These efforts entailed new concepts such as New Nordic School, The Wholeday School idea and Activity Lessons, to mention a few. Together with the reform, a new law for teachers' working time and conditions was implemented (Danmarks Lærerforening, 2013). It restrained teachers' time and reduced the time for preparation of lessons. It was understood as a harsh showdown with teachers' autonomy, freedom and professionalism. The year before, in 2012, another reform was implemented, the so-called "inclusion reform", aiming to break the exclusion of children to special education (Rasmussen et al. 2015). This meant that many children were moved back to ordinary schools and classes, but without ensuring the teachers or the included children would receive additional support or resources. These two elements are very important in order to understand the critique from teachers. The new school reform is now in its third 
year and still meets a lot of challenges and critique from teachers, educational scholars and some parents, while others express their support, enthusiasm and hope that the reform will get a chance to prove its worth and potentials.

The short stories in this study all stem from the period 2012-2015 and thus represent two school years before - and one year after- the introduction of the great reform in 2014. It is likely that the introduction of the reform might have influenced student satisfaction, at least in the initial years. Nevertheless, the reform is not an issue addressed in the stories.

\section{Student academic outcome}

One thing is the political aspirations for the educational system. Another thing is how the status quo stacks up in terms of academic achievements and the wellbeing of students. Therefore, I shall briefly touch upon some international comparative study results. As part of the OECD-collaboration Denmark contributes to various international comparative educational studies such as the PISA (Programme for International Student Assessment), the PIRLS (Progress in International Reading Literacy Study) , the TIMMS (Trends in International Mathematics and Science Study) and others.

In the PISA assessment, which is established collaboratively among OECD-countries and a series of partnership countries, the purpose is to measure how well fifteen-year-olds are prepared to meet the future challenges of the information society. This is done by measuring and internationally comparing the academic competencies of the fifteen-yearolds in three academic domains; mathematics, reading and science. The PISA assessment has been done every third year since 2000 and Denmark participated all five times. In 2012, 7,481 students from 339 schools in Denmark participated. Out of the 34 OECD-countries, Denmark is number 15 in mathematics, number 18 in reading and number 19 in science. Compared to the other Nordic countries, Denmark is below Finland and above Norway, Sweden and Iceland.

The PIRLS assessment compares internationally the reading skills of students in fourth grade. The results of the two latest PIRLS studies in 2006 and in 2011 showed that Danish children in fourth grade are amongst the best readers in the world. Only students in four other countries do better than the Danish children.

The TIMSS has been conducted since the 1960s. Since 1995, Danish students have improved their competencies in mathematics and science by a whole class level (Aarhus Universitet, 2011, p. 5). The positive development continues from 2007 to 2011 . Eight 
other countries are doing better than Denmark, but Danish students do better than students from Norway and Sweden in mathematics, but not as well as Finnish students. In science, Danish students do better than Norwegian, just as well as Swedish, and not as good as the Finnish (p. 3).

\section{Student wellbeing in general}

On issues of student wellbeing, Danish research institutions offer a massive number of studies and research projects. The Det Nationale forskningscenter for velfærd ${ }^{1}$ (SFI) published a book in 2010 based on a comprehensive survey study concerning the welfare and wellbeing of Children and Youngsters in Denmark (Ottosen et al., 2010). The survey left the overarching impression that life starts well for the vast majority of children. Most children are in good health during the first years, they are well-adjusted in day care institutions, and they have healthy eating and exercise habits. When beginning in school, they are happy about going to school, and their parents think they are doing well academically. They have an active leisure time and the vast majority of eleven year olds are happy about life. The overall impression from the survey is that families are taking good care of their children from early on. They grow up in good material conditions and receive adequate care from their parents.

The good trend that has caught on in the early years does not continue, however, but is gradually trumped by an increasingly risky and problematic life (pp. 8-9). The joy of going to school decreases to some extent, as well as students' confidence in their own academic abilities. As the researchers conclude, "The school is a selecting and segregating process" (p. 9) (my translation). The picture becomes more serious when looking at 19-year olds, where about $33 \%$ are not in education. Two thirds of these are in jobs, while the rest do not do anything. This means that there is still a considerable distance to achieving the government target of $95 \%$ of young people in education. In the next section, I shall dig into student wellbeing in schools.

\section{Student wellbeing in schools}

\footnotetext{
${ }^{1}$ In English: The Danish National Centre for Social Research. http://www.sfi.dk/
} 
Another comprehensive research study - the so called baseline measurement - done by Det Nationale Forskningscenter for Velfærd (SFI) in the spring of 2014 involved 28,478 students from 213 schools (Hansen, Friis-Hansen \& Jensen, 2015). Out of the share of students, $29 \%$ were in fourth grade, $27 \%$ in sixth and $43 \%$ in eighth or ninth grade. The purpose of the baseline measurement was to establish a benchmark starting point for future measurements to compare changes and differences before and after the introduction of the great school reform in 2014. The increased interest in students' wellbeing builds on the knowledge that students' academic learning outcomes are closely connected to their wellbeing (Gutman \& Vorhaus, 2012; Hattie, 2008). The researchers state, that high student wellbeing can legitimately be seen as a societal ethical obligation, since welfare problems in childhood increases the risk of welfare problems as an adult (Hansen, Friis-Hansen \& Jensen, 2015). An index of students' general school wellbeing was made on the basis of three questions concerning how students:
1. enjoy going to school
2. are happy about their class
3. feel they belong to the school community.

In the report, the researchers conclude that students generally thrive in Danish public schools. About $75 \%$ of students confirm that they feel good in school, while $4 \%$ confirm that they do not feel good in school at all. This leaves $21 \%$ of students in between feeling good and not feeling good at all. Altogether $25 \%$ of students did respond as not having a high score for feeling good about school. This corresponds with one student out of every four. In a class with 24 students, this means that six students in every class are either not feeling good or not at all good in school.

When it comes to academic engagement and interest, about $63 \%$ of students estimate that they have a high academic interest, while $5 \%$ estimate that they have a low academic interest. Students in fourth grade stand out as having both a high good feeling and a high academic interest. The academic interest decreases the older the students become. This leaves as much as almost one third (32\%) in the category of neither having a high, nor a low academic interest. The researchers do not take up this question about these students' academic interest. Is it poor? Or average? Or fluctuating between high and low? Adding the $32 \%$ with the $5 \%$ having a low academic interest, it leaves $37 \%$ in the category of not having a high interest academically.

When looking at students' relationships to their teachers, the study found that a majority of students liked their teacher, while some students - especially the older ones - 
are critical of the teaching. A majority of students are positive about specific characteristics of the teaching and teachers' expectations. Again, the study shows that the older the students, the more critical. The study also looked at family support as part of the students' general wellbeing in school. Responding to questions about whether students and parents had dinner together and whether parents asked about the school day, the report shows that the majority of students have high support from their families. As many as $95 \%$ of the students are right at the top regarding the feeling of family support, while $1 \%$ is in the lower third of the index, leaving $4 \%$ in the middle. The study was repeated the following year and the newly released results (Nielsen, Hansen, Jensen \& Arendt, 2016) show a similar picture with only slight differences.

In the Skolebørnsunders $\varnothing$ gelsen $2014^{2}$ study done by Statens Institut for Folkesundhed, pupils were asked about a number of elements, all of which are essential for creating a healthy school environment. These include various facets of general school satisfaction and bullying. The study is an indicator based study, combining both register data from Danmarks Statistik as well as a survey study including 6,267 pupils (Rasmussen, Pedersen \& Due, 2015). On the question “How do you like school these days?" students were given four possible answers to choose among: "I really like it", "I think it is fairly okay", "I do not really like it", "I do not like it". The report only shows the proportion who responded that they really liked school. Among the eleven-year-olds $38 \%$ of girls and $43 \%$ of boys reported that they really liked the school, while the corresponding proportion among fifteen year-olds, is $23 \%$ of girls and $21 \%$ for boys. The report does not explain how the rest of the population responded in the three other categories. But from the numbers it can be assumed that for the fifteen-year-olds $77 \%$ of the girls and $79 \%$ of the boys - as well as 62 $\%$ of the eleven year-old girls and $57 \%$ of the eleven year-old boys - either responded "I think it is fairly okay", "I do not really like it", or "I do not like it".

In 2014 the Det Nationale forskningscenter for velfærd (SFI) did the same survey as in 2010 based on a comprehensive survey study concerning the welfare and wellbeing of Children and Youngsters in Denmark (Ottosen et al., 2014). When looking at the indicator for children's and young people's satisfaction with the school among 7-19 year olds, 58\% replied that they really liked school, $37 \%$ found it fairly okay, $4 \%$ did not really like it, and $1 \%$ did not like it at all. In the analysis on social exclusion the researchers focus on the $5 \%$ not enjoying school. The study shows that school satisfaction varies by age and partly by

\footnotetext{
${ }^{2}$ In English: Schoolchildren Survey in 2014from the The State Institute for Public Health
} 
gender. At age seven the vast majority of mothers reply that their children are very happy about school, the girls more often $(81 \%)$ than the boys $(71 \%)$. The student satisfaction decreases however during schooling. At age eleven, where most students are in fifth grade, almost $50 \%$ are very happy about school. By seventh grade only about $40 \%$ are happy about school and the proportion of students not happy about school at all has increased to $7 \%$. Among the 19-year olds that are in education, the picture changes again. For this category $57 \%$ of the students are very happy about school, however the 19-year olds are in education on a voluntary basis and those most unhappy about school have been sorted out.

As part of the school reform in 2014, all public schools (primary and special schools) are obliged to conduct annual wellbeing surveys among students from $0^{\text {th }}$ to 9 th grade. The first National Wellbeing Measurement was conducted in the spring of 2015. The second was carried out just at the beginning of 2016 and the results are being processed by the Styrelsen for It of Læring at the Ministry of Children, Education and Gender Equality, as I am writing this. Students in fourth to ninth grade were asked forty questions, and students in first to third grade were asked twenty more simple questions. In collaboration with a number of experts the Ministry of Children, Education and Gender Equality, developed five differentiated indicators of wellbeing of students in fourth to ninth grade. These were:

1. Social wellbeing: deals with students' perception of their belonging to the school, class and community, as well as safety and bullying.

2. Academic wellbeing - dealing with students' experience of their own academic skills, concentration and problem-solving ability.

3. Support and inspiration - deals with students' experience of motivation and participation, as well as service, teacher help and support.

4. Peace and order - dealing with students' experience of tranquility and noise in class and class management.

5. General school wellbeing - is a comprehensive indicator consisting of the 29 questions included in the four differentiated indicators.

(Styrelsen for It og Læring, 2015)

I will now try to elaborate the results of the first wellbeing survey. However, it comes with some reservations. The report is fairly summaric, the tables in the report are rather ambiguous and the text focuses mostly on the responses related to high well-being. Nevertheless, the results of the first wellbeing survey, where as many as 270,000 students in 
fourth to ninth grade responded, reveals that $29 \%$ of the students rated their general school well-being as very good, $63 \%$ of the students rated their general school well-being as good, and $7 \%$ of the students rated their general school well-being as poor or very poor. When looking at the social wellbeing, $59 \%$ of the students rate this as very good, $34 \%$ as good, and $6 \%$ as poor. When looking at the academic well-being $10 \%$ of the students rated this as poor, while $59 \%$ rated it as good, and $30 \%$ as very good. $35 \%$ of the students' rated support and inspiration as poor, while $55 \%$ rates it as good, and $10 \%$ as very good. The last indicator is peace and order, which $16 \%$ of the students rated as poor, $59 \%$ as good, and $25 \%$ as very good. To sum up the picture all together on the ratings 'poor and very poor', $7 \%$ are in this category when it comes to general school well-being, $6 \%$ when it comes to social well-being, $10 \%$ when it comes to academic well-being, $35 \%$ when it comes to support and inspiration, and 16\% when it comes to peace and order (see Figure 2.1).

Figure 2.1. Distribution of students' average in each indicator of wellbeing, 4th-9th Class.

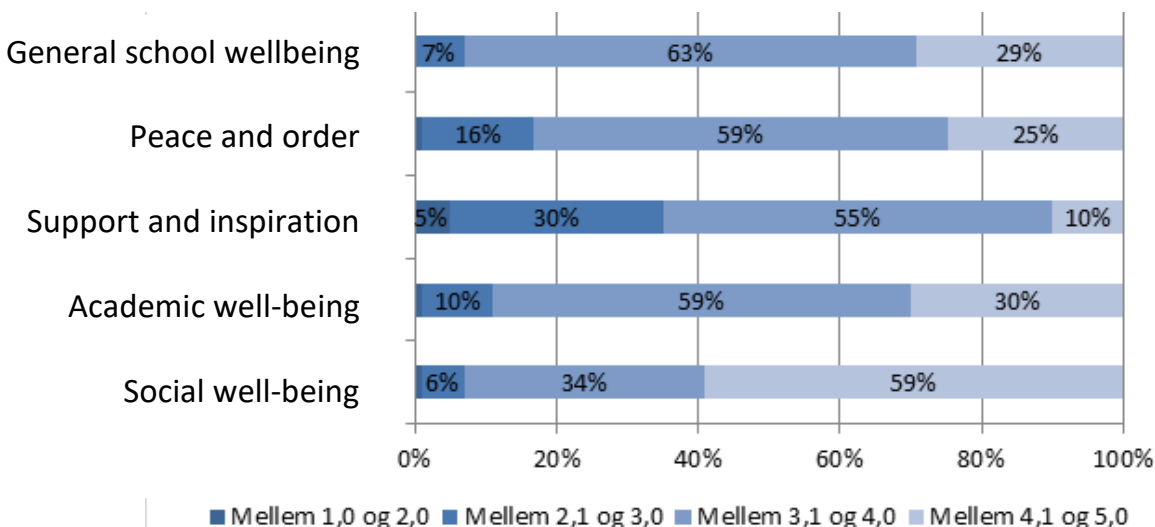

(Styrelsen for It og Læring, 2015)

\section{School problems}

Ottosen et al. (2010) state that negative experiences with schooling can contribute to marginalization (p. 84). The researchers collected a number of questions about difficulties in school to a comprehensive indicator of whether children and young people at the age of eleven, fifteen, and nineteen years are having school problems. The students were asked about how they felt in school, how often they felt sad or kept them to themselves, and whether they found it difficult to concentrate in class, if they were having conflicts with 
other students or with teachers. Nearly half (49\%) of all the children and young people were at the time of the study experiencing school problems, and about half of those who experienced difficulties had problems in several areas. The results show first, that the extent of perceived problems increases with age until fifteen years and then plummets drastically, probably due to the nineteen-year-old students being enrolled in education on a voluntary basis. The most unhappy students drift out of education and thus do not appear in the sample. Secondly, it appears that the extent of experienced school problems vary with family types. Children of single parents (57\%) and children in family care (58\%) are more frequently experiencing school problems than children in "first marriage families" (47\%). The differences are especially pronounced in the youngest age groups, but the analysis provides no basis for any real explanation of the variations. However, the result that students with all kinds of family backgounds have negative school experiences, may form the basis for a hypothesis that children from broken homes have fewer resources to draw on, when experiencing school problems.

A study done by DCUM and the Children's Counsel from 2009 shows that at least every tenth student had experienced bullying from a teacher within the last half year (DCUM og Børnerådet, 2009). Another study done by the Children's Counsel from 2004 showed that one quarter of victims of bullying did not talk with anyone about it, while one third experienced that they cannot get help from an adult in a bullying situation, and one quarter experienced that no adults took action to stop the bullying. These studies indicate that school problems are not only caused by student-to-student conflicts, or due to individual "deficits", but can be caused by teachers either as the bully (or at least students feeling bullied by teachers) or by ignoring or accepting the bullying.

\section{Shifting schools}

Danmarks Statistik (The Danish Statistics Institute) possesses register databases on school changes, but no records of the numbers of school changes in Denmark are officially available. For a large amount of money they can offer to do a register analysis, but no one has yet asked for that. As a PhD student enrolled in a Dutch University I am not entitled to access these data.

There is very little research on students shifting schools done in Denmark. Juelskjær (2009) has done a PhD on school shifts and identity formation in the new school, and she argues that her search for data and studies on shifting schools gained no success. Also 
Ottosen et al. (2010) claim that not much research has been done on this topic. Taking up this issue, Ottosen et al. (2010) looked at school shifts with regard to family types, divorce, mobility (change of residence), social disparity and school problems such as poor wellbeing, bullying and conflict. They state that almost no seven year olds have experiences with shifting schools, but about $50 \%$ of the 15-19 year olds have had one or more school shifts during their schooling (p. 85). When looking at to what extent shifting school was due to school problems, the researchers found that more than every third (36\%) child and young person in the ages of seven to nineteen years claimed that they had experienced moving to a new school due to school problems.

According to the article, "Mistrivsel får børn til at skifte skole" ${ }^{3}$ by Bruun-Schmidt (2014) in the highly regarded newspaper Politiken, many municipalities and school principals were well aware of the numbers of children that changed schools due to poor wellbeing. In the article, a school principal estimated that poor wellbeing of the student is the cause in eight out of ten cases, where parents moved their child to another school. It is difficult to compare the numbers between municipalities, since they counted them differently. Most often these numbers were not made public. However, some numbers regarding the four largest municipalities in Denmark, were presented in the article. Regarding the population of students in $0^{\text {th }}-9^{\text {th }}$ grade in public schools in the year 2012/2013,4.4\% in Copenhagen, 4.6\% in Aarhus, $4.9 \%$ in Aalborg and $7.0 \%$ of the students in Odense changed schools. Except for Odense, these numbers did not include shifting schools from ninth grade to tenth grade or to high schools, neither did they include shifting to special schools, Efterskoler (boarding schools), private schools or shifts due to family change of residence. If we take the municipalities' own accounts at face value, this means that around $4-5 \%$ that year shifted schools due to poor wellbeing in schools. We do not know if it is the same number each year, if it changes from year to year, or if there are trends and patterns on a national, municipal, geographical or local school level. From the article it is not possible to know at what grade the school shifts take place, nor what kinds of school problems are causing the poor well-being. In answer to a question of why they moved their child to another school, a parent stated that their child had been suffering from bullying and social exclusion. After having tried to establish a collaboration with the school on solving the situation for more than one and a half years - and only getting the same reply that the school was aware of the situation - the parents felt so frustrated and impotent that they saw no other option than to

\footnotetext{
${ }^{3}$ In English: Poor wellbeing get children to change schools
} 
move their child. A Counsellor at the Parents Advisory in Landsorganisationen Skole og Forældre ${ }^{4}$ said that more and more parents sought advice in cases of poor student wellbeing and considerations on changing schools, and in almost no cases the situation concerned academic problems or dissatisfaction with the academic level in the school.

To sum up the surveys and measurements presented in the previous sections they all together draw a picture that many students in public schools in Denmark are happy about going to school. However, a considerable proportion is not. Many of those not feeling happy in school have experienced changing schools because of poor wellbeing in school. Here issues of conflict, bullying and interactive troubles are alluded to. However the surveys and measurements do not say anything about the issues related to poor wellbeing in schools, nor much about the extent and duration. There are not any direct links to school culture, even though it is mentioned that school culture and student wellbeing are interconnected. There are no links to inclusion and exclusion either, although exclusionary processes are mentioned as related to poor school wellbeing. The surveys and measurements are ultimately quantitative and aimed the numbers and categories (gender, social status, age) of students feeling happy, less happy and not happy in school, but not searching more qualitatively the issues and causes around poor student wellbeing and shifting schools.

\section{The inclusion problem}

Fisker and Szulevics (2015) offer an overview of the state of inclusion in Denmark for the last forty years. They point out that for four decades it has been commonly accepted that far too many children have been segregated into special schools and that they would benefit from going to general schools. Internationally there is a strong focus on inclusive education as well, as seen in the large number of international declarations and intentions by which individual nations and states are committed. Both inclusion and exclusion have been contested in immense amounts of social and educational research, public debate and political argument over the last few decades, not only in Denmark but also internationally. Rasmussen, Holm \& Rasch-Christensen (2015) state that the development of more inclusive schools has been on the political agenda in Denmark for decades, but despite substantial amounts of resources spent, the ideal of inclusion has proven difficult to realize. Thus still

\footnotetext{
${ }^{4}$ In English: The National Union of School and Parents.
} 
today, the issue of inclusion in schools is socially, economically and politically highly relevant. Rasmussen et al. (2015) argue that in 2012 up to $6 \%$ of all students were placed in segregated settings, such as special classes and special schools, while as much as $30 \%$ of the total budget for public primary schools was spent on these services.

Furthermore, Esmark (2006) claimed that the idea of integration was supported by the critics of the socio-educational research that grew throughout the 1970s. The critique that schools basically contributed to creating difficulties for students in schools followed. Rasmussen et al. (2015) argued that the critique pointed out how the education system was strongly reproductive and failed to both create social mobility and social equality. The focus was on integrating students with special needs into general schooling, but without any requirements that the school needed to change or adapt. By contrast, it was the integrated students that bore the responsibility for adapting to the demands, norms and values of the school, and so it maintained an individualistic focus. Throughout the 1980s and 1990s, the idea of integration was criticized for actually leading to exclusion, due to the focus on the difficulties and deficiencies of the individual student, and then the idea of inclusion was substituted. Ratner (2013) explained that the critique was that the individualistic focus implied both some pedagogical limitations, as well as exposing the individual student with special needs as different from other students in the group.

Hence, Rasmussen et al. (2015) argued, the idea of inclusion was based on a relational starting point, where 'special needs' were not seen as an individual characteristic related to the individual child, but instead as mediated historically, culturally and discursively and closely connected to the school as a specific site of cultural and pedagogical praxis.

Fisker and Szulevics (2015) state that during the 1990s, more students in socioemotional difficulties were included in general education, which was depicted as the cause of more noise and turmoil in the classroom and therefore criticized. Studies showed that just a few noisy students sabotaged the teaching (Undervisningsministeriet, 1997) and the response to that was that more students were enrolled in special education. At the same time, Ratner (2013) pointed out, many more students were diagnosed with attention deficit hyperactivity disorder, nonverbal learning disorder, minimal brain dysfunction, autism, tourettes syndrome and the like. Hence, Tetler (2011) argued many students were segregated into special education, and Denmark found itself in a paradoxical situation, where more and more students were enrolled special education, despite the ideal of integration and inclusion. 
Rasmussen et al. (2015) stated that the inclusion problem continued in the beginning of the 2000s, where even more students were segregated from general education to special schools in spite of the aim to do the opposite. During the 2000s, researchers proclaimed that for many reasons this practice was problematic academically, socially and personally for the segregated students. Socially, it was problematic, because it contributed to a far too narrow understanding of normality and a reduced level of tolerance.

A decade later Tetler (2011) pointed out that, despite decades of intensive efforts into integration and inclusion, segregation and exclusion of students with special needs were still every day practices. At the same time, she stated, an increased resignation towards the idea of inclusion was growing, and she asked what the barriers were for integrative processes in the Danish School system. From her viewpoint of a special education perspective, she pointed at two factors: 1) the attitudes of teachers, and 2) unintended effects of support initiatives. She concluded that this was thought-provoking and called upon new knowledge, insights, attitudes and practices.

In 2011, the government announced Inklusionsloven ${ }^{5}$ (L379 of 28.04.2012), which was adopted in April 2012. The goal was that $96 \%$ of all students by the year 2015 were to be enrolled in general education. It was the responsibility of the individual school to provide additional support to students with special needs of up to nine hours a week, and schools were given significant economic incentives to include more students. According to Baviskar et al. (2014), the number of students enrolled in general schools increased from 93.1\% in 2010 to $95.5 \%$ in 2014. The numbers from 2015 have not yet been officially published.

According to Dyssegaard, Larsen and Tiftikci (2013), no negative effects on the academic and social development of general students were to be found by including students with special needs into general education. However, it was found pivotal to students with special academic and social needs that schools had an overall vision for and positive attitude towards inclusion of students with special needs in general education. The report stated that teachers with a negative attitude towards including students with special needs had a negative effect on the academic development of these students. Furthermore, "It can lead to what is called social contagion, which is the stigmatization of students with special needs by their classmates" (p. 83). The report clarifies "that teachers, teaching assistants and special teachers risk participating in the stigmatization, if they do not have the required special training" (p. 83). (My translation)

\footnotetext{
${ }^{5}$ In English: The Law for increased inclusion
} 
The report concluded that including students with special needs is not only possible, but also had the potential to have a positive impact on all students. However, it required teacher training in interventions for students with special needs, access to resource persons, counselling and direct support in the classroom as well as knowledge about evidence-based teaching methods and interventions for special education.

Nevertheless, Jørgensen, Blankenberg, Skall and Schjerbeck (2016) pointed towards a series of problems with the current state of the art in schools. Even though more students were enrolled in general education the data suggested that not all students learn and thrive accordingly and, in some cases, both the included children and the other children suffered from the failure of the school to create a positive learning community. Parents complained about interactive troubles, noise and chaos in the classroom, exclusion and bullying. Teachers complained about the impossible task and of not having the required time, skills, knowledge and support to successfully include students with special needs.

Even though using the concept of inclusion - and not integration - most of the available Danish studies on inclusion in schools were focused on integration and the question of how many students were enrolled in general versus special education. It is important to state that the debate and all the study results about inclusion referenced so far have concerned the inclusion of students with special needs into general education. So far, this seems to be still the mainstream understanding of the concept of inclusion. However, I will argue that discussing inclusion on these premises masks another dialogue; namely the inclusion of all students into a safe, motivating, inspiring and fulfilling learning community. Thus, there is a need to extend the focus of research in inclusion.

As I shall outline in chapter three, recent research has taken up this question and contributed to understanding inclusion as providing a supportive inclusionary learning environment for all students. At the Danish Ministry of Education, Children and Equity website it is stated that inclusion aims for better teaching and learning for all students, which establishes a conceptual shift. Increased inclusion aims for more qualified education for all students and the Ministry strives towards supporting the conversion towards inclusionary schools for the benefits of all students. Furthermore, they write that research has shown that successful inclusion of all students in general education leads to both social and academic benefits for all students, as long as the teaching is performed appropriately and conducted by skilled teachers.

Thus, failed inclusion is understood as due to poor teacher competencies and the lack of necessary tools, knowledge or skills. Earlier, it was explained and justified with each 
child's special needs. In both cases, the way of thinking is guided by an individual focus that either point at the teachers' or the students' lack of skills. Either way, the importance of how communities are created and shaped through inclusionary and exclusionary processes has not been taken into account or studied. Or put differently, it is time to pay attention to how inclusion and exclusion are created in and through interactions and relationships, which again is to focus on the kinds of and quality of relationships and interactions in schools.

Danish politicians and practitioners still demand knowledge about how to enhance an inclusionary learning environment for all students, and to ensure more students complete elementary schools and proceed to secondary education. It is accompanied by a wish to break the exclusionary trends.

As I am writing these lines, a new research project called Approaching Inclusion is taking its first steps at the Danish University of Pedagogy (DPU). Starting January 1, 2016, and continuing over the next four years, the project will investigate how communities in schools are created and formed. Communities both include and exclude. The project will look at what creates and constitutes inclusive learning environments in schools and how different ways of forming communities constitute different kinds of communities, more or less inclusive. The hypothesis of the project is that focusing on communities of inclusionary and exclusionary processes can provide new knowledge about inclusive learning environments. The project describes that in order to qualify the pedagogical interventions for children and young people in complex learning situations, it is necessary to step further into the specific situations and events within the school communities. It calls for research that can identify the impact from both inclusionary and exclusionary processes in schools. The focus on inclusion must be inherent in every pedagogical action - and understood broadly, and not only as a question of being located within or outside, but on barriers and potentials for active participation in learning communities. In line with such beliefs, I initiated this PhD study back in 2013. As we shall see in chapter three the new understanding of inclusion has many advantages and holds great promise for addressing the inclusion problem.

\section{Dealing with problem behavior in schools}

Haslebo and Lund (2014) argued that turmoil in the classroom and disruptive behavior of various kinds has more or less always been a challenge for school professionals. Plauborg (2010) offered an overview of the field of discipline and punishment in Danish 
Schools. Plauborg (2010) argued that punishment matched the feudal agricultural society, discipline matched the industrial society and that classroom management matched the postmodern knowledge society. According to Plauborg punishment consisted, in earlier times, of physical punishment and humiliation, such as being put in "the doghouse". Students were condemned to be raised properly and suppressed, and it was a common idea, that it was best done by using physical punishment. Plauborg (2010) states that in 1967 physical punishment was made illegal in Danish schools and thirty years later it was forbidden for parents to hit their children. Together with new management techniques punishment was supplemented with rewards, school rules, behavioral expectations, control and monitoring. Plauborg (2010) explained that punishment was replaced by discipline, and the teacher was expected to engage in a friendly, objective and fair manner. Turmoil and disruptive behavior was until about 1970 considered as a discipline problem. With new educational trends in the 1970s and a greater emphasis on democracy in all institutions of society the concept of discipline gained a negative connotation and a more retracted place. It was expected by now, that teaching would be based on students' desires and interests. And if that was not the case, Sigsgaard (2002) argued, teachers used to scold students. Asked the question about what scholding is, he says that. "..it is like hitting with the voice" (p. 59) and that it hardly happens intentionally, but in the absence of better tools. Sigsgaard (2002) stated that no teachers or educators had good things to say about scolding, and no one embarked on an educational training to get the opportunities and rights to scold children. Nevertheless, Sigsgaard (2002) stated based on his examination of a number of studies from different countries that scolding was widely used and more the rule than the exception. Thus, Sigsgaard (2002) claimed that research and practical everyday experience showed that scolding was very unlikely to have any positive effect. Students continued to do what they were scolded for, and they learned something completely different than what was the intention. As the author pointed out, scolding is such an everyday phenomenon that, apparently, it is not necessary to provide educational justifications for its use.

Haslebo and Lund (2014) argued that in the 1990s new ideas emerged on how turmoil and disturbances during lessons could be prevented. The teacher should not only teach students in classrooms, but also act as the leader of the class community, the purpose of so-called classroom management. Bang-Larsen, Bang-Larsen and Rasmussen (2000) introduced the concept of classroom management as an approach and a tool that teachers could use to create a good environment for teaching and learning. Krejsler and Moos 
(2008) stated that the original ideas were primarily inspired by behavioral psychology and later supplemented with ideas from humanistic psychology and systemic thinking.

Haslebo and Lund (2014) claimed that turmoil and disturbances, trouble, banter and chatter, running around during teaching, howls and screams were urgent problems that created frustrations both for teachers and students. Fullan (1991) stated that international studies have shown that turmoil and disturbances during lessons are the second largest stressor for teachers. Haslebo and Lund (2014) argued that the understanding of the teaching profession has been expanded, so that in addition to being highly skilled and master many teaching methods, the teacher had to be able to handle all the other challenges that were pressing in a regular school day, including obtaining peace and concentration during lessons, which required new practices. Bang-Larsen and Bang-Larsen (2012) presented classroom management as a positive approach, primarily to prevent turmoil and disturbances during lessons:

...by creating effective positive learning methods (positive lessons) to establish a good learning environment in the classroom the teachers are largely free from using energy on the time-consuming job of disciplining students: the teacher can then use his energy to complete his teaching and support and help every student.

(p. 10. My own translation)

Classroom management within this understanding was based on the assumption that behavior that was rewarded became amplified and habitual, while behavior that was not rewarded eventually would disappear. Interestingly punitive practices or approaches were not recommended. Consequences were understood positively as something to do in order to reward desirable actions and it was recommended directly not to use negative disciplinary practices. The efforts of teachers were directed towards building a good learning environment and positive relationships between teachers and students. BangLarsen, Bang-Larsen and Rasmussen (2000) emphasized that classroom management was a good tool to create a positive and appreciative learning environment and an inclusive class community. Thus it was linked with both appreciation and inclusion. They wrote almost nothing about consequences when students do not follow the rules, but it was noted, however, that the expulsion from the classroom may be considered, but in that case it must appear as the child's choice, "It is very important to your future relationship that the student understands, that it is his choice to leave to classroom" (p. 30, my translation). 
In this understanding of classroom management, the emphasis was placed on preventing turmoil by using positive consequences. This was in sharp contrast to a contemporary guidance from the Committee on discipline, good behavior and bullying in schools (Undervisningsministeriet, 2006). The guide was a clear recommendation of discipline, which was seen as the means to create security, democratic education and respect for the school and the teacher's work. It was argued that disciplinary methods were to be deployed quickly and consistently, whenever students violated the rules and exhibited bad behavior. The instruction guide presented results from a study conducted by the organization Skole og Samfund (School and Society) in 2005 that showed how frequently various types of sanctions had been used in Danish schools (Skole og Samfund, 2005). In the instruction guide a commentary on the study said that sanctions were not used frequently enough and that teachers and schools, "should never ignore behavior in which a student hurts other students or interferes with other students' right to learn" (Ministry of Education, 2006 , p. 18). The instruction guide only gave two options with this comment: either ignore or give sanctions and, according to the Ministry, ignoring was not recommended. Then, what was left for school professionals was to make use of sanctions. The instruction guide then listed a long series of sanctions. For each sanction it was specified what kind of bad behavior justified its use. The first penalty was to be put outside the door. It was argued that this may be relevant if the student disrupted the teacher during the teaching, used crude language, disparaged others or bothered other students. This was the mildest sanction. Next came the penalty to be followed by a school professional (a playground guard) during recess and not being allowed to play with others. Then came detention and the like, up until in-school suspension, suspension, or final expulsion from the school. The instruction guide made a point of describing existing sanctions practice and recommended more of the same. There were no references to research or studies that justified the use of sanctions to reduce turmoil and bullying. From a social constructionist viewpoint, neither of the two options were particularly useful or helpful for teachers or students. Neither of them developed and strengthened relationships, entailed dialogue and learning, or positioned students as knowledgeable and as part of a collaborative school community (Haslebo \& Lund, 2014).

Three years later, a notice on the promotion of good order in the school that is fully in line with the instruction guide was published (Notice no. 593 of June 24, 2009). This identifies the actions that could be used against students "who do not comply with school rules, safety rules or otherwise common standards for good conduct" (Notice no. 593 of 
June $24,2009, \S 6)$. It included actions such as detention, suspension from class for up to one week, transfer to parallel classes, and the like, as well as described under what conditions these actions could be taken.

Thus, sanctioning and punishing in schools are not just rooted in traditions, but also were recommended in recent instructions and recommendations. There were probably large differences between schools and between teachers in terms of how well they knew these official recommendations and how they used them. Nevertheless teachers and schools were left with very poor guidance on how to handle turmoil in ways that were inclusive, strengthening of relationships and helpful for the learning environment.

In the study conducted by Skole og Samfund (2005) it was found that the most frequently used sanctions were to send a student to the principal's office or to send a letter to the parents. Petersen (2013) described her first experiences as a school principal and how students every day sat outside her office waiting for her to find time to scold them out, because of all sorts of misbehavior. They had disturbed the teaching, forgotten their books, or not done their homework or had been "naughty" otherwise. This traffic took place in a Danish public school in 2011. The school principal perceived this practice as systematic exclusion and called on the teachers to find better solutions in their direct contact with students. It proved to be very difficult to change this practice, because the principal's decision challenged the individual-, problem- and deficit- focused thinking that was so dominant at this school.

Alenkær (2008) and Haslebo and Lund (2014) explicitly considered how classroom management could promote inclusion, although with slightly different emphasis. Alenkær (2008) and Haslebo and Lund (2014) pointed out that negative or punitive classroom management risked setting in motion exclusionary practices. However, Alenkær (2008) suggested structures, school rules, and integrating student's perspectives to develop an inclusive school climate, while Haslebo and Lund (2014) pointed to the importance of developing relationships, being attentive and responsive to positioning, and mastering mediation skills. Thus, responses to problem behavior such as through classroom management could influence inclusionary and exclusionary processes in schools, for better or worse. Often responding to problem behavior in schools involved collaboration with the families.

\section{School-family collaboration}


In this section, I wish to elucidate some dilemmas and discourses in school-family collaboration. First, I will briefly explain the foundation for school-family-collaboration. Secondly, I touch upon how basic assumptions around school-family-collaboration have changed over time.

In Denmark school-family collaboration is prescribed by law. It was first enrolled in a public school mission statement in 1975, which in $\S 2$ was stated: “The Danish public school is obliged to cooperate with parents to give students the opportunity to acquire knowledge, skills, working methods and forms of expression, which assist and support the versatile development of the individual student" (Knudsen, 2010, p. 74). School-family collaboration has been explored and questioned many times since both in terms of how this collaboration was to be conceived and how it was performed in order to ensure an equal partnership between families and schools. Collaboration today comprises a multiplicity of activities, ranging from parents' school boards, parents' councils, parents' meetings, small talks on a daily basis, email-correspondence, telephone calls, and meetings with the principal and teachers around special situations. For the quality and implications of school-family collaboration, both everyday communication and more formal collaboration were to be taken into account. When focusing on the longitudinal cooperation around a difficult situation, such as interactive troubles, the importance of the quality of the collaboration and communication increased immensely, since so much more was at stake.

At the Ministry of Children and Education's website, it says that parental involvement and parental influence is of great importance in order to create good school days, rich in learning for students. Furthermore, one can read that good school-family collaboration creates good conditions for the individual student's learning and wellbeing as well as for the learning environment in the classroom. Schools are expected to develop a strategy for school-family cooperation, which should aim to give parents an active role in enhancing their child's schooling. Finally, it is imposed on schools, that students and parents are informed on a regular basis about how teachers' perceive their child's learning and wellbeing in school and how they benefit from schooling.

Knudsen (2010) offered a solid overview of school-parent collaboration. Using discourse analysis and everyday life studies she aimed to make explicit what had not been questioned yet and what might be different, and had offered useful knowledge in this regard pointing to the fact that school-family collaboration unfolds differently depending on the way of thinking used by school professionals. Looking at discourses is a way to discover some of the assumptions taken for granted. Knudsen $(2008 ; 2010)$ illustrated how it was 
possible to identify a series of discourses that cast a different light on the interaction between schools and families. As she pointed out, the interaction and collaboration could be understood in various ways - and the way chosen influenced how communication and events unfolded.

Haslebo and Haslebo (2007) argued that a discourse could be understood as a cluster of statements, assumptions, and metaphors, which represented a particular understanding of reality, created certain positions and defined a range of opportunities for action.

Discourses are embedded in the dominant culture and contain elements that are often not articulated. It required a special effort to discover the discourses that directed thoughts and actions. The discourse analysis that Knudsen $(2008 ; 2010)$ had done was based on three sources of data that altogether shed very different light and meaning upon the interactions between schools and families. One source stemmed from documents on practical guidance such as laws, ministerial orders, guidelines, instructions and literature from a period of 100 years. Another source stemmed from observations and interviews at two schools, and the third source stemmed from concrete initiatives; the annual school-family conversations, reprimands at the principal's office, training in conducting The Difficult Conversation, Family classes and The Game of Responsibility. On the basis of these data, Knudsen identified five discourses in school-family collaboration; the discourse of duty, the discourse of backing up, the discourse of participation, the discourse of conversion and the discourse of responsibility. All existed in daily practices and in various combinations, and the study showed that these discourses historically emerged in chronological order. A discourse included not just assumptions concerning, for example, schools and families, but also positions the parties and defines standards of conduct. Each discourse has its standards, often not in accordance with the standards of another discourse. If two or more discourses are in play, it could further complicate the cooperation. As Knudsen (2010) points out, each discourse offers a certain meaning, but is not necessarily easy to act upon and there are specific dilemmas for teachers and parents in relation to each discourse and combination of discourses. In the following I will just highlight what Knudsen (2010) calls the three most dominating discourses.

The fulcrum of the discourse of duty is compulsory education. From the early 1800 s and over the subsequent 150 years, parents' responsibility was limited to making sure that their children were taught, either at home or in school. If the children attended school, parents should make sure to "deliver a clean child ready for teaching and discipline in the school" (p. 63). Parents could be fined, if they kept the child at home, for example to work. 
To "pay a fine" as a penalty for truancy was abolished in 1970, but as Kryger \& Ravn (2007) argued the praxis lives on in new forms, such as in the recent law on increased parental responsibility that was politically decided in 2006. According to this law, it was possible for a municipality to provide parenting orders for those parents who failed to ensure that their child came to school. If the order did not have the desired effect, the municipality should assess whether there were special circumstances that could excuse the wrongdoing. Were this not the case, the municipality could refuse to pay child-family allowance.

Discipline, including physical punishments, was within the discourse of duty both a right and a duty of the school. The relationship between school and home was primarily legally determined. In the first half of the twentieth century, however, new methods of interaction were developed, such as visiting families at home and inviting parents to attend classes, morning singing and parent meetings. The discourse of duty still lives and forms the basis for the continued use of sanctions, which today has the characteristics of various forms of exclusion, that parents are expected to give approval to. As Haslebo and Lund (2014) argued, unfortunately the discourse of duty positions a teacher as a prosecutor, a defender, a judge of children's misdeeds and as the one to carry out the sentence. This requires great balancing for the teachers to discipline and punish students without damaging the relationship and losing legitimacy.

The next discourse is the discourse of backing up that came along in the 1950s. The school is now seen as a state institution, which has the task of making the child a citizen and a happy person. The school must inform parents about child development and the parents should show confidence in and support for the school's descriptions, assessments and decisions regarding their child. The school's staff is perceived as professionals and as able to provide objective knowledge of the child. Believing in objective knowledge may lead to disputes about who has the right to define "reality". When schools and families hold different perspectives and schools claim to hold the "true picture", knowledge of parents about their child is judged out of the game. As Knudsen (2010) shows, within this discourse, parents' knowledge cannot be made to count as it is considered subjective and selfish, because the logic is that parents are only focused on their own child. Hence, parents are positioned as either "critical and troublesome" or "cooperative". They are, from the school's perspective, "critical and troublesome" if they have a different view of the child and "cooperative" if they tractably accept the school's description. This puts parents in a loyalty bind. If they submit to the teachers' descriptions (but do not agree), they can then abandon their own child. If they support the child, they challenge the teachers' authority as the 
experts. For teachers, it is not easy to navigate this discourse either. Teachers must both identify improvement opportunities for the child and express themselves positively to motivate the student - without seeming untrustworthy. The annual school-family conversation often takes place within this discourse of backing up.

The third discourse is the discourse of responsibility which developed from 1990. Within this discourse, school and family floated closer together and conceptions about learning changed. Learning became not just something that took place at school and in the classroom, but also in the family. The family was responsible for the child's overall learning and must now contribute to the school to make it a good learning environment. The school should encourage parents to consider how to support progress in their child's learning and the class community. Parental responsibility became unclear and borderless. Knudsen (2010) states that:

... within the discourse of responsibility parents have an obligation to voluntarily take responsibility - even in areas where they do not have much direct impact, for example on the level of respect at the school, on their child's behavior in class, and on other families' well-being.

(pp. 105-106, my translation)

As Knudsen (2010) explained, parents were expected to take these responsibilities, but have no influence on teacher education and teaching practices in class. Parents were expected to solve their child's problems in the classroom from home, while not interfering with the teacher's direct interaction with their child. This became a dilemma for both parties and impeded meaningful conversations because parents were expected to contribute to a good learning environment at the school, but not considered as holding relevant knowledge and legitimate points of view about what was happening at school. Therefore, this discourse posed dilemmas and thus great potential for conflict.

Knudsen (2010) and Haslebo and Lund (2014) argued that it is still a central question how the interaction between schools and families should be conducted, as well as what the schools could expect from parents and what parents could expect from the school. The answers to these questions have changed over time. The key questions have changed as well. The question, "How do we get the parents to take on their responsibility?" as the Globalization Council asked in 2005 would barely be raised just ten years earlier. Today it 
still seems an entirely natural question, because it is embedded in the discourse of responsibility.

As elaborated in the introduction, the problem of interactive trouble might be regarded in quite different ways. I have used the word problem in relation to this thesis several times by now, but wish to unsettle the common meaning of the term. What is regarded the problem might be various things ranging from critical and troublesome parents, misbehaving kids, unbearable tasks for schools to carry, or the lack of decency in educational policy. But for school professionals actualizing deficit thinking, the problem might not be seen as a problem at all, but as an integral part of the job itself. In fact, as Knudsen (2007) and Højholt (2006) argued, for many school professionals having "unpleasant" conversations with students and parents in dealing with what they might see as (interactive) troubles at school is in many cases something they are trained for.

Knudsen (2007) illustrates how teachers are systematically trained to engage in "difficult conversations" with parents and, therefore, teachers do not talk about difficult school-family collaboration as an essential institutional problem with serious potential social consequences. Nevertheless it still might be seen as such from another perspective. Haslebo and Lund (2014) claimed that due to the same argument, school professionals often did not discover the basic assumptions underlying the emergence of the problem, nor that it could be very different. Knudsen (2007) documented training at a school in handling difficult conversations with parents and showed how the training began with the teachers categorizing various types of difficult parents. The teachers identified and made use of five categories: the extremely well-prepared, the selfish, the elusive, the aggressive and the disagreeing parents. During the training the teachers agreed that the most difficult type to handle is the extremely well-prepared. As the researcher explained, extremely wellprepared parents directed a triple criticism towards the school: 1 . they alleged that their experience as parents counts as much as the teachers, 2 . they drew on professional knowledge, and 3. they did not accept that teachers' standards for good student behavior were supreme.

Haslebo and Lund (2014) argued that facing such parents, teachers were likely to be positioned in a weaker position. If their monopoly on objective knowledge was contested, they did not have much to fall back on, at least not within the available discourse. The scope for action narrowed to rejecting the parents' suggestions and questions. But not only the possibilities of the teachers narrowed, also the parents' influence decreased. The common track became more and more narrow. Teachers' rejections of proposals and 
suggestions reinforced the positioning of the parents as, not just extremely well-prepared, but extremely difficult. As Knudsen (2007) outlined, communication was brought to an end or developed into a head-on collision, where the school expected the parents to solve a problem at home, and the parents expected the school to solve the problem at school.

Haslebo and Lund (2014) argued that the available discourses are based on individualistic thinking. The two parties were caught up in a pattern where their scope for action was getting smaller, and the breakdown of communication and exclusion of the child became a menacing and nearby possibility. When schools operated within these discourses, it became difficult and sometimes impossible for the school to fulfill their statutory responsibility to cooperate with parents. Here it is important to emphasize that the school staff are the professionals, and thus they have a greater responsibility to establish cooperation that is good for both parties. Therefore, it is incomprehensible that there is no formal training for teachers in having joyful, learning-rich and fruitful conversations with parents and students.

Quite formally, the school has the power to make scores of decisions that affect students and parents every day: organizing classes, scheduling the allocation of teachers for each class, homework, teaching quality, practices of inclusion, dealing with conflicts, organizing the school year with student conversations, school-home interviews, parentteacher meetings, excursions, school camps, and so on. All these decisions help to define the framework for interactions that take place between school and home, between parents and between parents and students. It is not only these conditions that determine how communication and cooperation will take place but, as elaborated, these conditions are highly determined by the available discourses.

As Knudsen (2010) wrote, there were recurring experiences in which parents "protested", "complained", "expressed distrust" and were not compliant with their designated positions and expectations. (Freeman (2010) found a similar phenomenon and called it resistance). Knudsen found that parents experienced teachers and principals as not listening. Both parties experienced that something was wrong with the other party.

It seems that an equal partnership between parents and teachers cannot be achieved within the available discourses. So where does all this leave the students? Dannesboe et al. (2012) pointed out it was mainly the school's and teachers' perspectives that are described in research literature and public debate. Thus they decided to remedy that voices of parents and students are rarely heard. Based on their research on student 
voices in 0th grade, fourth grade and sixth grade, they found many interesting results from which I will mention two.

First, Dannesboe et al. (2012) concluded that it was a recurring finding that students were passive participants in school-home conversations. "They leave it largely to adults to come to terms on how they are as students. They maintain the attitude that the categorizations of them done by the adults are not relevant to them" (p. 137). However, it became difficult to keep this distance when their personal qualities were articulated in negative ways. Here students seemed directly uncomfortable, insecure and nervous. Secondly, the researchers documented that conversations have a hierarchical structure with the teachers at the top, then the parents and the kids at the bottom. Everyone contributed imperceptibly to this structure. Students did so in an attempt to escape being labeled. The researchers ended up with the very important question about what caused parents to participate in this tradition for which main aim seems to be to put a label on the child, using only very few categories that were chosen by the teachers. Parents rarely got the opportunity to come up with their perspectives, and rarely got information about learning progress, friendships, academic interests, potentials or hopes for the future of their child. For children and adolescents, school-family conversations were often something that just needed to be gotten over with. Dannesboe el al. (2012) argued that many parents showed up at school, just because they did not feel they had a choice.

Thus school-family collaboration is packed with dilemmas, discrepencies and impediments. However, it is widely agreed that a well-functioning collaboration is necessary for students learning and wellbeing in schools. Thus, the contemporary conclusion is that there is potential to improve this relationship, and that the families in many cases are interested in offering their assistance to schools concerning the moral purpose of education.

\section{The moral purpose of education}

Barber and Fullan (2005) state that, in regard to schools, the moral purpose means having a commitment to making a difference in the lives and outcomes of students as a result of their experiences at school. They explain that, "the central moral purpose consists of constantly improving student achievement and ensuring that achievement gaps, wherever they exist, are narrowed" (p. 1). According to Barber and Fullan (2005) moral purpose also involves treating people with respect and contributing to the social environment. For a school to achieve this, there needs to be a shared commitment to 
explicit values and underlying epistemology (Bezzina, 2007). Barber and Fullan (2005) claim, that moral purpose is the link between systems thinking and sustainability and that it is not possible to move substantially toward sustainability in the absence of widely-shared moral purpose.

Moving towards a social constructionist perspective, schooling might be regarded as a relational, social and cultural construction, in which a number of more or less explicit basic assumptions set the stage for practices, communication and interaction. According to this approach, there are many ways in which a school can be conceptualized. Inspired by social constructionist organizational theory, Fullan (2012) and Haslebo and Lund (2014) argued that schools could be regarded as organizations or working communities inhabited by organizational members (teachers, other professionals, students and their families) sharing the common purpose of the organization and thus could coordinate actions and meaning through communication, which both constituted and warranted the organization. From this perspective, it is important to continuously consider and reconsider the moral purpose in order for organizational members to coordinate and collaborate.

Deleuze's (1994) perception of education is, like his perception of creativity, of something or someone becoming different. Smyth and Hattam (2004) talked about the transistion into adulthood and thus education is both about learning outcomes, wellbeing and the becoming of somebody (different). As such the moral purpose of schooling is to develop and make use of the potentiality of every student's becoming someone differentunderstood as a capable, wise, engaged, recognized, acknowledged and responsible member of the school community.

Biesta (2014) was also concerned about becoming someone through schooling. He claimed that education was fundamentally risky. If we abandon all the risk in education while understanding risk as what potentially opens the future for the child - we reduce the future of the child. For Biesta, opening up the future for the child is what he calls grownupness (formation to adulthood). According to Biesta, the reason we educate is to help other people to be in the world in an adult manner (a grown-up way), which is different than an infantile way. Biesta argued that infantile behavior responds to everything from a narrow frame of reference. If the world is not just the way you want, you get angry or frustrated, while you want to work yourself out of anger and frustration if you have realized that it is good to be in the world in an adult manner. Biesta continued that this insight was important, because otherwise there was a danger that people develop destructive forms of expression. Biesta argued that an important theme and trend of our time is that we destroy 
what does not fit into our picture of the world or our perception of what other people should be. To Biesta there is a world outside of ourselves, which is not only our own projection. It is this realization we must reach for. For Biesta (2014) adulthood is a matter of democracy, the environment and caring for each other.

Winslade and Williams (2012) argued that schools were a microcosm of the rest of society and state that education is fundamentally preparing for democracy. Schools are places where children should learn how to get along with others and how to handle differences with others in inclusive ways. Therefore, they argued, schools have to scaffold the development of the attitudes and practices that will sustain democracy. With reference to the implicit hidden curriculum of schooling, Winslade and Williams (2012) pleaded that they be made explicit;

... democracy ... is ... a promise of a future ... (that) involves ... staying in conversation with people, rather than shutting down conversation in favor of monological thinking. By contrast dialogical thinking is endlessly creative, always producing new forms of difference through remaining open to multiple perspectives.

Thus Winslade and Williams emphasized that staying in conversation, being in dialogue and being open to multiple perspectives were pivotal to maintaining a democratic society, and thus important to the purpose of education. McNamee and Gergen (2008) argued for a relational ethic in regard to education, where more attention would be paid towards how actions and interactions could be carried out in ways that positively affect relationships, positions and possibilities. The emphasis was put on the moral obligation or the ethical responsibility to take into account the becoming of others. Education is also about trying to develop and enhance relational thinking in practice. McAdam and Lang (2010) stated that the relational responsibility of a teacher was so much more than covering subject knowledge and facts. McAdam and Lang (2009) said that the most central task for schools was better described as creating joy and curiosity through teaching and learning, as well as to teach and train students to live together in appreciative ways (p. 11).

Winslade and Williams (2012) state that any group of people in any part of the world has experiences with conflict, and thus schools do too. Conflict is inevitable and the aim is not a conflict-free school environment, but an environment where conflicts are managed effectively, so that differences are respected, competing cultural perspectives valued, and 
individual students, teachers and parents are heard and included in the conversation - all so that educational activity can proceed. By contrast, Winslade and Williams suggest that conflicts are:

... often managed poorly. Constructive ways of moving forward are frequently not found ... pain is produced. Much energy is expended thinking about conflict, which could be harnessed for other purposes ... Actually, handling conflict constructively is challenging. We learn how to do it in our families or schools often haphazardly. There is seldom a systematic curriculum for learning to get on with others and resolve differences.

Students, therefore, do not always learn how to handle conflict. Sometimes they are lectured or advised to do it better but often without being shown or given the chance to practice the specific skills of doing so. As Winslade and Williams state, "What is needed is an explicit recognition that this (conflict and difference) is all normal and that schools are prepared to handle it" (p. 2). Handling it involves established procedures for people to assert different perspectives: influence each other, listen, and reach resolutions that incorporate multiple perspectives, rather than imposing singular ones. School professionals do not always know what the best solutions are, so effective conflict management requires attention to the design of processes for constructively handling differences and sometimes outbreaks of conflict. According to the authors, what is needed for a school to become serious about creating a climate free of violence and where conflict is handled constructively is to use a comprehensive range of approaches on the basis of thoughtful decision-making about what is most appropriate in a particular situation. They conclude, that there is no magic silver bullet that will transform a school climate with one intervention, and hence, they advocate having a range of approaches, from which the most appropriate response needs to be selected for each situation.

Winslade and Williams addressed the problem of many young people finding themselves alienated from learning opportunities by experiencing repeated failure in school or they are so often in trouble that they have learned to switch off to the concerns of authorities and are thus alienated from the official purpose of schooling (p. 11). Alienation is a common experience of school that plays a role in the production of conflict. It results from processes of social exclusion or marginalization. If we take it seriously, these are implications for conflict resolution. Processes of conflict resolution should seek to knit 
people back into the social fabric. They should work to be inclusive rather than exclusive, even of those who make this hard. Because it helps build the foundation for a democratic society, responses to interactive troubles in schools should be relational, rather than focused on the individual as a site of pathology (p. 11).

In the next section, I shall address the significance of relationships in education.

\section{The importance of relationships in schools}

A large body of research on educational practices offers ideas for how we can improve schooling. From looking at the research about the impact of relationships on students' learning, performance, well-being and enjoyment of school, a consistent message appears, namely that relationships matter. One important source is the work of Hattie (2009) that presented the results of fifteen years of research and synthesized 800 metaanalyses with the goal of identifying the factors that have the greatest positive impact on students' learning and performance in school. Hattie (2009) challenged habitual thinking and myths in favour of identifying the impacts of different factors on students' learning. He found that many of the factors we assume are important have no effect whatsoever. For example, a range of factors concerning the size and structure of the school, classroom size, number of parallel classes, funding and so on, which may have a positive impact on working conditions for the staff but have little impact on students' leaning and achievement (Hattie, 2011). One surprising conclusion was that there is no major difference among schools, but big differences within individual schools among classes and teachers.

According to the results, the teacher plays the key role in teacher-student relationships, and exercises the most positive factor for students' learning and achievement. Hattie (2009) states that it has a strong positive effect on the students' learning when the teacher develops good relationships, shows respect for what the student brings to the class (from his or her home, culture and friends) and provides a space for acknowledging students' experiences in class. Actually, when students, parents, school leaders and teachers are queried about what they think has the biggest impact on students' learning, everybody, except teachers, point to teacher-student relationships. The teachers on the other hand point to student attitudes and aptitude, the home and working conditions in the school.

Hattie (2009) also found that developing relationships requires skills from teachers, such as listening, empathy, caring and having positive regard for others. Relationships among the students are also very important, with friendships between students being one 
of the strongest factors. Good friendships mean that students help each other, provide support and feedback and make the school a place where the students are happy to come every day. Friendships also make it easier to resolve conflicts, and fewer conflicts improve the students' ability to concentrate and learn. Friendships thus contain important resources for learning, which students who are excluded miss out on.

Further, Hattie (2009) found that low peer acceptance in the classroom was linked to disengagement and lower performance. In extension of this point, it was found that whenever there was a major transition - going from preschool to school, changing to another class or school or when classes were restructured - the main predictive success factor was whether the child made a friend within the first month. A third leading factor is classroom climate and cohesion. To have a positive impact on students' learning, classroom cohesion should describe a situation where everyone - teachers and students - are working towards positive learning gains. Thus, cohesion in this context has to be associated with goal orientation and social support for the learning process. Conversely, a classroom climate characterized by cliques, friction or apathy had a very negative impact on learning. Positive classroom cohesion was associated with a higher likelihood that students would help each other learn and were interested in talking about goals and success criteria for learning, and that there was room for errors and increased feedback. As Hattie (2009) concluded, good classroom cohesion goes hand in hand with positive teacher-student relationships.

However, positive teacher-student relationships, friendships among the students and good classroom cohesion did not emerge automatically, Hattie (2009) argued. Establishing, developing, strengthening, reshaping and re-establishing positive relationships requires skills and commitment. Since teachers are the professionals, it is crucial that they are able to serve as good role models, and that they have the necessary thinking tools and a wide repertoire for action. In other words, the teacher should not merely teach a subject but has to put in a professional relational effort every day.

On the question of how important establishing relationships were, compared to content knowledge, Hattie (2009) had the surprising answer that it had a fairly limited impact on student learning how well the teacher had mastered the content of his or her subject. Of course, a firm knowledge of the content is required, but additional content training is not reflected in improved student achievement. This is puzzling, as Hattie also remarked. Part of the explanation is that many other factors that have a bigger effect, especially, the teacher's teaching strategies, expectations of the students and perceptions of 
teaching, learning and progress (Hattie, 2009). The teacher's interest in the students' progress requires communication and must necessarily be based on positive teacherstudent-relationships, where the teacher sees the learning process from the student's perspective.

As outlined by Hattie (2009), teachers have to see themselves as agents of change who are convinced that all students are capable of learning and making progress. What teachers think, say and do thus has a crucial impact on the students' learning. When students were asked who their best teachers had been, various surveys found that they mentioned teachers who built relationships with students, teachers who helped them find the best ways to learn, and teachers who were willing to explain material and help students with their work.

These research findings are interesting, because they indicate a direction for considerations and identify key points that are important for building relationships in school. Hattie (2009) underscored the need for school professionals to develop relational skills. Many others have reached a similar conclusion, among them Dysseggard et al. (2013) and Nordenbo et al. (2008). In the latter it was found, based on seventy studies on the link between manifest teacher characteristics and student learning, that three characteristics stood out as being particularly important: relational skills, classroom leadership skills and didactic skills. With regard to relational skills, the emphasis in the report was on the teacher's ability to establish positive relationships with individual students and groups of students, which requires the teacher to show respect, tolerance, empathy and interest in relation to the students. Students must be met with respect for their perspectives, their voice and their potential (Nordenbo et al., 2008).

Klinge (2016) also found in her PhD study that the quality of the teacher-student relationship influences the student's academic engagement and outcome, as well as his wellbeing - including levels of stress and self-perceptions - social behaviour, internalization of rules and norms, and self-regulation. In establishing high quality relationships, the teacher's relational competencies are a pivotal factor. Klinge offers an example, where a student in relation to one teacher that in general did not act with relational competence, did not concentrate and was dissatisfied, but in relation to another teacher that showed a high level of relational competence, the same student acted collaboratively and did concentrate. Through interviews with students, Klinge found that students long for the experience of being important to the teacher, both in regards to the teaching context, but also in regards to an existential dimension. Being important includes being taken seriously and feeling a 
general human interest. Furthermore, Klinge found, that teachers who were negatively aroused produced actions and communication by which certain students were excluded from the learning community. Negative utterances and scolding were damaging of student motivation, safety and concentration, even for the students who were not scolded.

\section{Beyond Reproduction Theory}

Reproduction theory (Giroux, 2006) and concepts like social legacy are often used to describe how social and psychological problems are inherited between generations, including how children and young people from socially vulnerable families are at risk of social marginalization. Traditionally, the focus has been on how social marginalization is linked to conditions in the social and family background. For example, neglect in childhood and difficult family situations including psycho-social problems of parents, increase children's risk of social exclusion later in life.

Critics of the concept of social legacy have however pointed out that the concept gives a far too deterministic understanding of the links between social and psychological problems in family background and the risk of social marginalization (Ejrnæs, 2011; Larsen, $2005 ; 2009)$. Ejrnæs (2011) highlighted that it was far from all children and young people from socially disadvantaged families who themselves developed psychosocial problems. On the other hand, his research showed that there were children and young people from families, that could not be characterized as socially vulnerable, that developed social and mental health problems over a lifespan.

These claims were supported by a study from Det National forskningscenter for Velfærd $^{6}$ (SFI) called Familiebaggrund og social marginalisering i Danmark. En registerbaseret afdækning ${ }^{7}$ (Benjaminsen et al., 2015). The study was based on a comprehensive database in the form of individual register data for 4,378,227 persons from the age of eighteen and above on 1 January 2011. Benjaminsen et al. were concerned with what characterized the interaction between family background and the risk of social marginalization, and how different forms of social marginalization played together, and what types of families, socially marginalized young people came from.

The results were surprising, since the scientists found that a significant part of the marginalized group comes from what is broadly characterized as "the middle class", where

\footnotetext{
${ }^{6}$ In English: The Danish National Center for Social Research

${ }^{7}$ In English: Family background and social marginalization in Denmark. A register-based mapping.
} 
the parents were both well-educated and in employment. In fact, half of the young people who were in a socially marginalized situation did not have a parental background affected by the risk factors that are used to define social marginalization. However, there was a higher risk of social marginalization among young people from families where the parents had social and psychological problems. The study stated that the concept of reproduction theory (social legacy) should be understood as much more nuanced and used with caution. This not only challenged the commonly held belief in the social field and in the public debate in general and schools in particular, that vulnerable young people primarily come from socially vulnerable families, but also raised new questions. If a significant group among the marginalized young people come from "the middle class" with no strong predictors of social marginalization, how come they were marginalized anyhow?

Benjaminsen et al. (2015) stated, that there was no such thing as automatic transmission of social and psychological problems between generations and thus, the study offered the important and encouraging finding that many young people from vulnerable families, despite the problems in their family, did not show signs of social marginalization later in life, and many managed to get an education and a job. The Benjaminsen et al. study (2015) supports the results of the research by Ejrnæs (2011), that the concepts of reproduction theory have been understood in a far too deterministic way. Instead, they suggest that social research and educational development should replace the idea of reproduction theory with a stronger concept - theoretically and empirically - to describe the differences in risk factors and life chances associated with different family backgrounds. However, their analysis show that social marginalization for young people impairs both educational and employment chances. Marginalized youth are significantly less educated than the majority of adolescents and a large part of marginalized young people leave school early. Most of them do not finish higher education. About two-thirds of marginalized young people do not get a vocational education program, regardless of the parents' education. Marginalized youth with lowly-educated parents are leaving school earlier than the marginalized youth with parents that are highly-educated. At the same time, marginalized groups are considerably more poorly positioned in the labor market than other young people. About half of the young people who have been affected by social and psychological problems as youth, are at the age of 28 years neither in employment, education or training, and as such they belong to the group in the research literature termed as " NEET " group (Not in Education, Employment or Training). 


\section{Positive and negative pattern breaking}

Elsborg, Hansen \& Hansen (1999), Søgaard (2002) and Ploug (2008) stated that it has been and still is of great interest to focus on how to break the reproduction of social marginalization. According to Søgaard (2002) and Jæger (2003) the focus for research on reproduction theory has mainly been concerned with cases, where socially vulnerable children grow up to be middle class adults, the so-called "pattern breakers". Jæger (2003) argued that one thing that the pattern breaker-research has shown is that in most cases, what seemed to be essential to breaking a pattern of social marginalization was that the child or young person meets another person, for example a teacher or a friend of the family, who sees a potential in the youngster and becomes an important other. Hence, the research suggests that a single strong relationship may be contributing to the child breaking the negative social legacy. Jæger (2003) claims that breaking one's social legacy is often called positive pattern-breaking, because the person breaks out of a negative pattern and creates a more positive life situation. However important knowledge is established, there are still questions to be answered when it comes to a negative pattern-breaking, such as children from middle class families becoming socially marginalized. Benjaminsen et al. argued that we do not know much about how and why this happens. However, it is precisely within this particular field of research, that my study is placed. What I am looking at is the social marginalization and eventually exclusion of middle class students and their families in schools. However, it is a snapshot-picture, and the study cannot say anything about what happens to these young people and their families over a longer lifespan. But as we shall see in chapter 5 it does very clearly indicate what produces the marginalization and exclusion. In the following section we shall go into more detail.

\section{When family background cannot explain social marginalization}

Benjaminsen et al. (2015) also showed that children and young people have resources and skills despite adverse family conditions, which many practices do not take into account. It was also suggested that positive breaking of socially negative patterns could be due to well-targeted social services during childhood, where children's skills and resources were enhanced. Thus, the Benjaminsen et al. study contributes to a deeper understanding of the relation between family background and social marginalization. According to Benjaminsen et al., it is not only family background that affected the paths into 
social marginalization, but other things "outside" the family came into play. What might these things be? As the researchers point out, the study only looks at the relationship between social marginalization and family background and, therefore, did not imply any judgment as to what this "something outside" could be. However, it was suggested to look at where the family meets with the welfare system, in practice, in the form of day care institutions and schools.

Interestingly, Benjaminsen et al. found that young people from middle class families that faced social marginalization dropped out of school before time, but, on the other hand, remained in school longer than young people from the most vulnerable families. Moreover, they first popped up in the social system during late adolescence, and later than other atrisk youth. Thus, the researchers roughly point to circumstances surrounding the youth's schooling as something essential to explaining social marginalization. They suggested that the social and health care systems need to be aware of the various pathways into social exclusion and that there are marginalizing structures in the welfare institutions that endanger not-yet marginalized youth. The researchers indicated the likelihood that what created social marginalization, might take place in the young people's interaction with the school.

Finally, the study showed a thought-provoking schism from interviewing practitioners. In addition to the comprehensive database of individual register data for 4,378,227 persons from age 18, Benjamin et al. conducted 27 interviews with professionals working in municipal services targeted towards marginalized youth. These interviews give a more detailed insight into the mechanisms that existed in the interaction between family background and social marginalization. Even though the majority worked within the traditional understanding of reproduction theory, there were exceptions. Some of the practitioners pointed to the inappropriate tendency to always seek explanations for social exclusion in the young people's family background as something that enhanced social exclusion. With such a precaution, they emphasized that there may be causes of social marginalization outside the family, namely the dominant discourse of reproduction theory in the practices. Hence, some practitioners were aware of the negative constitutive effects of this, while the vast majority was not.

So far, the picture is much more subtle and complex than traditionally assumed. The fact is that there are large differences in family background among marginalized youth, and some practitioners point out that practices must find better ways to involve parents' resources, no matter what these may be, in providing high quality services for all students. 
As such, the studies help go beyond reproduction theory and raise questions of what are contributing to the (re) production of social marginalization. If family background cannot explain the production of social marginalization, we need to find out what does.

\section{Preview of chapter 3}

Chapter three is the literature review part two, where I shall offer an account of the theoretical inspirations for this study. The literature review part two is constructed to help define the research questions presented in chapter one. I shall outline the epistemological framework and identify key concepts, as well as discuss the importance of the work of accredited scholars and researchers within this field. The guiding concept that is my research objective is to argue that the ways in which schools respond to interactive troubles produce much of the difference between inclusion and exclusion. Furthermore, I shall build up the argument that specific kinds of thinking lead to either exclusionary or inclusionary processes, and that the way of thinking is a result of a choice, however predisposed - but not determined - by the dominant assumptions at play. 
Chapter 3

Literature Review

Part two

The field of study 


\section{Introduction}

A literature review addresses the background ideas that inform a research study (Murray, 2002) and embeds the study in particular contexts, research traditions and epistemological philosophies. Key concepts, theories, established knowledge and pivotal research results all together build up the basis on which a study is founded. I have divided the literature review into two parts. Part one concerned the Danish school context and part two concerns theoretical and conceptual considerations. By referencing and discussing what others have said, the literature review positions this study in already ongoing conversations. Working my way through a selective amount of relevant literature, I engage myself in the conversations concerning various issues around schooling, ways of thinking, ways of responding to interactive troubles, home-school-collaboration, social marginalization, reproduction theory, communication studies, exclusionary and inclusionary processes, and epistemological studies. My purpose in this study is to show that the literature contains support for the idea that social exclusionary processes of students and families in schools happen and for the argument that they happen because of the way of thinking and the type of dialogical practices, into which school professionals invite students and families. The particular way of thinking that is most common positions students and families as in deficit, deviant, problematic and bad. It is such positioning that sets in motion a process that both excludes the family from the school and potentially marginalizes the family in the local community. The selection of literature to discuss is based on its relevance to this outline of the problem.

\section{Epistemological considerations}

Epistemology means philosophy of knowledge, and thus it concerns the study of the nature of knowledge and the methods of obtaining it and warranting it (Burr, 1995). KoroLjungberg (2008) claims that epistemological orientation and theoretical perspectives assist researchers in organizing their research and making sense of (..) data (p. 429). Furthermore, she argues that scholars use, read, and interpret theories differently, and cannot conduct research without drawing on theory, if only implicitly. Theory locates researchers within discourses that use specific language and argumentation systems. In addition, theoretical perspectives influence the research process by setting a particular epistemological frame around various stages of the research process (pp. 429). Thus, in this chapter I shall lay out 
the epistemological and ontological perspectives that inform this study of exclusionary processes of students and parents in schools.

As explained by Gergen and Gergen (2004) epistemologies concern convictions and basic assumptions about what is real, good, valid, and what it takes for us to think that we understand something. In the words of Gubrium and Holstein (2008) an epistemology offers specific worldviews and specific ways of thinking, understanding and communicating, as well as of doing and evaluating research. Thus, different epistemologies "make real" different worldviews and different lines of events. Haslebo and Haslebo (2007) argue that epistemologies are socially constructed to serve to organize human meaning-making processes, however in different ways, and they cannot be understood from asking questions like, "Are they right or wrong?" or "Can they be proven?" However, regarding the social worlds people wish to establish, they can be considered and judged more or less helpful. Parker (1992) suggests thinking of things of all kinds as being endowed with one of three object statuses; ontological, epistemological and moral/political. Thus distinctions are to be made in regards to knowledge of knowing, so that different ontological, epistemological and moral/political questions can be raised. Burr (1995) argues that ontology is the study of the nature of things or of existence, while epistemology is the study of the nature of knowledge and knowledge creation. The third object status, that is moral/political, is seen as a special category of things that have epistemological status (such as "intelligence", "race", and "attitudes"). Burr (1995) explains that such "things that can be called into being through discourse, and thus given a reality which can have real effects upon people", for example, subject them to discrimination or give them greater educational opportunities (p. 87). With this in mind the study of exclusionary processes is epistemologically, ontologically and morally/politically interesting. Exclusionary processes are called into being through discourse(s) and thus given a reality that has real effects on people. Before moving on to this, I shall address the problem of finding a way to study such processes in schools.

\section{Understanding schooling}

Smyth and Hattam (2004) argue that understanding schooling is helped by a sociological perspective that situates everyday life within a socio-economic and sociocultural milieu in which subjectivity and context are mutually constitutive and embedded in a dialectical relationship. Freeland (1991) claims, that such a perspective avoids the pitfalls 
of positivist empirical assumptions such as viewing human behavior as the product of isolated individuals making decisions and acting on them. Freeland (1991) warns, however that such a perspective presumes that, "People are born into an already structured society, and that those structures constitute barriers to equitable access and participation well before the child reaches school age" (p. 196).

According to Freeland, by understanding schools from a sociological perspective, we might regard schools as social and cultural locations in which a number of logics or imperatives struggle for significance. The struggles for significance or control of what goes on are played out daily in classrooms and staffrooms, while significant and defining boundaries are organized institutionally and as such are settled, although periodically ( $p$. 19). Hall (1988) argues that settlement contains struggles within manageable limits and can be understood as an unwritten social contract or a historic compromise struck between the different conflicting social interests in society (p. 36). Following on those lines, Smyth \& Hattam (2004) argue that schools are power structures with inequitable power relations and social spaces with implicit rules for inclusion and exclusion (p. 10). I prefer talking about basic assumptions instead of implicit rules, since I think basically those two concepts cover the same kinds of "structures", but that basic assumptions gives a more adequate image. Within this perspective what is implicit (basic assumptions or implicit rules of exclusion and inclusion) - become pivotal in understanding interactive troubles in schools.

However, the sociological perspective points towards socio-economic and sociocultural explanations and may not inquire into how exclusion is created in the moment. First, being preoccupied with social, institutional, cultural and economic structures, can lead to what happens in relationships and communication being overlooked. Secondly, the question of how to move on from understanding (interactive troubles) to creating ways that better develop, enrich and strengthen relationships (amongst school professionals, students and families in difficult situation) may not be addressed. This would require understanding how "power relations" become exclusionary and with what effects. Without this knowledge we risk becoming blind to the issue at hand and changes will be most unlikely to happen at all. Therefore, what is needed is an approach to both understanding exclusionary processes as made in the moment and also envisioning what could be different and how to actually make that difference.

Avoiding the pitfalls of a sociological perspective that Freeland warns about, I wish to search for an epistemological approach that is neither positivist-humanistic, nor merely structuralist, since I fear that both views neglect what is most important here. 
Understanding exclusionary processes by looking at communication and events in schools and how these affect relationships, identities and positions, requires a social constructionist perspective - one in which processes, actions, communication and relationships can be studied. Explaining a social constructionist perspective, Gergen (2009) claims that individuals are relationally intertwined and that it is relationships - and not characteristics of the individual - that make us who we are. Individuals are born into or entered into already existing systems of relationships, positions and cultures. From this understanding it is through paying attention to the systems and development of relationships, that we can come to learn how exclusionary processes evolve. What individuals say, do and think and who they become is roughly constituted and interpreted within existing discourses.

However, even within existing discourses, individuals are also producers of discourse and, therefore, have agency and choice and can exercise resistance. It is within this field of relationships, positioning, choice and effects, that understanding exclusionary processes in schools are helped by a social constructionist perspective.

In the following sections I shall offer an introduction to social constructionism and realism as two very different epistemologies with the purpose of identifying the ways of thinking within each of the two which will serve as my overall theory of understanding. However, it is important to highlight that it is beyond the scope of this study to present a complete and exhaustive review of the area (see Burr, 2003; Gergen, 2009). I shall address the debate around epistemology and ontology, around structure and agency and around moral and political dimensions. Furthermore, I shall present and discuss the theory of coordinated management of meaning, voiced research, exclusion, inclusion, belonging and becoming.

\section{Social constructionism}

Carmargo-Borges and Rasera (2013) describe social constructionism as a postmodern approach to knowledge. As a theory with a philosophical framework, social constructionism focuses on the processes of understanding and addressing social change in postmodern society. It provides alternative philosophical assumptions regarding aspects of the world that are taken-for-granted, and sees things as socially constructed, thereby opening up space for a variety of alternative intelligibilities. Burr (2003) states that social constructionism engages postmodern and poststructuralist debates and has arisen as part of a critical stance against traditional psychology and particularly social psychology, with its 
tendency to take social processes out of context. Gergen (2009) states that social constructionism is not a clearly defined paradigm or school of thought. Rather it is a diverse collection of ideas and concepts from many theorists and practitioners. Burr (1995) offers an extensive elaboration of social constructionism explaining that it developed as a critique of the prevailing paradigm in the human sciences also known as realism, positivism or empiricism.

Gergen and Gergen (2008) explain how social constructionism offers a very different understanding, where "reality" is seen as created by humans in relationships and through communication and closely related to the historical, cultural, social and relational context.

The foundational idea of social constructionism seems simple enough, but it is also profound. Everything we consider real is socially constructed. Or, more dramatically: nothing is real unless people agree that it is. Your skeptical voice might respond, 'You mean that death is not real', or 'the body,' or 'the sun,' or 'this chair' ... and the list goes on. We must be clear on this point. Social constructionists do not say, 'There is nothing,' or 'There is no reality'. The important point is that whenever people define what 'reality' is, they are always speaking from a cultural tradition.

(Gergen \& Gergen, 2008, pp. 10-11)

Gergen and Gergen (2008) argue that social constructionism by its nature defies a single definition. "While social construction is neither authored by any single individual or group, nor singular and unified, there is substantial sharing across communities" (p. 7). The common thread that ties these communities together is the basic idea that "we construct the world" and that language is the primary vehicle through which we make sense of it ( $p$. 8). In her overview of variations within social constructionism, Burr (2003) attempts to illustrate the strands that are common through various social constructionist viewpoints. She highlights four such strands; including social constructionism as a critical stance; as acknowledging historical and cultural specificity; as recognizing that knowledge is sustained by social practices; and as recognizing that knowledge and social action are bound together. Harré and van Langenhove (1999) argue that social constructionism rejects the idea of things having a universal character independent of time and place, as well as rejecting the idea of persons having an essence or inner core (pp. 1-9). It is a showdown of the traditions within individual psychology and psychotherapeutic approaches. 
Pearce (2007) explains the social constructionist perspective as a systemic viewpoint by using the metaphor of a forest. He argues that if you are trying to understand a forest, you cannot just look at one tree. Neither will you understand much about the forest by looking at all the trees one at a time. Instead you need to look at the spaces between trees and the relationships between forests and other ecologies such as grasslands, deserts, farms and cities. "Forests and other complex things like me and you, families, corporations and nations are best understood systemically" (Pearce, 2007, p. 67). From a social constructionist viewpoint all people are seen like trees and forests as interconnected and as each other's prerequisites for being (becoming).

Gergen (Social Construction: Orienting Principles. Thoughts from Kenneth J. Gergen. n.d.) offers an account of the orienting principles of social construction that sums up this perspective as well as set the framework for social constructionist research:

We live in worlds of meaning. We understand and value the world and ourselves in ways that emerge from our personal history and shared culture.

Worlds of meaning are intimately related to action. We act largely in terms of what we interpret to be real, rational, satisfying, and good. Without meaning there would be little worth doing.

Worlds of meaning are constructed within relationships. What we take to be real and rational is given birth in relationships. Without relationship there would be little of meaning.

New worlds of meaning are possible. We are not possessed or determined by the past. We may abandon or dissolve dysfunctional ways of life, and together create alternatives.

To sustain what is valuable, or to create new futures, requires participation in relationships. If we damage or destroy relations, we lose the capacity to sustain a way of life, and to create new futures.

When worlds of meaning intersect, creative outcomes may occur. New forms of relating, new realities, and new possibilities may all emerge.

When worlds of meaning conflict, they may lead to alienation and aggression, thus undermining relations and their creative potential.

Through creative care for relationships, the destructive potentials of conflict may be reduced, or transformed. 
The preceding understandings do not constitute beliefs. They are neither true nor false. They are ways of approaching life that, for many, hold great promise.

(Social Construction: Orienting Principles. Thoughts from Kenneth J. Gergen. n.d.)

With its focus on relational processes and the performative powers of communication, I find social constructionism an appropriate framework for this study. From a social constructionist perspective, what becomes important is not (to understand) the individual or the problem, but to understand (and strengthen) the network of relationships in which individuals interact, relate, communicate and influence each other, and in addition how this affects people's lives or possibilities. Shifting towards a social constructionist perspective has huge implications for school professionals when responding to interactive troubles in schools. Then, for school professionals what is important is to provide possibilities to show students as competent and clever - not the opposite. When thoughts, actions and utterances are realized as influencing the becoming of others, emphasis is put on relational responsibility (see below) and the moral obligation of making agency and participation available to students and parents. Relational responsibility opens up great opportunities to start reflecting on how one's way of thinking and use of language positively or negatively affect the becoming of students.

Social constructionism paves the way for new discoveries that are pivotal to understanding and improving interactions. Where other epistemological theories tend to narrow understandings into conclusions about the way things or persons are, social constructionism tends to broaden the possibilities of understandings in multiple ways.

\section{Variations within social constructionism}

Burr (2003) offers an overview of the range of variations within social constructionism including critical psychology, critical social psychology, discursive psychology, deconstructionism and Foucauldian discursive analysis and constructivism. Burr (2003) explains that discursive psychology is described as micro constructionism, while the work of Foucault is described as macro constructionism concerning wider issues of ideology and power. Micro constructionism has focused more specifically on the details of how language is used as a performative function and has presented an explicit challenge to cognitive psychology; it's separation from social psychology; and its presumption that everyday discourse can be mapped directly onto underlying cognitive representations. 
Edwards and Potter (1992) claim that, "the focus of discursive psychology is on the action orientation of talk and writing ... the primary issue is the social actions, or interactional work, being done in the discourse" (p. 2). With their model of discursive action Edwards and Potter (1992) show how individuals "conduct important psychological business" (p. 3) through their discourse, often presenting information as a report and as factual to infer it's accountability; and in doing so they show how individuals also use rhetorical devices to undermine the viability of alternatives. This is clearly happening in the stories presented in chapter 5 where the school professionals set the context for the school-family interactions and make use of rhetorical devices to undermine possible alternatives, including ideas suggested by the parents. The established context shapes things in certain ways and directions. Edwards and Potter (1992) state that the identification of how individuals do this is a key task for discursive psychology. This is indeed what I am aiming for in this study.

Following on these lines, Turner (2008) claims that social constructionism is a critical theory that shows how social structures are "man-made" rather than immutable conditions, but as he argues, paradoxically various forms of constructionism are deterministic and preclude human agency (p. 493). Turner employs a traditional distinction between agency and structure, in which he identifies six types of constructionist theory. However the typology is not to be understood as definitive or conclusive. Thus, the discussion around epistemology and ontology is also a discussion about structure and agency:

In broad terms, constructionism can produce deterministic ... accounts of the processes by which social reality is constructed without significant reference to human agency; or it can emphasize social agency, by which social reality is constructed without significant reference to the constraints of social structure. This typology of six forms of constructionism identifies two versions of determinism, two forms of nondeterminism, and two schemes that combine agency and structure.

The latter two in Turner's typology are symbolic interactionism and pragmatism, that implicitly embrace the notion of "structuration" in which agency produces structure and structure produces agency. Turner (2008) points out that this epistemological position argues that people construct their own classificatory schemes, but not under conditions of their own choosing. "Actions are never wholly random or individual; they are produced by and shaped through institutionalization" (p. 494). There are various questions to pursue 
from this. Firstly, questions around what is structured, what gets structured and how what gets structured influences agency or the possibilities of agency are highly interesting here. Secondly, there are questions around the institutionalization of actions (or ritualization of actions) can be pursued, and especially questions around how exclusionary processes are reproduced again and again, despite the wish to work inclusively.

With regard to the questions around structure and agency this study has some interesting things to say. In chapter 5 we shall see how what is happening in school-family relations produces exclusionary spirals. Culture, social status, social class, gender and the like are known as highly structuring features but, as I shall argue, they are not final and not the only things at play. From the data we learn that the families are well functioning middle class families and the children are not diagnosed or yet assessed for possible diagnoses. Had they been marginalized in advance, it is likely to assume that their exclusion would be explained by culture, social status, social class, gender or other stigmatizing categories. But since they are middle class and "normal" families social exclusion is not structured in advance and the families are not particularly at risk of being marginalized. However, they are excluded, and from the analysis we come to learn, that something is happening in the interactions that eventually leads to the final exclusion. Even though exclusion is structured in the interaction, agency is also available as we shall see. Parents and students do act and make choices, however their agency is fairly structured (constrained) by the ways of thinking and basic assumptions at play, and thus in fact fairly restricted.

Turner (2008) argues that the debate around social constructionism raises important issues about human agency, the notion of social rights and the assumption that human agents, unlike non-human agents, can be held responsible for their actions (p. 494). A question here is how much humans can be held responsible for their actions? (How much is structure and how much is agency?). And in what ways can they be held responsible for what? In the stories in chapter 5 it is clear that there is considerably agency available, but also that the agency is structured by the background assumptions at play (and less by class, social status and the like). Culture, social status, social class, and gender are presumably also structuring, but it is the interactive dimensions (what is said and done in the moment) that have the strongest structuring effects on agency (available and performed). Thus the study shows that (exclusionary) structures are produced in the making and thus exclusion (that was not presupposed) is made real and has real effects upon people. Therefore, it is possible to say, that the way things gets structured in the moment shapes the possibilities of how agency can be or is performed. On the other hand, the way agency is allowed to be 
performed shapes structures (such as relationships) and processes of becoming worthy citizens (or not).

Turner (2008) argues that structure and agency are mutually constituting, and thus room for agency is always more or less available. With agency people do need to make moral decisions of how to act, respond, claim, invite, listen, and so on. What they do become results from moral choices or questions of morality and thus are also political. What they do and how they do it and what they do not do sets the stage for others to become somebody with agency (or not) and capable (or not) of making (moral) decisions. This leads back to the third object status of Parker (1992) that starts to become clearer. Even though exclusion becomes structured for them, parents and students make decisions about these things, for example, what to say or not to say and how to respond in the line of events, but also when eventually choosing to find another school. As such they do perform agency and make moral decisions. But they are also highly affected by structures produced and the constrained agency and, therefore, responses to interactive troubles in schools are also moral/political issues.

\section{Ontology}

Burr (1995) argues that in the ontological realm are objects which form the material basis of thought - "without bodies and brains thought would not be possible, and the physical and organizational properties of our environment give us something to 'think about'” (p. 87). To Parker, these things are taken to exist independently of human thought processes and language, but, as Burr states, we cannot have direct knowledge of them, because thought necessarily involves a constructive process as, for example, giving meaning to things (p. 86). Parker (1992) suggests extending the category of ontological status to include all the aspects of our physical and social environment that structure action. Burr (1995) stresses that we are born into societies in which life is lived out in a certain kind of physical space, whether this is a house, a school, an office or a factory. These spaces are physically and socially organized in ways that impose constraints on what is possible to say or do. The interesting schism here is the agency/structure question.

\section{Realism}


McNamee and Gergen (1999) state that for centuries realism was the most common, widespread and dominating epistemology in the Western world. Gergen and Gergen (2004) argue that the basic belief in realism is that the reality is "out there" and that - if you choose the right method - you will get the true and right understanding of it. Thus realism rests on the conviction that it is possible to describe "things out there" and their characteristics and workings in an objective and unambiguous way that does not influence the thing studied.

Giroux (2006) talked about the positivist paradigm pushing schools into traditional and conservative curricula and practices. He pointed out that in order to address school improvement we need to address issues (such as economic exploitation, racist oppression and patriarchal gender relations) and relationships that form the sociological context in which schools operate. To do so, he stated, we need to use other ways of thinking, new ways of doing research and of doing education, than the positivist paradigm. However, I have chosen to talk about realism instead of a positivistic paradigm. They are overlapping categories. Following Giroux, however, my point is that dominant assumptions within the realist epistemology are what produces the exclusionary processes.

\section{Deficit-thinking}

Gergen argues (1991) that individual thinking may also be associated with deficit thinking. He identifies the terms which are commonly used in making sense of the self, including low self-esteem, authoritarian, externally controlled, depressed, stressed, identity crisis, anxious, antisocial personality, seasonal affective disorder, self-alienated, posttraumatic stress disorder. His point is this:

Two features of this list are especially noteworthy. First, all these terms have come into common usage only within the present (twentieth) century (several only within the last decade). Second, they are all terms of mental deficit. They discredit the individual, drawing attention to problems, shortcomings, or incapacities. To put more broadly, the vocabulary of human deficit has undergone enormous expansion within the present century. (p. 13)

Thus, deficit thinking entails focusing on individuals, on problems and on deficits. I suspect that the emphasis on deficits in the individual has become the default response that 
assumes the other two. White (1989) argued that listening to people with profound respect involves avoiding deficit thinking, which means taking people seriously, rather than interpreting them in terms of pathology such as mental illness. This means "consistently working from the assumption that, the person is not the problem; the problem is the problem" (p. 6).

Winslade and Williams (2012) argue that deficit thinking in schools has been growing more prevalent and that, "The bigger problem is that the deficit discourse is always reductionistic. It totalizes persons or groups on a narrow range of experience ..." (p. 17). They continue, "The problem of assigning deficits to people lies more in the side effects that are created ... A principle side effect lies in the impact on the individual student's story of themselves. Especially when a deficit description has the authority of a teacher or principal behind it, or even more powerfully, the authority of a doctor or psychologist, it is very hard for a young person to deny" (p. 17).

Skidmore (2004) argues that the psycho-medical paradigm has dominated the educational field far too long and criticizes the "within child deficit-model" (p. 33). Furthermore, he argues, often the situation of interactive troubles is oversimplified (and represented as the problem of one or two individuals), of which the established practices in dealing with interactive troubles are examples.

In situations with bullying, Hansen (2009) warns against the tendency to focus on individual students and their deficits and problems, since it can enhance the bullying pattern, and strengthens the culture amongst school professionals, students and parents, where bullying is both explained and legitimated by individual deficits. As she argues, school professionals, parents and students have the tendency to argue that victims of bullying are 'different' or perhaps even deserve to be bullied. Hansen (2016) calls it the "yes, but-effect" (p. 12) which makes the schools professionals, parents and students naturalize, rationalize and accept the bullying. The logic seems to be: Yes, this (bullying action) was wrong, but on the other hand (s)he (the victim of bullying) is ... (a deficit description). Thus according to Hansen, school professionals, parents and students become blind to the collective character of bullying and instead start creating stories that legitimize the bullying. The individualizing explanatory model results in isolation of the victim, which is a double injustice and very dangerous to the person.

Hansen (2016) calls for a showdown with the "yes, but-effect" and the individualized approach to the problem. She argues for a broader perspective that takes into account the culture of the class community - which the school professionals are also a part of. She 
notices that in classes where the purposes of learning are diffuse, the likelihood that bullying occurs is greater, and furthermore that in classes with bullying there is also a high level of loneliness, anxiety and school disgust ${ }^{8}$ among students. She concludes that bullying is an answer to students' longing for belonging.

Hansen (2016) explains that the job for school professionals is to offer the class community something different to be part of, as an alternative to the bullying community. This is best done through, in and by the teaching settings, such as inspirational and passionate teachers engaging students in inspirational, engaging and co-creative learning experiences. This can outperform the bullying pattern and create a new classroom culture.

Morrison and D'Incau (2000) claim that research on disapproval as a pedagogical tool is used far more often than appreciation, despite the research results stating that disapproval does not have any positive effects on student behavior. Skiba and Peterson (2000) state that research has found a causal linearity between disapproval and increased aggressive and violent student behavior. Metzler, Biglan, Rusby and Sprague (2001) found that when schools do not make use of disapproval as a pedagogical tool, but instead meet students with positive expectation, a series of positive results was discovered; fewer students were sent to the principal's office, antisocial behavior decreased, fewer students vandalized or behaved aggressively, fewer students truanted, took drugs and used alcohol.

Drugli, Larsson, Clifford and Fossum (2007) studied interventions targeted towards children with severe behavioral challenges. They found that children had fewer conflicts when the school professionals managed to establish supportive social relationships, which also enhanced the acceptance from other students. The researchers concluded that interventions that are targeted towards creating positive and supportive relationships between professionals and the child have much better results than interventions that enroll the child in a therapeutic process. The positive results require, however, that the school professional can succeed in giving positive responses instead of focusing on dealing with the aggressive and negative behavior of the child.

Nielsen (2003) argues that for years it has been common practice to categorize students, especially those that challenge the boundaries of the school. It has become traditional to use cognitive tests on students to make their "cognitive profile" (pp. 756-757). The logic here is that when the test results about what is wrong with the individual student are clear, automatically the school professionals know how to organize the teaching in a way

\footnotetext{
${ }^{8}$ School disgust is the translation of the Danish word skolelede. Disgust is a stronger word than dislike, however related.
} 
that is most suitable. Thus, Nielsen argues, the school tries to compensate for deficits in the student, instead of challenging and developing the teaching or the school culture. Thomas \& Loxley (2001) point to this paradox explaining that, "the school's need for order is transformed to an emotional need in the child" (p. 52). It seems as the deficit thinking becomes an overall explanatory model for a range of school problems. Graham (2006) was studying the increase in students diagnosed with ADHD and argued that:

... not blurting out answers in class, remaining in one's seat and being still and quiet are cultural expectations brought about by the advent of mass schooling. For example, if children were still working in the mines at nine years of age their energy levels would be considered a bonus. However, the modern and increasingly unnatural demands of schooling have resulted in the rearticulation of normal childhood exuberance, curiosity and energy as "unnatural". (p. 14).

This categorizing practice in itself is counterproductive to inclusion. Furthermore, because resources are often only provided when a student is diagnosed, diagnosing has become an option for schools to get resources. Despite the very good reasons for this, it also has a backlash, because school professionals and families are encouraged to try get the child diagnosed in order to get access to resources. Thomas \& Loxley (2001) point out that this kind of thinking implicitly leads to categorization and segregation.

Having stated the negative constitutive effects of deficit thinking it is relevant to ask what alternative ways of thinking there might be. Deficit thinking focuses on deficits in the individual who is seen to cause problems. The opposite to such logic would be to focus not on individuals, but on relationships, and on the resources, strengths and possibilities within the network of relationships in order to co-create ways of being (together) that are respectful and fruitful to ongoing everyday life.

\section{Relational thinking}

Focusing on relationships and how people co-create meanings and understandings, as well as form unfolding events, may emphasize finding (re)solutions to problems instead of investigating who is to be blamed for the problems. McNamee and Gergen (1999) argue that a shift is needed away from attributing responsibility and causation to a single 
individual and towards relational responsibility. Due to strong traditions we tend to locate the source to problems within individual minds, acting either individually or collectively. Paradoxically, we are without the conceptual resources to justify such a tradition, and yet the presumption of individual responsibility lends support to a variety of destructive practices. McNamee's and Gergen's criticism is derived from a keen appreciation of the significance of relationships - intimacies, friendships, groups, communities, institutions, and cultures. As they reason, it is out of relationships that we develop meaning, rationalities, the sense of value, moral interest, motivation and so on (p. 10).

Their discontent with the individualistic nature of Western thinking, its negative impact on the individual and society as whole and its ineffectiveness in resolving conflict and argument, is replaced with the notion of relational responsibility. Relational responsibility is described as an understanding of an individual as participating in an open-ended process of exploration via conversation through which relationships can be altered. Burkitt (1999) describes this as a 'generative dance' (p. 74) - a continual and regulated improvisation, in which individuals are constantly repositioning themselves.

Gergen (2009) welcomes an understanding of human beings that is opposite to understanding individual beings as bounded beings with distinct individual consciousness. He elaborates on four centuries of tradition, starting with the Enlightenment and its centering of the individual, independent, sensible and enlightened person; the Self. He wishes to take us to the other side, that is, before the Enlightenment, and there to look for understandings of humans as relationally linked: "... We cannot step out of the relationship. Even in our most private moments we are never alone" (p. 15). Gergen argues that the world's future depends on the extent to which we cherish and protect - not individuals nor groups of individuals - but the continuous process of relating. Gergen speaks of a strong relationality where there is no condition of independence (p. 19). Being relational is also about the ability to find "ways of going on together". Gergen (2015) claims that English has thousands of terms that refer to (and thus make real) individual mental states in a linear mindset and very few that refer to relationships and communication forms. "It is as if we can speak endlessly about the characteristics of individual pawns, rooks, and bishops, but have little way of talking about the game of chess" (p. 98). The word relationalism does not exist in the Danish or English languages, but it seems as a fine equivalent to and response to the concept of individualism. The word relationality, which also does not exist in the Danish language, seems as an equally fine response to the concept of individuality. Wittgenstein (1922) argued that the limits of our language are the limits of our worlds. Without the 
words, how can we imagine what it may mean to respond to interactive troubles from a viewpoint of relationalism?

McNamee and Gergen (1999) suggest the need to extend and modify existing discourses, locating traditions where relationships are already central, and energizing these alternative discourses. Following on those lines, Rifkin (2009) talks about the new empathic approach where "... the traditional assumption that 'knowledge is power' and is used for personal gain is being subsumed by the notion that knowledge is an expression of the shared responsibilities for the collective well-being of humanity and the planet as a whole" (p. 15). Acting wisely is thus to act with relational responsibility. According to Rifkin (2009) it is pivotal for people to develop exquisite skills in problem solution, which require critical, relational and holistic thinking. Such ways of thinking make people discover and understand complicated connections between events, patterns, dynamics, turning points and bifurcation points. Bifurcation points are moments where it is possible to choose different directions both in terms of ways of understanding and ways of acting and where the choices you make will have huge impact on the following events. Traditionally, critical thinking is understood as trying to find and critique problems/theories, their causes and what is wrong with something or someone. But in Rifkin's understanding it may also imply relational, systemic and innovative thinking. Empathy and critical thinking are linked: "The ability to entertain conflicting feelings and thoughts, be comfortable with ambiguity, approach problems from a number of perspectives, and listen to another's point of view are essential emotional building blocks to engage in critical thinking" (2009, p. 604).

From the idea of relational responsibility (dannelse) educators and pedagogues are responsible for the relationships and futures they structure for students. Working with 'relational thinking' is a careful and purposeful way to consider the constitutive effects of the taken-for-granted assumptions at play. To Rifkin, schools have an important role to play. Rather than segregating, excluding, stigmatizing or marginalizing, schools need to become positive forces of change in relation to what kind of society we want in the future:

We live in a world in which getting and holding one another's attention becomes paramount, and relationships of all kinds become central to our existence. Descarte's dictum, "I think, therefore I am" and the humanist psychologist dictum "I participate, therefore I am" have been replaced by a new dictum, "I am connected, therefore I exist. 
To Rifkin schools are much more than places for curriculum studies. He argues that not only are students taught curriculum knowledge, but implicitly they also learn about the correct way to learn and the correct way to study phenomena. He states that the Western traditions of neutral knowledge production have had a huge impact on educational systems:

It is no wonder that generations of school children have found the learning experience to be dispiriting and alienating. They are expected to give up a sense of awe, eliminate passion, become disinterested, and assume the role of a bystander to existence. How would anyone expect to find personal meaning or be engaged in such a world? The scientific method is at odds with virtually everything we know about our nature and nature of the world. It denies the relational aspect of reality, prohibits participation, and makes no room for empathic imagination. Students in effect are asked to become aliens in the world.

(Rifkin, 2009, p. 608)

When turning to relational thinking, communication becomes pivotal, because this is what individuals do when they are in relation. They communicate. This study is undertaking an inquiry of the exclusionary processes in school-family interactions, and thus it necessarily studies relationships and communication.

\section{Taking a communication perspective}

Within the development of social constructionism, stronger emphasis and attention was put on relational processes, such as interaction and communication. Thus communication and social construction are coterminous. Foster and Bochner (2008) argue that to think about, theorize, investigate, write, or perform the constitutive qualities of communication is to inhabit the world of social construction; to root one's work in social construction is to plant one's feet squarely in the world of interactive communication (pp. 85-86.).

In the 1970s and 1980s the social constructionist communication theory coordinated management of meaning (CMM) was developed (Pearce \& Cronen, 1980). Pearce argues (2006) that CMM aimed to look at communication and not just "through" it and, therefore, the CMM-perspective is often referred to as "taking a communication perspective" (p. 5). 
CMM has been called a "multiple tool" useful in every situation, because it enables looking at processes of communication and understanding in more detail how different kinds of communication create different kinds of social worlds (Lund, 2015). Pearce (2004) describes communication as meaning-making and not just as passive receiving of messages. Rather, we live in a life filled with possible potential understandings and one of the challenges in life is to manage those understandings in ways that enable us to make our social worlds coherent and live them with honor and respect. The process of meaning-making is not made in isolation, and we must always and necessarily coordinate the way we manage meaning making with each other. Pearce (2006) explains that CMM is part of a long history in Western intellectual tradition (see Figure 3.1), involving;

... rhetoric; the 'human sciences' in the tradition of Vico; hermeneutics in the tradition of Dilthey, some aspects of phenomenology in the tradition of Heidegger and Husserl; the dialogics of Gadamer; the philosophical therapeutic intervention of Wittgenstein; and the cluster of approaches based in the American pragmatists (James, Dewey, Mead, Cooley), symbolic interactionist, ethnomethodology and social constructionism ... these are the intellectual parents, aunts, uncles and cousins of CMM (p. 4).

Figure 3.1: CMM and its conceptual cousins.

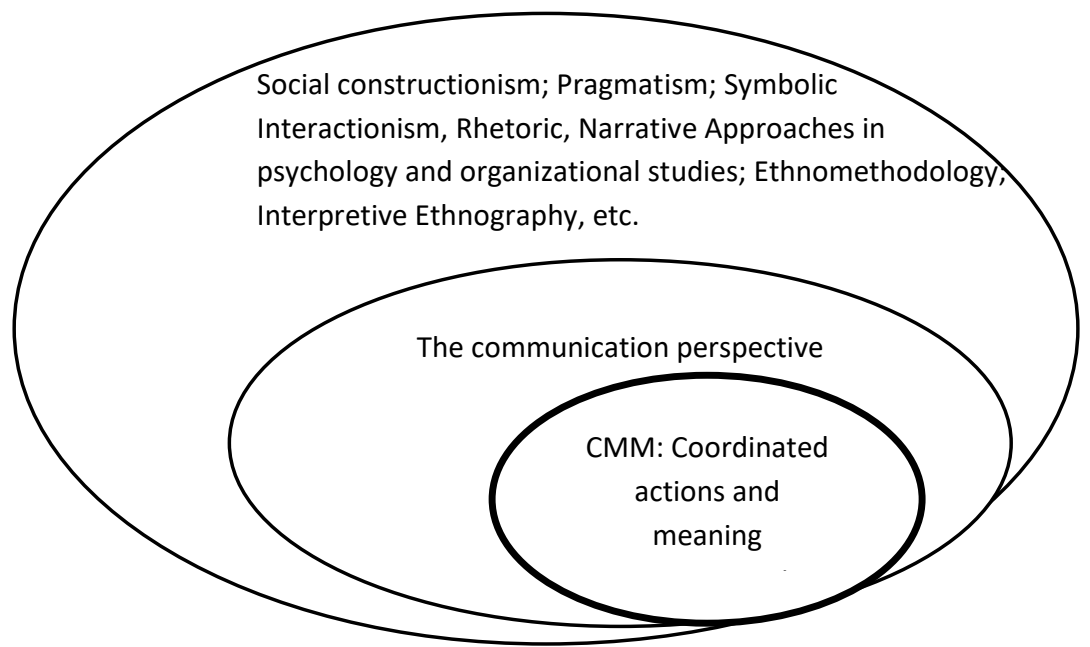

(Pearce, 2006, p. 5) 
CMM names something common to the linguistic turn in philosophy (Ludwig Wittgenstein; Richard Rorty), the emphasis on narrative and discourse in psychology (Ted Sarbin; Rom Harré) and organizational theory (Karl Weick), interpretive traditions in ethnography (Glifford Geertz), and the traditions that study talk itself in sociology, such as symbolic interactionism, ethnomenthodology, and conversation analysis

(Pearce, 2006, p. 5)

\section{Creating better social worlds}

$\mathrm{CMM}$ is based on the belief that communication acts are real and matter to people. Communication acts are the "stuff" of the social worlds in which we live and therefore whether it be compliments, promises, insults and threats - they are not just "about" other people or things, but things in themselves. It matters what people say and do. That is, communication is better understood as ways of doing things, rather than as ways of expressing ourselves or talking about things. According to CMM, patterns of communication are themselves the structures of the social worlds in which we live, and as such they deserve careful investigation. The work of Pearce and Cronen shows how CMM analysis can investigate the creative powers of communication and how this is very rewarding to society in terms of generating potentials for important new insights and knowledge on how to create better social worlds on a practical communicative level (Pearce, 2007). What CMM offers is to look at patterns of communication and ask questions such as: What are we making? How are we making this together? Who are we becoming, while making this? How do make better social worlds? These questions focus the attention towards the processes of the communication, as well as the outcome.

The problem of re-creating unwanted patterns - the so called robust patterns - is highly important. In a study (Cronen, Pearce \& Snavely, 1979) the researchers noted that when certain people got together, they communicated in highly predictable ways that they did not want. When the people were asked, they said that they "had" to act as they did, even though they knew it would re-create the unwanted pattern. The researchers became curious and asked, "Of all the thousands of ways in which they could interact with each other, why did this particular pattern recur and persist despite their attempts to change it?" (Pearce, 2006, p. 9).

A pivotal discovery in $\mathrm{CMM}$ is that when a particular pattern of communication is established, it has the tendency to attract episodes that are similar - and thus sustain and 
strengthen the initial pattern. People do tend to 'play the game' and make use of the linguistics that fit with the communication form/pattern created. Certain positions are created within the communication, making possible some options for action, while making others impossible or more unlikely. So even though CMM emphasizes the importance of choice when changing destructive patterns, it also acknowledges the difficulties in doing so and the strong constituent powers of communication.

Pearce (2006) states that we know that cooperation is more productive and pleasant than conflict, and raises the question of how we can act in such a way as to make cooperation more likely. Dialogue is a particular desirable form of communication, so we need to learn more about what the ways of coordinating action are that call cooperation into being (p. 9). Finally, Pearce suggests that theories within the communication perspective have common purposes, such as these:

> "To understand what is happening (at a level deeper, richer, broader than one could without using the disciplining and enabling tools of research).

$>$ To experience the transformative learning that occurs, when we understand the world around us more deeply, richly and broadly.

> To create preconditions of constructive relationships with others with whom such relationships seem unlikely without doing some unusual interpretive and integrative work.

$>$ To stand in front of peers, clients, communities to make warranted assertions about what is going on.

$>$ To develop constructive critiques of practices and patterns of social interaction enabling reflection, evaluation, and deliberation about choices among options.

$>$ To develop practical wisdom enabling us to identify and to act wisely in crucial moments".

(2006, p. 7)

Since these purposes match perfectly with my hopes for this study, I cannot ignore the use of CMM as an analytical and conceptual toolbox. As explained in the introduction, I first wish to understand what is happening in interactions between schools and families that function or work as exclusionary drivers, forces or processes. Secondly, I hope to understand and learn in ways that can be transformative - both of myself as a researcher, a consultant and a parent - but as importantly of society, of school professionals and of teacher training institutions and educators. This is the main purpose of my research: to be 
able to foster new ways of communicating and relating in school-family collaboration for the good of the students. Thirdly, I hope this research is a showcase of how to create preconditions of constructive relationships in situations with conflict and adversarial positions. Fourthly, I imagine standing in front of peers to make warranted assertions about exclusionary processes in schools, both defending this dissertation and in other cases as a professional, a researcher and author. Fifthly, I urgently wish to develop a constructive critique of the exclusionary practices and patterns of social interaction, that in most cases have been left unnoticed. I wish this critique to enable reflection and deliberation about possibilities of choices among more options. Finally, I aim towards developing practical wisdom that enables school professionals, educators, policy makers and the like to make skilled distinctions between good and not so good actions in crucial moments.

All research is purposeful and doing research from a CMM perspective aims to help people find better ways to act in communication and to change destructive and unpleasant situations and relationships into constructive, more pleasant and generative ones. It is about "how to set a context of the good" for others. I shall return to the purposes of CMM research in the following section. First I wish to highlight what Pearce refers to as three core principles in CMM that constitute the philosophical foundation (Pearce, 2003, p. 3), when focusing on communication as purposive and ongoing acting:

1. Persons as well as families, organizations and nations are deeply textured clusters of "persons-in-conversation". This idea is closely related to ideas of systemic (in the European context) and social constructionist thinking. As textured clusters, people are interconnected in various ways in a network of communication and relationships. What is done in one particular context or relationship changes or influences what happens in another.

2. Every form of communication has invariably some associated consequences, and communication is therefore always an opportunity to make something. What is said and done has an impact on the participants' understandings and relationships. What is made in the process is related to what kind of communication form that is performed. Is it confrontational, individualistic and attacking? Or is it appreciative, supportive and focusing on future solutions? Pearce emphasizes that even though what is made might be far from what the participants intended to make, yet that is what they made (p. 7). By this he points to the powers of communication patterns and that they have the potential to catch and retain people in undesired patterns of relating such as in adversarial positions ( $p$. 7). These are referred to as robust patterns (p. 9). 
3. The world is made, not found. This principle is built on social constructionist ideas of multiverse, multiple ways of understanding and multiple ways of being. This tenet of the communication perspective "consists of treating such things as beliefs, personalities, attitudes, power relations, and social and economic structures as made, not found ... in reciprocated communicative action" $(2006$, p. 7). When people notice what they are making together, they can choose to make something different. Therefore CMM holds deliberating, empowering and creating potentials.

The relational perspective is also found in positioning theory, which concentrates attention on the discursive positions people occupy as they take up the task of constructing communication. The next section will turn to this theory.

\section{Positioning theory}

Moghaddam and Harré (2010) state that positioning theory (similarly to CMM) is an approach to understanding "how people use words (and discourse of all types) to locate themselves and others" (p. 2). Winslade and Monk (2008) argue that there is some surface similarity to the concept of "role", however the differences between role and positioning are important, as positioning is more flexible and dynamic, and points toward the need to get away from thinking of people as occupying pre-ordained, fixed roles that come with a pre-written script. Moghaddam and Harré (2010) claim that positioning has direct moral implications, such as some person or group being located as 'trusted' or 'distrusted', 'with us' or 'against us', 'to be saved' or 'to be wiped out' (p. 2). Furthermore, "It is with words that we ascribe rights and claim them for ourselves and place duties on others" (p. 3). Harré (2012) has defined a position as:

... based on the principle that not everyone involved in a social episode has equal access to rights and duties to perform particular kinds of meaningful actions at that moment and with those people. In many interesting cases, the rights and duties determine who can use a certain discourse mode ... A cluster of short-term disputable rights, obligations and duties is called a position.

Davies and Harré (1990) suggest "positioning" as a term to refer to the joint process of negotiated self-narratives, but as Burr (1995) argued, the concept of positioning is also 
used by social constructionist writers to refer to the process by which our identities and ourselves as persons come to be produced by socially and culturally available discourses. According to Burr, the two ways of talking about positioning imply - not so much a difference of opinion - but a difference of emphasis, and operate similarly. It is just a matter of whether one is currently focusing upon the broad societal aspects of discourse or its manifestation in interactions between specific individuals. Winslade and Monk (2008) argue that positioning theory is in fact both (pp. 21-23). Burr (1995) explains that the concept of positioning offers a way of understanding the process by which a construction of a person is achieved. Every discourse has implicit within it a number of "subject positions" (such as "young/old", "feminine/masculine", "gay/straight", "culprit/victim"), and these obviously have implications for the person who is located within them. One's actions in the world as well as one's claim to "voice" depend upon how one is positioned within prevailing discourses. The positions available within discourses bring with them what Davies and Harré (1990) refer to as a "structure of rights". They provide the possibilities for, and the limitations on, what we may do or claim for ourselves within a particular discourse. Discourses address us as particular kinds of persons (a culprit, a student, somebody who comes from a problem family) and furthermore these "subject positions" cannot be avoided. Our choice is only to accept them or to try to resist them, and if we do not resist a particular subject position we are then locked into the system of rights (including speaking rights) and obligations that are carried with that position (p. 142).

However with their concept of position calls, Winslade and Monk (2008) enable us to distinguish between positions offered and positions accepted. A position call is an invitation to assume an identity within a relation, for instance, when a teacher meets a student's suggestion with the following response, "Look, I'm just trying to be reasonable here" (p. 45). Responding like this, the teacher positions the student as irrational, whereas the teacher himself is constructed as rational. In this sense, the teacher makes use of a culturally privileged discourse, the discourse of rationality, to create social positions of relative power and disadvantage; the rational teacher as privileged, the irrational student as disadvantaged.

A position call can be so powerful, that even though it potentially could be refused, it is actually inescapable in the moment. At a later point, it may be possible to re-position oneself and create another and more preferred position in the relationship but it is difficult to do so in the moment. People act on and are acted upon by social and cultural contexts of a society and culture in which interaction occurs. Thus, people both actively position 
themselves in relation to and are positioned by narrating social beings (Davies \& Harré, 1990; Harré \& Moghaddam, 2003). As we shall see in chapter 4 the parents are endeavoring to position themselves in opposition to the positioning of them enacted by others, while sharing their stories with me for the purpose of research. Engaging in research is thus itself a way of repositioning and self-(re)construction.

Analyzing interactions with the use of positioning theory makes it possible to go into detail of how particular positions, such as at-risk positions, are produced in communication and how they connect with specific discourses as ways of thinking that entail risk for student becoming. However, it requires that those experiencing the exclusionary positioning are given the opportunity to speak, and that there are people listening to what they have to say.

\section{Voiced research}

This study is located within the voiced research tradition which, according to Smyth and Hattam (2004), grew out of an interest in finding ways to include perspectives previously excluded, muted or silenced by dominant structures and discourses (p. 24). Voiced research takes as a starting position that (also/even/especially) quite lowly perspectives situated at some distance from the centers of power do have interesting things to say (p. 24). Shacklock \& Smyth (1997) argued that in telling stories of life, previously unheard, or silenced, voices open up to possibilities for new, even radically different, narrations of life experiences (p. 4). Fine and Rosenberg (1983) claim that, "Critical perspectives on social institutions are often best obtained from exiles, that is, persons who leave those institutions. This is perhaps why exiles' views are frequently disparaged as deviant and in some cases conspicuously silenced" (p. 257).

Smyth and Hattam (2004) as well as Sibley (1995) and Roman (1996) argue that the most neglected, but very important, perspectives to enable better understandings of the problem are those of the involved students and parents themselves. As Sibley (1996) puts it: "Explanations of exclusion require an account of barriers, prohibitions and constraints on activities from the point of the excluded" (p.x). It is time to take students' and parents' voices more seriously and invite them into research projects - as argued by Smyth and Hattam (2004) - but also into practical school development projects and indeed everyday problem-solving in schools. The very central question to ask when addressing exclusion in schools is how the problem might be seen from a family perspective. A change of perspectives here can give insight into how it feels for students and families to be caught up 
in the middle of interactive troubles in schools and appointed as the problem. With such knowledge it is possible to learn more about how to avoid exclusion and instead create inclusion.

McIntyre (1981) argues that humans are naturally storytellers and McAdam (2006) states that most people - when given a chance - have stories to tell. When they are refused the opportunity to talk, important perspectives, knowledge and insights are left out of the conversation. Bruner (1990) explains that story telling can be seen as both a way of telling about our lives and a method of knowing. Sparkes and Brett (2008) claim that stories are "a socio-culturally shared resource that gives substance, artfulness and texture to people's lives" (p. 295). That is to say, that we live in story-shaped worlds. In significant ways, stories constitute human realities and modes of being, as they help guide actions. Stories form the basis for and pave the way for who we are and what we might or might not do, as well of who we might become.

Educational researchers have argued that in most practices, including research, some voices are made silent, while others are privileged and set center stage (Fine, 1994; Roman, 1996; Smyth \& Hattam, 2014). Traditionally, they argue, the voices of students and parents have not been included in research and educational practices. Thus, these voices have been silenced. Foucault (1972) argues, that when people are not permitted to speak, oppression and subjugation are dominating. Winslade and Williams (2012) argue that to raise one's voice is an act and a performance of agency and power that may demand great courage. Pearce (2006) states, that voiced research is concerned with asking what voices are silenced and in what ways, for example by ignoring, rejection or condemnation. McNamee and Gergen (1999), talking about silenced voices, explain that it is interesting to see what voices are allowed to speak, and how these dominate the conversation (p. 13).

In chapter 5 , we shall listen to the stories of parents, that when finally offered a place to share their stories, come "forward as subjugated knowers" (Foucault, 2003, p. 7). What we shall come to learn is that the storytelling parents, although marginalized and silenced in relation to the schools, come forward as knowledgeable, valuable, responsible, worried, and as people who have something important to tell, when given a chance to speak. Participating in research gave the parents to opportunity to speak up for themselves, to perform agency, to resist the oppression, and to ultimately enlighten what had been hidden in the dark.

The first story, already presented in chapter 1 , gave an example of this. The mother told us she "couldn't help herself from crying", but also that it was profoundly humiliating to 
her. This can be seen as a response to the deficit positioning of her son and herself, and to the fact that she did not understand what was going on and how or why the school professionals could be so utterly wrong and unjust. It may also be seen as a protest, a sign of resistance, a sign of the face loss and a response to the loss of agency in the moment. When not understanding what was going on, but definitely feeling oppressed and blamed, it was difficult to act wisely, competently and powerfully. Lang has been quoted ${ }^{9}$ to have said that, "When the context is unclear, we invite craziness into the room". Having had the belief that the meeting was set up for her son to tell his story of being bullied in school, but being met with rejection and ignoring and a very different contextualization of the interaction, namely around her son as the problem, the context became unclear, and craziness was invited into the room. She found no way of acting with power or influence. This was one way that silencing took place, ultimately leading to exclusion. All of the stories to be presented in chapter five are examples of silencing and exclusion. Together they show how students and parents in various ways are positioned in negative unworthy deficit positions, where they have no say, no power, no voice, no influence, no agency. But, what we shall come to see, all of this could be different, and therefore in chapter 6 I shall be pointing out ways of creating inclusionary processes.

\section{Listening as responsive pedagogy}

The experience of not being listened to is a continuous issue in all of the stories to be presented in chapter 5. Bakhtin (1986) argues that, "For the word (and, consequently, for the human being) there is nothing more terrible than a lack of response" (p. 127). Fullan (2012) states, that responsiveness to parents is a pivotal element in keeping schools progressing in terms of students' social and personal development and learning outcomes. Responsiveness is both about respectfully listening and acting on what has been listened to in accordance with the moral purpose of schooling.

Davies (2014) explains the act of listening as, “... opening myself up to his (a student) idea, his pleasure. His happiness spills over and becomes my happiness too, so that I experience that crossing over where "becoming and multiplicity are the same thing" (p. 15). Davies is inspired by Deleuze and Guattari (1987) where difference is far from being a problem, but an asset in opening us up to what we could each become in relation to the

\footnotetext{
${ }^{9}$ The quote stems from a speech Peter Lang gave in Denmark, which has lived on ever since.
} 
other (p. 15). Davies states that in drawing attention to these micro-moments of being, she is working against the taken-for-granted ways of seeing (or not seeing) what it is that children do. Through listening to children, Davies wants to make visible within the creative, the intra-active encounters children engage in as they do the ongoing work of bringing themselves and their community into being. Davies (2014) continues explaining that she as a teacher - is not separate from her observations. Even when she is standing on the borders and observing children playing, the affective flow of what she sees engages her materially, conceptually and ethically. She is not a pre-existing entity who sees something that exists independent of her gaze, but inextricably part of it all, constantly becoming, just as the children are intra-actively becoming within the emergent community she and they are collectively producing. To Davies, children open up for teachers the possibility of listening without knowing ... and of entering into a relational heterogeneous community-inthe-making (p. 20); Children taught her to be aware of affect and of the movement inbetween one and another where each is open to being affected by the other. To Davies (2014) listening opens up moments of haecceity or grace, so that one is no longer the person one had been before:

To enter into joyful compositions with children we encounter, is to "combine to form a more powerful whole" (Deleuze, 1988, p. 19), a whole that enables us to compose ourselves anew, such that each experiences an increase in joy, as well as, crucially, an increase in the power to think and to act. Such encounters open each particular being to the intensity of their own experience in relation to other (p. 20).

Winslade and Williams (2012) draw on inspiration from White when stressing the concept of double listening. They state that as we engage in double listening, we hear greater complexity in what people say, sometimes even within the same sentence. Double listening hears both the problem story and the story of hope (p. 20). Through double listening it is possible to go behind or beyond totalizing descriptions, even one's own, to make room for alternative stories and futures.

Following on these lines, Davies (2014) argues that different kinds of listening lead to different kinds of communities and ways of being. She argues that usually we listen in order to fit what we hear into what we already know, but that this is not to be listening at all. Listening is an emergent act and not a simple extension of usual practices of listening. To some extent it involves working against oneself, and against those habitual practices 
through which one establishes, "This is who I am". She states that emergent listening presents a major challenge to liberal humanist and phenomenological constructs of self as it means to be human, where those constructs begin with the concepts of self as an entity that is continually judges against an imagined ideal, and is found wanting (Davies, 2010).

Referring to Rinaldi (2006) Davies states, that emergent listening requires a suspension of our judgments and above all our prejudices but, more than this, it means opening up the ongoing possibility of coming to see life, and one's relations to it, in new and surprising ways. By emergent listening what was invisible before becomes visible (Davies, 2014 , p. 24). It opens up to the possibility of new ways of knowing and new ways of being, both for those who listen and those who are being listened to. Rinaldi (2006) says that learning how to listen is a difficult undertaking (p. 114), but as Bergson (1998) states when it is mastered, it creates predisposition toward change that is a vital element of creative evolution. Davies (2014) states that emergent listening is always in tension with the tendency to make things solid to classify them, to territorialize them. She argues that we continually attempt to fix the unfixable in place and that we incorporate the new and unexpected movement into the already known, we regulate it in the hope of holding and repeating it:

The desire to regulate and control, exacerbated these days by neoliberal governments (Davies \& Bansel, 2007b), creates an ever-present danger of turning emergent listening, and the related strategies of attention, into listening-as-usual, that is, into, repetitive listening, not requiring any thought, and serving to reiterate that which is already known (p. 25).

McNamee and Hosking (2012) argue that listening gives space to the possibility of becoming other (transformation) and for this reason, listening is given a central place in many approaches that explicitly focus on dialogue. As they add, in this very special sense, listening needs a lot of practice, where one difficult issue is learning how to let go of one's own stories as a reference point (p. 76).

The technologies of listening can produce a form of closure or foreclosure, but listening can also be transgressive, emergent, opening up possibilities for becoming in relation, becoming different and becoming somebody together. The question is what kind of listening is offered when schools respond to interactive troubles, and how the kind of 
listening chosen influences, affects, shapes and forms the following events and unfolding relationships.

\section{Speaking with relational responsibility}

Emergent or double listening opens up possibilities that usual practices of listening foreclose. When being able to listen, being open to new ways of knowing and new ways of being in relation, fixed lines of events can be transgressed or prevented in order to pave the way for better social worlds. What this requires - besides the attentive double listening-can be called speaking with relational responsibility.

McNamee and Hosking (2012) argue that in relational responsibility the responsibility is for the process and the kinds of people and worlds it (re)produces; to be relationally responsible (ethical) is to be attentive to the very process of relating itself (p. 106). To McNamee and Hosking a potential (ethical and practical) interest becomes one of opening up (rather than closing down) possibilities and an orientation to change from "within" (transformation) rather than from "the outside". Edwards and Potter (1992) argue that relational processes are "reality-constituting practices" (p. 27). Thus what is said, for example, at a parent-school meeting constitutes the reality for those involved.

Referring to Bakhtin (1981) and Wood (2004) McNamee and Hosking argue that it is not enough to say that response is central to dialogue. Responsiveness, to be precise, arises out of and is made possible by qualities of thought and talk that allow transformation in how one understands the self, others, and the world they inhabit (p. 41). As argued throughout this study there are ways of responding (to interactive troubles) that are not fruitful to the becoming somebody of the student, but, in fact, marginalize and stigmatize students and families. Sampson (1993) describes the Western individualistic construction of the person as monological and thus refers to the self-serving l-it forms of relations generated within the modernist discourse. I-it forms of relations or subject-object relations are asymmetric; the observer (I/school professional) observes and classifies the student (it) in specific discursive categories. In contrast a dialogical view offers a very different understanding of humans and interaction. "The most important thing about people is not what is contained within them, but what transpires between them" (Sampson, 1993, p. 20). And he goes on, the "emphasis (is) on the idea that people's lives are characterized by the ongoing conversations and dialogues they carry out in the course of their everyday activities" (p. 20). The I-it relationship is transformed into we-togetherness; the domain of ethical action and 
attentiveness to what "we"-are-doing-together-in-this-context-now (McNamee and Hosking, 2012).

For McNamee and Hosking interrelatedness and dialogical views are ways of speaking about letting go of subject-object constructions and opening up to relationally-engaged practices that invite and allow "the outside" in, so to speak (p. 102). As they argue, dialogical practices include surrendering, suspending our usual constructions of what is "real and good", appreciating rather than evaluating, and opening up to ongoing-ness ... dialogue can provide the space in which "new realities and practices are fashioned" (Gergen, 1994, pp. 62-3).

Speaking with relational responsibility is important because speaking produces positions that can be totalizing, stigmatizing and exclusionary, if not carefully considered. Speaking from within the deficit-discourse focuses on problems, individuals and deficits, which open up the risk that the ones that are spoken about are marginalized.

\section{Marginalization, dropping out and youth at-risk}

In chapter two I dealt with reproduction theory as an explanatory model for marginalization and argued that this theory succeeds in understanding how culture, gender, social class and status are structuring and to some extend determining or at least predispositioning the life course of (groups of) individuals. I also argued that we need to go beyond reproduction theory in order to discover things that get structured in the moment, such as the exclusionary processes of middle class families in schools that cannot be explained by culture, gender or social class. In this section I shall elaborate further on that argument.

Levitas, Pantazis, Fahmy, Gordon, Lloyd and Patsios (2007) state that in a large part of the research literature social marginalization is described as "multi-dimensional" where different social and psychological problems often play together. Thus social marginalization occurs and takes place in an interaction between both structural (such as economic crises or housing shortages), institutional (such as welfare system centers), interpersonal (such as poor social networks) and individual levels (such as mental illness or poor social skills). However they argue social marginalization is traditionally understood as something that arises from individuals' social and psychological problems in many different areas of life.

Benjaminsen et al. (2015) claim that the term "vulnerable groups" is used to describe citizens, who for one reason or another find themselves at the margins of society. 
Vulnerable groups (such as, for example, the homeless, drug abusers, or mentally disordered citizens) are talked about as being socially marginalized from the rest of society. Benjaminsen et al. (2015) write that psycho-socially vulnerable individuals are in the greatest risk of being hit by structural constraints as, for example, increasing unemployment. These researchers are thus in line with the logic of reproduction theory. It might as well be understood the other way around, saying that individuals who are affected by structural constraints such as unemployment, are at greatest risk of developing psychosocial vulnerabilities. Or at least one might suggest that these dynamics function both ways. In chapter one I addressed the phenomena that research often assumes a specific linearity, which can make us blind to things not filling in with this linearity.

Based on their studies, Benjaminsen et al. (2015) found that people who are socially marginalized as adults left school early and have been out of work for large parts of their lives. However, middle class young people who are faced with social marginalization attend school longer than the most vulnerable marginalized youth, but still leave school far too early. Benjaminsen et al. give no explanations for this. Could it be the case that middle class families more strongly resist and struggle against the exclusionary processes than less resourceful families, and therefore they endure a longer time in the struggle, before finally giving up and leaving the school (being excluded)?

Could it be the case that the "later" early school leaving that Benjaminsen et al. found is due to the stronger and longer endurance of the exclusionary processes by middle class families, than by the more marginalized and less resourceful families? If this is the case, there seems to be a very close connection between invisible social exclusionary processes in schools, social marginalization and early (negatively motivated) school leaving.

As Benjaminsen et al. (2015) state, there is a significant loss of resources and failure linked to social marginalization, both for the individual who experiences being socially marginalized, but also for society as a whole. Therefore, Benjaminsen et al. (2015) argue, it is important to gain more knowledge about the mechanisms involved in social marginalization and how the mechanisms can be counteracted, and for this they suggest looking at exclusionary processes in schools. I add that we need to go beyond structuralist reproduction theory, when studying these mechanisms.

Smyth and Hattam (2004) show that categorizing or stereotyping early school leavers involves the processes of homogenizing, naturalizing and rationalizing (p. 15). As they explain, homogenizing early school leavers involves considering them as a collective, and thus sight of important differences from case to case, is lost. Naturalizing early school 
leaving involves accepting it as just the way things are, which entails the same danger of losing important insights. However, as Smyth and Hattam argue, this view appears to be widespread as many believe that what happens in schools is somehow an inevitable playing out of nature (p. 16). However such a view is misleading, because early school leaving is not "just natural", but socially constructed and depends upon certain conditions. It is a product of the institutions, systems, and cultures, that are created and sustained through human interaction. The last stereotyping that Smyth and Hattam point to is rationalizing, which involves relying on what Fine (1994) calls "moral boundaries of deservedness that thread research and policy" (p. 74). Rationalizing entails the belief that we can distinguish "those who are deserving", while honorably neglecting "those who are undeserving". As Fine states, it is expressed like this: "We are doing our best under the circumstances - and those who leave early haven't tried hard enough." Rationalizing lets the system off the hook, and places the blame entirely on the student (p. 74).

Giroux (1991) argued that school processes leading to dropping out have not been researched much. Fine (1994) and Smyth and Hattam (2004) claim that research that has been interested in understanding dropping out, most often looked at cultural, societal and structural causes inspired by reproduction theory. Fine (1994) argues that in studying dropping out it is pivotal to erode the stereotypes or categories and to work against protecting privilege, securing distance, and laminating the contradictions (p. 72). Categorizing and labeling make differences. When it comes to dropouts, Smyth and Hattam (2004) argue that the language that has tended to saturate public and policy discussion has been around the notion of "youth at risk". They explain that:

What is created is a kind of "ideological diversion" that distracts our attention. The notion of "at risk" offers a deceptive image of an isolatable and identifiable group of students who, by virtue of some personal characteristic, are not likely to graduate from school

As Fine (1995) and Smyth and Hattam (2004) argue, both the way we talk about these things and the theories of understanding that we use may enhance the marginalization. Having this in mind, research needs to work "in between" categories or to ultimately avoid categorization and stereotyping of people in order to not substantiate someone's privilege over others, or to unwillingly confirm taken-for-granted assumptions about social marginalization and exclusion. To succeed in that, I need not simplifications, 
but a theory capable of handling complexity, when studying the complex situations around social exclusionary processes in schools.

Ejrnæs (2011) states that reproduction theory gives a partial picture and cannot explain everything. To sum up Benjaminsen et al. (2015) and Ejrnæs (2011), I wish to highlight that marginalization and social exclusion in schools cannot be simply explained by family background alone, and to add to them that we need to study not the family background of students, but the exclusionary processes themselves. In chapter 1 I proposed thinking of inclusion as a continuum, where students can feel more or less included. In this chapter I propose a similar understanding of exclusion, where stigmatizing processes ultimately leading to dropping out can be understood as a continuum, where students can be more or less stigmatized, more or less marginalized and more or less excluded.

\section{Exclusionary practices}

Sibley (1995) and Smyth and Hattam (2004) foreground the more opaque instances of exclusion. The distinction between processes of exclusion and exclusion as a result or outcome is worth noticing. Exclusion as an outcome happens when a student is expelled from the school, or when the student and family see no other alternatives than to leave the school. Then the family needs to find another school, or in the worst case scenario, the student fails to go to school at all for a shorter or longer period. Processes of exclusion are more lengthy and may entail stigmatization, marginalization, conflicts and the like, that sometimes leads towards exclusion as an outcome, but not always. Processes of exclusion can endure over years, they can be more or less powerful or dominating and they can dry out or be transformed into inclusionary processes.

Sibley (1995) argues that processes of exclusion in education are worth investigating, because they "are less noticed and so the ways in which control is exercised in society are concealed" (p. ix). Exclusionary processes in schools are often invisible, but it is not just a question about what is visible or invisible, but also to whom. Processes of exclusion are invisible to different people for various reasons. Firstly, because "what happens" seldom is related to ideas of exclusion but to various other things, such as misbehaving students, troublesome parents or unreasonable demands on school capacity. Not even the professionals directly involved in producing exclusionary processes might realize "what is going on". This leads to overlooking or neglecting the seriousness of the problem. Secondly, exclusionary processes take place "in the shadows" of public life, such as in 
school-family meetings, through emails and telephone calls and in teacher-student meetings or in classrooms. In the data to be presented in chapter 5 , we shall learn that when a family is experiencing being excluded, it is often so shameful that they do not wish to talk about it. Juelskjær (2009) shows in her PhD study that social exclusion in schools is related to great shame, humiliation, and distrust. It is rarely spoken of and barely shared among people in public. Being eager to "start afresh" in the new school, experiences with exclusion are left out of the conversation (Juelskjær, 2009). This contributes to the invisibility of the matter.

Studying exclusionary processes from a communication perspective makes visible various driving mechanisms. Foucault (1972) describes how discursive practices - such as positioning somebody as problematic - systematically shape and form the objects that they describe. According to Foucault discursive practices implies not only the spoken language, but also other forms of communication and ways of engaging and participating in such practices. Gilliam (2012) and Jørgensen (2016) found that schools offer and to some extent determine student identities such as "disadvantaged" and "another ethnicity than Danish". Lauritzen (2016) argues that categories may appear as absolute and complete, and are created through differentiation, where categories gain their meaning in relation to each other. Haslebo and Lund (2014) argue that positioning a student or a group of students as "problematic" is fairly usual and can be done in a series of ways. Hereby a differentiation between "problematic" and "not problematic" students (perhaps also called the normal, the nice, the sweet, the clever ones) is made. The two categories "problematic" and "not problematic" emerge in a pair and as each other's opposites through differentiation. As Haslebo and Lund (2014) show, this differentiation and positioning of some students as problematic may lead to a significant deprivation of their possibility of being perceived as worthy participants and contributors to the class community. For students who are positioned as problematic it becomes harder to perform interest and engagement in teaching and learning, both because the "role of being problematic" itself does not give many possibilities for it, and because others will be more likely to meet them with less expectation. Rosenthal (1977) shows that when meeting students with low expectations, their possibilities, performances and development are degraded. What Rosenthal (1977) discovered was that low expectations lead teachers to pay less positive attention, give less approval, ask more simple questions and jump to sanctions and scolding more quickly. Haslebo and Lund (2014) showed how these mechanisms functioned in Danish schools in 2014. Low expectations also lead to understanding student behavior according to the student position as "problematic" and to the interpretation of actions and utterances in 
negative ways. As Haslebo and Lund (2014) state, once a negative relationship between teacher and student is formed, the desire to communicate decreases for both parties and both are more focused on the negative sides of the other. This is referred to as selective attention or selective memory and explains how attention is directed towards the things that confirm the established position. The risk that students positioned like this experience themselves as less included in the school community becomes greater.

Gilliam (2012) and Haslebo \& Lund (2014) argue that struggling with "problematic students" can make the job of a teacher more difficult. If the teacher is about to give up hope of ever being able to improve the learning environment due to problematic students, it seems obvious to involve others, such as special education teachers, school psychologists, parents and principals. But as Haslebo and Lund (2014) argue, if the involvement of others is based on the storying of certain students as problematic, often a shared blaming is put on the individual student, which only increases further the risk of student marginalization. Dyssegaard et al. (2013) found that school professionals with no specific additional training risk stigmatizing students in problems (p. 84). Haslebo and Lund (2014) found that blaming and individualizing approaches to interactive troubles in schools made the vicious spiral continue to grow stronger and empowers the exclusionary processes by involving more and more people confirming the problem-, individual- and deficit thinking.

McGrath (2006) argues that punishments and sanctions can make problem behavior and interactive troubles like bullying worse. She states that a sanctioning approach to bullying behavior does not reduce the likelihood of bullying events or revenge, and thus not the bullying pattern. The needs of the victims and the school community are not being met by a sanctioning approach, and most often the bullying increases.

Following on these lines, Haslebo and Lund (2014) found that punishment and sanctioning in Danish Schools are very common. They state that punishment for rule violations in schools can consist in students being denied access to being physically present in the classroom. Punishment, thus becomes a systematic way in which students are deprived of their right to be present. They are excluded physically, which makes impossible the three other categories of inclusion to be explained later in this chapter. When a student is not present, the possibilities of belonging, participating and learning from the teaching are automatically impaired, and gaps in learning that are difficult to "fill out" later, have emerged. Punishment, such as being sent outside the door, or to go "sweat" in another class, being sent to the principal's office and the like affect not only the student being punished, but also the other students in the class who are caught in a loyalty dilemma. 
Should they stick with the teacher and support the punishment or be loyal to their classmate and support him? As Haslebo and Lund (2014) argue, students in classes where punishments are practiced can become more concerned with who is inside and who is outside the class community than with the content of the teaching and learning, or with the potential to eliminate the concentration on learning with poorer learning outcomes. Therefore, punishing a student by using exclusion impacts not only the student, but the whole class community and culture, as well as the teacher.

When it comes to who gets to be included and who does not, Smyth \& Hattam argue, there are "implicit rules for inclusion and exclusion". Both metaphorically, as well as actually speaking, they say, these implicit rules determine who is welcome and who gets ejected. And they continue; "The institution of schooling is such that expectations abound as to what constitutes comportment, and there are clear and well articulated views about what is "deviant", "out of place" or likely to threaten the "image" of places called school" (p. 10). Furthermore, they point out, it is when the boundaries are contested, when the barriers are experienced and confronted that we begin to get some clues about how power relations and social control are exercised.

Søndergaard (2009) argues that thinking technologies leave reflection tracks and practical tracks. She defines thinking technologies as ways of understanding what is going on, and explains that it is pivotal to the quality of interaction and wellbeing what kinds of thinking technologies are used. Studying bullying and the production of contempt amongst students, she found it pivotal to the outcome if school professionals made use of a blamefocused thinking technology, seeking to identify the guilty aggressor and the innocent victim, or if school professionals used thinking technologies focusing on social processes and the dynamics amongst children that invite specific children to participate in the production of contempt towards other children. She states that the curiosity of the school professionals are better directed towards questioning how come it becomes legitimate for children to produce contempt and what would make it legitimate to produce kindness and friendship, instead of asking what is wrong with an individual child.

Hansen $(2005 ; 2009)$ explains bullying as a strong form for community that creates a "we" by excluding others, the "them". She argues that victims of bullying are threatened in their zest for life and their entire livelihood. She found that children as well as adults can suffer from posttraumatic stress syndrome from being bullied. Bullying is the result of a community that has developed into a marginalization community driven by created insider- 
and outsider-patterns. It is the patterns that are vicious, not individuals, and it is the patterns that we need to interrupt and change.

Thomas and Loxley (2001) point out that inclusion and exclusion are affected by the way we talk about problems. The tendency to categorize individual students as problematic, disruptive or with low self-esteem automatically refers the problem to students, which prohibits the school discovering socio-cultural explanatory models (pp. 56-57). At the same time, they point out that it is naïve to think it is possible to change the structures of the schools by goodwill alone (p. 3). They state that, "Inclusion cannot, in other words, be effected simply on the basis of the way that teachers and academics conceptualize difference; it is part of a complex wider picture" (Thomas \& Loxley, 2001, p. 88). What they argue is that schools are not inclusionary just because people agree that it is a good idea, but that it is created by active efforts to change traditions and practices in schools, such as not to blame individuals or to search for explanations within individuals. They argue for a school system that welcomes diversity in ways that are responsive to differences and challenges the understandings of normality. The point they make is that people that are in between categories or outside categories can tell us important things about the humanity of systems that we created to organize our lives and societies (p. 84). Skidmore (2004) argues that the challenge is to listen to them and their perspectives and if we do not, we risk developing into a more segregated society instead of an inclusionary and diverse one; "schools for all ... are schools which are created by, rather than for, all pupils" (p. 34).

Søndergaard (2009) explains the concept of social-exclusion-anxiety that builds on a social psychological understanding of humans as existentially dependent on social embedding. If a child experiences being in danger of being excluded from the group, $s($ he) experiences anxiety, and thus produces emotions and behavior aimed at minimizing the anxiety. As $\$ \emptyset n d e r g a a r d$ argues, in some cases this anxiety-minimizing-behavior can produce contempt towards others in the attempt to minimize the significance of others to a level of control. If it is responded to with aggression and blame from school professionals, the vicious and exclusionary spiral swirls.

\section{Social Exclusion}

According to Levitas et al. (2007) there is a range of existing definitions of social exclusion. SEU (1997) defines it as a shorthand term for what can happen when people or areas suffer from a combination of linked problems such as unemployment, poor skills, low 
incomes, poor housing, high crime environments, bad health and family breakdown. DSS (1999) says that social exclusion occurs where different factors combine to trap individuals and areas in a spiral of disadvantage (p. 23). Hine and Mitchell (2001) state that social exclusion is a process, which causes individuals or groups, who are geographically resident in a society, not to participate in the normal activities of citizens in that society. Howarth, Kenway, Palmer and Street (1998) states, that the notion of poverty is where people lack many of the opportunities that are available to the average citizen. This broad concept of poverty coincides with the emerging concept of social exclusion. Barry (1998) states, that social exclusion is processes by which individuals and their communities become polarised, socially differentiated and unequal. Walker and Walker (1997) argue that social exclusion is the dynamic process of being shut out from any of the social, economic, political and cultural systems which determine the social integration of a person in society. Gordon, Adelman, Ashworth, Bradshaw, Levitas, Middleton, Pantazis, Patsios, Payne, Townsend and Williams (2000) claim that social exclusion is the lack or denial of access to the kinds of social relations, social customs and activities in which the great majority of people (in British) society engage. In current usage, social exclusion is often regarded as a 'process' rather than a 'state' and this helps in being constructively precise in deciding its relationship to poverty (p. 73). Burchardt, Grand and Piachaud (2002) argue that an individual is socially excluded if $(a)$ he or she is geographically resident in a society but (b) for reasons beyond his or her control, he or she cannot participate in the normal activities of citizens in that society, and (c) he or she would like to so participate (pp 30,32). Room (1995) defines social exclusion as inadequate social participation, lack of social integration and lack of power. Duffy (1995) states that social exclusion is a broader concept than poverty, encompassing not only low material means but the inability to participate effectively in economic, social, political and cultural life and in some characterizations alienation and distance from mainstream society. According to the EU Employment and Social Affairs Directorate social inclusion is the development of capacity and opportunity to play a full role, not only in economic terms, but also in social, psychological and political terms. Estivill (2003) argues that social exclusion is an accumulation of confluent processes with successive ruptures arising from the heart of the economy, politics and society, which gradually distances and places persons, groups, communities and territories in a position of inferiority in relation to centres of power, resources and prevailing values (p. 19).

According to Klasen (2001) Room (1995) adds a new dimension to the discussion by couching the issue of social exclusion in a rights-based language when he talks about social 
exclusion as the denial or nonrealisation of civil, political, and social rights of citizenship. Such a rights-based approach to the problem of social exclusion has much to recommend it, according to Klasen. It has great affinity with the capability approach developed by Sen which calls for efforts to ensure that people have equal access to basic capabilities such as the ability to be healthy, well-fed, housed, integrated into the community, participate in community and public life, and enjoy social bases of self-respect (Sen, 1999). The term social exclusion would then be seen as the denial of the latter three important capabilities. For this study, it seems that the part concerning self-respect is particularly important.

Following Klasen (2001) who states that, "One can see social exclusion among nondisabled groups as socially generated barriers that reduce the ability of the excluded individuals to interact with society" (p. 2), I emphasize that in this study, social exclusion produced in schools is a process that reduces the ability to interact, but it also stigmatizes and silences students and families.

Thus I refer to the exclusion taking place within a social system, such as a school, a class community or a group of people connected through a social setting. And, it refers to the exclusion of individuals that are legitimately entitled to be part of the community, but for various reasons either are excluded, or feel marginalized or unwanted to an extent where they themselves choose to leave. From the UN DESA draft from 2009 social exclusion is understood:

... as the condition (barriers and process) that impede social inclusion. Social exclusion is a process through which individuals or groups are wholly or partially excluded from fully participating in all aspects of life of the society, in which they live, on the grounds of their social identities, such as age, gender, race, ethnicity, culture or language, and/or physical, economic, social disadvantages. Social exclusion may mean the lack of voice, lack of recognition, or lack of capacity for active participation. It may also mean exclusion from decent work, assets, land, opportunities, access to social services and/or political representation.

(DESA, 2009, p. 3)

The DESA definition is pivotal for this study, because it points out that social exclusion is a process through which individuals are wholly or partially excluded from fully participating in aspects of school society. Social exclusion may mean the lack of voice, lack of recognition, or lack of opportunity for active participation. 
As elaborated in chapter two, educational researchers such as Benjaminsen et al. (2015), Dannesboe et al. (2012), Dyssegaard et al. (2013) have stated that social exclusion in schools have potentially serious societal consequences. Klasen (2001) concludes based on his studies, that an educational system fails a portion of its students by not only denying them this basic right of citizenship, but also through fostering social exclusion as adults ( $p$. 18).

However unintentionally, this study reveals that exclusionary processes happen in Danish schools and with great negative impact on students' and families' lives (as we shall see in chapter 5), and with potentially negative impact on society as a whole. Having identified the concept of social exclusion, let us move on to the concept of inclusion.

\section{Inclusion}

Molbæk (2015) claims that inclusionary education can be seen from at least four perspectives. The first is an organizational one, where central questions focus on organizational culture and more specifically on collegial sparring and supervision as part of the school culture. The second perspective is a subject/content/didactic one and it asks about the ways in which teaching and student organizing are differentiated and done. The third is a relational perspective asking how communication about students and with students is conducted. The fourth one is a technical/skill perspective that asks what rules and routines dominate in the school, in the teaching team and for the individual teacher.

Tetler (2015) argues that it is important to go behind mechanism of exclusion and to keep asking questions about who is benefitting from it and who is losing. Madsen (2005) criticizes the folkeskolen (elementary school) for having a "diagnostic culture, where judgments of normality and categorizations are made, contradictory to the official education- and social political policies" (p. 34, my translation). Madsen (2005) points out the problem of a narrowed understanding of normality in schools: "Even though special educational settings first and foremost are about supporting students' professional learning outcomes, most of the referrals to special education are justified by social and behavioral problems" (p. 34).

Skrtic (1995) claims that:

What is so troubling today is that the inclusion debate is largely following the same pattern as the mainstreaming debate. It too is a form of naïve pragmatism that 
criticizes current special education models, and tools without explicitly criticizing the theories and assumptions that stand behind them.

Following Oliver (1992) and Skrtic (1995), Tetler (2015b) argues that developing inclusive education is not just a matter of willingness and desire, but also concerns questions of how. She states that research is obliged to make sure not be characterized by naive pragmatism in criticizing pedagogical practices, but to indeed conduct a systematic analysis of the underlying basic assumptions.

Thus Tetler (2015b) argues for the double role of research which is both to enhance the possibilities for participation and to remove exclusionary barriers $(p, 24)$. As she states, this seems even more necessary today after at least thirty years of inclusion efforts and still not having come much closer to understanding how inclusionary education can be achieved (p. 24). Allan (2010) claims that a reason for this is the large production of "technical help in the form of easy guides to inclusive education, because these types of quick and easy solutions fail to profoundly challenge pivotal aspects of inclusion such as equity and justice" (p. 610).

Graham and Slee (2007) claim that it is generally accepted that the notion of inclusion derived or evolved from the practices of mainstreaming or integrating students with disabilities into regular schools. As they argue, halting the practice of segregating children with disabilities was a progressive social movement and the value of this achievement is not in dispute. However, the charter is to always look for how we can improve things; to avoid stasis and complacency we must continue to ask, how can we do it better? (p. abstract). Pointing to the Foucauldian characterization of an 'ethic of discomfort' and following the principal of Nietzsche where one acts 'counter to our time and thereby on our time ... for the benefit of a time to come', Graham and Slee (2007) argue that this can be done by asking ourselves uncomfortable questions and develop a critical perspective. Thus, Graham and Slee begin with a fundamental question for those participating in inclusive education research and scholarship-when we talk of including, into what do we seek to include?

Tetler (2008) describes how schools are exposed to a double pressure that springs from the conflict between the perspective of equity offering equal opportunities for education and thus points to standardizing goals and curriculum, and the perspective of rights focusing on student diversity and thus points towards differentiated goals and 
teaching. Tetler describes four discourses that respectively can merge and mix in practice: the ideal world opposed to the real world, and the individual opposed to the community. These four discourses position themselves in relation to ethical, political, economic and pragmatic discourses (p. $40 \mathrm{ff}$.). Schools are constantly facing the dilemma of meeting the needs of the individual and meeting the needs of the community. Tetler characterizes this as the basic conflict of schooling (p. 43). As she claims, inclusion requires questions about the dialectical relationship between 'individual and community' and how a reciprocal learning relationship based on respect and equality can be developed and sustained.

Hedegaard Hansen (2011) offers a multi-dimensional understanding of the concept of inclusion, which entails the political discourse, the ideological discourse, the research discourse and the pedagogical discourse. The primary focus within the political discourse is that inclusion can gain a practical economic reduction in education expenses by including more students in general education and thus remove the need for special education. The ideological discourse springs from the Salamanca declaration emphasizing the individual's rights to education, personal development and participation. Within the discourse of research, Hedegaard Hansen (2011) points to various definitions of the concept, disseminating between full inclusion which is related to the ideological discourse, and responsible inclusion, that emphasize inclusion as a vision, that in practice is not reachable (p. 250). In relation to the pedagogical discourse multiple understandings are available, all with a more or less strong tendency of being normatively constructed. Here school professionals perceive inclusion as a threat to the individual child's development and learning, the other children's development and learning, the cohesion of the learning community and the professional's opportunities to teach ( $p$. 251).

Thus the concept is understood in various ways and the understandings are converging, different and antagonistic.

UNESCO (1994) states that inclusion in schools is about avoiding discrimination, embracing diversity and creating safe and prosperous communities. Inclusion is not integration of students with special needs, and it is not an intervention, but a basic belief, vision, and worldview based on the fundamental right for everyone to be counted as equal and important contributors. According to the Salamanca declaration (1994) inclusion is about the values of society, the perception of humanity and the appreciation of individuals being equal contributors to society. 
However, Oliver (1992) argues, that inclusion/exclusion is not alone a question about values and willingness. The exclusion problem - that is barriers to inclusion- are woven into the institutionalizing practices of society. The way to succeed in breaking away from the exclusion and stigmatization of more and more children is to change what people do - not just how they think. He argues that we need research that can reveal the institutionalizing practices that produce the marginalization and the stigmatization in order to outline a range of opportunities for more inclusive educational processes.

According to Dyssegaard and Larsen (2013) inclusion is defined as;

... active participation with optimal outcome for all students in the learning community. This means that students are together with and participate actively in the same teaching environment and learning community as their classmates. Furthermore, students gain optimal outcomes and develop positive self-images based on their participation in the learning community.

Emphasizing the development of positive self-images due to active participation in learning communities set agency and togetherness in center stage as pivotal to inclusion. Another definition is offered by Alenkær (2008) that entails four characteristics or types of inclusion:

Inclusion is the dynamic and continuous process in which the school increases the opportunities for the presence, sense of community, active participation and high learning achievement for all students. In this process, special consideration is given to students who are at risk of marginalization, exclusion and low academic achievement

The definition is useful in order to question how various events and communication patterns in schools can affect inclusionary and exclusionary processes. First, inclusion is seen as a dynamic process where school professionals are responsible for offering opportunities for inclusion of all students. Secondly, the concept of inclusion is nuanced into four categories that connect with the physical, the mental, the social, the relational, and the professional.

1. Presence: Presence is about the functioning and organizing of the school in such ways 
that all students receive education at the school. Presence includes both physical and mental presence during teaching and other planned joint activities.

2. Sense of Community: This is seen from the perspectives of students, and inclusion is not only to be physically or mentally present. If the student feels neglected and ignored or not accepted as a member of the community, (s)he is not included.

3. Active Participation: Inclusion also means that the student will have the opportunity to actively participate in educational activities and will be relied on as a contributor to the common learning.

4. High learning outcomes: Physical and mental presence, sense of community and active participation could theoretically take place in student groups, that see themselves as separate from the teaching and school purposes. It is of course not desirable. Therefore, it is important to organize inclusionary processes that are closely related to specific learning objectives.

Thus, in this definition it is important to pay attention to small and larger everyday events and how they affect inclusion. This implies an ongoing process of learning and a curiosity to explore what actions promote inclusionary processes and what actions increase the risk of exclusionary processes. Haslebo and Lund (2014) offer a "translation" of the four categories of inclusion alongside their exclusionary opposites. Remembering that all four elements of inclusion are needed in order to be able to say that inclusion is accomplished, the table below illustrates that inclusion quickly can become exclusion.

Table 3.1. Inclusion and exclusion

\begin{tabular}{|l|l|}
\hline $\begin{array}{l}\text { The four types of } \\
\text { Inclusion }\end{array}$ & The equivalent types of exclusion \\
\hline Presence & $\begin{array}{l}\text { Withdrawal of students right to be physically and mentally present, for } \\
\text { example such as being sent outside the door or to the principal's office }\end{array}$ \\
\hline Sense of community & $\begin{array}{l}\text { Marginalization of students in relation to the class communities, for } \\
\text { example by positioning the student as problematic }\end{array}$ \\
\hline Active participation & $\begin{array}{l}\text { Making students invisible, for example through the deprivation of their } \\
\text { right to be accepted as a participating contributor (not listening, ignoring, } \\
\text { ridiculing) }\end{array}$ \\
\hline High learning & $\begin{array}{l}\text { Poor learning outcomes from teaching, but possibly learning something } \\
\text { else. }\end{array}$ \\
\hline
\end{tabular}


Haslebo \& Lund (2014) argue that the traditional concept of inclusion springs from a deficit-, individual and problem-thinking, where the "not normal children" are to be included in the group of normal children. They claim that inclusion that fails amounts to exclusion, and both inclusion and exclusion is at play in every school, in every situation and in every conversation. Traditionally, the concept offers only very few positions, such as "the not normal" that are included, "the normal" that suffer from the included and "the rescuer", which is the competent teacher fixing the situation. But it may very well be the other way around; the child that is not successfully included is a victim of exclusion, the teacher that does not succeed in including all students is either a victim of the impossible task or a culprit that excludes students. The teacher that succeeds in inclusion is a hero. As Haslebo and Lund (2014) claim, neither of these positionings are especially helpful in order to create an inclusive learning community, because they lock those involved in fixed relationships. Therefore Haslebo and Lund (2014) suggest thinking differently about the concept of inclusion and offer an alternative understanding with more equal and positive positions. Instead of thinking in terms of inclusion, we might think in patterns of communication and how language offers certain positions and constitutes realities. Ways of speaking, categorization, labeling, and basic assumptions can include and exclude. Being attentive to the performative powers of language will focus on the way school professionals speak. Inclusion happens in language and actions, and thus all school professionals have the power to include or exclude.

From a relational constructionist perspective all stakeholders around a school are obliged to contribute to creating an inclusive learning community. As role models teachers and principals show how to perform an inclusionary communication and attitude in their ongoing everyday interactions. Through role modeling, students learn from teachers to perform inclusionary communication and actions. All stakeholders step in and out of smaller and bigger communities. Understanding inclusion as patterns of communication makes visible what teachers can do to create equal possibilities of participation for all students.

Slee (2003) raises the question of whether inclusion as an ultimate goal is possible at all, and states that at least it would require a school system, that continuously challenges all its exclusionary mechanisms and avoids judging any groups of students based on a narrow understanding of normality. Allan (2010) highlights the school system's current intrinsic contradiction (the simultaneous goal of increasing students' academic standards and 
promoting inclusive processes). She broadens the inclusion challenge to an issue of whether and how the school can educate the individual to function in a competition-dominated world, while ensuring that these individuals can work together and understand their civic responsibility. It creates many dilemmas when the ideal of inclusion meets practice. Inclusion is not just perceived as a struggle for individual rights, but as an effort to implement institutionalized communities democratic values into practice in the school.

Tetler (2009) warns about two contradictory definitions. If inclusion becomes a fight for individual rights (redistribution of resources) it involves the continued stigmatization of individuals and a confirmation that some are different and thus challenging the school's narrow understanding of normality. On the other hand, if inclusion becomes a question of changing the attitudes of school professionals there is a risk of making invisible that some children do have special needs that require special and differentiated educational offerings. According to Tetler (2009) there are no simple solutions to the dilemmas that arise when the ideal of inclusion is implemented in everyday practice, but it is the commitment of research to help to articulate the complex and difficult requirements associated with being inclusive. This will include research that is interdisciplinary in its approach.

Kirkegaard (2014) states that inclusion is about broadening the understanding of normality and creating options for participation for all students in inclusionary learning communities. It is not the structural inclusion (the number of students enrolled back into general education from special education), that pressures schools, but the need to rethink current practices and unintended exclusionary processes. Kirkegaard argues that in order to do that, school professionals must be very skilled in communicational and relational competencies, and they must develop new attitudes and options for action. Finally, it requires new ways of collaborating between parents and school and between school and support services, such as psychological support, social support and community support. Importantly, he argues, it is most urgent, and we as society cannot afford not to do this. We need to go beyond asking: are we for or against the ideal of inclusion, and instead start asking how we can succeed in being inclusionary.

School structures are important too, but inclusion is also created in language and actions and thus all school professionals need knowledge about the creative and constitutive powers of language, especially about positioning. Everyone can learn to use inclusionary language. In an inclusive school the professionals might continuously strive to include all students within all four forms. However, it is difficult to imagine a school where there are no exclusionary processes going on somewhere. All students cannot participate in 
a unified community at the same time. School professionals and students are present and actively participating in a variety of large and small communities. When they are included in one community they may be outside another. This makes it not so easy to distinguish between inclusionary and exclusionary processes. From a relational ethical standpoint it is an important point that it is not the aim or purpose of the teachers that is decisive, but the effects of their actions. If a student is excluded from class as a punishment for disruptive behavior or abusive language, there is a high risk that the student feels excluded - regardless of the teacher's intention. Inclusion and exclusion varies with the perspective from which it is perceived.

Tetler (2009) has argued that inclusionary interventions paradoxically can have an exclusionary effect. Such issues can be segregating and thus hinder students from acquiring the necessary competencies in order to participate in the learning community. Thomas and Loxley (2001) state that it is important what kind of participation students are offered in schools. The kind of participation offered will determine the kind of learning that is acquired. This will eventually shape and form the development of the student.

Dyssegaard and Larsen (2013) showed that there is not a negative effect on students' social development and learning outcome of including students with special needs in regular education. But as they highlight, it is highly important to the students with special needs, that the school has an overall policy and positive attitude towards inclusion. Teachers with a negative attitude to inclusion of students with special needs have a negative impact on those students learning outcomes and social development. Furthermore, the report states, negative attitudes amongst teachers can lead to stigmatization of students with special needs and thus social contagion. For students with special needs it is important that teachers are instructed to work collaboratively, which has a positive effect on all students. Where teachers work individually it has a negative effect. If school professionals are not very careful and trained, it is a risk that they stigmatize students. However, the study shows that it is possible to successfully include students with special needs and have a positive effect on all students, when teachers are trained, when resource professionals are offered, when direct support is given in the classroom, and when school professionals have knowledge about inclusive teaching methods and interventions targeting students with special needs.

Booth and Ainscow (2000) state that in order to develop inclusionary practices it is important that schools analyze their cultures, policies and practices and identify the barriers 
to learning and participation that may occur within each of these areas. They offer the following characteristics of inclusion in education:

- Valuing all students and staff equally.

- Increasing the participation of students in and reducing their exclusion from the cultures, curricula and communities of local schools.

- Restructuring the cultures, policies and practices in schools so that they respond to the diversity of students in the locality.

- Reducing barriers to learning and participation for all students, not only those with impairments or those who are categorized as 'having special educational needs'.

- Learning from attempts to overcome barriers to the access and participation of particular students to make changes for the benefit of students more widely.

- Viewing the difference between students as resources to support learning, rather than as problems to be overcome.

- Acknowledging the right of students to an education in their locality.

- Improving schools for staff as well as for students.

- Emphasizing the role of schools in building community and developing values, as well as in increasing achievement.

- Fostering mutually sustaining relationships between schools and communities.

- Recognizing that inclusion in education is one aspect of inclusion in society.

According to Booth and Ainscow (2000) developing inclusive education is a matter of working with school cultures, policies and practices.

Clausen and Sørensen (2013) argue that inclusion is about ethics and the survival of society as a community for all citizens. It builds on the ideal of human rights and social justice. Regardless of resources and background, all children have the right to experience being part of the community in which they are placed. Children that are included experience the joy of being part of and contributing to activities and relationships of the community. Inclusion is succeeded when children experiences having an academic and social outcome of the participation within the community. It is about experiences of belonging. Nielsen (2013) claims that daycare and schools are responsible for inclusion in the way that they as societal institutions provide for the individual a place within a 
community and enhance the foundational solidarity amongst the people that populate society.

\section{Belonging}

In this chapter, I have argued that all students are at risk of feeling and being excluded, and that inclusion has to do with participation, options for action, and the feeling of belonging. Belonging has emerged as a key idea in educational research around dropping out (Thomas, 2012), and is often closely aligned with the concepts of academic and social inclusion. Traditionally the concept draws on both psychological and sociological traditions to inform our understanding of these issues. As Thomas (2012) suggests:

... the psychological literature is used to define belonging at the individual level, while the sociological literature is used to explain how the potential mismatch between a student's background and that of the institution may result in students not feeling like they belong, and leaving early.

I would like to emphasize the importance of not only think of belonging as an individual emotion or feeling, but as a constructed relationship, that regardless of students' background can be established. The creation of belonging, however, entails attention to the ethics of actions and communication. This is to both to build on and go beyond both the individual level and the sociological level, by adding a communication and agency perspective.

At the sociological level belonging is understood in relation to student backgrounds and institutional cultures. Thomas (2012) draws on the work of Bourdieu to explore how his theories of cultural capital and habitus view the problem structurally, as embedded in the way that higher education institutions function. Cultural capital incorporates ways of speaking, behaving and interacting, which are learned through interactions with family and social institutions such as home and schools (McLaren, 1989; Meadmore, 1999) and is, therefore, class-related. In this view, 'habitus' is the disposition to act in certain ways determined by cultural capital and is the embodiment of cultural capital. Educational institutions have an identifiable habitus (Reay, David \& Ball, 2001), which incorporates practices that mutually shape and reshape the institutions with their students, their 
communities and the wider socio-economic cultures of their catchment areas (Reay, David \& Ball, 2001, para 1.3). Thomas (2012) argues that students whose habitus is at odds with that of their higher education institution may feel that they do not fit in, that their social and cultural practices are inappropriate and that their tacit knowledge is undervalued, and they may be more inclined to withdraw early. I appreciate the focus on "ways of speaking, behaving and interacting", but I am concerned that such a view paves the way for a far too deterministic understanding. It is not that culture and habitus do not exert influence, but I wish to pay attention to the much more fluid, flexible, emergent and contextual rise of "feeling of belonging" that unfolds from specific dialogical practices. This points towards a relational view of belonging and paves the way for a more ethical view of student retention and success.

A step on this way is what Thomas refers to as "belonging" at the individual level that recognizes students' subjective feelings of relatedness or connectedness to the school or institution. Referring to Vallerand (1997), Thomas states that belonging "involves feeling connected (or feeling that one belongs in a social milieu" (Vallerand, 1997, p. 300). It relates to "the extent to which students feel personally accepted, respected, included, and supported by others in the [school] social environment" (Goodenow, 1993a, p. 80). Belonging is also characterized by regular contact and the perception that interpersonal relationships have stability, affective concern, and are ongoing (Baumeister \& Leary, 1995). By quoting Goodenow (1993b), Thomas goes yet a step further by describing the sense of belonging as:

... students' sense of being accepted, valued, included, and encouraged by others (teacher and peers) in the academic classroom setting and of feeling oneself to be an important part of the life and activity of the class. More than simple perceived liking or warmth, it also involves support and respect for personal autonomy and for the student as an individual.

The focus here shifts from the individual student to the relationships among teachers and students and to the ongoing creation of belonging. Belonging becomes a co-creation of mutual positive feelings and actions and a matter of creating ethical relationships. Thus to satisfy the need to belong, strong and positive interpersonal relationships are essential. Taking into account the educational training of school professionals, the power relation and 
the moral purpose of education to offer qualified schooling for all students, the responsibility of creating a sense of belonging is mainly one of the school's and the school professionals.

Based on her research, Thomas states that staff are key to enabling students to participate and feel like they belong, and to a high quality learning experience (Gibbs, 2010). The research project found that the introduction of an intervention designed to improve the student experience can bring with it an implicit criticism of existing practices, which in turn can put staff on the defensive, and disinclined to engage with new initiatives. Thomas argues that working with retention and preventing dropping out requires working with 'staff capacity' for involving students and nurturing a culture of belonging. School professionals are crucial to students feeling they belong, but Thomas's research also shows that "staff need recognition, support and development, and reward to encourage and enable them to engage students and nurture their sense of belonging" (p. 77). This suggests that new approaches and interventions should be introduced sensitively, recognizing the professionalism of staff and the time involved, providing support and development, and offering reward for their efforts. Drawing on the wider learning and teaching literature such as Gibbs (2010) and Dándrea and Gosling (2005), Thomas concludes that staff engagement is a crucial element of student engagement, belonging, retention and success, and one that needs further examination.

\section{Becoming somebody}

It is not to be mistaken that schools are important sites of socio-cultural identity production for youth and hold a huge responsibility for the kind of identity they offer students (Smyth \& Hattam, 2004). Wexler (1992) made clear that what students are doing in schools is ultimately best described as becoming somebody (p. 7). Students are not struggling to become nobody, but want to be somebody, a real and presentable self, anchored in the verifying eyes of their friends. Wexler (1992) explains becoming somebody as an organizationally patterned process of production that uses cultural resources deeply ingrained in more pervasive societal structures of inequality and difference. The product of this process is identity, selfhood, the "somebody" which the students work to attain through their interactions in school. The becoming somebody is the organized shaping of a distribution of images of identity. Although not capturing the full picture of a person's self, the images make a difference for how the student defines himself and is reciprocally defined 
by and defining of friends, teachers and parents. Wexler (1992) found that these images of self are stereotypes, relatively undefined, almost caricatured types of social identities. But, students and teachers work with them and produce them in the course of their interactions. Single behaviors, words or other kinds of signs become representative of the self. Wexler talks about the identity "tracks" in schools, where for "most people the identity image production process consists of amplification, distortion, condensation, representation and diffusion of partial signs that denote full identities" (p. 9). Wexler argues, that these practices are highly structured, dividing youth within class and gender into identity types which are the "somebody" that you have become. This self-realization is not ordinarily a case of mistaken identity, but culminates a build-up of "suitable signifying repertoires of language, speech and action that qualify for a typification of identity" (p. 9).

The school system/culture sets up standards or values and social instruments to achieve them, moving and shaping identities and the interactional resources used in their accomplishment. Wexler (1992) exemplifies that "good kids" get detention, but "burn outs" and "scum" are processed, defined and recycled within the detention punishment structure. Likewise, "elites" and "stars" are created in the corridors of gymnasium. The types of selves are not random, but set by the central image of the school and the organizational devices used to achieve its image. Through stratification, a binary division between those students who will become - according to the social class and organizational emblem - winners and those who will be losers, are made.

However students contribute to their own self-production by the interactional labor they perform, there is a structured class polarization of students through which the identity tracks are hierarchically arranged and divided between good and evil. "Losers", "drop-outs" and "good kids" are organizationally produced. What Wexler (1992) describes is the structured processes of interaction through which a limited number of stereotypical and stratified identity images are produced. Emphasizing that educators must pay attention to the implications and seriousness of this identity production in schools, Wexler points out that schools are one of a very few remaining public interactional spaces in which people are still engaged with each other in the reciprocal, though organizationally patterned, labor of producing meaning - indeed, the core meaning of self- identity (p. 10).

Wexler discovered the production of identity in schools was linked to social class and gender. However utterly important, this study exemplifies that the distribution of identity is not necessarily linked to social status or gender, since also middle class youth are problematized, pathologized and excluded. Despite their middle class social status, these 
students become "culprits" not worthy of inclusion - or not possible to include. As such the process of becoming somebody that is structured for them, positions them in at-risk positions.

If not determined by class and gender, what then creates this self-production? What I am suggesting is to look at the communication and ways of thinking that are performed in the courses of events, where (middle class) students are appointed as problematic and positioned in at-risk positions.

Davies and Harré (1990) talk about language as speaking us into existence and constituting our personhood. What is said holds the power of putting others into specific positions. Even though class and gender are important influencing powers, this study points out that language and communication are just as strong in creating the processes of becoming somebody for students. Where class and gender as fixed structures overlook the importance of relationships and communication, social constructionist perspectives make visible how people "become" in communication and relationships.

Positions and relationships are closely dependent as explained in the words of Winslade and Monk (2001):

In each utterance we make in a conversation, we offer others positions from which they may relate to us. We issue them position calls ... We can think of these positions as participants' physical orientations to each other that express relational influence; that authorize the other to speak or not to speak, or to speak only in certain terms; that allow what we say to count or not count; or that limit or widen our possibilities for acting in our own worlds. This is the sense in which language, as Bronwyn Davies suggests, speaks us into existence and constitutes our personhood, as we use it to communicate with others (p. 121).

The important point here is that in conversations we not only speak based on "who we are". We speak from the position we are temporarily invited into and occupying. In this sense people become who they are due to the relationships in which they engage. The story presented in chapter 1 gave us a clear example of how a school by a certain use of language "speaks a student into existence or personhood". The communication unfolds in such ways that the student is offered some specific positions and possibilities of becoming somebody, while others are denied. Smyth \& Hattam use the expression of becoming somebody as the development of personhood, or of significant characteristic or identity. In this case, the 
positions offered to the student made ways of becoming somebody that is not normal, not properly raised, not moral, not nice, not worthy of respect and not possible to understand.

Also Smyth \& Hattam (2004) state that silenced voices of students in schools need to be understood in relation to a socio-cultural milieu in which youth policy is based on youth as "trouble" (Cormack, 1996). Roman (1996) argues how media representations of youth promulgate moral panics about "juvenile delinquency", "gang violence", "students with special needs" and "at risk" students, to name only a few that render young people in schools as the subjects of pathology, deviance or blame. As Fine (1994) explains, this process of stereotyping banishes many students to the margins of school community, because they are "represented as unworthy and immoral, or pitiable, victimized and damaged" (p. 74).

This is a wider explanation than the one of class and gender. It points towards dominating discourses or lines of force that interfere, push or legitimize the actions and utterances of the school professionals that positions students in at-risk positions and exclude them from the school.

\section{A preview of chapter 4}

In chapter 4 I shall lay out the methodological considerations and approaches that have guided the collection of data, the creation and validation of the eight short stories and the design of the analysis. 
Chapter 4

Methodology 


\section{Research Methodology}

In this study I have so far developed an account of the contextual, theoretical and practical backgrounds that can serve as the basis for researching invisible exclusionary practices in school-family interactions. I now need to turn to the task of articulating a research method appropriate for the study. The first part of the chapter will contain an account of the methodological inspirations and how these ideas have been used to pursue this objective. The second part describes how I conducted the data collection, and created the analysis approach.

\section{Voiced research}

In chapter 3 I elaborated more specifically on the conceptual parts of voiced research. In this chapter I touch upon the methodological aspects.

Smyth and Hattam (2004) claim that the explicit agenda of voiced research is to reinsert opportunities for expression that otherwise have been disenfranchised. In research, as well as policy, there is a continual struggle over whose views get to be represented, and smaller voices, those which are less audible, are easily drowned out by others that are louder, more dominant, and putatively more legitimate. Who gets to speak for and on behalf of, for example, exiled students and who gets listened to is an artefact of power and who exercises it (p. 25). In this study it is the "subjugated knowledges" of excluded families that, while considered unworthy by those making policy, ironically hold the promise of providing the most powerful insights/explanations for exclusionary processes in response to interactive troubles.

Because of its commitment to a more democratized research agenda, voiced research has to be constructed in a way that provides a genuine space within which subjugated voices can reveal what is real for them. Therefore, as Burgess (1988) argues, research questions can only really emerge out of purposeful conversations, rather than structured (or unstructured) interviews. Smyth and Hattam (2004) claim, that traditional research interviews, where the researcher asks the questions and extracts data from the interviewee, has all the wrong characteristics for a more participatory approach. However, in voiced research the researcher often does not have pre-formulated questions, but is confident that the interviewees have the capacity to co-construct "sufficiently respectable" questions. Thus, voiced research represents a significant reversal of the way power 
generally tends to operate in research projects, where the researcher "knows", and respondents are expected to willingly comply in supplying information.

Thus, in this study it was my intention to provide a space of enunciation to excluded families and, as we shall see through out this chapter, by engaging in research conversations around our shared experiences with exclusion, stories were formed as well as a coconstruction of ideas on how to investigate and make sense of the processes leading to exclusion.

\section{Research design}

Choosing a research method is closely connected to the nature of the data and the purpose of the study. In general, research falls into two categories: qualitative and quantitative research designs. The first has to do with understanding phenomena, for example, invisible exclusionary processes in schools, as is the case in this project. The latter has to do with studying the extent, variations, numbers and outreach of such phenomena, for example how many families are being excluded, in what circumstances, how often it happens and to what extent. It is not my intention to examine these questions in this study. Therefore, I chose to use a research design that was qualitative in nature. There are many ways of choosing a method for research, even within qualitative research designs; hermeneutic, phenomenological, social constructionist, and so on.

From a social constructionist framework, research is seen as an emerging, relational process that is responsive to stakeholders as well as to new insights learned along the way, to sudden events and whatever else might occur (McNamee, 2014; Gergen, 2015) However, looking at processes of communication and relating in school-family relationships requires a research design capable of grasping and exploring micro-processes in interactions. This points towards specific kinds of qualitative research designs that are based on the kind of inquiry that is relational, narrative and responsive to the continuous changing context of the study. Among these are coordinated management of meaning, positioning theory, and narrative constructionist Inquiry that altogether served as my inspirational material. In the following sections, I shall refer to these inspirational sources, beginning with narrative constructionist inquiry, and how they were used to develop an approach to analysis. I could also have referred to these approaches in the literature review, however by emphasizing "the hows" of these theories, focus is put on methodological considerations, and thus they are presented in this chapter. 


\section{Narrative Constructionist Inquiry}

According to Sparkes and Smith (2008), constructionist inquiry is a complex and varied field of scholarship where one dimension is narrative. It is not easy to give a clear-cut definition of story or narrative. Sparkes and Smith (2008) use the word story when referring to actual tales people tell, where in contrast, narrative is delineated as a dynamic structure embedded in society.

It is unlike a chronicle, a report, or a question-and-answer exchange, but a cultural frame, frequently taken for granted, that comprises various particular stories and that has, for example, a plot sequence of events that is temporally orderedcharacters, a consequence, a point, intentionality, and a teleological quality or a valued ending.

(p. 311, notes, 1)

Sparkes and Smith (2008) state that because narratives exist only in particular stories and all stories are narratives, the distinction is hard to sustain. Narrative constructionist inquiry has partly developed in response to the crises of representation and legitimation and partly as a consequence of a moral concern with imagining new, different and better ways of living. Bruner (1990) explains that narrative can be understood in terms of both a way of telling about our lives and a method of knowing. Sarbin (1986) argues that human life is storied, and narrative is an ontological condition of social life. In the words of Sparkes and Brett (2008) that is to say, we live in story-shaped worlds. In significant ways, narratives constitute human realities and our mode of being, as they help guide action and are "a socio-culturally shared resource that gives substance, artfulness and texture to people's lives" (p. 295). They form the basis for and pave the way for who we are and what we might or might not do, as well for who we might become. As McIntyre (1981) states, closely connected to these concerns has been the growing awareness that a person is essentially a storytelling animal. McAdam (2006) adds that humans naturally construct stories out of life. Such ideas fueled the development of narrative studies into various fields inside and outside research, including therapy, organizational development and leadership training. Gubrium and Holstein (1998) claim that epistemologically, narrative has also come to be understood in terms of either theories or methods and as Bruner (1990) states, narrative has emerged as both a way of telling about our lives and a method of knowing. 
Whilst presenting a series of short stories told by parents caught up in interactive troubles around their child's schooling, this dissertation is both a story and a narrative in itself. Narrative constructionist inquiry serves as a promising approach that gives the possibility of capturing insights and producing new knowledge about how exclusionary processes in school-parent relationships evolve, as represented in the stories. Gergen (1999a) argues that the primary emphasis of narrative constructionism is not on cognitive scripts or the inner worlds of individuals, but on narratives as vehicles through which our world, lives, and selves are articulated and the way in which such narratives function within social relationships. This perspective stresses narrative as a relational, sociocultural phenomenon and form of social action. Gergen (1999a) continues that narratives generate meaning by virtue of their place within the realm of human interaction.

All the storytellers in this study generate meaning out of meaningless experiences and express agency by engaging in the active and relational process of re-storying their experiences. Accordingly, by co-creating their stories and subsequently analyzing them, I seek to generate meaning of it all - both their stories and my own experiences - and together we enact agency as well, by sharing our stories in this dissertation. As Gergen (1999b) points out agency is neither "in here" nor "out there", but realized within the doing of storytelling relations.

Sparkes and Smith (2008) argue that meaning and agency are conceptualized as an achievement and as artfully created in and through storytelling and not necessarily as indicators of wellbeing. Likewise, "experiences such as emotions and memories are not merely psychological states but also narratively performed social enactments" (p. 299). Narrative constructionism gives great attention to relatedness or relationships and considers narratives as forms of social action through which human life and our sense of self are constructed, performed and enacted. Such things as emotions, memories and selves, are regarded as constituted through storytelling, and become visible to ourselves and others through joint actions, such as storytelling. As Sparkes and Smith (2008) claim, narratives are culturally situated and rely for their success on culturally-shared conventions about "tellability", language, and the hearing of stories, even though they may be felt and expressed as if they are highly personal (p. 300).

One important point here is, that even though the stories in this study are felt and expressed as highly personal, they bear witness to larger cultural and social phenomena that structure people's lives (here especially, experiences in school). Another important point is the understanding of the concept of the self. As social constructionism gives greater 
attention to relatedness and the social aspects of narrative in the self- and identityconstruction process, the self as an isolated and individual figure does not exist. To cite Sparkes and Smith (2008) citing Somers “.. identities ... do not 'exist' ... Individualism itself is socially and relationally constructed" (p. 300).

Building on such argument offers a framework for conceptualizing narrative identities and narrativity along a number of dimensions, which Somers (1994) names ontological, public and meta. Ontological narratives are the stories that people use to make sense of and to act in their lives. These are used to define who we are, which she claims is a precondition for knowing what to do. One might say, that in the stories there are struggles over "who the students and parents are", and for them "knowing what to do" depends greatly on how the power struggle works out. Ontological narratives make identity and the self something that one becomes, and embed identities in time and spatial relationships (Somers, 1994, p. 618). The deficit narratives about the students that are presented to the families create the "becoming somebody" for the students. Narratives do not come out of the blue, but are constructed and personalized over time. They are drawn from a limited repertoire of available narrative resources that are social and relational. As such, they both derive from and are closely connected to and shaped by networks of relationality, which Somers refers to as the second dimension; public narratives. Public narratives are those narratives attached to cultural and institutional formations larger than the single individual and they are linked to the third dimension of narrativity, which is meta-narrativity. Dominating public narratives in the field of interactional troubles in educational settings are sometimes deficit discourses and pathological perspectives on the individual. This refers to the "master narratives" in which "we are embedded as contemporary actors in history and as social scientists" (Sparkes \& Smith, p. 300). Sociological theories and concepts are encoded within aspects of these master narratives and can be the epic dramas of our times, for example, individual versus society, capitalism versus communism, and barbarism versus civility (Sparkes \& Smith, p. 300). As discussed in chapter 1, Fine (1994) argues that in fighting "the barbaric youth" (the individual), school professionals aim to protect "the civilized adults" (society). However, in many school practices, the civilized adults (society/system) "act barbarically" and do harm to youth (individuals). As such, the stories in this study provide scenarios for the enactment of the epic dramas of our times.

To Gergen (1994) "Language is a social act and self-narratives are linguistic products embedded within conventional sequences of action and employed in relationships in such ways as to sustain, enhance or impede various forms of action" (p. 188). As such, Gergen 
argues, relationships take priority over the individual self (p. 249) and one's identity is formed and transformed by narrative-inspired social relationships. Sarbin (2005) argues that both engaging in formal and informal encounters, the primary medium for the creation and development of relationships is dialogical (p. 208). It is recognized that stories are shaped by culture and may be told differently in different contexts and relationships over time. People have in varying degrees agency and freedom to construct the story they tell and are not slaves of culture, nor are stories determining. What is important here is that despite dominating public narratives, individuals such as school professionals have choices of what stories to tell, and what meta-narratives to draw from. Moreover, a story is "just one story amongst others" and may not be given the power to construct people's lives, but can be challenged, changed, and substituted with better ones.

According to Bochner (2002), people are not condemned to live out the stories passed on through cultural production and institutional traditions. "It requires our stories to be thwarted or contested, if we are to have any expectations of change, any account of conflict, any real demand to account for our actions, and any sense of agency" (p. 81). Yet, people cannot create stories at will, even with agency. Various institutional orders and their representatives, for example, teachers in schools, mandate narratives, each for different purposes and each in different forms. Telling stories about themselves, people draw upon a particular set of narrative resources that are at hand, however they are not equally distributed. People are not free to take up or make up just any story they please, since there are barriers and differential invitations involved. One example of the implications of such an idea is the concept of position calls that was explained in chapter 3.

\section{CMM research}

$\mathrm{CMM}$ is a constructionist communication theory designed to analyze what communication creates. It understands the world as spirals of interactions in which relationships, positions, options for action, and identities are created. Doing CMM research entails looking at communication patterns to see who is talking, who is orchestrating the conversation, about whom and what is centered, and how are people acting towards one another during the exchange? As such CMM research draws on inspiration from conversation analysis (ten Haven, 1990), interaction analysis (Jordan \& Henderson, 1994) and narrative analysis. Sometimes what is studied is not one particular conversation, but a process of interaction and, therefore, the analysis needs to take this into account. I have 
already given an account of narrative analysis, and shall, therefore, move on by saying something briefly about the two other inspirational sources for CMM-research.

Conversation analysis can be conceived as a specific analytic trajectory which may be used to reach a specific kind of systematic insight in the ways in which members of society 'do interaction'. ten Haven (1990) states, that conversation analysis is a disciplined way of studying the local organization of interactional episodes. Its unique methodological practice has enabled its practitioners to produce a mass of insights into the detailed procedural foundations of everyday life. "It has developed some very practical solutions to some rather thorny methodological problems. As such it is methodologically 'impure', but it works" (ten Haven, 1990, p. 1).

Interaction analysis is an interdisciplinary method for the empirical investigation of the interaction of human beings. Investigating human activities such as talk, nonverbal interaction, and the use of artifacts, it aims to identify routine practices and problems and potential resources for their solution (Jordan \& Henderson, 1994).

$\mathrm{CMM}$ is particularly interested in describing conversations or interactions where the people involved tell us what "it makes", what outcome is produced, or what social worlds are created (Pearce, 2006, p. 11). Pearce points out that taking a communication perspective inevitably is to be concerned with four pivotal questions: What are we making? How are we making this together? What are we becoming, while making this? How can we create better social worlds? (Pearce, 2006). These questions are closely connected to 'becoming somebody' within and throughout interactions as well as to finding alternative ways of doing conversations and interactions that lead to better social worlds.

According to Pearce (2006), all CMM research is in general a case study, and in general, all CMM research proceeds through a series of cumulative goals. This is also the case in my study. These goals may be descriptive, interpretive, critical and practical. The descriptive part is naming the problem and telling the stories of exclusionary processes. The interpretive part is - based on the data and analysis - to identify what the implications of the problem means, for example, to society, to school-family collaboration and to student becoming. The critical part is to make judgments of what is better and worse. The practical part is concerning what to do in order to make better social worlds, for example how can school professionals act in ways that call into being flourishing dialogical relationships in school-family collaboration that are inclusionary and not exclusionary. Finally, some CMM research is explicitly practical, asking what we can do to make better social worlds and point towards other alternatives. In this study I emphasize on showing the established, yet 
invisible problem of exclusion, as well as the unintended constitutive effects of it, such as marginalization, stigmatization and school problems, which are known to research, but not linked to the school practices around dealing with interactive troubles. Furthermore, I wish to tap into what could be different; how can school professionals response to interactive troubles in ways that are not exclusionary. Or to take it even a step further: How can school professionals respond to interactive troubles in ways that hold regards for relationships, possibilities and student becoming?

Like other qualitative researchers, CMM researchers use well-known methods for collecting and analyzing data. This might be direct observations, participant observations, interviews, narrative analysis, content analysis, video-recordings, and recalled stories, amongst many others. The field of developing analysis questions within CMM research is more or less inexhaustible, but will have to connect with both the core principles and the purposes of the research, as well as with the nature of the data. It can be combined with discourse analysis and positioning theory analysis, to mention two. But CMM research differentiates itself from most of its intellectual cousins (described in chapter 3 ) in a series of ways. 1) First it looks toward the saying and doings of particular actors in specific contexts. The larger social and discursive structures are seen as made in patterns of specific actions.

2) CMM understands social worlds as inherently meaningful, where 'meaning' is a constituent part of any social action. CMM researchers commit to doing a hermeneutic analysis before engaging in criticism or intervention - and in general follow the abovementioned sequence; description, interpretation, critical, and practice. 3) CMM understands the social world as polygenic and assumes that every saying and doing is meaningful, multiply interpreted and open to re-interpretations. This means avoiding any claims of right or true interpretations. 4) CMM understands the social world as made in a spiraling process in which the two aspects - coordinating actions and managing meanings are irreducible tensions. I shall return to this at the end of the chapter.

In the following sections I shall address how the data was collected by using the method of snowball sampling, how the stories for analysis were constructed, and finally how the analysis was created.

\section{How I collected the data}

Snowball Sampling 
Through my everyday family life I knew of a couple of cases, where students and families had been unintentionally excluded from schools. Thus, I had knowledge of some of the stories even before initiating this study. However, the stories were not made into data and, therefore, I needed to find a way of collecting and creating data suitable for analysis. The method of collecting the data evolved around my own experiences and in my own network. As a field worker, I initiated a snowball sampling (Browne, 2005; Morgan, 2008) simply by engaging myself in conversations with various people around exclusionary processes in schools. The term "snowball sampling" reflects an analogy to a snowball increasing in size as it rolls downhill. Through snowball sampling it is possible to obtain knowledge on issues about which very little is known. Therefore, the method is often used in hidden populations which are difficult for researchers to access, such as socially marginalized groups who are difficult to locate, for example, homeless citizens or users of illegal drugs (Atkinson \& Flint, 2001). It is also used when members are closely connected, for example, in sharing similar interests or involvement in the same groups relevant to the project at hand (Browne, 2005). Through acquaintances and recommendations, the researcher tries to find people with the specific insights and experiences useful to the research. The sampling starts with a first respondent and, through the social network of the first respondent, other participants are identified and invited into the research. These other participants may themselves open other possibilities for an expanding web of contact and inquiry. As more relationships and connections emerge, a plethora of shared information is collected, much like a snowball that rolls and increases in size as it collects more snow.

Snowball sampling has been utilized primarily to overcome the problems associated with understanding and sampling concealed populations, such as the deviant and the socially isolated (Atkinson \& Flint, 2001). Because of their marginalized position in society, it is difficult for researchers to locate these persons and to motivate them into a research project. Snowball sampling functions as 'peer recruitment', where the relations between the respondents secure confidence and motivate willingness to participate. Snowball sampling is an expedient strategy conventionally associated with qualitative research.

Snowball sampling typically consists of a series of stages. I did not directly plan to use this method, or plan the steps in the process. However, looking at it retrospectively, and despite the last item, the process did follow the lines of these steps in a snowball sampling:

- Draft an indicative participation program, often likely to be subject to change.

- Approach stakeholders and ask for contacts. 
- Gain contacts and ask them to participate.

- Community groups may emerge that can be included in the participation program.

- Continue the snowballing with contacts to gain more stakeholders, if necessary.

- nsure a diversity of contacts by widening the profile of persons involved in the snowballing exercise.

In the next section, I shall explain how the recruitment of participants took place.

\section{Recruitment}

As a parent, I had stories of exclusionary processes to offer for this study, and furthermore, I knew of several other families who had experienced being excluded. As parents in the local community, we had shared our hidden, angry and shameful stories in deep secrecy. Common to these conversations, was the characterization of despair, anger and secrecy about what was difficult to explain elsewhere - of not being listened to and acknowledged. My personal experiences not only concerned a difficult collaboration with the school in trying to maintain a worthy position for our child, but also included emotions such as self-blame, distrust of our own parenting skills, devastating sadness, hopelessness, powerlessness, anger towards the teachers, the school and the system. By talking to and listening to other parents' stories, I had learned that I was not alone with these experiences and emotions, and that we - parents sharing our stories of being silenced, blamed, distrusted, and having our children stigmatized - were part of a larger picture that deserved much more careful investigation.

When initiating this study, the conversations that I carried with me changed contextually from just being private and hidden exchanges about everyday life to potentially entailing the possibility of serving a larger purpose. I wanted to approach these parents and invite them into the research project. So I contacted each of them and explained that I was conducting a study around exclusionary processes in schools, and that I remembered having had conversations with them on these issues. After re-telling briefly my own experiences, I then asked them if I could talk with them to recollect their experiences with the purpose of using them for research. I made sure that they had the opportunity NOT to participate, and we talked about ethical concerns and implications for them as a family, if they participated. I also told them that they would have time to think about it and discuss it at home. Then, we engaged in an exploratory dialogue about various hopes and wishes for what might come out of a research study on this topic. It was fulfilling for me to discover how they all 
wanted to participate and how happy they were about the possibility of contributing to make visible the exclusionary processes in schools that had affected them as families in such negative ways.

By starting with my own experiences, I functioned as the first respondent in the snowball sampling. Knowing others and inviting them into the research, and listening to them and sharing our experiences, I included other parents as respondents, too. Then, what turned out to be the case was that these people connected me to others in their network that too had had experiences with exclusionary processes in schools. The next step was to agree with these families, whom I did not know in advance, to engage in a research relationship where I could listen to their stories and share some of my own experiences as well as reflections about researching this topic. In this process, I gathered eight more stories to add the first six.

\section{Participants}

Regarding the last step in the snowball sampling, I had no aim of either ensuring a diversity of contacts, nor of widening or narrowing the profile of persons in the sampling. Who offered themselves to the project, who was invited and who was selected was not a consequence of explicit methodological stringency, but was mostly a random result of chance. I did notice specified traits of the individuals like gender, age, family history, employment, social status and location, as well as elements in the stories. I paid attention to some biases within the method, which had to do with the social location of the families. Some of the parents either had children in the same local schools that I had, or were friends or colleagues to these families - and half of the participants more or less belonged to the same social network. Some of the families lived in other areas of the country, but were naturally connected to the first nominees, either as friends, family or former colleagues. The families in my sample all turned out to be middle-class, well-educated and selfsupporting, and it is likely that this is due to the collection method, rather than to the topic of research.

Nevertheless, it does show that exclusionary processes also involve middleclass families. A question of great interest arises here. If middle-class families are exposed to social exclusion in schools and with harsh social and individual consequences as we shall come to learn in the course of this research, how might these exclusionary processes be experienced by less fortunate families? How might exclusionary processes in schools work 
on socially marginalized families or upper class families alike? These questions call for more research on the topic and I will reflect further on this in the final chapter.

Among the participating families, one parent was a school principal, one was a pedagogue in a kindergarten, one was a vice-principal, two were teachers in public schools, one was a financial director, one was an IT-specialist working as a supervisor, one was a manager in a municipality, one was a director in a non-profit organization, three were selfemployed business owners, one was a high school teacher, one was a military lawyer, one was a farmer, and the last one was myself.

\section{Validity/trustworthiness}

However useful a tool it is for building networks and increasing the number of participants, it is suggested that the success of snowball sampling depends greatly on the initial contacts and connections made. Thus, it is said to be important to connect with participants that are regarded as honorable within the community of participants in order to establish a credible reputation for the research study. I admit that I did not know whether I was considered honorable within the community of participants. Furthermore, it was quite random which parents I got to talk to and when. I took a chance by offering myself as the first respondent as well as being the researcher. But, I do believe that being a Ph.D.-student with personal experiences with the topic of study did help establish a trustful researchrelationship. The fact that I myself had a story to tell imbued confidentiality, accountability and a sense of togetherness that was fruitful for sharing stories. I guess that offering my own experiences and contributing with a story myself, made the other respondents feel confident that I would treat the stories with the greatest respect. Being a respondent myself made clear that my purpose with doing the study was sincere. Together we created a strong commitment to the aim of making visible the exclusion that takes place in schools, and the respondents showed great confidence, that this study might contribute to turning exclusionary processes into inclusionary ones.

\section{Results of data collection}

The amount of time required to make contact was not recorded, but without conducting it as comprehensive full-time research, I had within a few weeks fourteen stories 
and was in contact with participants offering even more. There was much more than I could possibly integrate in the project. However, one story was left out of the initial corpus, as the storyteller regretted half way through the process that there were severe developments in her situation. This led to great new insights for me, which I will address again in the analysis chapter. During the process of analysis, though, I realized that fourteen stories with even more to come, was far too much data for me to integrate. So, when having fourteen stories, I ended the gathering of stories. What I had was what I had - whatever that showed up to be.

When I processed the analysis, I learned that I had collected far too much data and needed to downsize. I decided to omit six stories and the selection of which to include and which to omit was made with regards to a couple of criteria. First, I had committed myself to and promised the first five respondents to make public their stories. We shared a strong wish to initiate a debate around invisible exclusionary processes in schools and the need for professional, effective and relational ways to respond to interactive troubles in schools. Therefore, I would not omit these stories. Amongst the rest, I looked at the variation amongst the stories, together with the level of detail in each of the stories. I wanted stories that were different in various ways; gender of students and the storytelling parents, demographic location, different types of initiating events (bullying, conflict or some other type of interactive troubles), and the like. Based on these regards, I chose the eight short stories that came to contain the empirical corpus from which I have conducted the analysis.

Methodologically, I had to take into account the method of analysis. I wanted to analyze each story by using a spiral analysis, and thus gave myself a laborious and demanding task having integrated eight stories. For the stories omitted, I explained this problem to the parents, and we found it comforting to have had spent time listening and sharing knowledge together. Being supportive of the research, however not directly integrated, they all contributed substantially to the development of the analysis questions, my reflections and realization of the importance of this study. I am confident that having had the conversations and narrating their stories together did help them recover a bit from their agony.

As mentioned, it was not possible to make room for all the stories that were offered. I stopped the snowball sampling when I had fourteen stories, and later downsized the poll to eight. I do believe that these eight stories are comprehensible and adequate to raise my arguments and to get to the point. Collaboratively with each storyteller, we worked on creating a title for their story. Thus, the final eight stories to be presented and analyzed are: 
Story 1 . When a student is silenced

Story 2: When a student is made into a villain

Story 3: When a family becomes insignificant

Story 4: When a student becomes invisible in school

Story 5: When a student becomes excluded by a teacher

Story 6: When a student becomes persecuted

Story 7: When a student becomes the scapegoat

Story 8: Why are they not listening?

Still, more stories kept coming to my knowledge. The problem was how to stop the snowball from collecting more snow, rather than finding enough participants with relevant stories. After downsizing to eight stories, a colleague to one of the first participants contacted me to share his story and tell me that he knew of two other cases in his network. Just recently, my childhood friend told me of her experiences with her two daughters, and that she had two colleagues experiencing exactly the same thing and suffering severe frustration and overload. A participant on a leadership training course that I teach heard about this research and wanted to tell his story around his son's school, as well as another participant suffering from the bullying of her child and the school's neglect of it. At a dinner party recently, a father recollected his experiences of being mocked, humiliated and put down by one of his teachers and how that had haunted him throughout his life. My brotherin-law and his family just moved one of their daughters, after two years of distress and frustration concerning severe bullying in the class, scolding by teachers and neglect from the school and the teacher to acknowledge it. His child had increasingly refused to go to school, experienced stomach aches and eventually the situation evolved into a coercive conflict with the principal. So while, I have stopped collecting more data, still new stories keep coming to me like a snowball that continues rolling and cannot be stopped. I do keep listening, but cannot integrate more stories into my data sample.

\section{Constructing a text for analysis}

After I connected with each of the storytellers, we personally agreed on how to communicate and collaborate on the construction of their story. The interviews were structured as an everyday conversation. Sometimes I met with a parent and we went for a 
walk. Other times I engaged in long telephone conversations and in long emailcorrespondences. I did not record the conversations, but took notes of details and the line of events in each case. I narrated each story based on what I was told had happened. It was not always easy, since the stories were complicated, fragmented and detailed. Often the storyteller tried to recollect specific sentences that teachers, principals, their child or they themselves had said. When each story was narrated and written in text form, I sent it to the storyteller for them to verify, comment or correct. All of them had comments and suggestions for corrections, improvements and the like. Some were concerned with the accuracy of details, others with anonymity. In some cases, we met again or via telephone or email talked the story through, made changes and eventually co-created the final story. When constructing a representation of a series of events as is the case in these stories, not everything can be included within an appropriate frame. We needed to focus each story, integrating some things and letting go of other things, perhaps equally important to the storyteller, the case or the research. Thus in each case, we co-created what was to be included and what was to be left out - but always with great regard to the storytellers' wishes. In all cases, we agreed on which parts of the story to emphasize, which to explain otherwise and which to let go of. Only when approved by the storyteller, was the story finished. After the text was settled, I translated each story from Danish to English. I used dictionaries and google translate. After this, I sent each story to each storyteller for them to confirm and approve the English version as well.

In terms of the narrating of my own story, I had shared our own experiences of exclusionary processes with each of the participating parents, and through this process of narrating, explaining, re-narrating and repeating, several stories took form. In collaboration with my supervisor, John Winslade, I decided which of these experiences to use in the study. Then I wrote down the story and translated it to English, so that I could discuss the text with John. Through this process we found a way to maintain anonymity and I re-wrote it in a third-person-perspective. Then John helped me refine it, and finally I blended into the corpus of stories.

\section{Ethical issues in data collection method}

When collecting data and producing the text of the stories, ethical concerns arose. The problem of representation is concerned with the way people are represented in research. A person is defined by the stories he tells about himself as well as by the stories 
that are told about him (Blatt, 1981). Too often, stories are told about people and the emphasis is on the voice of the professional, not the voice of the person (Blatt, 1981; Kliewer \& Biklen, 1996). This is much the case in the stories in this study, where we come to learn that the stories about students in school are based on the voices of the professionals, with the harsh effect that students and parents are silenced. As I talked to the parents and listened to their accounts, a counter story emerged with more emphasis on the perspectives of the family. By listening to these voices, we come to learn that the becoming of the student is - if not determined, then - substantially influenced by the dominating stories told about him by the professionals in school. My aim was to convey the parents' stories as loyal representations of their experiences, and so I emphasized their perspectives. Each parent had had great influence on their own positioning in the stories, since these were their stories. This led to concerns around the representations of teachers and principals, especially, but also students and others who had not had the chance to read and comment or give interviews. Being represented, but not having had a say on how, raises many ethical concerns from a researcher's perspective. If the students were to read this dissertation in the future, how would they feel about the representation of themselves? What about the teachers and principals? How would they feel about the way they were presented and understood in the stories? What would they have added and what would they have wanted to leave out? The problem of representation is less prominent in stories where teachers and school professionals play a more diffuse role or are seen more as a system, than in those stories where they play a more concrete role in the line of events leading to marginalization. Acknowledging this as an ethical dilemma, I still came to the conclusion that telling these stories was important. I wished to show how ways of interacting in schools produce exclusionary processes and that teachers, had they acted differently, might have created inclusionary processes instead. This is not to point at teachers as those causing the problem, but to be able to tell the stories in the first place. Compensating for this dilemma, I strove to co-construct the stories so they emphasized the parents' emotions, reflections, hopes and fears, whilst assisting the parents in recollecting what teachers and principals said and did as factually as possible - and avoiding interpreting teachers' possible intentions.

\section{Confidentiality}

In relation to collecting data, ethical considerations clearly appeared as questions of anonymity, trust and confidentiality. Questions of confidentiality and trust were issues that 
we dealt with initially as well as along the way. Some confidentiality was gained by explaining how I would anonymize the stories and that I as a researcher would treat the stories in strict confidence. I gave my word that I would not discuss their cases with others in such ways that recognition was possible. We agreed to randomly change gender on people in the stories. Any names for places and institutions were deleted and, if possible, other "things" that might point towards specific schools or persons were omitted. This also applies to the stories omitted from the corpus.

Developing a research relationship through our shared experiences built trust and a shared feeling that this was important knowledge to bring out, and that it was remarkable that these things go on without the rest of the world knowing. The participating parents expressed satisfaction and happiness with finally getting to share their stories so that things could change and hopefully so that others would not have to experience the same things. Common to their responses was a relief to be able to talk about these experiences without someone judging them. What was the strongest motivation it seemed, was to discover that exclusionary processes in schools is a legitimate research topic, that had only previously been invisible and hidden, but was now regarded as of considerable importance.

\section{Informed consent}

In every method there are ethical concerns in relation to collecting the data, producing the text of the stories, as well as analyzing and drawing conclusions from the analyses. In qualitative research, apprehension around feelings of compulsion and consent are reviewed for potential ethical dilemmas, and recommendations for research processes are made. Both in the initial making of contacts and throughout the research process, I offered opportunities to the storytellers to withdraw from the project. However delicate a topic, all the parents that I corresponded with had agreed to participate in the study. As mentioned, one parent chose to withdraw from the study half way through. This parent was a single parent to three boys, all having had difficulties in school, however of different kinds. She was unemployed and on social services which means with limited economical resources. She was suffering from a longitudinal cancer-treatment. Two of her boys were young adults and on their way to becoming craftsmen. She was very proud of them as they had created a life for themselves, despite school problems though their childhood. The story that she had wanted to contribute concerned the youngest son, who had been suffering from bullying, isolation and poor learning outcomes for years. The story was continuing as we 
corresponded, and we did not know how it would end. The collaboration with the school had been very difficult for years. The reason she wanted to withdraw from the study was that her son's situation had worsened both in school and at home. The school had punished him in various ways for not being motivated and due to his responses to this, he was sent to a doctor, then a psychologist, then a psychiatrist and by that time he refused to go to school any more - this was one and a half years before graduation. The mother felt that neither the school, nor the municipality were collaborative or helpful, and she could not find the resources to be part of the study, as she had to economize her energy, focusing on supporting her son and finding ways to help him. Comparing her situation with the other families in this study points toward some important differences. One is that this family was economically struggling (not middleclass). Another, that she was struggling with severe illness. And a third one was that the mother had not found strength (words and knowledge) in fighting for her son in school, but more or less powerlessly was witnessing the stigmatization, marginalization and finally pathologization of her son to such degree, that he broke down. The end result to this point was not only exclusion from the school, but exclusion from the educational system and social isolation.

\section{Researcher bias and positions}

The "indicative participation program" only concerned one eligibility criterion for participants to meet, which was to have had experience with exclusionary processes in schools. It was perhaps a little unorthodox but, due to having experiences with exclusionary processes in schools myself, I became the first respondent. As such I served in a double role as both a respondent and the researcher, similar to what happens in auto-ethnographic research (Ellington \& Ellis, 2008).

In this double role, I felt overwhelmed by the depth and scope of the research topic, which showed itself to be much larger and more important than first assumed. I discovered that the negative social impact of school-family conflicts were far-reaching and had potentially devastating implications for the students, their siblings and parents. I learned that some families - otherwise well-functioning - over time developed depression, ulcers and an increased level of family disputes and distress as a result of conflicts in schools. Each story that came to my knowledge made me feel sad and reminded me of my own experiences, which, compared to some of the other stories, seemed far less severe. I learned that most of these families were ashamed about their powerlessness and distress, 
and that it had prevented them from talking to others about it. The relief and empowerment of telling me their stories was not to be mistaken or underestimated. Some parents could not hide their emotions and since I had a hard time with that too, these conversations were highly tense. On the other hand, my experience was that it made a huge difference to these families, discovering that the phenomena that they were talking about, were not just something tied to them personally, but something that happened to many more families.

It might be argued that being both a respondent and the researcher entails too much bias. Nevertheless, I would like to state that for this study it was actually quite important and a positive thing. Due to my position as a respondent having experiences with exclusionary processes in schools, I was in particular well positioned to talk with the other respondents. Due to my own experiences I was alerted to many issues and emotions, both in regards to remembering and recollecting their experiences and in conducting dignifying conversations around the co-narrating of their stories. Furthermore, it was empowering and emancipating for the families to be given an overall frame (exclusionary processes) for what they had experienced. Many other things were in play, such as bullying, conflicts, friendships, loneliness, and another frame would have emphasized other aspects of the events. Therefore it is a open question whether another researcher - perhaps not a parent - could have done the same, or whether the stories then would have been different.

\section{Benefits of snowball sampling}

It is acknowledged that through snowball sampling it is possible to make inferences about social networks and relations in areas in which sensitive, illegal or deviant issues are involved. Equally important is its utility in exploring a population about whom little is known. A range of advantages have been claimed for snowball sampling. A few of the most acknowledged advantages are that: 1 . it can locate hidden populations. It is possible for the surveyors to include people in a survey that they would not have known otherwise. 2 . It can locate people of a specific population, where there are no lists or other obvious sources for locating members of the population as with, for example, the homeless and users of illegal drugs. 3. It is low cost and economical, efficient and effective in various studies (Atkinson \& Flint, 2001). As the first respondent is used to locate the hidden population, the researcher does not have to invest money and time in the sampling process. Snowball 
sampling does not require complex planning and the staff used is considerably smaller in comparison with other sampling methods.

In this study collecting the stories emerged naturally and quickly. The problem was not to find the stories, as they kept and still keep coming to me, but to stop collecting and integrating more stories into my data sample. Working my way through the research, I found further advantages. Through discovering the exclusionary processes as part of a larger picture and acknowledging it as a field of research and not as individual and single situations helped build a healing community amongst the excluded parents. Narrating the stories for research and discussing them for the purpose of analysis strengthened the participants' agency and enabled the sharing of what were previously shameful experiences as now important research material. A side-effect of the sharing of experiences without being judged was the restoration of relationships within and around families, and this helped make peace with the past.

\section{Limitations of the data collection method}

Every research method has its disadvantages, and it is assumed that snowball samples are subject to numerous biases too. For example, people who have many friends are more likely to be recruited into the sample. Let me sum up some of the most common biases. As the first participants have a strong impact on the sample, snowball sampling is inexact, and can produce varied and distorted results. The method is heavily reliant on the skill of the researcher conducting the actual sampling, and on his or her ability to vertically network and find an appropriate sample. To be successful requires previous contacts within the target area, and the ability to keep the information flow going throughout the target group. The method is not a random method in the traditional way, and snowball sampling contradicts many of the assumptions supporting conventional notions of random selection and representativeness. However, it is a useful way to access social systems beyond the researcher's ability to recruit randomly. Snowball sampling is thus inevitable in some social systems. It is vague with regard to overall sample size, and there is no way to know the total size of the overall population. There can be a lack of definite knowledge about whether or not the sample is an accurate reading of the target population. Thus, targeting only a few selected people is not always indicative of the actual trends within the result group. As the respondents locate the hidden population, the researcher has very little control over the sampling method. Thus the method becomes mainly dependent on the original respondent 
(Atkinson \& Flint, 2001; Morgan, 2008). However, in this case it turned out to be an efficient, smooth, flexible and relational process as described in the previous sections.

\section{Designing the data analysis}

In this section I shall address how I will do the data analysis in chapter 5 . An analysis is supposed to offer a way to look and make sense of the object or phenomenon studied with the purpose of gaining new insights. In this case the phenomenon is the unintended exclusionary processes and what in the communication and interactions in school-family relationships produced it. Since this question has not yet been addressed, we simply do not know. In order to understand the micro-processes of language and how ways of thinking and communicating model certain ways of engaging and relating, it requires the use of appropriate analysis approaches/theories. What is needed is to look into the exclusionary forces in the communication between schools and families. For this purpose I have created a spiral analysis integrating positioning theory, narrative inquiry and coordinated management of meaning (CMM) to analyze the stories to try to make sense of them. A spiral analysis is a way of describing interactions or conversations, where about people involved tells us what "it makes". What it makes refers to what it was like and how it affected the persons involved to be part of those interactions (Foster \& Bochner, 2008).

Aligned with Foster and Bochner, CMM research is particularly interested in describing conversations or interactions where the people involved tell us what "it makes"; what outcome is produced or what social worlds are created (Pearce, 2006, p. 11). This might involve a description of the process in which more stable forms, such as positions, relationships or stories, are made as well as what is included and excluded, what unintended consequenses are experienced, and so on. Such analysis of results provides a powerful base on which to understand and act wisely into specific situations, which is the overall purpose of CMM research (Pearce, 2006, p. 11). Other results of a successful CMM research may include a description of the patterns in which tensions in the spiraling process are played out.

The idea of spirals correlates with circularity, or circular thinking (Bateson, 1972), which refers to the understanding of events happening in parallel, interrelated, reciprocal and simultaneous. Many step-theories or phase-theories make use of linear representations or proceedings, such as $A-B-C$ and so on, which distorts a spiraling, reflexive process. The 
spiral representation makes it possible to portray a line of events or interactions partly in a linear and partly in a circular way.

Figure 4.1. A spiral analysis:

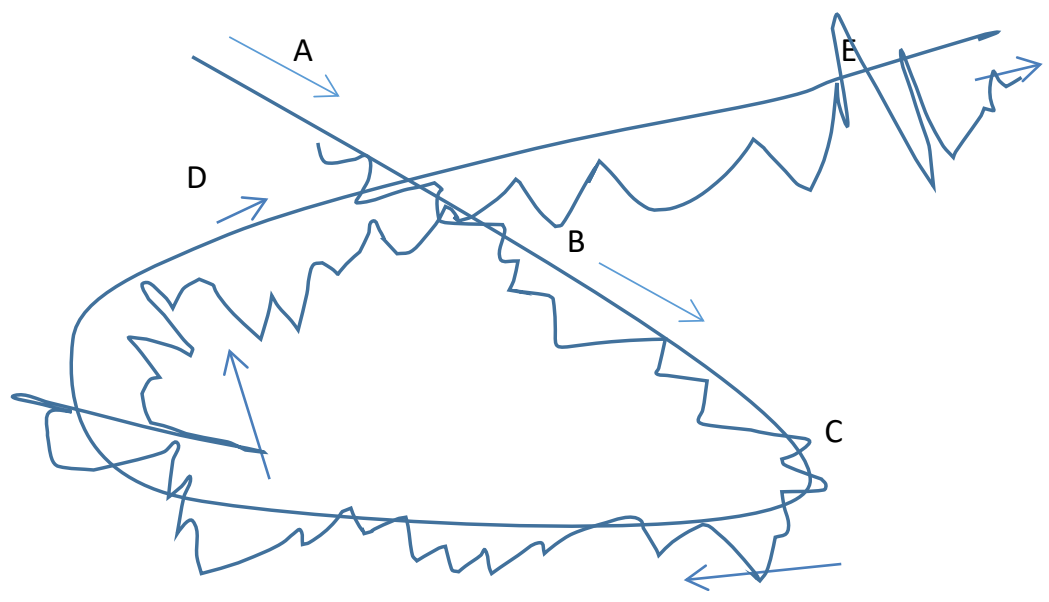

Doing a spiral analysis, integrating narrative analysis and positioning theory, of the eight short stories makes it possible for me to look at the school-family interactions to say what happened that made the interactions ultimately exclusionary, and how school professionals might have acted differently to create inclusionary processes instead.

Pearce (2006) points out that taking a communication perspective inevitably is concerned with four pivotal questions: What are we making? How are we making this together? What are we becoming, while making this? How can we create better social worlds? These questions are closely connected to 'becoming somebody' within and throughout interactions as well as of finding alternative ways of doing conversations and interactions that lead to better social worlds.

Pearce's questions are inspirational for understanding what is going on in the interactions. In regard to the two first questions: What are we making? And How are we making this together? I wish to look at (i) how the interaction is contextualized by the school professionals, (ii) how the problem story is laid out by the school professionals, (iii) how parents' and students' voices are invited, involved, valued and used by the school professionals, (iv) how parents are positioned by the school professionals, (v) what options for actions are formed for the parents, and finally (vi) what the outcomes of the exchanges were. In regard to Pearce's third question: What are we becoming, while making this? I wish to look at the becoming somebody of the student during the exchange and as a result of the 
exchange. In regard to the fourth question: How can we create better social worlds? I wish to look at bifurcation points in the exchanges, which are moments where the school professionals might have acted differently. Bifurcation points are "moments of choice", because they offer a choice in which the school professionals might have acted in a way that made more prosperous and flourishing interactions and outcomes possible.

The analysis questions are then organized in three paragraphs;

\section{A. What are we making and how are we making this together?}

1. How was the interaction contextualized by the school professional?

2. How was the problem story laid out by the school professionals?

3. How were parents' and students' voices invited, involved, valued and used by the school professionals?

4. How were parents positioned by the school professionals?

5. What options for actions were formed for the parents?

6. What were the outcomes of the exchange?

7. What were the bifurcation points in the exchanges?

B. What are we becoming while making this?

1. How was the becoming somebody of the student constituted?

\section{How can we create better social worlds?}

1. How can we ${ }^{10}$ respond differently to interactive troubles?

\section{A preview of chapter 5}

In the following chapter, I shall present and analyze the data in the form of the eight short stories. I will address the first research question (What ways of thinking produce the exclusionary processes?) by the use of the analysis questions A. 1-7 and B. 1. The second research question (How can school professionals change exclusionary processes into inclusion in a way that supports students becoming somebody?) will be addressed in chapter 6 by the use of analysis question C. 1 .

\footnotetext{
${ }^{10}$ The word WE refers to school professionals here.
} 
Chapter 5

\section{Images of exclusion}




\section{Introduction}

In this chapter I have the honor of presenting the data, which consists of eight short stories collected for the study. First, I shall present and analyze the first story. I will apply the analytical questions in paragraph $\mathrm{A}$ and mark the findings in textboxes in the text. After this, I will elaborate step by step on what is created in the interaction and how it could be different. After this, I will present and analyze the rest of the stories one by one. Based on these analyses, we shall look into what can be said about the pattern of practices that reveals itself though the overall analysis. After describing the pattern, I will try to go behind it to look for the basic assumptions that are producing it and that are leading the actions and events under study. Finally, the results are summed up in the conclusion and then contested with some likely objections to be addressed.

Altogether the stories open a window into what is invisible to most people, namely that some established practices around interactive troubles in schools are ultimately exclusionary to students and parents. Each story is a unique image of how the interactions in school-family relations produce an exclusionary process. The stories are testimonies of how the interactions with the schools affect the families in various ways. The parents tell about feeling humiliated, silenced and put down. Listening to these accounts makes it possible to learn more about both exclusionary and inclusionary processes.

As highlighted in the introduction, this study aims to produce knowledge about exclusionary processes in schools with the purpose of helping school professionals to change such processes into inclusionary ones that create better conditions for helping students become somebody. If we can gain inside knowledge about how such specific kinds of experiences are created, we are better suited to develop practices that are inclusionary, diverse and supportive. It is my hope to contribute to such developments.

\section{Analysis of story 1}

Applying the analytical questions elaborated in chapter 4 will shed light on the course of events and on what was created for the participants (Foster \& Bochner, 2008). The analysis questions that are organized in three paragraphs are: 


\section{A. What are we making and how are we making this?}

1. How is the interaction contextualized by the school professional?

2. How is the problem story laid out by the school professionals?

3. How are parents' and students' voices invited, involved, valued and used by the school professionals?

4. How are parents positioned by the school professionals?

5. What options for actions are formed for the parents?

6. What are the outcomes of the exchange?

7. What are the bifurcation points in the exchanges?

\section{B. What are we becoming while making this?}

1. How is the becoming somebody of the student constituted?

\section{How can we create better social worlds?}

1. How can we do differently in responding to interactive troubles?

In the textboxes inserted in the stories you will find the answers to the analytical questions. For example, question one in paragraph A: How is the interaction contextualized by the school professionals? The answer in the textbox is; The interaction is contextualized around ... (whatever is found). This allows the reader to follow each step in the analysis process. After addressing the analytical questions, we shall see how the process affects the becoming somebody of the student. Finally I ask the questions, "What could be different? How can better social worlds be created?" So here is the first story, which is told by a mother about a student in fifth grade.

\section{Story 1}

\section{A student is silenced}

"I feared this meeting. Even though I had made an effort to try to co-create with the school manager a shared vision of the content and hopes for the outcome of the meeting, I had a feeling that they had something to bring up that they had not been quite honest about. My husband, son and I arrived at the school. Present were the school manager and three teachers. We knew that one of the teachers might attend the meeting, as we had asked for him, but it was quite surprising that all three of them were there. I looked at my son. He looked stunned. My husband had a stone face. So did the teachers. I felt crushed by the responsibility of making this a good meeting, where my son could tell his 
story and we could all co-create an appreciative inquiry into the actions that the school could initiate to help the boys, who were not getting along very well. different context than we had agreed on, my heart crimped and I felt sick.

1. Contextualizing the interaction around the student as the problem

While listening to the stream of words; "problematic", "strange behavior", "this person said...", "that person said", "your son", "blah blah...", I sweated and froze and my throat turned dry. My son raised his hand letting us all know, that he had something to say. He was ignored. The Principal kept talking. I was shocked. What were they thinking of? How could they ignore his wish to say something? I could tell by the

\section{The problem story is laid out}

into his own thoughts. One of the teachers took over and talked and talked. He lined up all the problematic actions that the boys had done, including the problematic things that our son did. I tried to find a breathing pause in his stream of words, but there was none. So I interrupted him by saying that we had come to let our son tell his story of being bullied and that he had been very patient and that I felt it would be a good thing if he could tell his story now. They all looked at my son, who then said that he had now forgotten what it was that he wished to say. The school manager quickly replied, 'If it was important, you would have remembered it, don't you think?'

Then the teacher who had already been speaking for about fifteen minutes continued. Next, one of the other teachers took over and started talking about his perspective on the problems with the boys, including our son. It was like being forced into a dark hole. My husband and I tried a couple of times to change the context and the focus of the conversation, but with not much luck.

At a certain point, the manager said, that it now was time for the adults to talk 'adult-talk', so it would be best if my son left the room. My son was very surprised, because he had not yet got to tell his story and he had not been asked any questions. and that he

\section{The situation has turned into an ultimatum 35}

I helped him to the door, whispering that it would not take long might go to the library to play or read. When I sat down again, I ashamed. I looked at the Principal. He looked me in the eyes and then said that they felt we ought to know what our son had said about us as parents. I held my breath. He continued; 'Your son says that he sleeps with you, his mom'. All turned silent...I cried, 'What? What are you saying? What?' and then broke down in tears. I said, 'Who heard my son saying that?' The manager told us that some teachers had heard some younger students talking about my son having said 
so. I asked, 'Which teachers? Which students?' He couldn't say, because he did not know. Then I asked, 'What kind of knowledge is this and for what purpose is it useful, in your eyes?' He did not answer, but stated; 'We just wanted you to know how your son behaves at school and why things have been very difficult for us'. Then, I knew that I had to take out my son from this school, and that there was no hope for continuing the collaboration.

6. The family had had no other option than to go find another school

The meeting ended, but the conversation with the principal did not. We continued the conversation through telephone and emails. In a telephone conversation the next day, I asked, while feeling very angry, 'If you consider this as solid knowledge, it must urge you to take action. Sexual abuse or sexual activity amongst family members is illegal and it is your responsibility to inform the social authorities. If you consider this as evil gossip or loose rumors, you have another problem that must urge you to take action, as I see it. Both the younger students and the teachers, and now the four of you, are engaged in telling horrible things and stories about our son and us. This confirms our experience of our son being bullied and mocked. Even by teachers spreading evil gossip. How did you expect us to react to this?' He could not answer, but agreed that they might have had misjudged the conversation.

I said that at that moment I could not make any more meaning out of this, and that the school manager and the teachers had completely lost track of professional handling, thinking and judgments. I suggested that they had just now demonstrated why my son feels so awful at school and demonstrated too how they themselves had played an important part in this situation.

He did not argue, but kept silent. I continued and said that I was most disappointed, shocked and angry - and that I expected them to investigate which teachers had told them about this, and which younger students were saying so. Secondly, I told them, that I expected the school to initiate a thorough recovery process with the group of boys, including my son, who was in conflict, and that it required a well thought through plan of action, and that the different teachers, the manager, and the school counselor unit needed to take such action.

All this was said, while crying unstoppably. Reflecting back on the meeting, I remember the female teacher being very sad and ashamed at the meeting, and she later apologized through a mutual friend for not having stopped this conversation. She had struggled to not start crying herself, our mutual friend explained to me. The main teacher, with whom we had been collaborating closely and well, was too confused by what was going on - and could not find words. The third teacher, who 70 worked as the conflict manager at the school and was also part of the student behavior counselor unit, and the principal himself stayed in the position of attack/accusation/defense, but I could tell, that they 
were not proud of the situation either and could not find any professional arguments, which only made it worse from my perspective.

On our way out, the manager had said something about not being proud of this and admitting

75 that he should have taken action months ago in terms of helping the group of boys and especially our son.

I did not accept this half-felt apology. I wanted to see actions. Later on, it came forth, that no one amongst the teachers had either heard or told 'about our son saying so', but that it was the conflict manager who had overheard and seemingly misunderstood a conversation between two of his

80 colleagues, - and based on this, had informed the school principal that, according to his understanding, this had been a serious matter.

What the two colleagues had been talking about was the language that students use and the influence that slang, and especially American slang, had on the communication amongst students. For example, 'You motherfucker', 'Your mother is a bitch and a whore', and things like that. Children at this

85 age seldom know what these words mean or how to translate them into Danish phrases. The two teachers were referring to a conversation they had overheard between a group of students, including some younger students and my son, discussing what 'You motherfucker!' means and in what contexts it made sense to use it (from a child's perspective)." 


\section{What is constructed?}

\section{Paragraph A. What are we making and how are we making it?}

Clearly some things are being constructed in these interactions. One way to understand this is to pay attention to what is made, and how is it made? Pearce (2007) states that in order to understand what our communication creates, we need to ask; what are we making and how are we making this together? Let us go through it question by question.

\section{1) How was the interaction contextualized by the school professionals?}

It took the family by surprise that there were three teachers and the school principal attending the meeting. By this the school indicated a certain seriousness to the problem, through outnumbering the family and spending the time and resources (economy/salary) on this conversation. The stone faces indicated a hostile environment and a build-up to the contextualization of the meeting, where the student was appointed as the problem. A stream of words was used such as "problematic", "strange behavior", "this person said...", "that person said...", "your son..." Numerous examples of the student's blameworthy behavior were given and substantiated.

\section{2) How was the problem story laid out by the school professionals?}

The story of the student as the problem was presented and reproduced again and again by the teachers and principal by turn-taking and in collaboration. In turns they provided examples of the student as the problem and substantiated the problem story by integrating what others were assumed to have heard and said that were supportive of their account. This happened continuously throughout the conversation.

\section{3) How were parents' and students' voices invited, involved, valued and used by the school professionals?}

Continuously both the student's and the parents' attempts to speak up, protest, and provide more nuances to the story were in various ways rejected, interrupted, denied and silenced. The boy was not allowed to speak, the teachers held the floor for several minutes and passed the speaking rights to one another, ignoring both the wishes of the parents and of the student to speak. When the boy finally was invited to speak, he had forgotten what he had wished to say and was put down. The same happened to the mother. She recalled, "My husband and I tried a couple of times to change the context 
and the focus of the conversation, but with not much luck." The boy's protest at being sent outside the room was met with silence. It was simply ignored.

Listening to this, I am reminded of the following comment by Bakhtin (1986); "For the word (and, consequently, for the human being) there is nothing more terrible than a lack of response" (p. 127).

\section{4) How were parents positioned by the school professionals?}

First, the parents were positioned as at fault for having brought up a misbehaving student. Later on they themselves were positioned as problematic; as a problem family with severe illegal relationships. Hereby, the problem was exported from the school into the home. At the beginning of the meeting, the family members were together and the parents were supportive of their son's experiences in school. When the student was asked to leave the room, the family was divided and the son was out of reach and could not contribute his perspectives. The parents were now in the line of accusation. They could no longer maintain a position as mediators between the school's story and the students' story. The mother said that the request from the principal felt like an ambush and left her with no idea about how to protest. Her agency had gone and she had felt horrible. What could have been so horrible that it could not have been said in front of all family members? Astonished as he was, her son had tried to argue to remain, but had been ignored.

Showing her willingness to cooperate, the mother helped him to the door, whispering that it would not take long and that he might go to the library to play or read. After the student left the room, she was confronted with the ultimate accusations of having a sexual relationship with her son, and broke down in tears. She managed to continue the conversation and asked some questions to which the principal did not know how to answer. The principal ended the meeting, while holding the accusations up in the air - and said; "We just wanted you to know how your son behaves at school and why things have been very difficult for us."

Despite the resistance and agency that the mother managed to perform, despite of the positioning of herself and her family, the principal maintained the accusations of the student and this time made it appear that the student was so depraved and immoral that he would say false things about his own family, just to make life for school professionals troublesome. All of this appeared to legitimize the school response and prove further the deficit behavior of the student, as claimed by the school professionals. Since the mother knew she had not had an illegal relationship with her son, she could see for herself, how her son - allegedly by saying so - must be twisted in his head in school. The school professionals had checkmated her. 


\section{5) What options for action were formed for the parents?}

The meeting ended in a hostile way. The school maintained the claim that the student was the problem and positioned itself as a victim of his disorderly behavior. In the after-play of the meeting, the exchanges between the mother and the principal developed into a dispute and a school-family-conflict. The mother demanded an investigation into the evidence of her son saying things like this. She also demanded from the school professionals some professional legitimation of the meeting, which she did not receive. In this way, she was not docile and compliant with the school's positioning of her and her family, through the silencing and devaluing of the problem story. Positioned like this, there was no worthy way for her of going on together. The collaboration had broken down.

\section{6) What were the outcomes of the exchange?}

In this case the family saw no other option than to take their son out of the school and let him start at a new one. Family trust in the school was gone. At the meeting the parents' and the student's attempts to start a conversation around how the school could help the group of boys were all denied. The family had no hope left and by protesting against the positioning of their son as the problem, and later themselves as a problem, the premise for collaboration with the school was eroded. The impression left was that the school was simply not capable of producing ideas about action to take to find solutions to what the student was telling about a problem. When the school was not capable of helping the group of boys, it was difficult for the family to see how they could let their son stay at the school. Furthermore, taking into regard how the meeting was conducted and the accusations, ignoring, silencing, devaluing them, the family saw no hope for future collaboration. The ultimatum that emerged was: either the parents complied and accepted the situation, or they would have to go find another school.

\section{Creating a spiral of exclusion}

The line of events in the interaction results in exclusion of the student, as the family sees no options for continuing the collaboration with the school, and feels forced to find another school for their child. The interactions created a spiral of exclusion as illustrated in the figure 4.1. below. In the figure the red numbers 1-6 each illustrate a moment that matters, where the school professionals acted in a certain way. 
In the story we learn there had been some interactions and planning of the meeting between the mother and the school before the actual meeting. We hear about experiences with bullying and conflicts and the family's hopes for the meeting. This is the pre-line of events leading to the parents' wish for a meeting with the school.

Figure 5.1. The Spiral of exclusion:

Pre-line of events in school... leading to the parents' wish for a meeting

The school appoints the student as the problem 1

The discussion is moved away from what the school can do to help the student. It has now become a dispute/clash of stories and a family-school conflict

The Family is positioned as problematic and unwilling to collaborate. Evidence is $\mathbf{4}$ sought to sustain the exporting of the problem into the home

\section{Exclusion as the result}

The school gives the family no other opportunity than to take out their child and find another school

\section{Moments that matter in exclusionary interactions}

The analysis can benefit from outlining the key moments that matter in the story. Key moments are critical moments, where the actions performed in profound ways establish positions and relationships. Here the trajectory for the following events is formed, building up step by step the process of exclusion. In table 5.1. these moments are inserted: 
Table 5.1. Moments that matter

\begin{tabular}{|l|l|}
\hline $\begin{array}{l}\text { Appointing the student as the problem (deficit } \\
\text { descriptions) }\end{array}$ & Identifying the culprit \\
\hline $\begin{array}{l}\text { Presenting, repeating and substantiating the } \\
\text { problem story }\end{array}$ & $\begin{array}{l}\text { Data collection -making a case - } \\
\text { accusations }\end{array}$ \\
\hline $\begin{array}{l}\text { Rejecting, denying and silencing student and } \\
\text { parent voices, wishes, perspectives }\end{array}$ & $\begin{array}{l}\text { Avoiding the inclusion of alternative } \\
\text { information (counter evidence) }\end{array}$ \\
\hline Positioning parents as problematic & $\begin{array}{l}\text { Identifying another culprit. Blaming the } \\
\text { parents. Accusations and silencing }\end{array}$ \\
\hline Exporting the problem into the family & $\begin{array}{l}\text { Explaining the origin of the problem as } \\
\text { in the family }\end{array}$ \\
\hline $\begin{array}{l}\text { Turning the situation into an ultimatum; } \\
\text { either the parents comply with the positioning } \\
\text { and problem story, or they can find another } \\
\text { school }\end{array}$ & The verdict has been set \\
\hline The family was forced to go find another school & Exportation \\
\hline Exclusion & The problem is "gone" and "done with" \\
\hline
\end{tabular}

To see the course of events as a spiral of exclusion leads to the next question concerning what we ${ }^{11}$ become, while creating such exclusionary spirals. This is highly relevant to investigate, but also a somewhat difficult task, as the story does not speak enough to this. However, becoming somebody is theoretically discussed in chapter 2 and it is not difficult to imagine how such interaction influences the self-picture of the student based on this experience.

\section{Producing deficit positions}

Paragraph B. What are we becoming while making this?

\section{How is the becoming somebody of the student constituted?}

The school professionals might had taken into account that the situation was creating a social world and shaping the identity/becoming somebody of the student in the moment. It is not only the student that becomes something or somebody, but in fact all participants are becoming somebody in the moment. There is both the becoming within the process and as a result of the process: the family becomes a problem-family, the student becomes a problem-student and the teachers and principal

\footnotetext{
${ }^{11}$ In this sentence "we" refers to school professionals, students, and parents. But it does also resonates with the becoming of the school as an institution and the broader society. However in this study, I shall be focusing on the becoming somebody of the student.
} 
become prosecutors, witnesses and judges. The student is ultimately becoming an excluded person.

On his way to exclusion, he is depicted as deviant, as a culprit, as belonging to a problem-family, and as not worthy of saying anything. Taking this into account, it is important to find ways to avoid the negative positioning. Not only would it prevent the negative and totalizing identity conclusion of the student, but it would also prevent the spiral of exclusion evolving. How could that have been done?

\section{Avoiding the spiral of exclusion}

Had the school professionals NOT positioned the student as the problem, and NOT oppressed the parents with the problem story, but listened to their perspectives, wishes and ideas instead of muting their voices, and had they involved the student and the parents in finding ways of going on together, exclusion would not had happened. Figure 4.2 illustrates such a scenario.

Figure 5.2; When exclusion is not happening:

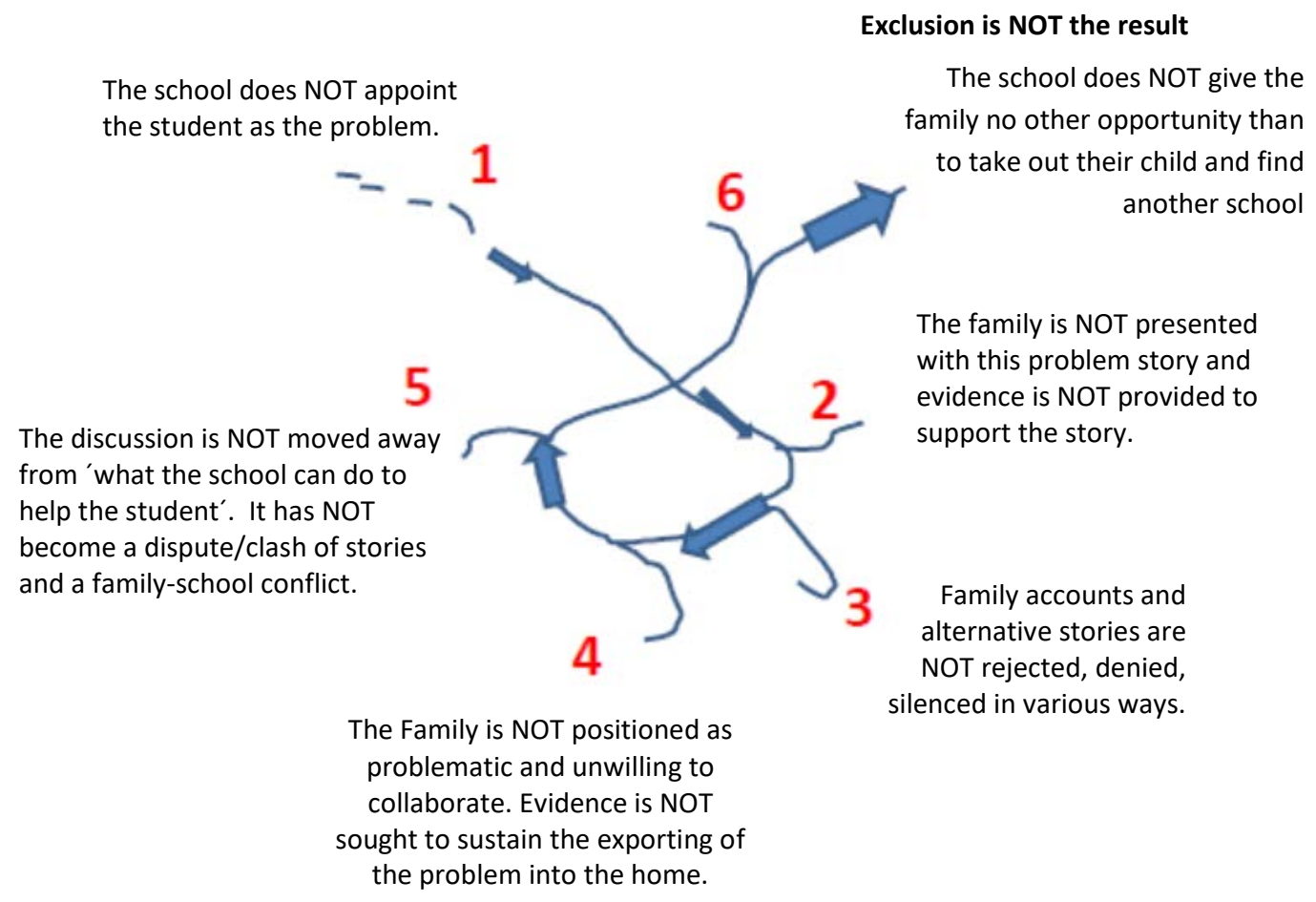


It is possible to imagine how NOT to create an exclusionary spiral. Nevertheless, exclusion was what happened. Is it a single case? Let us try to see what we can make of this by looking into further stories.

I shall now continue with the analysis. In stead of analyzing each story in detail one at a time, I will do an overall analysis of the rest of the stories. I have chosen to do it this way out of concern for the length of the chapter. As with the first story, I shall apply the analytical questions in paragraphs $A$ and $B$. Thereafter I shall summarize the findings from the overall analysis to see what pattern occurs. Finally, we will look behind the pattern to see what basic assumptions produced it. After analyzing all of the stories this way, we shall examine the question in paragraph C: How can we create better social worlds? This will further be elaborated and outlined in chapter 6 .

\section{Presenting and analyzing the rest of the stories}

The rest of the stories are different in length, form and content, however they are all images of exclusion. As you read the stories, you will also find textboxes inserted in the text. These convey the actions performed by the school professionals as they occur.

\section{Story 2}

\section{A student is made into a villain}

"When our middle son was in fourth grade, our local school was closed and all students moved to another school. This was a political decision, due to declining numbers of students in the school district. For us it meant that our three sons could no longer ride a bike to school, but had to go by bus forty minutes each way. But we were rather positive, because our sons were not the best football players, and in the old school, that was important in order to be accepted and make friends. We knew from the teachers at the old school, that our middle son had problems with his concentration, if he was not challenged the right level and he had difficulties receiving and executing common messages at the class. He did very well in math but had difficulties in reading and writing. He always did his homework, and we were working together with the teachers to see that he progressed in all topics. The receiving school had to exceed their capacity in order to receive the 65 students from the closed school. At the same time it was a merger of two different school cultures. We were introduced to the values of the new school: "A good place to be - A good place to learn". We were introduced to a system called KASA and were impressed that our sons were starting at a school where the parents would be notified with a 
letter, if their children misbehaved more than four times. Teachers didn't have to shout at the students, but would inform parents, so that we as parents should talk over the problems, and thereby make the children behave at school. All our three boys started at the new school. For the oldest of our sons it was a success. He made new friends and went from the image of a nerd to a popular guy. For our two youngest sons it was more or less a catastrophe and we have never felt so challenged in our parenthood. This is my story about our middle son.

The school started in August, and everything seemed okay. According to our son, there was almost no homework and the students spent time learning to be at class. We did not have much contact with the teachers - and it was a big surprise coming to the first parent-teacher meeting in November,

1. Appointing students as the problem. Rituals of individual blame learning that our son didn't do his homework, was annoying to the girls in the class and couldn't concentrate to work outside the classroom without teachers' guidance. We asked why we had not been informed earlier - it was four months. The teachers said they had been busy getting to know the new students. I felt very disappointed in my son and in the teachers. I remember feeling very angry, but managed to engage constructively in order to make some agreements for the future. We had high hopes and engaged actively in the school.

After a while, we learned that there was a lot of turbulence and confusion in the class. The new school worked explicitly with disciplinary approaches focused on misbehavior, while on the other hand it tried to foster student-centered teaching with responsiveness to students' perspectives. During the first year it seemed that the period of turbulence and confusion did not pass, nor develop into more static and routine condition. There were often troubles of some kind. Teasing, bullying, disrespect to teachers, noisy students in the class and so on. We experienced, that the idea of KASA and sending notes to the parents resulted in the fact that the children had no respect for the rules of the school or the teachers. The students were confronted with the threat from the teachers; "I will write a note to your parents" when they misbehaved. Our son was very confused, and often referred to some of his fellow students as holding power in the class.

It seemed like the students set the agenda in the lessons and for the behavior in the playtime. After eight months our son started every morning with a reason why he couldn't go to school today. We argued

2: Presenting and substantiating the problem story and forced him to go. By fifth grade, the atmosphere in class was kind of harsh and tough. Students did not care about the teachers' complaints. The use of disciplinary approaches had failed, it seemed. It felt like the situation had gotten out of hand. We were immensely frustrated. Later we learned other 
parents were too. Students in class had split up into gangs; the cool ones and the less cool ones and those excluded from both - and relationships between boys and girls had changed. Bullying happened in class, some teachers were "bullying" students as well. It had become 'rule by fear'. Our son had difficulties coping in that system. He was often due to his difficulties reading and writing. It

3: Rejecting, denying, and silencing parents' perspectives picked on, maybe wasn't much better with math as there became more and more text to read to solve the tasks. At the same time boys from the younger classes started picking on him at playtime. He became frustrated and with that sometimes aggressive. His frustration was met by aggression from the school, teachers and students.

We were convened to meetings to discuss what was now talked about as our son's behavior problems. We were met with awareness that he had problems with reading and writing and, according to the teachers, he just had to practice more at home. We practiced more, but it actually seemed to make him more sad, because the work led to very little progress. We knew our son struggled both in order to get acknowledgement from the teachers, but especially to get respect and appreciation from the other students, both boys and girls. When he came home from school, he was often exhausted. He had started to play football, but did not enjoy that any longer, since the conflicts continued there as well. We had asked both teachers and principal to listen to us - to try to see things from our son's perspective. Each time they nodded, but continued their focus on our son being a troublemaker.

In order to try to solve the problems in the class and the playtime our son was offered to go to the AKT, to get some time off from the problems. By this time, we started to wonder what others might think of us and our son. He was treated as the troublemaker and we felt he was more the victim, especially because the younger boys were picking on him in playtime. The school started isolating him in various ways. In winter he was not allowed to go out in the snow and the teachers had the opinion that, being the older student, he had to accept that the youngsters were not nice to him. They couldn't understand that in our opinion our son was losing face in front of his own classmates, and that he didn't have enough self-esteem to handle these situations. For our son it was loss of power every time he was picked on and he solved that by being more and more aggressive - because that was the only way he found success in avoiding being picked on.

Suddenly our son was okay about going to school - at first we were happy - until we learned, that, after a long period of not belonging in any groups at school, he now was turned into a soldier for

75 the boys in the leading gang. By acting as their soldier he no longer was picked on, and he was gaining self confidence in this new role. But it didn't last more than about two weeks before he was kicked out of the gang and now treated even worse. We were convened to a meeting at the school with teachers, 
involved students and parents - but not everybody showed up. In particular, I missed one of the gang leader students, who didn't show up. His mother declared it was because he had to practice football. I

80 was very frustrated, because I knew that the acceptance from his fellow students was more important for our son, than any acknowledgement from the teachers, which he had given up on ever achieving. If this student had participated, the boys could have talked things through and shared perspectives. The meeting felt pointless and did not change anything.

It was a period of negative relationships between us as parents and our son. Almost every day,

85 some kind of incident was reported from the school, which we had to discuss in the evening. Everything 'went back to normal', meaning that every morning started with the best reasons in the world for our son not to go to school - and days of conflict with teachers and other students, which we had to deal with in the evenings. After many discussions at the dinner table, the gang excluded him. Our son was so unhappy, because now he was the victim being picked on by even the smaller students - and we as 90 his parents did not know what to do. As parents we started talking about finding a new school for him, but at the same time we were worried, that the problem primarily was his behavior as a troublemaker and that he would continue in a new school in the same style. We felt insecure, because we knew what we had - and didn't know what a new school would bring.

Then one day about a month after the failed "anti-gang-meeting", the principal rang me at work.

95 He said that our son was sitting crying in his office, because of the fact that the previous night he had threatened two girls in the Leisure club with a knife and that the mothers had reported it to the police and the principal would like me to come to the school at once.

I have a forty minute drive to the school, so on the way I was thinking. The previous night my son had been at the Leisure club, where I had picked him up. I had talked to the pedagogue and the 100 boys and girls he had spent the evening with. The boys had told me about our son's showing a knife off, but no one mentioned anything about threats - and the girls and boys were about to buy some candy in the leisure club before going home when I left with our son.

When I arrived at the principal's office, the principal once again informed me that a couple of parents had notified the police due to an incident last night in the leisure club involving my son and a 105 knife. He could not say more than this, but a police officer was about to contact us. He proclaimed that our son was not to come to school while the police were investigating the situation and that our son couldn't go to school because the girls were afraid of him.

Together, we talked with our son about the situation and learned, that there had been a disco and that they had had a good time. He had enjoyed playing with a couple of girls and boys from the 
class, some of the gang leaders. They had played 'robbers and police and 'game of tag' and 'boys after girls'. He had been showing off with a knife - also waving the knife in the air being a tough guy. We agreed that our son should not come to school until he had been questioned by the police. Driving home, our son told me that his teacher that morning in class and in front of the others had said, that there had been a police notification on him for the knife assault last night in the Leisure club and that he 115 had to go home immediately.

Coming home I wrote on the intra-net to all the parents in the class, that we cancelled the birthday party for my son that Friday and that our son not would come to school before he had been questioned by the police.

After a week we were convened to come to the police station. We sat down around a table; my son, my husband, I and a social worker, together with a police officer trained to question children. They were very polite and approached the situation with great delicacy. My son looked firmly down the table, avoiding all kinds of eye contact. He was trembling. One officer said that two parents had called in last week to report that our son had threatened their daughters with a knife.

He didn't go into details, but asked our son to tell his story. The officer said that because our son was a minor there was no risk of punishment in the legal system. Our son told his story, the police officer said again that there was no punishment, because our son was only ten years old, so he could tell the truth without fear. Our son had nothing to add to the story. We were informed that the police wouldn't do any more about the case. They had questioned the two girls and our son, and there would be no conclusion on the matter. The officer also offered the possibility of a mediation, but in same breath he said, that none of the girls' parents wanted this. So it was really not an option. I asked if we could get copies of the girls' testimonies in order to try to understand what had happened. But that was not a possibility, because the matter never would go to court. We still wonder if the girls really felt threatened that evening at the Leisure club or it just turned into a big story, because nobody actually knew each other as parents or the other students by anything other than reputation.

After the questioning at the police station, our son only had a few days in school before they had a short school holiday. The class had spent a lot of time talking about what now was known as "the knife assault" in the class and the entire school. Everybody seemed to have talked about our son, while he was absent - and now there was no doubt in the teachers', the students' or other exported into the home/family parents' heads that our son was a bully. 
We felt our son was 'convicted by the public', by the other parents, the teachers and other students. Nobody asked how our son had experienced that evening playing in the leisure club. He wasn't allowed back to school for the rest of that week. The school had sent him home "to think about it". Meanwhile the gossip grew and the story spread. Our son was not feeling very well at home, anxious, missing his mates at school. He didn't really want to go to school, but staying at home was not helpful.

A week after he had started back at school, I rang the parents of the girls. I was very frustrated and I wondered why they hadn't called us, the night of the "knife assault". I had a really good talk with one of the mothers, but the other mum was not very nice. She couldn't understand how I could have

150 left the children that day in the Leisure club knowing what my son had done. She wouldn't accept my explanation that it was because I didn't know about it, neither did the pedagogue at the club - I told her that I had talked to the girls and the boys briefly, when they were on their way to buy candy.

I talked to the school about having a meeting with the girls and their parents, but none of the girls' parents were interested in such a meeting. The school then arranged a meeting between the 155 children, and I think the meeting was okay. The situation between the three children seemed to normalize.

Shortly after, I got a real nice email from a mum of one of the other students in class. She wrote that she was thinking about us, and that it was a difficult situation for our son coming back into the class and that they had talked about it at home. This was very comforting. Then she and yet another parent arranged a meeting at the school trying to start some sort of positive cooperation among the parents. It was a good meeting with good intentions from the parents and the school. But in my opinion the school never managed to do what they promised at that meeting. And the meeting confirmed that the school might have tried to make the students get along, but they had done nothing to build relationships amongst the group of parents. Now we only knew the other students and the teachers by the rumors

165 from own children. Actually I found myself in a group discussion with one of the girls' mothers (the positive one) - but it took some time before we realized, that we actually were sitting next to each other agreeing on most things about to how to make a better class for our children. We didn't know who each other was. That day it was a little awkward, but about six months later, when our son had changed to another school I ran into her and she said that had she known us on the day of the episode with the 170 knife, she would have called upon us first. She didn't know if she still would have called the police, but she would have wanted to meet, because the children should have had a chance to talk it through. At the time of the parent meeting at the school, I was very focused on our problems, but at the meeting I 
learned, that the class was rather dysfunctional. The teachers seemed to have lost power over the students. It was a difficult meeting, because the girls' story seemed to be the truth in the general opinion - and it was difficult not to feel ashamed.

It was a sad time for us as a family, with a lot of talking late in the night when the children were at sleep. We were worried and we experienced, that the school had a lot of good intentions but never met the intentions with actions. It was like they didn't believe, that we had no problems at home with our sons' behavior. So they almost convinced us, that it was because we didn't have any requirements for his behavior at home that he didn't know how to act in school. We talked a lot with our family, which includes a children's psychologist and several teachers. This was where we found support for believing that we were good parents with a sweet boy. That was how they knew our family. It was extremely hard emotionally and we doubted our own skills as parents. I learned about Ross W. Greene and the explosive child and we started questioning the way the school handled our son.

In December one day the boys in the class and the boy my son admired the most pulled him out on the playground, where there was lots of snow, "washed" him with snow and held him to let the smaller students put snow on him. When he got up he exploded, ran into the school and slammed the door and threw a chair. He ran after two of the smaller students who had put snow on him. The two students locked themselves in a restroom. A teacher came and he afterwards said that he had to hold our son to calm him down. We were convened to come to the school for a meeting with the principal and the teacher. They told us that other parents had complained about our son, that it was a small school and they couldn't afford to lose children to other schools.

Our son was no longer welcome in class. He could have lessons by himself, home education or we could consider finding another school. Not that they as professionals could recommend changing 195 schools because the misbehavior would probably continue.

All our son wanted was to be accepted. I could see him choosing wrong strategies all the time trying to get popular and no-one was making the effort to help him find his way in school. He really wanted to be with the other students. So we had no doubt about changing school, he should have a new chance - if he

\section{The situation had turned into a family- school conflict}

200 failed that, we had to look for alternatives.

\section{The family had had no other option than to go find another school}

Now, we just regret that we didn't change schools much earlier. Because of the troubles in the old school, the receiving school maintained a focus on structure, his difficulties with common

messages and testing him. We learned that he is dyslexic. As parents it hurts when you realize, that we 
205 held our son for $1 \frac{1}{2}$ years in misery going to a school which actually wasn't professional enough to meet his social and professional needs. Sometimes I think that if the episode with the knife had not happened, he probably would have spent $1 \frac{1}{2}$ more years in that school, because of our belief in the professional teachers and the principal. Today we suffer from our experiences. Teachers and other professionals around our children are no longer met with confidence. We once experienced failure and

210 now we have trouble feeling confidence in the school system. We know it is emotional - but I sometimes wonder when we will feel confident again. Actually I still feel very angry when I think back. I still can't talk about our experiences without crying with anger. Today I still feel anger, but I am not ashamed any more. We live in the same local area and sometimes people ask why our children changed schools. The short answer is - you have to find a school where the pedagogy matches your children's 215 needs. And if they are more curious I gladly tell our story, spelling out that it is our story". 


\section{What was constructed?}

This second story is slightly different from the first one but depicts the same steps in the exclusionary spiral and results in the final exclusion of the family. The first step in the exclusion is to contextualize the interaction around the student as the problem. Next is to present, repeat and substantiate the problem story, which was done whenever issues of interactive trouble occurred. Hereby a thin description is taking form, where the description of the boy narrowed down to very little nuances. Thirdly, the student's perspectives were not involved, invited, or valued, neither were the parents'. The mother's attempts to find ways for her son to thrive in school was met with ignoring. Had the school professionals invited the student and the parents into the conversation in a different way, and had they listened to the student's accounts, they might had made room for a more nuanced and thicker description leaving more options for co-creating a desired future. But they do not and this is the fourth step. By the repeated assertion of the student as the problem, the parents are accused of being responsible for the situation, and over time, the parents are positioned as difficult and as responsible for fixing the problem at home, which is step five. This is seen in the school's request of the parents to train their son at home, which they tirelessly toil on with, only to much later realize that he is dyslexic and that their training was futile, if not contradictory. It is also seen in the continuous complaints about the student, the numerous requests for the family to meet at the school, and to come and pick up the son after issues of conflict. As the problem is located within the boy and the family, in combination with avoiding finding solutions and resolutions in the school, both the responsibility for the problem and for finding solutions was exported into the family. Configured and isolated as the family's problem, the situation turned into an ultimatum with very few options for the parents. The exclusionary process resulted in the final ultimatum from the school: either the parents accept home-teaching or they find another school. This is the last step in the spiral. To accept home-teaching would be to accept the problem story and comply in the face of the worldview of the school, including the positioning of their son and the isolation of him at home with very poor perspectives for his future life. The other option is ultimately to find another school. Since there was not really a choice here, the family finds another school for their child. Thereby the exclusion of the student and his parents is manifest.

Each of the steps in the spiral represents a moment that matters, which is to say that one by one they move the family closer to exclusion. However, each moment that matters is also a choice made by the school professionals, and could have been different. Had the school professionals chosen to do differently, the exclusion, stigmatizing and devaluation of this family might have been avoided. Had they engaged in appreciative inquiry of different perspectives, involving the voices of the family in an 
effort to strengthen the relationships in order to develop worthy positions for all students in school, this family might had been spared years of suffering in struggling for dignity in relation to interactive troubles at school.

\section{Story 3}

A family becomes insignificant

"My husband and I divorced some years ago and I remarried and had a second child. At that time my son changed school too, because I moved. He started in a good class with a lot of nice students and families. He quickly made friends and became part of the community. The first year went well with relatively stable teachers. Whenever the class had a substitute teacher though, it became out of control. Some parents from the class wrote both to the teachers about this problem, and later to the AKT-teachers and the principal. We always got the same reply. They were aware and would do their best. The following year the class was upgraded to intermediate and all the teachers were shifted. The group of parents wrote to the principal to urge her to connect the class with stable and experienced teachers. She replied that she would take it into account. Unfortunately we got the one teacher with the worst reputation and the most teacher absences of all. The other teachers began to have a lot of absences, too. One teacher took an extra part-time job at the museum and traveled a lot with this job. Another teacher got pregnant and had many sick days. A third teacher went to a lot of courses and had other duties at school, so the class often had substitute teachers with no teacher training - mainly young students

3: Rejecting, denying or silencing parents' perspectives

15 from college. Within a short period of time it was chaos in the class. Noisy, unfocused, with a lot of yelling and tossing around. Many parents complained. Students were sad and frustrated with "those who destroyed the lessons". Stories started to spread. It was his and her fault, and so on. It was unbearable. My son took part in it all, but was at the same time very tired after school and complained about headaches. I kept informing the teachers and the principal. A group of parents met a couple of

20 times to talk about what could be done. Some each other through the internet. It appeared that it was a couple of the boys who were the cause of the

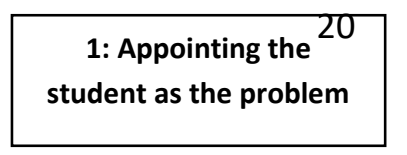
parents wrote to many agreed that problems.

\begin{tabular}{l|c|} 
Those & $\begin{array}{c}\text { 4: Positioning the family as } \\
\text { problematic - the problem is } \\
\text { exported into the home/family }\end{array}$ \\
One parent &
\end{tabular}

parents that raised the question about teacher under qualified substitute teachers were mocked. suggested that all parents should meet at school 
and in small groups talk it through. Who had heard what? What did the students tell them at home? Which of the students was to blame for all this? And so on.

He believed that when parents realized how terribly their children behaved at school they would make them change. First a couple of parents agreed to come to such a meeting. Then one couple wrote that they felt that both teachers, AKT-teachers and the principal should attend such a meeting. They also asked questions about who would facilitate such a meeting. Then other parents wrote that they now felt that it would be better if the school invited all parents to such a meeting and that they facilitated it. Others wrote that it would be dangerous and stupid to believe that only a couple of students were to blame - it was the whole culture of the class that had developed in a wrong manner. During this process of writing back and forth, the situation in the class intensified. Conflicts among students increased as well as conflicts between teachers and students. One day we got the message that a boy - a leading positive figure - was moving to another school. His parents could not handle the negative positioning of their child. After having tried everything, they moved him to another school.

We - the group of parents - wrote to the principal informing her about the intensifying of the situation and asking once again for a meeting. This request was denied. The situation was being taken care of, she said. Then we gave up. My ex-husband and I agreed that it should end. Our son had been miserable for months and not learning anything at all. We knew that there would come a permanent replacement would conduct other teachers

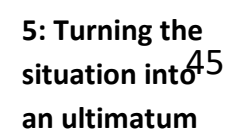

for the pregnant teacher, but we did not know who or if $s /$ he teaching on a more stable basis. We did know though that the were to take care of the class for the next three years. Therefore we doubted that the situation would be any better.

After trying for months to engage in a conversation with the school and forewarning about this situation, we gave up. We couldn't stand our son being so sad about going to school every morning. We couldn't stand

6. A family is forced to find another school not being listened to, just being ignored. We know from other parents, that after moving our son, things haven't changed. There are still problems of noise, unrest, a lot of scolding and yelling. We are happy that our son is no longer part of that learning environment" 


\section{What was constructed?}

The interaction evolved slightly differently in this story than in the previous two, however it ended up similarly, namely in the exclusion of the student and his parents. First, the parents' accounts of the problem was rejected and denied by the school. The school avoided responding responsibly and refused to take action, which left the parents and their request devalued and diminished. Meanwhile, the parents we witnessing an increase of the problematic situation in class, and the spreading of the conflict into the larger group of parents. Students were suffering on a daily basis and parents' frustration increased as well. The school consistently rejected the numerous attempts of the parents to engage in collaboration, and consequently the school ended up "allowing" the rise of the individual blame on a couple of students as the problem. As a result, the school missed the opportunity to avoid the development of the exclusionary process. Even though the parents asked for help several times, the school refused to listen and to take responsibility for what happened in class. Thus, voices of parents and students were not listened to, involved, or valued, but instead were silenced in various ways. Continuously being rejected and silenced, the parents that were asking for help, were positioned as insignificant and problematic. Left alone with the problem and with finding ways to solve the problem, the problem was exported into the homes, as well as the responsibility for solving it.

The dialogue that the parents wished to engage the school in concerned what the school can do to help the students, but the school refused to have this conversation. As advocates for the children, parents are eager to engage to improve school life for their children. If no one else seems to care, the eagerness might turn into a stronger emotion of obligations, outrage and despair. Had the parents experienced some kind of commitment from the school, school and families might have united in the shared obligation to offer safe and constructive learning environments for the students, instead of becoming divided. On the contrary, the destructive learning environment continued as do the conflicts among the group of parents about who to blame. Since the school was not willing to collaborate, the group of parents were left alone to deal with the problem, but in reality with only very few options for action. Appointing and blaming single individuals among the group of students foiled the exclusionary spiral. Since there was no help from the school professionals, the parents lost hope for any improvement in the situation and found no other option than to move their child. The exclusionary spiral had come to an end. Thus, there were not many options for action provided for the parents. They could not make changes in the classroom, neither in regard to teacher absence nor in relation to the attitude of the school. The interaction turned into an ultimatum for the parents; either they could become docile in the face of the school's worldview, which meant to accept the refusal to collaborate 
and the continuation of the situation in the class. Or ultimately the family could find another school. Since both the hope for improving the teaching environment in class and for collaboration with the school was extinguished, the family is forced to find another school. The exclusionary process had come to an end.

What could have been different? Had the school listened to the parents' requests and taken responsibility for the situation in class, the collaboration might have developed into a

shared understanding and the co-creating of a better school day for the children. It might require the school to be willing to provide more stable and qualified teaching. Both students and teachers would benefit from an improved learning environment. The worry and frustration among the parents would have eased and left space for reassurance and confidence. The two boys appointed as the problem would have been spared this experience. Considering how being appointed as the problem, blamed and stigmatized exerts an influence on self-perception, on friendship, on learning and on the process of becoming somebody, this would have achieved the biggest gain from a different course of events. Furthermore, engaging in collaboration with parents might have paved the way for co-creating various ideas of how to solve the problem. Avoiding rituals of individual blame and focusing on relationships, structures and culture both emphasizes and requires professional responsibility. Herein lies an opportunity to develop inclusionary practices focusing on the higher purpose of education. Through engagement in collaboration with the parents, the school might learn various things about life in school. At the same time it would have been honoring students and parents, making them feel important and worthwhile, which would have been a first step in strengthening the belonging and developing of a constructive respectful relationship. Consequently, exclusion would not have been the result, but instead ways of being and ways of dealing with interactive troubles (ways of being in relation) would had been modelled for all involved to learn from.

\section{Story 4}

\section{When a girl becomes invisible in school}

"Our daughter, Lea, has had 4 good years at this school. She had really been happy and was enjoying school. No doubt about that. The problems began just before Christmas. One of the girls, Sofia - who has always been hanging out with Ida - suddenly became best friends with Vigga, who had been our daughter's best friend for a very long time. The dynamics of the friendships changed. Of course both Ida and our daughter Lea became very unhappy and heartbroken about being left and rejected. But our daughter is the kind of person who acts in such situations. She felt that this was not 
okay and that this was not the way to treat each other. So she told this to both Sofia and Vigga. They reacted by not wanting to talk with her. They turned her down and stopped communicating with her and ignored her. It seemed that the teachers did not really care.

Quite quickly we found out at home that Lea was miserable in school. She did not want to go to school. Every morning we had the same quarrels about going to school. By February we realized how serious the situation was. Lea told us a lot of things going on in school. The situation had become worse, since more students in the class had started to ignore her as well. She felt very isolated and lonely and afraid in school. Ida was trying to hang out with Sofia and Vigga hoping to be the third wheel in the wagon. There was no one left for Lea to hang out with. Unpleasant episodes of ignoring, rejecting, nagging and teasing Lea had become everyday life.

Things just escalated, and more children took part in it. The teacher had discovered the problems amongst the four girls and asked them to come to a couple of meetings. At the first meeting, Lea was asked to tell about what was going on, and she did. This made two of the other girls feel so miserable, that they started crying. The teacher and the girls met like this four or five times, but with no results or changes. I am not quite informed about how the teacher facilitated the meetings. I guess he was just talking with them, but it did not help. In the Leisure Club, the professionals were concerned as well and also tried to talk with the girls. This changed things a bit for a while. They gathered a group of twelve girls all involved in it. This resulted in a stronger focus amongst the girls and a shared understanding of all being affected by the conflict. Some of the girls were nicer to Lea for a couple of weeks.

During April the teacher sent out a letter to all parents in the class. He does that twice a year or so. The letter said that the learning progress in class was good and that things socially were good too. My wife wrote him back in order to make him understand, that things were not good amongst the girls and that our daughter was suffering from neglect and exclusion. She added the parents of Vigga, who used to be our daughter's best friend, as addressees on the letter. We used to have a good connection with them. They wrote us back that they agreed and they asked for a third professional to help resolve the problems. Then something happened. The school and the teacher suggested that a school psychologist was invited. The teacher informed the parents of the four girls about this decision. An 35 action plan was made, so the girls and the psychologist were to meet twice during two months. Only the four girls and no one else.

I then decided to write to the school to let them know that this was not clever or acceptable. Firstly, because many other students were involved and secondly, because the timeframe was too 
longitudinal. We needed help immediately. Our daughter could not wait that long. She was miserable, unhappy, and most days she was not going to school at all. The teacher never responded

3: Rejecting, denying and silencing parents' perspectives to my email. For several weeks our daughter stayed at home. In these periods she visited her grandmother, who lives next door. We argued every morning about it, but often we could not make her go to school.

Then an email from the school ticked in. The principal wrote us because he had heard that I had

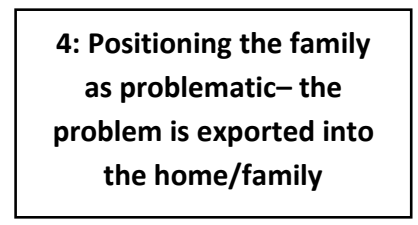
been talking critically about the teacher, so he wished us to come to a meeting with him and the teacher. I never intended to criticize the teacher. It wasn't meant like that, but he must have felt it like that. The principal wrote that he had asked the teacher not to have any

contact with us. In the letter he convened us to come on a certain date and time, which was during daytime, when both my wife and I were at work. We are both managers with big responsibilities. It was not formulated as a request or a question about when it would suit us. It is a matter of great seriousness to be convened to show up like that. It is a signal. Probably they want us to move our daughter to another school, I remember thinking.

I wrote him back, that unfortunately we could not come at that time of day, because of our work, but that we would be happy to meet at another time. Then we got a new request to meet a new date and time, also during daytime. We knew we had to end that game. So we called in sick at work and asked the chairman of the school board to join the meeting, which he did. The chairman had some legitimate power over the principal. It had happened before, when serious conversations needed to take place amongst parents and the school, that the parents had asked the chairman or another member of the board to join. So the meeting was set up for the principal, the vice-principal, the teacher, the chairman, my wife and I. All came but the vice-principal. The meeting went well, I suppose. The teacher told a long story about what had happened. My wife interrupted him and said that she felt we should look ahead and not at the past, and it would be better to talk about what could be done to help the girls. We did not have that much time, only an hour or so. We said we had a great confidence in the teacher and looked forward to cooperating with the school psychologist. It went well.

Since then we have had a meeting with the school psychologist, just the three of us as a family. It was on our initiative and it was a great meeting. We met at the municipality office and not at school. She talked to our daughter and asked her questions. Lea talked and talked. Then the psychologist concluded that this was a typical example of bullying. She would like to help, but often such problems 
are not fixable. So she suggested that we started looking for another school. She really understood how horrible the situation was for Lea and us. This was the first time anybody had used the word bullying. We were very happy for this labeling. Lea understood that here was an adult who had listened to her and understood her. We cannot explain what a wonderful feeling this was for us. She said several times to our daughter, that she needed to know, that she really wanted to help her. But that it was not always working out in good ways. Therefore you need to start looking for another school, too. If this intervention that she had in mind, did not work out, the only thing left, was to move to another school.

Lea was very happy, "The psychologist wanted to help me. And if she cannot, I can always start at another school." The next step was that the psychologist would meet with the four girls a couple of times and then with the whole group of students. She would also come to visit the class during teaching and meet with teachers to establish a process. It was fantastic. We were all very relieved and hopeful about the future. But after that, nothing happened. Well, she met twice with the four girls and that was it. The school stopped the intervention without letting us know. Nothing changed and nothing happened. So we started to look for other schools.

There were no signs of things getting better. No other children were ever involved and no other parents. Nothing. No information from the teacher. No information from the school. We kept sending mails to the teacher telling him how miserable Lea still was. About how she again and again stayed at home: "She won't be coming today"; "Unfortunately she will stay at home to day too", "Today she left school early", and so on. The teacher never answered these mails. But he was informed continuously. It seems to us that the school professionals think they have done as much as possible. They had held a meeting with us. They had invited the psychologist and she had had two meetings with the girls. Apparently the school professionals think this is what can be done. The dialogue that we have tried to establish with the school has not succeeded except for that one meeting that we were convened to. In the perspective of the school, this was about a conflict amongst four girls. But we think this has to do with the whole class. The school will not talk with us about this.

We have lost confidence in the school. We no longer believe get better. The school did try to help, but never understood the

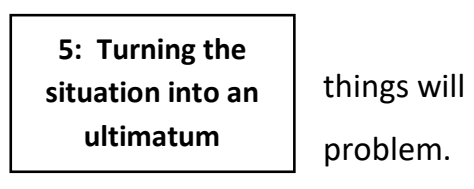
So Lea is starting at a new school after the summer holiday. We sent a formal withdrawal and goodbye letter to the school.

100 students in class intranet. We also Afterwards we informed the teacher. Then Lea told the and the same day we wrote to all the parents through the mentioned what school Lea would be moving to. Within a week, three other students from the class were moved to the same school we moved to - two girls and 
one boy who had not been directly involved in the conflict. It turned out, though, that they too had suffered. We did not know about this during the process, since none of the parents had contacted us. They had decided for themselves.

The teacher first wrote to all the parents (including us on a standard list of addresses), that our daughter would start at a new school. Later he wrote again to all parents that a couple of students would visit another school, and later again, that they would move to the other school. He also commented that he was saddened about this. The last day before holiday the students had breakfast in 110 class. It went alright. Lea had the chance to say goodbye in some way, but it was difficult. We had told her that she needed to come to school also the last few days. We told her, that she would regret it, if she didn't get to say goodbye. So she did.

Now it has all ended. The rest of the class will start over again after summer holiday and I fear that things will continue to turn out to be problematic. How long will it take until new conflicts and 115 bullying happens? This is so saddening and frustrating.

The group of parents of the four girls in conflict had tried to talk it over. We had all been in dialogue, but we had very different understandings of the situation. Every parent took the perspective of their own child and felt that their own child had tried enough to solve the issue. We were very far from looking at things in the same way. We simply could not handle how to create a good dialogue. We tried, but our perspectives clashed. 


\section{What was constructed?}

Similarly to the previous story, the interaction in this account was contextualized first around denying and rejecting the problem, then around appointing the student and the family as the problem, which finally led to the collaboration breaking down. For the family it was very difficult to get any help or understanding from the school professionals. Somehow the school professionals evaded taking responsibility for the student's experiences of being excluded from her friends. Due to the pressure of the family some initiatives were tried out, but according to the family, sound investments were never carried out. The girl and her family were left by themselves to cope with the problems. The experience with bullying and exclusion was not accepted as valid by the school at first, and their neglect and refusal to act, left room for the bullying to worsen. As such, the problem grew in the absence of professional responsibility. Initially students' and parents' voices were rejected, denied and silenced.

Later on, however reluctantly, parents' and students' voices were given a restricted place and only on the premises of the school. This was seen in the convening of meetings without paying attention to the parents' obligations at work, which the parents perceived as devaluing and reckless. Furthermore many of the parents' attempts to get into dialogue with the school professionals were not accepted, and when communication did take place, the parties talked past each other. The parents did not feel understood or listened too, but found themselves positioned as problematic and demanding. The school's denial of the problems among the students left the parents and the student(s) alone with the problem, resulting in the exportation of the problem into the home, which gave very few options for action for the family (as well as the school). The situation turned into an ultimatum where the parents either accepted the way things were and became docile in the face of the school's worldview, or they could find another school. The outcome of the process was that the family saw no other option than to move their child. The exclusionary process resulted in exclusion.

However, as in the other stories, things might have developed differently. Had the school listened to and acknowledged the experiences of the family around bullying and exclusion by the classmates, and had they known of methods to work successfully with these relationships, the school might have solved the situation. Had the teacher accepted the experiences of the student and acknowledged the family's wishes to find ways to improve the social life in school for their daughter, the collaboration might not have broken down. Initiating the work of restoring relationships and developing friendly ways of interacting in class, the school might have created inclusionary processes instead. Such Initiatives that develop relationships and create inclusionary processes would have offered the girl much 
better experiences and spared everyone the negative process of separation, stigmatization and ultimately exclusion.

\section{Story 5}

\section{A student is excluded by a teacher}

"Our son had been a student in this class for four years. He had known many of the other kids since kindergarten. Personally, my husband and I were friends with other parents in the class and knew some teachers privately, too. We felt very secure and satisfied with the whole thing. Our son had many friends in class and was very active in his spare time and with leisure activities. A group of students was very energized and active both during recess and lessons. Our son was one of those students. In times of teacher absence, temporary workers who were not trained teachers led the classes, and the students did not behave well. Unrest, fuss, noise and banter made the teaching situation severe. When teachers came back from absence, they had a hard time to re-establish a good learning environment. Both other parents and teachers wrote back and forth about this through the intranet. Some other parents were very unhappy about the situation and complained that their children were suffering. Our son complained too, but was overall happy about school. Then we started receiving messages from the teachers about our son being difficult and noisy in school. We listened and talked it through with our son each time.

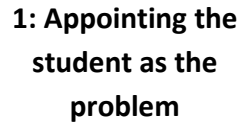
this to the teacher. He responded with further argumentation and accusations.

This seemed to go on for a while and continued for several months - only to intensify each time. For us this request that

\section{2: Presenting and substantiating the problem story}

was most unpleasant and humiliating. We made the deepest the teacher would take note of our son's experiences and

perspectives. We pleaded for responsiveness to our situation and gave thousands of examples of groups of students engaging in and contributing to behavior patterns that were counterproductive from the teacher's perspective. We were met with silence as the teacher only focused on our

3: Rejecting, denying, or silencing parents' perspectives

25 son's guilt and faults. Our trust in the teacher and the school slowly eroded. We contacted the AKTcounselors for help. They replied that they could not engage or intervene without permission and funding from the principal. So we contacted the principal in order to inform him about the situation and asked for leadership support and help to get the class to work again. We got the reply that we should 
cooperate with the teacher. If we were not satisfied with this, we could lodge a complaint. It was a dead end.

We tried formally and privately to talk with the teacher and some other parents in the class.

Other parents were worried as

that our

the

5: Turning the
situation into an
ultimatum

35 difficulties sleeping at night and my husband had begun to get a stomachache. It later developed into incipient ulcers. We both felt enormously troubled and could see how this affected our son too. He withered and lost his zest for life. He told us

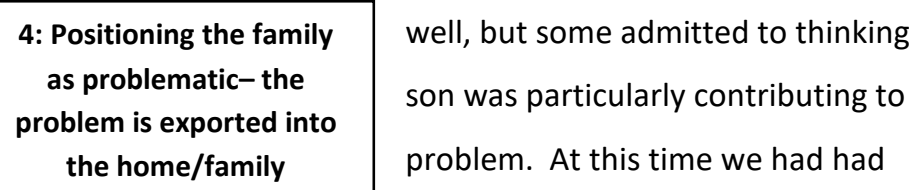
well, but some admitted to thinking son was particularly contributing to problem. At this time we had had about constant scolding, reprimands, reminders in school. He felt humiliated and unfairly treated on a daily basis. This affected not only us as parents in terms of low energy and reduced working ability, but also his two little brothers were affected by the whole situation. We had come to a point, where we felt too horrible about sending him to school. We couldn't go on any longer. I then asked my leader - I am a teacher at another school - if I could take my son to work for a period of time. During the process I had involved my principal in the situation both for support and coaching and in order for me to get leave of absence when the situation needed it. We arranged that our son could start as a student at my

45 school the day after. We informed his teachers and the principal at the old school as well as the parents. The next day I went with him to school in order to support him in telling his friends and to say goodbye. He was very happy that it would now all end and that we finally had found a solution. But at the same time he was very sad and unhappy to leave his close friends and anxious and nervous about telling them and saying goodbye." 


\section{What was constructed?}

The interaction between the family and the teacher was contextualized around the teacher appointing the student as the problem. The teacher presented, repeated and substantiated the problem story on a daily basis. Parents' and student's voices were not involved, integrated, or valued, but rejected and silenced. The parents were positioned as problematic and as not willing to solve the problem (fix their son), and the responsibility for fixing the problem was exported into the family. The situation offered not many options for action for the parents, but turned into an ultimatum. Either they accepted the positioning of their son as causing the troubles in class, as well as the repeated teacher absence along with the school's refusal to improve the situation, or they could find another school. It was not really a choice, since the situation was unbearable for the family.

How could things have been different? Had the teacher understood the problem not as being caused by one student, but as relational and interactional, he might have seen how his own understandings, communication and ways of relating, were part of the problem. Had he continued following on these lines, he could have engaged students in co-creating an easy, fun and trusting learning environment in class, where all contributed as co-responsible members. Had he listened to the parents and the student, and acknowledged their resources and aspirations, he might have avoided the rituals of individual blame, which here were repeated in the appointing of the student as the problem, the stigmatizing of him and finally the exclusion of him. Had the teacher worked to develop relationships, sharing thoughts and hopes for the future, strengthening curiosity for learning, and working with friendships in class, which were all possible actions to take, the situation might have been handled successfully and in an inclusionary way. This would have prevented the student from suffering in school, as well as the family's sufferings at home. Avoiding scolding, negative positioning, reprimands and so on would have benefited all students in class as well as improved the learning environment. Instead what was repeated again and again was the repetition of individual blame, which was a certain way of being and of being in relation that was modelled over and over. Both the teacher, the student and the parents were trapped in a spiral of stigmatization and exclusion, and it was very difficult for the parents to see how they could escape it. 
Story 6

When a student is persecuted

"This is our oldest daughter and she was in seventh grade when it started. She had always been a smart and pretty girl in school, liked by many and with good grades, but also the quiet type. $\ln 7^{\text {th }}$ grade she started to make friends with some older students. One boy became her boyfriend. He was nice to her and was really popular. He had many friends, both boys and girls, and they became friends with our daughter. As time passed, she spent more and more time with them and less time with her own classmates. In the beginning it was alright, but then she started feeling excluded. They were nagging her, whispering behind her back, rolling eyes at her and that kind of thing. In lessons she worked alone, when everyone else worked in groups. It was becoming really problematic and unpleasant for her. She lost her happy-go-lucky attitude and started acting weirdly - depressed and angry and self-destructive. We kept contacting the school, and each time they replied that they were taking care of it. The nagging spread so that even the friends of her boyfriend started treating her badly. They send her nasty text messages. She began to avoid spending time with anybody else but her boyfriend. But even their relationship was suffering. He wanted them all to be friends. More students were engaged in writing negative and aggressive things about our daughter and now it was

\begin{tabular}{|c|}
\hline 3: Rejecting, \\
denying, or \\
silencing parents' \\
perspectives \\
\hline
\end{tabular}
not only text messages on her phone, but all social media.

One day she showed us a Facebook thread, where students threatened to kill her and wished her dead. We rang the principal and informed him about how the situation was unbearable and that our 20 daughter would not come to school any more. He understood and apologized that they had not taken it seriously enough and that it had now gotten out of hand. He would take action now - contacting the students involved and their parents and perhaps the police as well. But it was too late for us. We no longer believed in the school's capability of responding and our daughter was frightened and scared to go to school. She could not go anywhere, she said. Students from neighboring schools had been writing send our 5: Turning the 25 situation into an ultimatum too, threatening to attack her downtown. The only option was to daughter away. We arranged for her to start at a school at the

other end of the country, where she could live at my brother's place. He is married and has three children and they would love their older cousin

6. The family is forced to go find another school to come live with them for a while. She stayed there until the summer holiday and started a boarding school the following semester. She is very happy there and the personal persecution has finally stopped." 


\section{What was constructed?}

The interaction between the school and the family was contextualized around 'not taking the problem seriously', and thereby not taking the situation for the student and the family seriously. The family insisted on asking, demanding and requiring the school to take action. The school met the family's requests with not much response, which caused a new problem for the school, namely how to avoid engaging with 'the demanding family'. The story did not say much about how the school understood the problem, but by refusing to respond, they left the family alone with the situation, which made it possible for the problem to increase and spread into a larger network of students. By not responding, the responsibility for solving the problem was exported to the parents. Parents' and student's voices and perspectives were not listened to, responded to, or valued. The school professionals avoided engaging in collaboration and did not take effective action in school, either. As a consequence of this the student's wellbeing was not cared for, but met with ignorance. The parents were positioned as not worth listening to and collaborating with. They were rejected, denied, and silenced, which left them with the feeling of not having many options for action. The situation turned into an ultimatum; either the parents accepted the situation or ultimately they could find another school. Since the situation was unacceptable, the process resulted in the student's final exclusion not only from the school, but from the local and regional community. Life for the girl had become so unsafe, that the family saw no other option than to let her move in with her uncle in another part of the country.

How could this exclusion have been avoided? How might things have developed differently? There are a couple of things to take into account. Had the school professionals acted constructively and responsibly right at the start, when the family had asked for help, a process amongst the students concerning relationships, friendship, tolerance and the like could have been initiated. Perhaps such a process could have involved parents as well. Importantly, at this stage, only a few students were involved, and as such the advantage of solving the trouble while still small would have been gained. As a side effect, the family would have felt granted respect and listened to and their daughter would have been spared severe bullying incidents and fear of going to school, and eventually of going anywhere. However, it is likely that something came before the bullying occurred. This 'something' may have been shown in the communication or in the relationships among the students, and the school professionals might have acted at this point by strengthening the relationships and emphasizing the importance of friendly behavior. So the question is, how might the school have prevented the bullying pattern from 
occurring? The next question is, what might have been the options for the school when they discovered that bullying of the girl had taken place?

\section{Story 7}

\section{A student becomes the scapegoat}

"Our son had been a student at that school for four years - since kindergarten. His younger sister was a student there as well. He had had some good years overall, I suppose, both in regard to the other students and the teachers but then things started to go wrong. Conflicts amongst the students had emerged, which made parents dissatisfied. Teachers started complaining about noisy students who were not concentrating during class and some bullying events. Sometimes our son was mentioned - as well as other

1: Appointing the students as the problem students. We took it seriously from the beginning. Our son had complained as well and was saddened about the situation. He often came home from school tired and in a poor shape. We had conversations with both teachers and the AKT-counselor together with the vice-principal and the principal. They had tried some disciplinary approaches, where a student that misbehaved, would receive first three warnings given as crosses in a protocol, and if this did not work, then the student would be sent to AKT (Office for student misbehavior) or into another class to attend lessons there for a while. If this did not lead to better behavior when the student came back into class, the student would be sent home for a week 'to think about it'. It seemed that this approach had only made things worse. The misbehavior and the noise and lack of concentration had increased. Some parents began writing to each other and the school through the intranet. Some were really angry and accused others about the situation. Students, parents and teachers were attacked by name. The situation intensified. We got more and more worried, since our son's name kept appearing in the other parents' writings. We wrote too and tried to explain that our son suffered as well and that we wished to find ways to better the situation for all. Then the principal and vice-principal invited all parents and teachers to a meeting, where everybody was invited to share thoughts and hopes for the future. We came too in hope of a good meeting, where we as a group could co-create some solutions to this misery

The meeting started off in a depressed mood. The seriousness was painted on people's faces. The vice-principal started by explaining the reasons why they had invited all to this meeting. The conversation took off when some parents aggressively complained and attacked the school for allowing one student to ruin it all for the rest. Other parents nodded to support this utterance. We did not at that point realize that they were referring to our son. The vice-principal felt clearly uncomfortable and 
mumbled and fumbled a bit while trying to smooth things out. Then another couple of parents approached us directly and accused our son of being the problem. We were completely shocked.

30 Thoughts like, "This cannot be happening," and, "The principal will surely stop this," and, "Hell no, they will not get away with this," went through my mind. My ex-wife struggled to hold back the tears and at the same time she was so furious and frustrated, as I was.

We stammered something about how it could not be our son alone that caused the problems, and that he was often upset and complaining about bullying and conflicts, when he came home from

35 school. We looked at both teachers and principals in the hope that they would come to our rescue. The

3: Rejecting, denying and silencing parents' perspectives conversation went on like this, with other parents accusing us for our son's misbehavior and threatening that they would move their children to another school, if we did not move our son. This ultimatum was not

contradicted by the school professionals. When we realized this, we rejected the legitimacy of their attack and left the room. Our son did not go find another school but started at We moved his
4: Positioning the family as problematic- the problem is exported into the home/family come to school the next day, another school immediately. little sister shortly after. 


\section{What was constructed?}

The interaction between the family and the school was contextualized around misbehaving students and dissatisfied teachers. The overall rationale of the school was an acceptance that students misbehave in school. However delicately, the school brought forth the understanding that individuals, in this case students, were to be blamed for interactive troubles. (This is an example of what McNamee and Gergen (1999) call rituals of individual blame). Thereby 'the individual' was appointed as "the problem". Since they were not understood, addressed, or cared for, the interactive troubles continued. Maintaining rituals of individual blame allowed for the continuing presentation, repetition and substantiation of the problem story. Student's voices and perspectives were not involved in the communication, and their stories of bullying, conflict and disaffection in school were not listened to or valued. The perspectives of the parents were silenced and not given merit. As a consequence they were positioned as unworthy of engagement in respectful collaboration and as problematic. The problems increased. In the context of lack of constructive responses from the school, the parents were left alone with their son feeling miserable in school. Since other students in class were suffering from the interactive troubles that were not dealt with, the frustration among other parents made them unite in the individual blame of the one student as the problem. The blame and the responsibility of causing the problem was put on one family, and thereby the responsibility for solving the problem was exported into this family. This left them with not many options for action. Given the lack of a relational approach and understanding, the co-creation of interactive troubles was overlooked.

The larger pattern of interactions among students and among students, teachers, and the school, as well as among the group of parents, was overlooked. When the school refused to acknowledge the larger pattern of interactions, it effectively accepted the appointing of the one student and his parents as scapegoats, which turned the situation into an ultimatum for the family; either they accepted the situation and interpretation of their son, or ultimately they could find another school. Since the situation was unacceptable for them and since no solutions were ever suggested to solve the problem, in fact the family had no other choice than to move their son. The spiral of exclusion resulted in the final exclusion of the family, including the little sister.

So what could have been done differently to avoid the exclusion of the family? First and foremost, had the school stated that interactive troubles are in fact interactive and not the result of a single person, the stigmatization of the boy would not have had any grounds. This would indeed have implied that the school took responsibility for the culture in class and for engaging students in cocreational, collaborative and respectful ways of interaction. The school professionals might have 
engaged parents in collaborating around the co-creation of a safe and fruitful learning environment for all students. Had the school worked to strengthen relationships and friendships, the chances would be that issues of conflict and bullying in class would decrease. When students thrive and learn, parents are generally satisfied and supportive.

The school might have focused on improving learning and wellbeing in school and on finding ways of engaging students and parents in exciting and collaborative learning projects. Had the school succeeded in taking on its professional responsibility and in being pro-active, the chances that the rejection, separation and exclusion of the family by the other parents, would not have been present. Much frustration and despair would have been avoided. For the boy appointed as the problem, and as a scapegoat for the school and finally being excluded and moved to another school, it is most likely that these experiences put scars on the soul. If he were instead engaged in collaborative, respectful ways of dealing with interactive troubles, he would have come out with not only strength, hope, and legitimate power, but also with skills of dealing with interactive troubles in relational, respectful and restorative ways. This goes for everyone involved in this case.

\section{Story 8 \\ Why are they not listening?}

"It began after the summer holiday in third grade, where I quickly got to know that there were problems with my son, Jeppe, in school. The school contacted me a couple of times and asked me to come pick him up because they had even sent him

\section{1: Appointing the student} as the problem they could not control him. Another time home, even though they could not get hold of me, so I did not know. That same evening the teacher called me and explained that they had been forced to send him home, because the conflict had escalated between him and the teachers. I said it surprised me, because he was behaving very normally at home and thrived in the Leisure Club, too. They ignored this statement.

After a few weeks, the situation had gone really bad. It was out of

10 hand. Another day, Jeppe had shouted and screamed in an argument with two other boys and had not been willing to stop. This time I asked what the

3: Rejecting, denying or silencing parents' perspectives school intended to do to help Jeppe. I got no answer, but was let know that the school was convinced that Jeppe's behavior may be due to a miscommunication between me and his father. The teachers knew that we recently had divorced. They said that they would suggest that we contacted the Family House. I was so shocked and surprised. Of course I would contact the Family House on the school's 
request, but I could not believe that the teachers did not know how to help Jeppe and the other students in the class to interact better. The only thing they had previously done was to send Jeppe to the disciplinary office in situations that were out of hand, both during classes and recess. The conversation went on. I said that I could not see what Jeppe would learn by being sent away to the disciplinary office alone and away from his friends. He would not learn any new skills from this. So I asked what the motivation was.

They explained, that they could not use the time during class to handle him. They said, "He must be brought to understand." These words paralyzed my thoughts for a while. Did I hear correctly? Did they really say that? If anyone should be made to understand, it was them. They were the professionals who were educated and who had the ultimate responsibility for students' wellbeing and learning. How come they did not feel the obligation to try to understand what was happening around my son in school?

At the end of the conversation, I was offered twelve hours of observation of him. Some teacher would then come to class randomly and observe what was going on. I asked some questions about the observation-plan, since I didn't feel good about this. What would they be looking for? Who would do the 2: Repeating the problem story observation? With what purpose? And what would happen afterwards? They had not really any well thought-through answers. So I suggested that support was given in the class both during lessons and recess, so Jeppe and the other students could get some help in playing together in good ways. It was rejected and the offer of twelve hours of observation on Jeppe was settled.

Some weeks later, I received an eight-page letter based on the observations from the teacher team about the terrible things my son did, and all that he was not able to do, and everything he did wrong. Eight pages! I called the teacher and said that I had always believed it when they said there were challenges with Jeppe, and I did not need eight pages to believe it. At the same time I asked what the school had gotten out of the twelve hours of observation on him. How did they intend to use the report and what ideas for actions had the observation given them? Nothing, said the teacher, but the report had confirmed them in their thoughts that the reason for Jeppe's bad behavior was some issues at home - and that the school could not handle him, as long as he continued to behave like that. It was very discouraging.

Shortly after, the Principal convened Jeppe's father and I to a meeting to talk about our divorce and the way we cooperated and

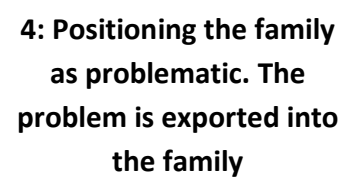
communicated. I couldn't believe it. How come we were to talk about this with the school principal? 
Why couldn't we talk about possibilities to help Jeppe? We had no influence on the date or time of the

meeting, nor the

several times, but I

daytime and I had

\section{5: Turning the} situation int50 an ultimatum

subject or the content. I wrote emails and called the principal couldn't get in contact with her. The meeting was during a lot of difficulties getting permission to leave work. At the meeting, which both the principal, the vice- principal and the three teachers attended, we were told that the reasons for Jeppe's aggressive behavior in school were due to our divorce and poor

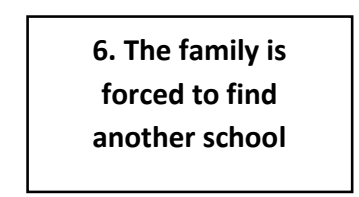

55 communication. It was so humiliating and frustrating. I struggled to not feel crazy. I tried several times to change the conversation and asked over and over what the school could do to create a better learning environment for both Jeppe and the class. Something that made them better friends again and that did not exclude Jeppe all the time. He was kept away from the rest more and more and it became increasingly difficult for him to get back into the group. All that I said was dismissed. It was as if they

60 disclaimed any responsibility for taking action and for doing something to get Jeppe and the other students in the class out of a vicious circle. If anything, this meeting only made things worse - both between my ex-husband and I, Jeppe and his father, us and the school. Shortly after, I started taking Jeppe with me to work. I am a teacher, too, and my principal allowed me to bring Jeppe to my school for him to attend classes. Things kind of eased out from there, but I knew it was not a permanent solution." 



\section{What was constructed?}

As seen in the other stories, the interaction between the family and the school in this last story was contextualized around the school appointing the student as the problem. The problem story was laid out over and over by the school professionals, and substantiated with numerous examples and later the eight page observation report. The student's and the parents' perspectives were not listened to, involved or valued, but rejected and silenced. Furthermore, the school accused the parents of being responsible for their son's situation in school.

The explanatory model was that the divorced parents needed to work out their communication and relationship. Not only was the school invading the private sphere of the parents, but also making assumptions, judgments and accusations. They assumed that the parents had a destructive relationship and communication, and that it was this that was causing the interactive troubles in school. What was assumed here was a causal link between the parents' communication on the one side, and on the other side the relationships around the boy, the other students and the teachers. What was entirely overlooked, however, was what was going on in the school. How was the learning environment arranged? What kind of activities were the students engaged in? How were the professionals responding to the situation? How did this response impact on the boy and his relationships? How did the boy interpret the situation himself, and when was the problem not a problem? And so on. In other words, what was overlooked was the larger pattern of interactions in school, while the whole focus was put on the parents. As a consequence, the parents were positioned as problematic and as causing the problem. The problem was placed in the family and the responsibility for solving it was exported to the family. The school missed out on the opportunity to take professional responsibility for dealing with interactive troubles in schools and thereby also to establish a worthy learning milieu for the students in class. Having placed the problem within the family, not many options for action were formed for the parents. Even if they could work on their communication, it would not help the student in class - at least not in the short run, if ever. The situation turned into an ultimatum; either the parents accepted the situation and the positioning of their son and themselves as 'a problem family' or ultimately they could find another school. Since the situation for the son was unacceptable, the only option was to move him to another school. The result of the process was the final exclusion from the school.

How might things have evolved differently? When the school professionals discovered that something was not working in class and that this 'something' was influencing the student inappropriately, the teachers might have looked for ways to develop the relationships in class and to improve the student's position in class, instead of looking for his deficits. Avoiding appointing the 
student as a problem might have paved the way for establishing a better collaboration with him, where he could show himself as a worthy contributor and member of the class community. Avoiding appointing him as the problem would also have made possible a better and co-responsible collaboration with the mother, where her resources and knowledge could have informed and qualified the process. Not only is she the mother of the child, but she is also a teacher herself with the same formal knowledge and competences as the teachers at her son's school. Had she had the chance to contribute instead of being put down and stigmatized, more nuances and other ideas and possibilities could have emerged. Had the school professionals engaged other students and parents as well in the co-creation of a strong class community, the individual student would not have been stigmatized and excluded, but efforts would have been put on strengthening relationships and the learning milieu. The mother and the child would not have experienced so much suffering, frustration and stigmatization. Possibly, the teachers would have learned about ways to improve relationships in school, and ways of dealing constructively with issues of interactive troubles, instead of reproducing rituals of individual blame.

\section{Analysis findings}

The pattern that was found across all of the stories is quite important. It shows that students and families are not only influenced by exclusionary processes, but that they are also actually being excluded from the schools. The exclusion appears in these stories to be a result of specific practices evolving around responding to interactive troubles. An important element in the spiral of exclusion is that school professionals do not seem to know what to do or how to handle interactive troubles such as bullying and conflicts. Another element is that parents are not considered as resourceful and worthwhile, and are pushed away in situations where an enhanced and closer cooperation is in fact sought for. Already the first step, which is appointing the student (or in some stories the family) as the problem, opens up for rituals of individual blame. The problem story of the schools entail deficit-and problem descriptions of the students. In chapter 3 it was outlined that a person is defined by the stories that are told about her/him, and that too often, stories are told about people where the emphasis is on the voice of the professional, not the voice of the person (Blatt, 1981; Kliewer \& Biklen, 1996). In the meeting with the schools, the families are faced with such deficit- and problem descriptions of their child, making the whole family look deviant and as the cause for the problem situation. Here, interactive troubles are not understood as co-created, but as individual problems. School professionals do not listen to students' and parents' voices, but instead deny, reject, and silence them. In a couple of the stories the school 
professionals do not respond, and do not take students and families seriously, which is in fact devaluing and ignoring them. Due to rituals of individual blame and in the lack of knowing how to do things differently, the problem is exported into the families, as well as the responsibility for solving it. This means that school professionals miss out on the opportunity to take responsibility for the interactive troubles in schools, which makes them appear as unwilling to learn or to look at their professional practices.

The families that are sharing their stories in this study are well-educated and active in the labor market. They belong to "the middle class". They are well-functioning, self-supporting and 'not known to the public social system'. Thus, the children in the stories are NOT coming from socially vulnerable families, abusive families or poor upbringings. Therefore, the traditional template of reproduction theory as an explanation of why children and families get into difficulties in meeting with schools, cannot be used. When the usual model of explanation, which says that the causes of a child's difficulties in school are to be found in the family background, cannot be used, new questions and new ways to understand what is happening are required.

The exclusionary pattern is important for several reasons. What it does is to produce a structure of relations. Not only the students and families directly involved, but also the school professionals and the wider school system are influenced by the exclusionary practices. The wider school system contains the whole population of professionals and students in school and their families that are witnessing, contributing and learning from these cultural practices. The pattern systematically holds school professionals, students and families in specific relationships. It produces at-risk positions, and works against the intentions of inclusion. It substantiates a certain way of relating, that blames individuals, focuses on problems and avoids taking responsibility. It individualizes what is in fact interactional, relational and social. It prevents schools from learning from parents' and students' perspectives, and it silences voices that have a legitimate right to speak and be heard. In addition, students and families are perceived and positioned as problematic, and as well they are 'exported' to other schools. What we see is a reproduction of a pattern, where families are delegitimized and schools are legitimized.

It is important to state that exclusionary practices evolve in the context of a lack of more appropriate ways of responding to interactive troubles. The way the schools respond hinders a caring, collaborative, multi-vocal and prosperous conversation around responding to interactive troubles. It reproduces a pattern of relating that has many serious, unintended, negative consequences connected to injustice, loss of face, marginalization, stigmatization, as well as the production of 'education-hostileyouth'. The practices around interactive troubles are placing students and parents (that were not 
marginalized in advance) into marginalized and at-risk positions. Instead of fostering learning and the fulfilling of potentials, these practices emphasize submission, alienation and social control.

\section{Beyond the visible}

\section{Assumptions behind the exclusionary practices}

After having shown how the exclusionary pattern evolved around the specific actions done by the school professionals, it becomes interesting to ask why the school professionals acted as they did. What ideas and assumptions, or discourses, made them act like this? Behind any practice lie some basic assumptions. However harmful to the families and to the relationship between school and family, it is these assumptions that render the actions of the school professionals meaningful to themselves. As depicted earlier in this chapter, each of the steps in the spiral of exclusion is a moment that matters, meaning that it is a moment where the school professionals took a decision to act in a certain way. Each decision is based on assumptions that guide the making of the choice. We shall now look into some of these assumptions.

The entire exclusionary process is based on a compound of assumptions. Appointing the student as the problem is based on the assumption (1) that what is can be described in an objective, neutral and unambiguous manner. This also implies that a person, such as a student, can be observed and described objectively. Using a systematic approach and being observant and neutral is believed to make it possible to describe a student exactly as he is. The eight pages observation report in the story with Jeppe is an example of this. Here it is assumed that the observation can give a 'true and adequate' picture of Jeppe's difficulties.

The assumption is continuous across all of the stories, where descriptions of students are made by the school professionals, without considering the benefit of including other and differing perspectives on the student. The assumption is also at work in regard to step 2 in the exclusionary spiral. When the problem is found, the problem story is presented and, if necessary, repeated. Examples of the disorderly behavior of the students substantiate the problem story. Since the problem story is an account of the truth, the logic is that there is no need to involve differing and alternative perspectives, such as the voices of students and parents. This first assumption leads logically to the next. When the schools present the truth of a child, parents must necessarily accept this. Within this assumption, a denial to accept the truth is seen as an (incomprehensible) protest and a proof of the parents' as being 
troublesome. The assumption prevails on the parents to comply with the worldview of the school and accept the positioning of their child as a problem.

Such expectation of parents to be willing and apply a collaborative attitude is found in other studies (Dannesboe et al. 2012; Madsen, 2008; Knudsen, 2008; 2011). As referenced in chapter 2, the researchers state that parents are afraid to express opposing views or criticism out of the concern that if they do - it will negatively influence the way their child is being treated (Dannesboe et al., 2012). Dannesboe et al. show that parents make every effort to adapt to the school's expectations for them to show confidence and trust in the school's judgments, even in cases where they - when they get home are in doubt or have many questions and criticisms. This is also seen across the stories in this study, for example, where parents accept the request to meet with the school during worktime, even though it is jeopardizing them at work. It can also be seen when the mother of Jeppe repeats over and over that she does not need an eight-page observation report to believe that there is a problem. The same counts, when parents accept the temporarily isolation of their child from class community to think about it, or when parents politely keep offering their perspectives and keep behaving nicely, even though they are rejected and silenced by the school professionals. In all of the stories the parents are struggling to maintain a collaborative approach in the face of insults and humiliations.

The third assumption is that a child is as he or she is, and acts the same in all situations. A person is seen to have a fixed character that is unconditional of events, relationships and contexts. Within this assumption, school problems are seen to be caused by students' personal characteristics, individual flaws or deficits. Therefore, when a problem occurs, the causes are searched for within the individual student. This leads to single-minded deficit descriptions of individual students. Working on this assumption, the observations made by the school professionals on how the child is are seen to logically be in correspondence with the truth, which makes it unnecessary to obtain contradictory information and experiences from others. It seems not just irrelevant, but out of the question to try to create a more nuanced picture of the child's behavior and situation, by including perspectives from parents, pedagogues in leisure clubs or from a football coach. If a child is a troublemaker in school, it is also very likely a troublemaker everywhere else. If parents argue that the child is behaving well at home, they are just covering up or distorting the truth, or perhaps even lying.

This same assumption is activated in relation to the understanding that parents are as they are. Therefore, it is wise for school professionals to get to know parents in advance so as to categorize what type of parents they are. The categorization of parents becomes part of preparing oneself according to which parents are cooperative, and which are critical. This assumption was clearly in play in Knudsen's 
research that was referenced in chapter 2. At the end of the training course in conducting difficult conversations, it was the common understanding among teachers and principals that it was important to take care of oneself in relation to parents as well as to back up each other, when exposed to difficult parents (Knudsen, 2008). Within this assumption lies a positioning of 'us and them', where each stand on each side and against one another. This assumption is seen in all of the stories, where teachers and principals pair up, back each other up, pass on the word to each other, while ignoring the wish to speak from students and parents. This is seen in the story with Lea, where the principal convened the parents to a meeting, because he had heard that they were critical of one of the teachers. Extraordinarily, this meeting was settled despite the continuous attempts from the parents to have a meeting to talk about the wellbeing of Lea in school. In comparison to the assumed critique of the teacher, the wellbeing of Leas was treated with far less concern.

This assumption that critical parents are as they are leads to the fourth one; School professionals need to stand up to parents collectively. This assumption led the principal to show more care to the teacher than to Lea and her family, even though the situation for Lea and her family was far more critical, than the one for the teacher.

The fifth assumption is that it is the parents' duty to deliver a well-behaved and teaching-ready child that is able to understand and comply with the school's standards. It is perceived that school standards are natural and apply to everyone and everywhere - including every family. If a child does not comply with the school's standards, it can only be due to one thing: parents failed in their duty to teach their child the standards that apply everywhere. This assumption points to failures in the families whenever interactional troubles occur in school. It gives rise to the explanatory model that problems in schools are due to misbehaving and not-properly-raised children. If parents can be brought to understand this - and take on the responsibility to raise their children according to the demands of the school - there would be no school problems. This assumption hinders school professionals from creatively looking at school practices and from experimenting to improve the learning environments in situations with student dissatisfaction in school. The utterance of school professionals that "Jeppe must be brought to understand" (this chapter, p. 40) is an example of this assumption. It is not school professionals that must be brought to understand how to help Jeppe, which seems as least as legitimate a thought. The assumption ranks school structures before students, and initiates processes of making students fit the school instead of organizing schools and offering learning opportunities that are invitational, responsive and caring of students. By blaming the student for being a problem and the 
parents for not having raised their child properly, the problem is exported into the families - not only the responsibility of causing problems but also for fixing them, as seen across the stories.

The sixth assumption says that the right way to solve a problematic situation is by analyzing and identifying causes to the problem. Who is causing it? Why does it occur? How bad is it? And so on. When the causes are found and identified, it is believed to be possible to find out what can be done. This assumption combined with the first one leads school professionals into analyzing what is wrong with the individual. However, in none of the stories, is it quite clear to the parents how the school professionals have used the problem descriptions of student deficits to reach conclusions on what causes the problems. In the story of Jeppe it is a mysterious how the school professionals from doing the observation on Jeppe's deficits came to the conclusion that the causes for the interactive troubles in schools was due to poor communication between the divorced parents. After all, eight pages of observation have not been written about the parents' communication (which would be rather unusual, anyway). Yet the school professionals feel justified in ascribing Jeppe's problems in this direction.

Reflecting on all of the stories, it is a mysterious how the school professionals use problem descriptions and problem analysis to reach solutions, since in none of the stories do school professionals come up with any constructive responses or suggestions on how to help the students with troubles in school.

Combining the assumptions gives rise to the belief that, when causes to a problem are found inside a student, it is necessary to confront the student with his deficits in order for him to change. It is presumed that the change occurs when he acknowledges his misbehavior, because he then can selfadjust into better behavior. This is seen in various ways across the stories, for example where students are sent to AKT or home to 'think about it'. This counts as well when the school professionals try to convince the parents that they are to be blamed for the problem. If parents would just acknowledge that, they can change themselves and undo what they did wrongly.

The assumptions are combined in opaque combinations and all together they guide the actions that create the spiral of exclusion. They can be summed up like this:

- There is a universal real world out there. The implication is that it is necessary to describe it.

- Descriptions can be made objectively and without affecting what is described. The implication is that descriptions are made without taking into account how they position the persons.

- Objective descriptions of the truth can be made by school professionals, which parents must accept. When school professionals present the results of their observations, parents must 
accept this as the truth. The school professional hold the right to define the truth. They are one-up against the parents. The implication is that there must be something wrong with parents that do not comply with the worldview of the school.

- A person has a fixed identity and acts the same in all situations. One implication is that it is important to find out "what kind of person it is" (parents and students), which leads to categorizations.

- Another implication is that school problems are caused by individual deficits in students. A third implication is that difficult collaboration with parents is caused by parents being difficult. A fourth implication is that school professionals need to stand up for one and another and against difficult parents. Parents are as they are. Are there problems with parents it is because there is something wrong with them. A student is a fixed identity and acts 'the same in all situations'. If there is a problem with a student it is because something is wrong with him/her.

- Parents are obliged to deliver 'a teaching-ready child', that is, a child that is willing to comply with the school's standards. The implication is that, if school problems occur, it is due to the failure of the parents to raise their child properly. Another implication is that there is either something wrong with the student or with his family, if he does not fit the demands of the school.

- The correct way to solve problems is by analyzing the problems and identifying the causes. Solutions are found through identification of causes in the person's deficits. When people acknowledge their deficits, they can undo, what they did wrong. Finding solutions to problems must be based on a problem analysis that results in identifying the causes to the problem.

These assumptions do not just live a quiet life, but strongly guide actions and the events as they unfold. They appoint students and parents as 'problems', blame them for not collaborating (complying), export the responsibility for school issues into the families, and prevent schools from responding constructively to interactive troubles, which ultimately lead to the final ultimatum. Either the parents comply with the positioning of them and their children as problematic and accept that the schools cannot solve the situations, or they go find another school. Altogether, the assumptions form the practices that are ultimately exclusionary. They lead to rituals of individual blame for issues that are in fact contextual, social and relational. They govern the selection of actions and give legitimacy to the actions done by the school professionals. The assumptions are not put into words, but work as drivers for what happens. 
So what characterizes the assumptions behind exclusionary practices? First and foremost, they share an emphasis on focusing on problems, individuals and deficits. The deficit assumptions are governing the selections by the school professionals of what is important. School professionals choose to do what they do, but they could have chosen to act differently. Their choices are determined and legitimized by the individual, problem and deficit assumptions. Had the school professionals acted differently - as shown in the figure xx Moment that matters - other courses of events would have emerged.

Virtually, each of the steps is a potential spin-off to another spiral perhaps more inclusionary. Unfortunately, these potential spin-offs are suppressed and not actualized. The spiral of exclusion is a series of moments, each one slightly different from another, but still so similar in the way that they blame individuals for relational and interactive troubles. Even though the steps are slightly different from each other, they are not different enough to create something radically different such as dignity and respect for example, or listening, collaboration, mutual exploration and so on. What these assumptions are blind to are the competencies, the resources, the relationships, the events, the hopes, the dreams, the ethics, the moral purpose of education, the voices, the perspectives, the differences, the nuances, the potentials, and the becoming somebody of the student. In the words of Pearce, the assumptions are blind to what social worlds we are creating in the making/moment.

\section{Discussion of findings}

The analysis showed many unintended negative side-effects of the ways the schools dealt with interactive troubles. What started as a wish to create something good and helpful can end up in dashed hopes and broken relationships. The bullying issues that are present in several of the stories are not addressed, which results in the continuation of bullying relationships, bully interactions and bully positions as well as parent-school conflicts. Bullying is known to have lifelong negative consequences, not only for the students directly involved, but for the whole class environment both in terms of learning outcomes and wellbeing (Hansen, 2005; 2009; Kofoed, Henningsen \& Hansen, 2013; Søndergaard, 2009).

As models of relating what the school professionals performed is likely to have crucial impacts on what the students grow up to believe is adult behavior in dealing with interactive troubles of different kinds. It is likely that students that find themselves in need of adult support in school will not feel safe and trustful enough to address the school professionals. Doubt about whether they will be listened to 
or whether the professionals will take any action is legitimate. Besides the negative effects of the immediate experience, exclusion and marginalization can have constitutive and longitudinal implications for students. This implies an outsider-position in regard to the current school community in which the interactive troubles take place, or later on it can imply marginalization from a broader education community or even a whole society. On a large scale, students involved in - and feeling the backlash of - exclusionary practices in dealing with conflicts risk marking "collaboration" with professionals as uncomfortable, worthless and pointless. Hereby they miss out on the possibility of learning and mastering constructive ways of successfully dealing with interactive troubles. From a societal viewpoint which emphasizes the need for democratic competence, this is a severe threat.

For the school professionals living out these practices, everyday life and work in schools are made unduly burdensome. The practices around dealing with interactive troubles make collaboration with families extraordinarily difficult. Teachers miss out on collective learning possibilities and lose sight of the perspectives and wellbeing of students. Teachers might come to learn that they have little power to solve interactive troubles, which contradictorily will reproduce the practices analyzed. Issues of bullying and negative interactions among students will continue, making teaching and school life difficult. Teacher empowerment and agency are at risk as well. Furthermore, the communication forms performed by the school professionals are in danger of creating a hostile and problem-focused work community with few options for organizational learning and progress.

For the families experiencing them, exclusionary practices might have far reaching implications. Losing face was an issue for all families in this study, and finding ways to act competently was difficult in each case. The doubt created by being blamed was not beneficial to the relationship between parents and children. Questions such as the following arose: Has our child been acting in such ways as the school professionals describe? Are we blind to something? Have we neglected some signs? Have we let down our child in some way? How come we cannot succeed in creating a good collaboration with the school? Are we such a horrible family? Furthermore, the stigmatization of their children as problems might pop up in other situations and relationships, where the parents would be more focused and aware of the child's potential for "rascal" behavior.

The families not only experienced being stigmatized themselves, but were reinforced in their worry about the stigmatization of their child by the school professionals' way of handling issues of bullying and interactive troubles in school. A profound mistrust developed towards the school professionals. This concerned their professional skills, their will and intentions, and their status in society. Parents were left in frustration and with the responsibility to "solve the problem and do it at 
home". The exportation of the problem served to exempt the schools from responsibility to take action. The families' experiences of the failure to establish an equal and dialogic conversation about possibilities to help the students entails the risk that parents mark school-parent collaboration as unpleasant and pointless. As long as these practices are performed, parent-school collaboration in dealing with interactive troubles will be difficult, if not impossible, and most things in need of being dealt with collaboratively will not be successfully addressed. The continuation of exclusionary practices and negative family experiences are most likely influencing the increasing distrust in public schools in Denmark.

\section{A preview of chapter 6}

In the next and final chapter, I shall first address theoretical and practical implications of the study results, and secondly address questions of what could be different, and what this would require. There are various important issues at stake here worthy of consideration. These have to do with the need to rethink common theoretical understandings.

Studying exclusionary practices and the underlying ways of thinking and relating that produced the at-risk positions and the marginalization of students and families in dealing with interactive troubles in schools, contributes to explaining why schools still have not found ways to become ultimately inclusionary for all students (solving the inclusion problem). The paradox is known that schools both reproduce social marginalization (Elsborg, Hansen \& Hansen, 1999; Jensen, 2015; Jørgensen, Blankenberg, Skall \& Schjerbeck, 2016; Smyth \& Hattam, 2004) and make it possible for youth to positively break a negative social pattern (Phil, 2014; Ejrnæs, 2011; Jæger, 2003). But what this study shows is that schools are also producing at-risk positions for students that were not marginalized in advance. Amongst other things, this implies a need to go beyond reproduction theory to understand atrisk youth, since reproduction theory cannot explain the social marginalization of middle class youth that evolves around dealing with interactive troubles. Instead of using reproduction theory as the explanatory model for at-risk youth, it is a more honest and promising approach to look into the constitutive structures of exclusionary practices and the underlying assumptions that lead to the production and reproduction of exclusion and social marginalization in schools. As such, I am advocating for shifting towards talking about the reproduction of practices rather than of types of people. 
To sum up on this I shall discuss what can be done differently and lay out some broad ideas here. Even though the spiral of exclusion is strong, it is possible to point to alternatives. Each step in the spiral is a potential spin-off. If school professionals make use of other assumptions, other actions and choices become intelligible. We must turn to ways of thinking that produce positions, relationships and interactions in schools, so that inclusionary processes can evolve in which students can become somebody worthy of respect, influence and contribution. 
Chapter 6

\section{Implications}




\section{Moving to the final conclusion}

This study sprung from a curiosity about why and how exclusionary processes in schools evolve, and furthermore, why and how families find themselves positioned in unworthy positions with not many options for agency. Thirdly, it was of interest why and how these practices seem more or less institutionalized or at least ritualized in situations around interactive troubles. Finally, the study sprung from a wish to find out how NOT to respond in exclusionary ways, but instead to find inclusionary ways to respond to interactional trouble. Thus, the study was guided by two research questions that I shall include as a reminder:

1. What ways of thinking produce exclusionary processes?

2. How can school professionals change exclusionary processes into inclusionary ones in a way that supports students becoming somebody?

The research questions were operationalized and turned into propositions that I have examined.

1. Various ways of thinking are related to various epistemologies. Ways of thinking are grounded on basic assumptions about the world: what is truth, what is a problem and what are the ways of approaching problems. By looking at the communication and how it produced the exclusionary processes, it was possible to identify the basic assumptions behind the practices.

2. When a specific way of thinking leads to exclusionary processes, it must be possible to create inclusionary processes by using another way of thinking. When specific kinds of communication create specific kinds of positions and options for action, other kinds of communication must create other kinds of positions and options. Based on such knowledge it is possible for school professionals to change what is in danger of becoming an exclusionary process into inclusionary processes. Thus, school professionals CAN create inclusionary processes for all students that entail the becoming somebody with positive significance to relationships and the (school) community.

Thus, in this final chapter, I shall answer the research questions and sum up the entire study. First, I shall discuss the findings in order to offer a conclusion on the study. Secondly, I shall elaborate on the implications of the study's results, discerning between theoretical and practical implications. 


\section{Conclusions}

The analysis of the data collected for this study shows that problem-, deficit- and individualistic assumptions dominate school practices to such an extent that exclusionary processes unfold. The study shows that in various ways these assumptions produce and reproduce exclusionary processes and at-risk positions that mute, devalue and exclude students and parents. Furthermore, this happens to students and families that are not otherwise affected by social marginalization.

As this study shows, there is sometimes a harsh struggle between the school and the parents, where the parents are struggling to maintain a worthy place for the student, when in fact the school has put the young person in a marginalized position and caught him or her and the family up in exclusionary processes. Højholt (2006), Knudsen $(2008 ; 2010)$ and Smyth and Hattam (2004) raised similar claims, as referenced in chapter 2 .

This serves poorly the task of providing options for students to become somebody. Parents experience frustration, accusation, recrimination and mistrust from the school, while their child is caught in failure to thrive in school. This seems like a double injustice. Their options narrow down to accepting the problem story about their child, or alternatively to reject this premise and leave the school. If parents try to establish other terms for the cooperation they are perceived as troublesome and problematic. This was found by Haslebo and Lund (2014) as referenced in chapter 2.

The marginalization is unintended, as well as contradictory to the moral purpose of schooling. However, it happens due to the particular types of interactions that are both based on and productive of a deficit way of thinking as well as reproducing the deficit positions that students and parents are given in these interactions.

The deficit discourse absorbs all stakeholders and keeps them caught up in an exclusionary spiral. Although students and parents want to and try to speak, they are not listened to. Both students and parents act and perform agency in the way that they try to resist and protest against the positioning of themselves but with not much success. From the short stories provided by parents, we learn, that what parents say, their contributions, suggestions, and perspectives, drop to the floor. It is mostly ignored and not included. For "the word and, consequently, for the human being there is nothing more terrible than a lack of response" (Bakhtin, 1986, p. 127). All the stories are examples of families being silenced of not being heard. As Roman (1996) argued, even if students are invited to the table, they are most often not heard, because they cannot 'speak' from outside the deficit discourse - or even if they try to do so, they cannot be heard, because what they say is heard from within the deficit discourse. The deafness that they are met with is caused by the fact that they refuse to speak within the deficit 
discourse. This refusal is an act of agency and in the word of Freeman (2010) it can be seen as a protest against how they are positioned.

The limited options for acting go to the school professionals as well. They cannot act outside of the deficit discourse, or think outside of the deficit discourse, and, therefore, cannot open up to creativity and so they repeat the pattern. The school professionals are not showing the ability to listen to and integrate parental and student voices in their practice, which makes school-family collaboration unduly difficult. It can thus be assumed that the school professionals suffer from not having been trained to respond successfully to interactive troubles.

Schools often export the responsibility for solving interactional troubles in schools into the families and thus deny their own responsibility and miss out on the ability to include and create an inclusive learning community. (Madsen $(2005 ; 2008)$ and Knudsen $(2008 ; 2010)$ argued for similar findings as referenced in chapter 3 ). This leads to the privatization of responsibility into the family. As a result, schools are giving themselves a bad reputation among the families, with the risk that public confidence in the teaching profession is degraded. Ultimately, exclusionary practices that result from responses to interactive troubles are threats to schools, because they make inclusion difficult and prohibit schools from fulfilling their moral purpose.

In the stories, we saw that what was repeated was the production of deficit positions, of blaming, of individualizing and of avoiding addressing conflicts. Across the stories, individual-, problemand deficit-focused thinking was repeated, showing a larger picture of repetition, indicating that these practices are habitually performed in dealing with interactive troubles. (This fits with the rituals of individual blame that Gergen and McNamee (1999) warn about as we saw in chapter 3). One can imagine school professionals having hundreds of such interactions with many families again and again and throughout a school year, or even throughout a whole working life. It is possible to imagine students and families trapped in such interactions over and over and teachers and principals having no other 'methods' to turn to or no other concepts to draw on.

The data collected for this study suggests that:

1. Responding to interactive troubles from deficit-, problem- and individual thinking produces exclusionary processes.

2. Thus, parents and students not yet "at-risk" become marginalized.

3. These processes are happening in school, however invisible they are to most people.

4. It does not have to be like this, since other assumptions and ways of thinking exist that could have led to different kinds of interactions, relationships and processes. As we shall see later in 
this chapter, there are, in fact, other ways of responding to interactive troubles that have proven their merits in educational settings.

\section{Producing, reproducing and repeating exclusionary practices}

The practices studied in this research do not appear to be a reproduction of social class differences, but of ways of interacting and relating that are ultimately exclusionary. What is created is not only generational, but also interactional and created in the making. Production is when not everything is structured, but produced in the moment. Production becomes reproduction when it is repeated. In interactions ordinary families are positioned in deficit positions, which marginalize them and categorize them as "at risk". In chapter 3, Freeman (2010) raised similar arguments. What is both produced and reproduced are the individual, deficit and problem assumptions.

Traditional reproduction theory has contributed the understanding that some things are structured in advance, such as gender, race, and social and economic status, and that these things seem to be reproduced from generation to generation. However, to say that these things alone are determining of positioning in educational settings would be wrong. In fact, there are also things that get structured in the moment, such as at-risk-positions that are not pre-structured, but created, produced and reproduced in interactions. Benjaminsen et al. (2015) and Ejrnæs (2011) raised similar claims, as referenced in chapter 3 . This discovery is a flaw in the traditional deterministic belief in reproduction theory. When things are structured in the moment by a certain way of thinking and by certain practices and these are negative, counterproductive, unwished and unintended, we should pay very careful attention to how to change it. It could have been the case that school professionals made use of - and thereby (re-)produced - other ways of thinking, that offered resourceful and worthy positions. Then, ways of interacting and relating that are inclusionary could have evolved.

In the following sections, I shall elaborate on these findings, starting with theoretical implications and continuing with practical implications, focusing on what could be different. But first I shall turn to objections, limitations of the study and suggestions for further research.

\section{Objections}

Objections can be made to any study, including this one. And any objection should be included, listened to and responded to. One objection to these conclusions is that teachers are just teachers and 
not social workers. Along these lines teaching is about conveying a curriculum and preparing students to take examinations. All that is outside of this focus is not seen as part of the teaching job. However, it is important to refute such an argument for a couple of reasons. Firstly, my research findings are not asking teachers to be social workers, but to be responsible for the interactions that are going on in the educational setting. Secondly, education is not just about curriculum, but also about social and relational skills, citizenship, nation building, development and identity formation. Ultimately, education is about modeling ways of being together that are crucial for new generations to come. Thirdly, it was democratically decided that the aim of public education was to educate not only for a working life, but for lifelong learning and wellbeing, which rests on the ability to take responsibility for relationships and the wellbeing of others (Undervisningsministeriet, 2013). This implies skills about how to peacefully go on together, regardless of differences. Therefore, teachers are also basically and legally obliged to take responsibility for interactive troubles in schools.

A second objection is that turning difficult family-school collaboration into constructive and responsive collaboration is far too much to demand and ask for from school professionals. It is way outside the main task of a teacher. Again such an objection is based on a narrow and limited view of the teaching profession. In Danish school law, it is explicitly written that the aims, goals and tasks of public education are to be attained in close collaboration with parents. The guidelines here substantiate not only the formal collaboration, such as school boards (with parents' representatives) and yearly familyschool meetings, but also the everyday collaboration concerning the learning and wellbeing of the individual child. This objection rests on the belief that only unproblematic collaboration is part of the job, while difficult collaboration is far too much to demand. When collaboration is under pressure, specific communicative and relational skills are required. These skills are just as advantageous in problematic as in unproblematic collaboration, since they can prevent the collaboration from developing into difficulties.

A third objection may be that all these interactive troubles are, in fact, private issues and not the business of the school. Here it is stated that how students thrive, feel and think is their own business and responsibility. This objection seems to be based on a political argument about what is public and what is private. The rationale is that relational issues belong to the private sphere and are not the business of the public sphere, or the school. Again, it is important to refute such objections. Student wellbeing in Denmark, as well as internationally, is recognized as closely intertwined with learning outcomes (Hattie, 2008; Rasmussen et. al., 2015; Undervisningsministeriet, 2016) and, therefore, 
especially important for professional educators to be responsive to and knowledgeable about how to handle successfully.

In Denmark the relation between learning outcomes and wellbeing is related to the highly regarded traditions around dannelse (development) and uddannelse (training), however dannelse is much more than and different from wellbeing (Rasmussen et al., 2015). Dannelse is about becoming a democratic citizen/person. In recent decades of educational policy dannelse has been phased out and emphasis put on uddannelse in order to compete internationally. As a response to this, critique says that we need to revitalize the concept of dannelse so it again can inspire educational policy and practices. What is pivotal in this study is that it expands the current perception of the purpose of education through adding to the idea of dannelse a relational dimension that takes into account the negative constitutive effects of deficit responses to interactive troubles in educational settings. Thus, dannelse becomes relational dannelse (Lund, 2015; Lund \& Haslebo, 2015; Rifkin, 2009) that emphasizes a concern for how educational practices can be designed to enhance the becoming somebody of students.

The neoliberal trend that is seen in many parts of the world and that pushes towards thinking of students in deficit terms inherently produces injustice and distorts the individual student as well as the cohort of students - they are left "off the hook" in an educational setting that cannot cope with interactional troubles in fruitful interactional ways.

The current dominating practices do not set the stage for school professionals to learn anything about the constitutive effects of their actions, and as such the educational organization continues to reproduce the exclusionary process. Extending the idea of dannelse into relational dannelse is a counter argument that emphasizes that education is not just about academic skills and discipline, but about producing socially and relationally rich citizens. Education is about preparing for democracy. Both children and adults come across interactive troubles throughout life and, therefore, skills in dealing with interactive troubles in ways that do not separate, marginalize and stigmatize, but unify and strengthen relationships and (school) communities, are highly needed.

\section{Limitations of the study}

Any study has its limitation, including mine. The first one is that the data consists of only eight stories and not, for example, 20, 50 or 250 stories. On the other hand, had I had 20, 50 or more stories, chapter 5 could not be written in such detail. I could not have actually told the stories, which was an 
important aspiration from the start, not only for me, but for the families that shared their experiences. My purpose was to tell stories that are not told elsewhere. Had I done a quantitative study, I could have investigated how many families in Denmark - or in a specific municipality, for example, were experiencing similar things. Such a study could have provided knowledge about the frequency and the extent of the exclusion of students and families and thereby how ritualized and institutionalized these practices are. However interesting and important, it was not the purpose of this study.

A second limitation is that the stories were collected in conversations with only one storyteller, speaking from the perspective of a parent. The study might had been stronger, if a larger number of participants had been included in the construction of each of the stories, such as spouses, children, siblings, and perhaps other family members, not to mention teachers and school principals and other families in the school. On the other hand, such stories would be not only more lengthy, but also much more negotiated, contradictory and diffuse, and not able to give explicitly strong voices to the parents. Since it was the initial aspiration to listen to parents as subjugated voices and to learn from their perspectives, the limitation is also the strength of the study, because what we hear are in fact parents' voices.

A third limitation is geographical. The eight families sharing their stories live in altogether only four municipalities and a couple of them were even connected to the same school. Thus, the study is related to only six different schools. However, the schools are located in different parts of Denmark from east to west and south to north. This suggests that the findings are not just coincidences or characteristic of one municipality or one school. The exclusionary spirals identified are located in six different schools in four different municipalities throughout the country.

A fourth limitation is that neither observations, nor recordings of parent-school interactions were conducted. The stories were told from recollection, and explored through conversations that sought to recollect the timeline and find out what happened. Facts were not checked, but emphasis was put on the parents' experiences and memorization of the interactions with the schools and, in particular, on how the evolving exclusion made the parents feel and how it affected the students. On the other hand, this approach is legitimate, since observations would have been impossible due to the length of the interactions (up to a couple of years), the unpredictability of the processes (not knowing if exclusion would be the result and not knowing when every day interactive troubles would occur), and the variety of the type of interactions (phone calls, emails, formal meetings and informal abrupt or acute meetings). Another consideration is that, in the swirl of interactive troubles without knowing the outcome, it would be difficult to tell, explain, or draw 'the larger picture' of what was happening. When thinking back and 
reflecting on what it was that happened, as well as knowing the outcome, it is possible to see a clearer picture and, thereby, tell a stronger story. For the audience to be able to actually listen to parents, it was considered worthwhile to present such stronger stories.

\section{Suggestions for future research}

There are still unanswered questions concerning the issue, and thus much to take up and research further. I would suggest examining the following:

1. How many students and families are experiencing exclusion as a result of interactive troubles in schools? How extended is the issue studied? How are the excluded students and families "based" geographically (ex. urban/rural), culturally and socially? What other features or patterns are involved? Such a study may be quantitative, statistics-based and draw on cross-sectional studies.

2. It seems as the issues addressed are not recognized politically and practically. If they were to be taken seriously, how can this problem be addressed politically, strategically and practically?

3. How are these processes experienced by school professionals? Such a study would be qualitative, based on interviews, conversations or a combination of surveys and interviews.

4. How do the exclusionary processes identified in this study affect and impact families that are not characterized by middleclass? Are the processes of exclusion evolving over the same six steps or will they emerge in other forms, directions or not at all? Such a study would invite specific groups of parents to be respondents, and through interviews or conversations they could share their experiences with exclusionary processes. This might be combined with other data concerning affects and impacts.

5. What happens to the excluded students (and families) over the span of a life time? Will they fully re-integrate in new schools or will the stigmatization follow them? How do they reposition themselves or not in various contexts and relationships as youngsters and adults and later on as parents? Such a study would lend itself to longitudinal or cross-sectional studies, involving both qualitative and quantitative data, combining interviews, observations and statistics. This could also be investigated by ethnographic studies of one or a couple of families.

6. How do the exclusionary processes identified in this study affect and impact a) the class community, b) the other families in the class community, c) the school professionals, and d) the school culture? Such a study could draw on conversations, interviews, observations, discourse analysis, 
ethnographic or cultural studies. Confirmation of the qualitative data may be sought by a larger scale, but more superficial, survey approach.

7. In what ways do individual-, problem- and deficit-thinking affect and impact the families that do comply and accept the problem description of their child? How do processes then evolve? Such a study would invite parents that have accepted a problem description of their child (children with diagnoses or categorized as problematic, deficit or challenged) into the research. By conversations, interviews, narrative analysis, discourse analysis, it could study how these parents might be influenced by the individual-, problem- and deficit-thinking.

8. In what ways do individual-, problem- and deficit-thinking affect and impact relationships between a) principals and school professionals, b) school professionals amongst themselves, c) student-tostudent relationships, and as well d) teaching and didactic practices? Discourse analytic research might open up the relationship between particular ways of thinking and speaking and particular actions by schools, teachers, parents, students.

9. How is training for school professionals in responding to interactive troubles addressed at teacher training institutions, and how might this be practiced in schools? Such a study would examine the discourses, the curriculum and training practices at the teacher training institutions and compare this to practices (and discourses) in schools.

10. How might schools change basic assumptions or epistemologies, when they realize the negative constitutive effects of individual-, problem- and deficit approaches? Training programs aimed at introducing such changes will need to be evaluated. Studying changes in basic assumptions might be longitudinal and would draw on cultural, organizational, practical and discursive studies, combining conversations, interviews, document analysis and observations of practice. Discourse analytic research might open up the relationship between particular ways of thinking and speaking and particular actions by schools, teachers, parents, students.

11. How might school professional working within a relational-, resource- and resolution-focused discourse respond to and faciliate the collaboration with families in situation with interactive troubles? Such a study would examine relational-, resource- and resolution-focused responses to and facilitation of collaboration with families in situations with interactive troubles. It could be conducted similar to this study at hand.

12. How do families and students experience participation in processes based on relational-, resourceand resolution-focused approaches? Such a study could be similar to the study at hand. 
13. How can social marginalization in society be studied and responded to if not based on reproduction theory? Replacing or supplementing reproduction theory with resistance theory, agency theory, positioning theory and discourse analysis might provide whole new images of social marginalization in societies and therefor also of how to prevent, work with or curb for the negative social reproduction that traditionally have appeared to be very difficult to prevent.

The rest of the chapter is devoted to pivotal implications for theory and practice, and especially to what could be different.

\section{Implications for theory}

It is clear by now, that identifying and analyzing the exclusionary practices in schools has farreaching implications, not only for the people involved and for the schools, but also for theoretical understandings. In the following section, I will lay out some important fields of theory that we need to reconsider.

\section{The need to rethink reproduction theory}

In the literature review, the comprehensive research of Benjaminsen et al. (2015) was

referenced. The surprising discovery of their study was that youth from all kinds of family backgrounds are at risk of being socially marginalized. The population of their field of study is illustrated in the chart in Figure 6.1. Vertically, the chart depicts two categories of youth; those that receive and continue the social status of their parents, and those that break the pattern of social status. Horizontally, the chart depicts two categories of families: middleclass families and socially marginalized families. This gives four categories: 1. A: Children that reproduce social marginalization, 1. B: Children who break the pattern of social marginalization, 2. A: Children that reproduce middle class status, and 2. B: Children who become socially marginalized despite their middle class upbringing. 
Table 6.1.: Reproduction and production of social status.

\begin{tabular}{|c|c|c|}
\hline & Children inheriting the social heritage & Positive/negative "pattern breakers" \\
\hline $\begin{array}{l}\text { 1. Socially } \\
\text { marginalized } \\
\text { families }\end{array}$ & $\begin{array}{l}\text { A. Reproduction of social } \\
\text { marginalization (reproduction theory) } \\
\text { Children who become socially } \\
\text { marginalized (adults) }\end{array}$ & $\begin{array}{l}\text { Children who break the pattern of social } \\
\text { marginalization and become middle class adults }\end{array}$ \\
\hline $\begin{array}{l}\text { 2. Middle class } \\
\text { families }\end{array}$ & $\begin{array}{l}\text { A. Reproduction of middleclass status } \\
\text { (reproduction theory) } \\
\text { Children who become middle class } \\
\text { adults }\end{array}$ & $\begin{array}{l}\text { B. Negative pattern breaking. Production of } \\
\text { social marginalization } \\
\text { Children who become socially marginalized } \\
\text { despite their middle class upbringing }\end{array}$ \\
\hline
\end{tabular}

Families can, in different contexts or periods in life, become more or less socially marginalized. The categories themselves are thus misleading or illusory, since they are only snapshots and do not show how these positions in society are flexible, dynamic and changeable. Even more importantly, categories serve the observer or the describer more than the object. A student categorized as "at-risk youth" might not think of herself as such or might not feel comfortable with being categorized like that. However, to the professional that uses the category "at-risk", categorizing is believed to serve understandings of the young student and to come up with ideas of how to act.

Instead it is the marginalizing processes themselves we ought to describe in order to better understand what and how marginalization happens. My research has focused in the gaps between these categories. The claim that families are either socially marginalized or middle class is oversimplified.

As with the continuum of inclusion and exclusion where students can be more included or less included, families can experience more or less marginalization and this can change dynamically over time and in both directions. It is not people in the categories that need to be studied, but the processes between categories. This is illustrated by adding the two black boxes in Figure 6.2. It is those marginalizing and exclusionary processes, that I have been studying, namely those that unfold in schoolfamily interactions.

In educational research many researchers talk about the black box of schools (Rasmussen et al., 2015, Haslebo \& Lund, 2015 ), to refer to the fact that we know very little about the social processes that take place in schools, both in terms of teaching and learning and in general. With those black boxprocesses in mind, I have further developed the chart to include the black box. (See Figure 6.2.). 
The vertical black box illustrates that children and young people do not suddenly jump from being socially marginalized to being middle class, or vice versa, but that it happens through complicated processes that are invisible to most people. This is exemplified by the horizontal arrow. The horizontal black box illustrates a similar dynamic, namely that children from all kinds of family backgrounds can be more or less marginalized, which the vertical arrow illustrates.

Table 6.2: Reproduction theory and pattern breaking:

\begin{tabular}{|l|l|l|l|}
\hline & $\begin{array}{l}\text { Children inheriting the } \\
\text { social heritage }\end{array}$ & The black box & $\begin{array}{l}\text { Positive/negative "pattern } \\
\text { breakers" }\end{array}$ \\
\hline $\begin{array}{l}\text { Socially } \\
\text { families }\end{array}$ & $\begin{array}{l}\text { Children who become } \\
\text { socially } \\
\text { marginalized/vulnerable }\end{array}$ & & $\begin{array}{l}\text { Children who break the } \\
\text { patterns of socially }\end{array}$ \\
& marginalization and \\
\hline Middle class & $\begin{array}{l}\text { Children who become } \\
\text { families }\end{array}$ & & become middle class \\
& middle class adults & & Children who become \\
& & & socially marginalized \\
& & & despite their middle class \\
& & & upbringing \\
\hline
\end{tabular}

Long-term social processes, that is, repeated interactions, can either pull in the direction of marginalization (exclusion) or integration (inclusion) and are played out in schools, as in every other social system. The situation is misunderstood, if we think that children and youngsters suddenly jump from one box to another. However, from research in positive pattern-breaking we know that one strong relationship can move a young person from the category "socially marginalized" to the category "middle class" (Ejrnæs, 2011). We also know that half of socially marginalized youth are brought up in middle class families, and were moved from this category to the category of being marginalized. We just do not know how it happens.

The problem here is that we know very little about the processes that are involved, for example, which processes work in the family and which work elsewhere, and how these effects operate on each other, for example, in schools. 
One pivotal question that research has not yet settled concerning social marginalization is the question of what is cause and what is effect. It is assumed that families most affected by social and psychological problems are characterized as vulnerable or socially marginalized, and then they meet the welfare institutions where these problems show up. But it could just as well be the other way around. A family may be engaged with the welfare institutions in a way that causes social and psychological problems, which over time develop into social marginalization. As outlined above these are complex processes that are difficult to capture. Discovering and investigating such an opposite linearity has been hindered by the traditional research perspective typically characterized by a pathogenic approach to the families and a salutogenic approach to the welfare institutions (Elsborg, Hansen \& Hansen, 1999). A salutogenic approach refers to health-promoting (salus and genesis) and a pathogenic approach refers to disease-promoting (pathos and genesis). It is most likely that the basic pathogenic perspectives on families maintain the families as problem-owners and indemnify welfare institutions from their share of responsibility for the interactions by which they invite both resourceful and less fortunate families into collaboration.

Instead, what is required in order to be able to listen to and understand processes of marginalization and exclusion is to apply a salutogenic approach to the families and an exploratory approach to the welfare institutions, in this case the schools (Elsborg, Hansen \& Hansen, 1999). This is what I have attempted to do in this study. Listening to parents' accounts has given an insight into the invisible social exclusionary processes of students and parents happening in school.

\section{The need to rethink exclusion and inclusion}

The prevailing understanding of exclusion and inclusion has reached its limits. Thinking of inclusion as a physical enrolment in normal/general educational settings is not helpful for discovering how exclusion is in fact created fluently and dynamically by the positioning created in interactions. The fixed understanding of inclusion as physical presence makes invisible inclusion and exclusion having to do with ways of thinking and ways of communicating and relating. What is done and said determines whether a process becomes inclusionary or exclusionary. What people say and think thus create social worlds. To understand this is important in order for school professionals to deal with interactive troubles without excluding somebody. 


\section{The need to rethink dealing with conflict and bullying}

The analysis shows that school professionals lack methods or approaches for responding to conflict or bullying. Within the dominant individual-, problem- and deficit thinking, school professionals strive to do their best. Yet their practices unintentionally marginalize and exclude students. Rituals of individual blame and spirals of exclusion are repeated. The need for methods to successfully address interactive troubles is evident. School professionals seem to have very little knowledge of what to do when they encounter interactive troubles. The consequences are most unwanted and contradictory to the purposes of education. There is a need to rethink the ways that schools respond to interactive troubles such as bullying, conflict and the like. In developing such methods, it is utterly important to design practices that are inclusionary, relational, restorative, invitational, responsive, and dialogic and that take into account the becoming of students and of social worlds.

\section{The need to rethink school-family-collaboration}

When students find themselves in interactive troubles, school-family collaboration is put under pressure. Frequently, parents are considered difficult, problematic, and needing to accept the problem story of their child. Current practices are not fruitful for either party, and it is evident that rethinking school-family-collaboration is needed. While rethinking this relationship it is important to make room for reciprocal, respectful, appreciative, and exploratory approaches. What is shown in the analysis is that parents are resourceful, reflective and eager to find ways for the school to help the students. These parents are legitimately entitled to be invited into the dialogue as equal and respected contributors. Rethinking school-family-collaboration on these lines would pave the way for understanding how parents' offerings and contributions to problem-solving and dealing with interactive troubles are legitimate and pivotal resources for inclusionary practices.

\section{The need to rethink teachers' competencies}

Exclusionary processes evolve unintendedly and contradict the wishes of all stakeholders. Parents feel marginalized, accused and silenced. It is mysterious how this is not discovered by school professionals. What would it take for them to see and hear the pain and agony these practices produce for students and parents? School professionals could benefit from knowing how to conduct responsive, 
dialogical and restorative practices, that do not only involve multiple and diverse voices, but also take into account students' processes of becoming somebody. The prerequisites for successfully responding to interactive troubles are (1) listening and valuing various voices, (2) being responsive and willing to learn, (3) knowing how to move forward together, (4) and mediating to restore the relationships that have been broken or are threatened. Such competencies are required in order for school professionals to create inclusionary processes in dealing with interactive troubles. In teacher training it is time to set center stage these competencies to conduct inclusionary ways of interacting.

\section{Implications for practice}

This study made clear the importance of engaging students and parents in interactions that are not exclusionary. The task for school professionals is to design interactions to enable students to become somebody, while also effectively addressing the reported problem and finding ways to resolve it. The overall question is how inclusionary practices that deal with interactive troubles can be designed.

\section{What could be different?}

As elaborated in chapter 5 in the analysis of the first story, each step in the exclusionary process is a moment of choice and, therefore, a potential spin-off into another and perhaps more inclusionary process. Many alternative actions are possible and had the school professionals chosen to do differently, the course of events would have developed differently and the possibility of the school professionals creating a process of inclusion much more likely. In White's terms, the alternative options are absent, but nevertheless implicit (White, 2007). According to White something is present, when you see its effects, but there is always also something else there that is absent. For example, contextualizing the interactions what is present is 'the appointing of the student as the problem'. The absent then is NOT to appoint the student as the problem. If the student was NOT appointed as the problem, what might then have happened? What might have happened instead is the absent but implicit.

Exclusion is the end-result in each of the stories. Acting differently presupposes replacing the assumptions driving the exclusionary spiral with opposing assumptions. How might we identify these opposing assumptions? One way is to imagine inclusion as the end-result and then go back from there step by step. 
In the following I shall do that, beginning with step 6 in which the end-result would be inclusion. This would mean conducting the interaction so that the parents were NOT forced to move their child to another school. The fifth step in the backward process would be to focus the dialogue so that it does NOT become a dispute and a family-school conflict. Step 4 would involve NOT positioning the family as problematic and NOT exporting the responsibility for resolving the matter to the parents. Step 3 then would be NOT to ignore, devalue or silence parents and students perspectives. Step 2 would be NOT to present and substantiate the problem descriptions of the student. Step 1 then would be NOT to appoint the student as the problem, but to contextualize the interaction differently.

Following these steps of what NOT to do gives a picture of how not to create an exclusionary process. Yet, questions of how to create better social worlds through responding to interactive troubles in inclusionary ways are not answered. The next sections will explore this further.

\section{Creating better social worlds with spirals of inclusion}

There are numerous ways in which the interactions could have been different. The concept of bifurcation points (Pearce, 2007) pays attention to 'moments of choice and moments of change'. A clear example of this is offered in the first story, where the school professionals could have let the student speak, when he raised his hand. As well, they could have initiated a round of the table, letting everyone speak. They could have explored and interviewed the student around his story of being bullied. Since the possibilities are numerous and endless, I will continue to focus on the six steps outlined in the spiral, but with emphasis on what TO DO, instead of what NOT to do. Each step is a choice made by the school professionals, and with the purpose of creating an inclusionary spiral, the aim is to strengthen the collaboration between families and schools and ultimately to support the process of becoming somebody of the student. Let us take a look at the six steps in an inclusionary process around responding to interactive troubles:

\section{Contextualizing the interaction around resolution and exploring ideas to help the student(s).}

From a relational viewpoint, the school professionals might contextualize the interaction around resolution and explore how to help students, focusing on the group of students and their relationships in context with each other, teachers, the school and the wider community. The school professionals might have invited students and parents into a dialogue around hopes and dreams for the future to identify what is important in order to find ways of going on together. 
2. The family is invited into an appreciative inquiry of hopes, wishes, and ideas of what the school might do to help the student(s).

The school professionals might have focused on listening to students' and parents' accounts, together with others' perspectives. They could search for counter stories and more nuances, for example, exploring the strengths and potentials of students. There are always things to learn and more voices can enrich the mutual understanding. In addition, being listened to and valued gives rise to feeling appreciated and worthwhile, which is of highest concern for the school professionals.

3. Family accounts, stories and perspectives are welcomed, explored, valued and listened to.

The school professionals might have respected and valued the student's and the parents' attempts and wishes to speak, and explored and integrated their perspectives on the matter. By paying attention, school professionals could have appreciated and valued the family's perspectives, worries, wishes and suggestions.

4. The Family is positioned as knowledgeable, responsible and willing to collaborate. The responsibility for resolving the matter is maintained within the school arena.

Had the school professionals explored the wishes of the student and the parents and listened to what they said, they might have learned more. Learning about resources, skills, wishes, potentials, and experiences of the student might in addition to a better understanding of the student, have provided school professionals with knowledge about how to help the student. By listening, taking them seriously, exploring and valuing the family's contributions, the school professionals would position the family as resourceful and knowledgeable - in stark contrast to positioning them as "the problem-family".

5. The discussion is focused on 'what the school can do to help the student(s)' and on strengthening the collaboration and relationships, so that it does NOT become a clash of stories

The school professionals might have initiated a two-way dialogue based on the students' story of 'being bullied/lonely/afraid in school' and focused on resolutions and interventions to help the group of students. A huge part of helping is to listen, value and learn, in order to further develop a collaborative relationship. They might not have turned the conversation into a family-school-conflict, but focused on a mutual exploration of the possibilities of the school to sort things out, whilst taking the responsibility for interactive troubles in schools. 


\section{Respectful ways of going on together are collaboratively agreed on. Maintaining an open and respectful communication. Inclusion is the result.}

The school professionals might have taken into account the jeopardizing of the student's belonging to the school, and his wishes to be treated as an included and worthwhile contributor. They might have conducted the meeting in a friendly and caring manner that establishes and strengthens a collaborative relationship with a shared higher moral purpose of creating better social worlds. They might have talked about the future and the dreams of the student. They might have let him feel that he was worthy of respect and was 'somebody' who deserved to be included in the process. Such a process is conducted by the school around what the school can do to help the student(s), and illustrated in the figure 6.1. below.

Figure 6.1; The spiral of inclusion.
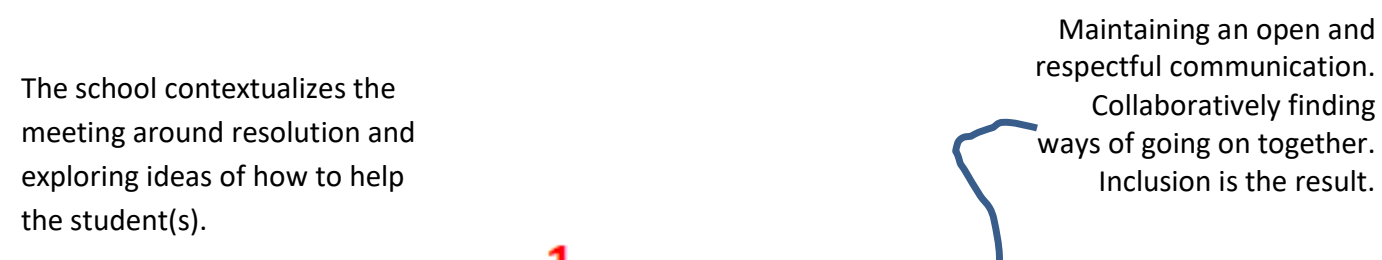

The discussion is focused on 'what the school can do to help the student(s)' and on strengthening the collaboration and relationships, so that it does NOT become a dispute/clash of stories and a familyschool conflict.

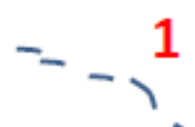

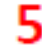

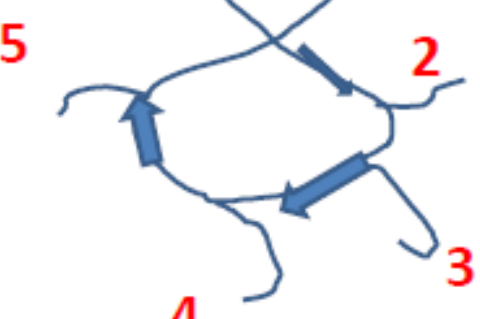
4

The Family is positioned as knowledgeable, responsible and willing to collaborate. The responsibility for resolving the matter is maintained within the school arena.
The family is invited into an appreciative inquiry of hopes, wishes, and ideas of what the school might do to help the student(s).

Family accounts, stories and perspectives are welcomed, explored, valued and listened to.

In this way, the school focuses on proceeding in ways that strengthen the collaboration and relationships by continuously involving students' and parents' voices in the continuous adjustments and improvement of the learning community for all students. Such a course of events would have given the 
family (and the school professionals) a much more uplifting, constructive and productive meeting. The responsibility of the school for finding resolutions of interactive troubles in schools would have led the school professionals into an inquiry into their own practices and thereby made the basis for development and improvement. The conditions for the student to become somebody would have been improved and the restoration of the student's belonging to the school community much more likely.

In the following section, I shall compare the different choices that school professionals face when designing interactions with parents around interactive troubles.

\section{Choices in dealing with interactive troubles}

By now, it is clear that there are various ways of responding to interactive troubles, some more or less exclusionary or inclusionary. What makes the difference are the actual actions and communication performed - that is the basic assumptions that are allowed to dominate and guide actions and ways of thinking. I wish to make clear that school professionals have choices, and that they can choose to conduct either exclusionary or inclusionary interactions. Table 6.3 compares these choices/actions, emphasizing that they are moments of choice and moments of change.

Table 6.3. Different choices in exclusionary and inclusionary practices

\begin{tabular}{|c|c|c|}
\hline Moments of choice & Exclusionary practices & Inclusionary practices \\
\hline $\begin{array}{l}\text { How to } \\
\text { contextualize the } \\
\text { interaction? }\end{array}$ & $\begin{array}{l}\text { Around the student and/or } \\
\text { the family as the problem }\end{array}$ & $\begin{array}{l}\text { Creating a respectful relationship, resolution and } \\
\text { exploring ideas for how to help the student(s). }\end{array}$ \\
\hline $\begin{array}{l}\text { How to address the } \\
\text { problem? }\end{array}$ & $\begin{array}{l}\text { Presenting, repeating and } \\
\text { substantiating the problem } \\
\text { story }\end{array}$ & $\begin{array}{l}\text { Inviting the family into an appreciative Inquiry of hopes, } \\
\text { wishes, and ideas of what the school might do to help the } \\
\text { student(s). }\end{array}$ \\
\hline $\begin{array}{l}\text { How to respond to } \\
\text { parents' and } \\
\text { student's voices? }\end{array}$ & $\begin{array}{l}\text { Rejecting, denying and } \\
\text { silencing them }\end{array}$ & Welcoming, listening, exploring and valuing them \\
\hline $\begin{array}{l}\text { How to position } \\
\text { parents? }\end{array}$ & $\begin{array}{l}\text { Exporting the problem into } \\
\text { the family. }\end{array}$ & $\begin{array}{l}\text { Positioning parents as knowledgeable, responsible and } \\
\text { willing to collaborate. The responsibility of resolving the } \\
\text { matter is maintained within the school arena. }\end{array}$ \\
\hline $\begin{array}{l}\text { How are the } \\
\text { options for action } \\
\text { formed for the } \\
\text { parents? }\end{array}$ & $\begin{array}{l}\text { The situation is turned into } \\
\text { an ultimatum; either the } \\
\text { parents become docile } \\
\text { toward the positioning and } \\
\text { problem story, or ultimately } \\
\text { they can find another school }\end{array}$ & $\begin{array}{l}\text { The dialogue is focused on 'what the school can do to help } \\
\text { the student(s)' with regards to strengthening the } \\
\text { collaboration and relationships, so that it does NOT } \\
\text { become a family-school conflict }\end{array}$ \\
\hline $\begin{array}{l}\text { What is the } \\
\text { outcome of the } \\
\text { exchange? }\end{array}$ & $\begin{array}{l}\text { Exclusion. The family is forced } \\
\text { to find another school. }\end{array}$ & $\begin{array}{l}\text { Inclusion. Maintaining a strengthened collaborative and } \\
\text { respectful relationship, where parents and students are } \\
\text { positioned as respected, worthwhile, resourceful and } \\
\text { knowledgeable, in order to find ways of solving the } \\
\text { problem that take into account the becoming somebody } \\
\text { of the student. }\end{array}$ \\
\hline
\end{tabular}




\section{Moments that matter}

On a practical level it is important to identify the moments that matter in the course of events that create an inclusionary spiral. This is helpful for school professionals in their planning and conducting of school-family interactions around interactive troubles. As elaborated, moments that matter are, in fact, moments of choice and change. Opting for inclusionary practices leads to a six step model for school-family interactions in dealing with interactive troubles, as illustrated in Table 6.3. In chapter 5 we saw that specific basic assumptions led to the exclusionary practices. These were individual, problem and deficit assumptions. Logically, it is possible to create inclusionary processes by using a different way of thinking. When specific kinds of communication create specific positions and options for action, other kinds of communication must create other positions and options. However, they might have become inclusionary, had the school professionals acted differently in each moment of choice. Therefore, it is of great interest what basic assumptions lie behind inclusionary practices and drive an inclusionary spiral.

\section{Assumptions in inclusionary interactions}

The first assumption is that any given problem is relational, contextual and co-created amongst participants in a system, and thus can be understood in multiple ways. Therefore, it is pointless to seek one true description. "What is real" can be seen in many different ways according to viewpoint, perspective, relations, positions, and contexts. The idea of a universal real world 'out there' is replaced with the idea of multiverse in which there are many versions of the truth. The urge to make problem descriptions that appoint the student as the problem is replaced with an urge to take into account the becoming somebody of the student and perform inclusion, which better fits the moral purpose of schooling. Hereby a process starts with inviting people into a shared, polyvocal and appreciative inquiry around desired futures and preferred actions on how to create better social worlds.

The second assumption is that people (including parents and students) have resources, skills and competencies, and are willing to collaborate, to share ideas and to have an impact. Therefore, school professionals might engage with parents and students to co-create images of shared learning potentials and actions and positive resources in the system, needed to create a better social world for the involved.

The third assumption is that what makes a person is not an inner core identity, but is constituted by relationships, positions, contexts and discourse. A student that struggles in school can be functioning 
well at home, in the leisure club or at football training. Instead of having to reach "a common picture", which means the "same picture", the conversation would focus on working together to put words to many different facets of a student's ways of operating - especially focusing on the resourceful ones which are the ones needed for improvement. What constitutes a person are also the narratives about him. Therefore, teachers must pay very careful attention to the stories they tell about students and how these stories invite students into being.

This counts for parents as well, because they also become who they are positioned as. If they are invited into a dialogue as resourceful and experienced contributors with ideas to improve the conditions for and interactions with the child, they will most likely act accordingly. Parents act differently in different situations depending on how they are met. One could say that parents are largely constructed by the way they are invited into collaboration. This assumption has major implications for the organization and conduct of school-family interactions, where speaking time is distributed evenly, and the language used is less authoritative and more exploratory.

The fifth assumption is about parents' obligations to the school. When it is assumed that a child behaves differently depending on context and relationship, it becomes impossible for parents to provide a "clean and teaching ready" child. A "clean and teaching ready" child is a child that successfully meets all the school rules in every situation regardless of circumstances and without their parents being present. But the child is engaged in many relationships outside and inside the school - with teachers and classmates - and his or her behavior is not determined by his or her inner personality, nor by the upbringing of the parents, but also by the relationships and interactions in school. Parents can support school professionals by sharing their resources and experiences with their child and co-creating ideas for how to motivate and collaborate with their child. They can also contribute by conveying the views and perspectives of their child on school practices to inform teachers and to offer recognition for teachers' work, when appreciated by the child.

The sixth assumption is that "the right way" to solve a problem is inherently an ethical and moral question. What is done needs to be questioned in terms of what it creates and how it influences relationships and the conditions for the student to become somebody A problem solving process needs to be polyvocal and co-created and to strive towards better social worlds. For the school it is a question of responding to interactive troubles in ways that are respectful, responsive, restorative, inclusionary and fulfilling of potentials. 


\section{An alternative to the deficit discourse?}

The assumptions just elaborated are all characterized by a shared focus on relationships rather than on individuals. They pay attention to how people become and are influenced by the relationships they engage in, and take into account how actions and communication shape and transform relationships for better or worse. Secondly, they focus on resources and possibilities instead of on problems. Instead of an analysis of problems, they seek to engage in a collaborative inquiry of differing perspectives, experiences, hopes, desired futures, and competencies. Finally, they take into account the ethical obligation to find ways of going on together that do not separate and stigmatize, but seek resolution and restoration. They are relational, resource and resolution-focused assumptions.

Even though these assumptions hold the promise of leading to an inclusionary spiral, they were not acted upon in any of the stories. Why not? Are they not known to school professionals? Are they known, but just not put into practice as often as the deficit assumptions? Or is it because they require specific competencies as yet unfamiliar to school professionals? And if so, what competencies do they specifically require? It would be too exhaustive a task to go into answering these questions here. However, I would recommend both looking at the competencies of school professionals as well as the significance of different school cultures in the search for answers. In the following, I shall briefly outline what can - based on this study - be said about required skills of the school professionals.

In the inclusionary process school professionals contextualize, listen, focus, value, explore, invite, and the like. It is assumed that most professionals are able to do such things. However, the traditional way of dealing with interactive troubles does not set the stage for acting like this. Again, what is needed is perhaps not just listening, but a certain kind of listening that was explained in chapter 3. Elaborated here, it is a question of what governs the selection in listening. Rowan (1996) points out, that even though marginalized youth do try to speak, they cannot be heard 'from outside of the deficit discourse'. This refers to the listener being 'deaf' to what is being said, meaning that what they hear is interpreted in a certain deficit way. The assumptions at play (epistemology) govern the selection of what is possible to hear. Thus, being able to offer emergent or double listening (White, 2007) is a highly recommended skill for school professionals in dealing with interactive troubles.

Another important competence is to pay attention and explore opposing and different perspectives, which suggests being curious and not having a fixed mindset or presumption about the problem. It requires asking appreciative and exploratory questions and a willingness to learn, change perspective, remain open and creative. A third pivotal competence is valuing, which requires appreciative and communication skills, as well as the skill to discover things that can be valued. What is 
valued can be integrated in the communal agreement of what to do to try help students. Integrating students' and parents' voices makes explicit how other views and perspectives are useful and can be put into action. The last important competence to include here is speaking with relational responsibility and using a non-stigmatizing language.

Having identified the assumptions that drive inclusionary practices and briefly outlined some required competencies for conducting such practices, it is worth asking whether there exist school approaches to dealing with interactive troubles that are based on these assumptions. The uplifting answer is yes. In the next section, I shall briefly present some of these approaches.

\section{Responding to interactive troubles}

School professionals CAN respond to interactive troubles in ways that offer students and parents positions with dignity, voice, and agency, and that invite them into forms of relating in which students can become somebody. Such ways of responding to interactive troubles imply an advanced professionalism, which has been in development for several decades in various educational settings around the world. In the following sections I shall briefly present a couple of ways.

\section{Restorative Practices}

Social constructionist efforts to respond to interactive troubles in school are commonly referred to as restorative or relational practices (Drewery \& Winslade, 2003; Kecskemeti 2004; Williams \& Winslade, 2012). These approaches have developed in regards to dealing with bullying and conflict resolution in order to establish an inclusionary learning environment for all students, without resorting to a punitive and marginalizing approach (Mirsky \& Korr, 2014). What these practices do is to address problems rather than blame. There is compelling research support for the efficacy of restorative practices (Drewery \& Winslade, 2003; McGarrigle, 2005; Kecskemeti, 2004), as well as other relationship focused approaches such as narrative mediation practices and undercover anti-bullying teams (Winslade \& Williams, 2012, p. viii; Williams, 2010). A third and fourth branch to mention here are CosmoKidz (Haavimb, 2015) and strength-based pedagogy and education (Lund \& Haslebo, 2015). As an umbrella concept, restorative practices is a term for specific practices that make it possible for school professionals and students to effectively deal with interactive troubles in ways that strengthen relationships, enhance relational and communicational skills and give hope for the future. 
These approaches spring from various inspirational sources and developed in various countries at a similar time. One source is restorative justice (Amstutz \& Mullet, 2005; Zehr, 2002; 2004; 2005) that developed with the purpose of breaking the school-to-prison pipeline so that fewer young people were lost to criminality and a life on the edge of or outside community. Restorative justice as it emerged in Australia and New Zealand (British Colombia Ministry of Education, 1999; Shaw; 2007) was developed with great inspiration from both Maori and Aboriginal cultures. Due to positive results restorative justice spread within a few years to many parts of the world and to many different areas from social work, education, criminal prevention and so on (Drewery \& Winslade, 2003). Jansen and Matla (2014) argue that restorative practice is a relational approach to school life grounded in beliefs about equality, dignity, mana and the potential of all people.

In the late twentieth century the New Zealand Ministry of Education launched two projects around restorative conferencing in schools (Adams, Cronin-Lampe, Cronin-Lampe, Drewery, Jenner, Macfarlane, McMenamin, Prestidge \& Winslade, 2003). The aim was to reduce the high number of expulsions and exclusion of Maori children in New Zealand schools. A research team from University of Waikato was set to conduct the projects that today are considered as a starting point of restorative practices (Drewery, 2007). The New Zealand Ministry of Education wanted the research team to work on the principles of restorative justice, now that this approach had shown such positive results in relation to breaking the prison pipeline in crime prevention activities, and especially in relation to getting both victim and violator well ahead in life with new skills. Summing up, the principles were:

- Restoration, not retribution, punishment, consequences or upbringing

- Relationship, not individuals

- Responsibility to the victims, not facing the authorities

- Includes more voices rather than isolating the individual

(Adams et al. 2003, p. 4)

The research team from Waikato University was inspired by social constructionist ideas with deep roots in narrative theory. Interestingly, the principles for restorative practices in schools match quite smoothly with the basic assumptions within relational-, resource- and resolution-thinking outlines in this study. Furthermore, restorative practices are conducted with the purpose of schools taking responsibility for the process of becoming of students regardless of the role they take in interactions (Renn, S. n.d.). 


\section{Narrative mediation}

Narrative mediation was developed by Winslade \& Monk (2000) on the basis of narrative counselling theories. As a practice in schools narrative mediation aims to invite parties in a dispute or conflict to come together in a mutual sharing of perspectives in order to build understanding and accept of one and another (Winslade, 2006; Winslade \& Monk, 2008; Winslade \& Williams, 2012). In the hands of a trained school professional, a school counselor or a mediator narrative mediation offers an effective conflict management approach with attention to the design of processes for constructively handling differences and sometimes outbreaks of conflict (Winslade \& Williams, 2012). It has proved to be highly effective in addressing conflicts and interactive troubles in different educational settings. As a restorative practice, narrative mediation in schools put emphasis on relationships and the co-creation of peaceful and respectful ways of going on together.

\section{Undercover anti-bullying teams}

Undercover anti-bullying teams were developed by the school counselor Michael Williams (2010) to use when a bullying-story has become established, and thus when certain students are already positioned as bully, victim and the bystanders/the others. It has proven highly effective in transforming bullying patterns into inclusionary communities (Drewery, 2007; Jansen and Matla (2014; Uppal, 2012). Winslade and Williams (2012) describe in their book a wide range of approaches and methods of dealing with conflicts and bullying in ways that strengthen good friendships and an inclusive learning environment in schools. The method is also described in Danish (Haslebo \& Lund, 2014; Williams, 2012). The approach aims to offer students that are positioned as bullies new positions as mates with a special mission: to cherish, care for, give recognition to, and show respect for the person or persons positioned as victims. As one position changes, so do the others, and thus the bully story. Without bullies, there is no bullying story. In Australia, New Zealand, USA and Canada, where the method is most used, it is common to have a school counselor for students to contact with issues such as bullying. The student counselor can then suggest the teacher to try out undercover anti-bullying teams. In Danish schools it is not common to have such school counsellors, but an AKT-teacher or another school professional could take on the task if they were trained to lead the process. The process runs in five phases; a) recognition of the victim, b) recruitment of secret agents, c) the design of the specific plan, d) discovery and articulation of progress and c) celebration of success. It typically takes 
two-three weeks to go through the five stages. The method has been evaluated to be successful in transforming the bullying behavior and create respectful and helpful relationships

(Winslade \& Williams, 2012).

\section{CosmoKidz}

The third restorative practice included here is CosmoKidz that is an educational approach inspired by CMM-theory designed to help children develop experiences and skills for empathy, respect, positive self-realization, creativity, self-awareness, attention towards the act rather than reaction, and communicating in a way that supports good relationships and better social worlds (Haavimb, 2015; Pearce, 2014c). It aims to teach and train relational, social and communication skills to children in kindergarten and schools. It has shown remarkable results in Norway and the US, not only in terms of improved student learning and agency, but also in terms of teachers' learning, commitment and performance, which was a surprise to the participating schools (Pearce, 2014a; 2014b). What was found in the evaluation was a reduced level of conflict, more mutual understanding, and better solving of interactive troubles. The skills that students learned made a difference to the families as well, where parents learned from their children new ways of engaging and solving problems.

\section{Appreciative Inquiry pedagogy and education}

Appreciative inquiry and strength-based pedagogy has developed in parallel and in different parts of the world (Cooperrider \& Srivastva, 1987; Hauger, 2015; Mæland \& Hauger, 2008; Whitney \& Trosten Bloom, 2003). I shall just offer one example here from Norway of how appreciative inquiry is used to create inclusionary learning school communities. The school in Norway was established to offer "at-riskyouth" an educational setting in which they could recover, gain self-confidence, academic skills and community participation after having dropped out of (been excluded from) public schools, and in many cases not having been to schools for a longer period. The number of students has increased year by year, and today 232 students are enrolled in the school. From the yearly report of 2016 it is stated that $87 \%$ are either in education or a job, $73 \%$ is in education, and $91 \%$ of all students is engaged positively in the activities (Mæland, 2017)

After having had years with interactive troubles in various public schools and private life the young people are marginalized, and some of them to severe extents such as being suicidal, self- 
destructive and living life in the margins of society. Being faced with trust, non-judgment, positive expectations, appreciation, inclusionary practices and patience - and learning the skills of appreciative inquiry - the students transform into responsible and capable students with dreams for their future.

The school has not only been widely acknowledged nationally and internationally for its positive and continuous results, but also developed into a knowledge center collaborating with University Colleges and international partners. The interest in this school's practices springs from the fact that it is so successful in re-integrating marginalized and disillusioned young people after they have been failed by public schools and social services. The central thing here is that the practices are also feasible for preventing marginalization from happening in the first place, and therefore public schools are interested in learning how to use appreciative inquiry as a basic pedagogical philosophy.

The different restorative practices outlined here are examples of ways to deal with interactive troubles that do not stigmatize, marginalize or exclude, but instead foster belonging, peaceful coexistence, becoming and inclusion. These approaches are learnable, doable, and feasible, also in Danish schools. They do, however, require a shift in epistemology. Nevertheless, I believe this is possible, and based on my study of schools responding to interactive troubles, I believe that - had the schools known of such restorative approaches and practices - what became school-parent conflicts, social marginalization and exclusion might have instead developed as a polyvocal, respectful learning process around exploring perspectives and co-creation of better outcomes. To this end, relational and restorative practices hold promise for very different and far better futures for students, parents and school professionals.

Having pointed towards basic assumptions within inclusionary practices and outlined the choices school professionals CAN make in dealing with interactive troubles, provides a guideline for school policies, for school professionals in schools, as well as for teacher training, pedagogue training and principal training. As such, this study advocates for opening up the serious call for inclusionary ways of responding to interactive troubles in schools.

\section{Concluding remarks}

Based on a thoroughly examination of the ways that schools in this study responded to interactive troubles, it is possible to conclude that: 
1. Responding to interactive troubles from deficit, problem and individual thinking produces exclusionary processes.

2. Thus, parents and students not yet "at-risk" become marginalized.

3. These processes are happening in school, however invisible to most people.

4. But it does not have to be like this, since other practices that have proven their merits in educational settings, are available.

Thus, there is a serious call for using inclusionary ways of responding to interactive troubles in schools. And not many reasons not to.

School professionals engage in conversations and actions when dealing with conflict and problem behavior in schools based on basic assumptions and dominating discourses. What assumptions and discourses are at play and how school professionals respond - what actions, practices, language and thinking they use - is of great importance to the subsequent events, to how relationships unfold, and, in the end, to the broader school culture itself.

Giroux (1991) argued that some conversations and practices make students and their parents voiceless in particular settings by not allowing them to speak. Roman (1996) and Fine (1994) as well as Winslade and Williams (2012) argued that some students silence themselves out of either fear, or hopelessness or alienation. The data collected for this study suggest that practices in dealing with interactive troubles in schools often silence and eventually exclude students and families.

Students may leave a school for a number of reasons; the family is moving, the student wishes to attend another school that offers other subjects, or wishes to make new friends. Changing to another school can thus be positively motivated and is not always due to negative experiences. But sometimes it is. Unfortunately there is not much available ${ }^{12}$ data in Denmark on this, and it has not been much researched how frequently students change to other schools and for what reasons. But in the cases where changing schools is negatively motivated and the school acknowledges the exclusionary process, the practice of exclusion can become visible. When visible, it is also more likely to be investigated with the chance of learning how to change. Unfortunately, the research literature and the data collected for this study suggests that schools do not seem to acknowledge leaving school based on interactive trouble as connected to failed inclusion, but to various other things, and thereby exclusionary processes remain invisible.

\footnotetext{
${ }^{12}$ Danmarks Statistik possess data that research institutions with a research cooperation agreement can get access to. Others have to pay a substantial amount of money to get access.
} 
Sometimes they are even invisible to the families themselves, if they do not connect what is going on to an exclusionary process, however unpleasant, unwanted, uncontrollable, and painful it was. What they are left with is the experience of being different, problematic, or dissatisfied, but not necessarily objects of an exclusionary process.

In chapter 3 various ways of thinking related to various epistemologies was outlined. Ways of thinking are grounded on basic assumptions about the world, what is truth, what is a problem, and what are the ways of approaching problems. Looking at the communication, positioning and interactions in the stories and understanding how they produced exclusionary processes, it was possible to identify the specific basic assumptions at play. Based on the analysis in chapter 5 the basic assumptions leading to exclusion were identified and compared with the two ways of thinking outlined in chapter 3 . This laid the foundation for me to say that individual-, deficit- and problem-thinking dominates the way schools are responding to interactive troubles, including the way they engage and interact with parents.

Thus, this study is a strong call for reconsidering how to respond to interactional troubles. Reconsidering does not mean abandoning accumulated wisdom, but it does require being prepared to examine how various practices and ways of communicating position students and their families in certain roles. Reconsidering requires an awareness of the differentials of power that pertain in most relationships. Smyth and Hattam (2004) state that what gets said and what gets listened to is always to be understood as marked by unequal power relations ( $p .13$ ). Being sensitive to power involves responsiveness to how emotions, positions, relationships and actions are shaped and formed through and by the communication of those acting out power.

Building on this kind of thinking, Smyth and Hattam explore and map what Sibley (1995) calls "geographies of exclusion". This is his reference to "the human landscape as a landscape of exclusion (p. ix). Like Sibley and Smyth and Hattam I have put center stage the more opaque instances of exclusion. According to Sibley (1995) "these exclusionary practices are important, because they are less easily noticed and so the ways in which control is exercised in society are concealed" (p. ix).

Haslebo and Lund (2014) found that schools are the least likely to want to share stories of how they fail to include and, thereby, unintentionally the exclusion of students and families goes on. Schools do not gather data on these events, nor do they follow up on the families to see how they are doing after their child has left the school. Therefore, a lot of important knowledge and learning opportunities are missed. Unfortunately, it seems that processes in schools leading to exclusion are not commonly acknowledged and exist invisibly for most people. 


\section{Reference list}

Aarhus Universitet (2011). TIMSS undersøgelsen 2011 - En sammenfatning. Retrieved 09.03.2017 http://edu.au.dk/fileadmin/edu/Forskning/Internationale undersoegelser/TIMSS/TIMSS 2011 resume.pdf

Alenkær, R. (2008). Den inkluderende skole. En grundbog. Frederiksberg; Danmark: Frydenlund. Allan, J. (2010). The sociology of disability and the struggle for inclusive education. British Journal of Sociology of Education, 31 (5), 603 - 619. Doi.org/10.1080/01425692.2010.500093

Anderson, G. \& Herr, K. (1994). The micro-politics of student voices: moving from diversity of bodies to diversity of voices in schools. In C. Marshall (Ed.). The new politics of race and gender (pp. 58-69). Washington, DC: Falmer Press.

Amstutz, L. S. \& Mullet, J. H. (2005). The little book of Restorative Discipline for schools. Teaching responsibility; Creating caring climates. Intercourse, PA: Goodbooks.

Apple, M. (1986). National reports and the construction of inequality. British Journal of Sociology of Education, 7 (2), 171- 190 . Doi.org/10.1080/0142569860070205

Apple, M. (1996). Power, meaning and identity: Critical sociology of education in the United States. British Journal of Sociology of Education. 17 (2), 125 - 144. Doi.org/10.1080/0142569960170201

Atkinson, R. \& Flint, J. (2001). Accessing hidden and hard-to-reach populations: Snowball research strategies. Social Research Update, Issue 33. Retrieved 16.11.2016 from http://sru.soc.surrey.ac.uk/SRU33.pdf

Austin, J. L. (1975): How to do things with words. Cambridge, MA: Harvard University Press. Avalos, M. \& Winslade, J. (2010). Education as a 'line of flight'. Explorations: An E-Journal of Narrative Practice, 1, 70-77. Adelaide, AU: Dulwich Centre Foundation.

Ball, S., Davies, J., David, M. \& Reay, D. (2002). 'Classification' and 'judgment': Social class and 
the 'cognitive structures' of choice in higher education. British Journal of Sociology of Education, 23 (I), 51-72.

Bakhtin, M. M. (1981). The dialogic imagination: Four essays by M.M. Bakhtin. Austin, TX: The University of Texas Press.

Bakhtin, M. M. (1986). Speech genres and other late essays. Austin. TX: University of Texas Press.

Bang-Larsen, B., Bang-Larsen, O., \& Rasmussen, T. (2001). Classroom Management. Frederikshavn; Danmark: Dafolo.

Barba, F. (2012). The effectiveness of peer strategies to counter bullying: Undercover anti-bullying teams. Unpublished Masters degree project. San Bernardino, CA: California State University, San Bernardino.

Barber, M. \& Fullan, M. (2005). Tri-level development: Putting systems thinking into action. Education Week, 24 (25), 32 - 35.

Barber, M., Mourshed, M. \& Chijioke, C. (2010). How the world's most improved school systems keep getting better. McKinsey Post Report. Retrieved 01.03.2017 from http://mckinseyonsociety.com/downloads/reports/Education/How-the-Worlds-MostImproved-School-Systems-Keep-Getting-Better Download-version Final.pdf

Barry, B. (1998). Social exclusion, social isolation and the distribution of income. CASE paper Centre for Analysis of Social Exclusion CASE/12. London, UK: London School of Economics. https://core.ac.uk/download/pdf/93935.pdf (retrieved August 2016).

Bauman, Z. (2001). The individualized society. Cambridge, UK: Polity Press.

Baumeister, R. F. \& Leary, M.R. (1995). The need to belong: Desire for interpersonal attachments as afundamental human motivation. Psychological Bulletin. 117, 497-529. Doi.org/10.1037/0033-2909.117.3.497

Bavelas, J., Coates, L., \& Johnson, T. (2000). Listeners as co-narrators. Journal of Personality and 
Social Psychology, 79 (6), 941-952. Doi.org/10.1037/0022-3514.79.6.941

Bava, S. (2001). Transforming performances: An intern-researcher's hypertextual journey in a postmodern community. (Unpublished doctoral dissertation). Blacksburg, VA : Virginia Polytechnic Institute and State University.

Baviskar, S., Dyssegaard, C. B., Egelund, N., Lausten, M., Lynggaard, M. \& Tetler, S.

(2013).Dokumentationsprojektet: Kommunernes omstilling til øget inklusion. Marts 2013.

Institut for Uddannelse og Pædagogik (DPU), Aarhus Universitet. SFI. Det Nationale

Forskningscenter for Velfærd. Retrieved 01.03.2017 from

http://edu.au.dk/fileadmin/edu/Udgivelser/E-boeger/Ebog -

Kommunernes omstilling til oeget inklusion.pdf

Baviskar, S. Dyssegaard, C.B., Egelund, N., Lausten, M. \& Lynggaard, M. (2014).

Dokumentationsprojektet: Kommunernes omstilling til øget inklusion pr. marts 2014. Aarhus Universitet, Institut for Uddannelse og Pædagogik (DPU) og SFI. Det National Forskningscenter for Velfærd. Retrieved 01.03.2017 from

http://edu.au.dk/fileadmin/edu/Forskning/SILO/Kommunernes omstilling til inklusion 2014 - web.pdf

Bellah, R. N., Madsen, R., Sullivan, W. M., Swidler, A., \& Tipton, S. M. (1985). Habits of the heart. Berkeley, CA: University of California Press.

Benjaminsen, L., Andrade, S. B., Andersen, D., Enemark, M.H. \& Birkelund, J. F. (2015).

Familiebaggrund og social marginalisering i Danmark. En registerbaseret kortlægning. Købehavn, Denmark: SFI.

Bentz, V. M., \& Shapiro, J. J. (1998). Mindful inquiry in social research. Thousand Oaks, CA: Sage. Bergson, H. (1998). Creative evolution. Mineola, NY: Dover .

Bezzina, M. (2007). Moral purpose and shared leadership: The leaders transforming learning and 
learnes pilot study. ACEReSearch, Australian Council for Educational Research. The Leadership Challenge - Improving learning in schools. Retrieved 01.03.2017 from http://research.acer.edu.au/cgi/viewcontent.cgi?article=1013\&context=research conference $\underline{2007}$

Biesta, G. J. J. (2014). The beautiful risk of education. London, UK: Taylor \& Francis.

Bochner, A. (2002). Perspectives on inquiry: III. The moral of stories. In M. Knapp \& J. Daley (Eds.), The SAGE handbook of interpersonal communication ( ${ }^{\text {rd }}$ Edn.), (pp. 73-101). London, UK: Sage. Bochner, A.P. \& Ellis, C. (Eds.) (2004). Ethnographically speaking: Ethnography, literature and aesthetics. Walnut Creek, CA: Alta Mira Press.

Bodiford, K. \& Camargo-Borges, C. (2014). Bridging research and practice: Illustrations from Appreciative Inquiry in doctoral research. Al Practitioner: International Journal of Appreciative Inquiry. August 2014. 16 (3). 9-12. DOI.org/10.12781/978-1-907549-20-5

Bojer, M., Roehl, H., Knuth, M., \& Magner, C. (2008). Mapping dialogues. Essential tools for social change. Chagrin Falls, $\mathrm{OH}$ : Taos Institute.

Boot, T. \& Ainscow, M. (2000). Index for inclusion. Developing learning and participation in schools. Bristol, UK: CSIE. Retrieved 17.02.2017 from http://www.eenet.org.uk/resources/docs/Index\%20English.pdf.

Bourdieu, P. (1998). Practical reason: On the theory of action. Cambridge, UK: Polity Press. Brace-Govan, J (2004). Issues in Snowball Sampling: The lawyer, the model and ethics.

Qualitative Research Journal, 4. 1: 52. Retrieved from 01.03.2017

http://search.informit.com.au/documentSummary;dn=879742197922293;res=IELHSS.

Brinkmann, S. (Ed.) (2010). Det diagnosticerede liv - sygdom uden grænser. Århus, Danmark: Forlaget Klim.

British Colombia Ministry of Education, 1999. Focus on suspension: A resource for schools. 
Vancouver, Canada: Author, Special Programs Branch. RB0079.

Bronwyn, D. (2008). Re-thinking 'behaviour' in terms of positioning and the ethics of responsibility. In A. M., Phelan \& J., Sumsion (Eds.): Critical readings in teacher education, provoking absences. Rotterdam: The Netherlands: Sense.

Browne, K. (2005). Snowball Sampling: Using social networks to research non-heterosexual women. International Journal of Social Research Methodology, 8 (1), 47-60.

DOI: $10.1080 / 1364557032000081663$

Brown, P. (1997). Cultural capital and social exclusion: Some observations on recent market trends in education, employment and the labour market. In A. Hasley, H. Lauder, P. Brown \& A. Wells (Eds.), Education culture, economy, society. (pp. 736 - 749). Oxford, UK: Oxford University Press.

Bruun-Schmidt, M. (2014). Dårlig trivsel får mange børn til at skifte til en ny skole. Politiken, 5. april, 2014. Retrieved 05.04.2014 from http://politiken.dk/indland/uddannelse/ECE2255905/daarlig-trivsel-faar-mange-boern-til-atskifte-til-en-ny-skole/

Bruner, J. (1990). Acts of meaning. Cambridge, MA: Harvard University Press.

Buchert, L. (1995). The concept of education for all: What has happened after Jomtien? International Review of Education/Internationale Zeitschrift für Erziehungswissenschaft/Revue Internationale de l'Education, 41 (6), 537-549.

Burchardt, T., Le Grand, J. \& Piachaud, D. (2002). Degrees of exclusion: developing a dynamic multidimensional measure. In J. Hills, J. Le Grand \& D. Piachaud (Eds.), Understanding social exclusion (pp $30-43)$. Oxford, UK: Oxford University Press,.

Burkitt, I. (1999). Bodies of thought: embodiment, identity and modernity. Trowbridge, Wiltshire, UK: Sage. 
Burr, V. (1995). An introduction to social constructionism. London, UK: Routledge.

Burr, V. (2003). Social constructionism ( $2^{\text {nd }}$ Edn.). London, UK: Routledge.

Cammarota, J. \& Fine, M. (Eds.) (2008). Revolutionizing education: Youth participatory action research in motion. New York, NY: Routledge.

Camargo-Borges, C. \& Rasera, E. F. (2013). Co-creation as resources of change. Social constructionism in the context of organization development: Dialogue, Imagination, and Co creation as Resources of Change. April-June 2013: 1-7. SAGE. DOI: 10.1177/2158244013487540

Ceglowski, D. (2000). Research as relationship. Qualitative Inquiry, 6 (1), 88 - 103. Doi/pdf/10.1177/107780040000600106"

Clausen, B. \& Sørensen, K. (Eds.) (2013). Inklusion så det batter - fællesskaber i vuggestue, børnehave og SFO. Frederikshavn: Dafolo Forlag.

Cooperrider, D. L. (1999). Positive image, positive action: The affirmative basis of organizing. In S., Srivasta \& D. L., Cooperrider. Appreciative management and leadership (pp. 401-442). San Fransisco, CA: Jossey Bass.

Cormack, D. F. S. (1996). The research process in nursing. Oxford, UK: Wiley.

Cronen, V. E., Pearce, W. G., \& Snavely, L. (1979). A theory of rules structure and episode types, and a study of perceived enmeshment in unwanted repetitive patterns. In D. Nimmo (Ed.). Communication Yearbook III (pp. 225-240). New Brunswick, NJ: Transaction.

D’Andrea, V. \& Gosling, D. (2005). Improving teaching and learning: A whole institution approach. Berkshire, UK: Open University Press.

Danmarks Lærerforening (2013). Lov 490 - udvalgte regler. Retrieved 07.01. 2016 from http://www.dlf.org/media/962619/dlf Lov409-pdf.pdf

Dannesboe, K.I., Kryger, N., Palludan, C. \& Ravn, B. (2012). Hvem sagde samarbejde? Et hverdagslivsstudie af skole-hjem-relationer. Århus, Denmark: Aarhus Universitetsforlag. 
Danske Kommuner (14 April, 2016). 12, s. 33. Børns rettigheder bliver krænket i alvorlige skolesager. Retrieved from 28.02.2017

http://www.danskekommuner.dk/Artikelarkiv/2016/Magasin-12/Borns-rettigheder-bliverkranket-i-alvorlige-skolesager-/

Davies, B. (2010). The implications for qualitative research methodology of the struggle between the individualised subject of phenomenology and the emergent multiplicities of the poststructuralist subject: The problem of agency. Reconceptualizing Education Research Methodology, 1 (1), 54-68.

Davies, B. (2014). Listening to children: Being and becoming. New York, NY: Routledge.

Davies, B. \& Harré, R. (1990): Positioning: The discursive production of selves. Journal for the Theory of Social Behaviour, 20 (1), 43-63. DOI: 10.1111/j.1468-5914.1990.tb00174.x.

Deleuze, G. (1999). Foucault: A critical introduction. London, UK: Continuum Press.

Deleuze, G. (1994). Difference and repetition (P. Patton Trans.). New York; NY: Colombia University Press.

Deleuze, G. \& Guattari, F. (1987). A Thousand plateaus: Capitalism and schizophrenia. (B. Massumi Trans.). Minneapolis, MN: University of Minnesota Press.

Denzin, N. K. \& Lincoln, Y. S. (2005). Handbook of qualitative research (3rd Edn.). Thousand Oaks, CA: Sage.

DESA (2009). Creating an inclusive society: Practical strategies to promote social integration.

Draft. Retrieved 06.05.2016 from

http://www.un.org/esa/socdev/egms/docs/2009/Ghana/inclusive-society.pdf

Dewey, J. (1938). Experience and education. Toronto, Canada: Collier-MacMillan.

Dewey, J. (1966). Democracy and education: An introduction to the philosophy of education. New York, NY: Free Press. 
Drewery, W. (2007). Restorative practice in schools - far-reaching implications. In G. M. Maxwell, \& J.H. Liu (Eds.) Restorative Justice and practices in New Zealand: Towards a Restorative Justice. Eugene, OR; Wipf \& Stock.

Drewery, W., Winslade, J. \& McMenamin, D.J. (2002). Restorative Practices for schools. Commissioned research reports for external body. New Zealand, University of Waikato.

Drewery, W. \& Kecskemeti, M. (2008). Restorative practices: Implications for teacher education. (Keynote address). Parent Document: Teacher Education Forum of Aotearoa New Zealand (TEFANZ) Biennial National Conference. New Zealand, University of Waikato.

Drewery, W., \& Winslade, J. (2005). Developing Restorative Practices in schools: Some reflections. New Zealand Journal of Counselling. 26(1), 16-32 Retrieved 28.02.2017 from https://researchcommons.waikato.ac.nz/bitstream/handle/10289/9571/Drewery\%20\%26\%20 Winslade\%20NZJC\%202005.pdf?sequence=2\&isAllowed $=y$

Drugli, M.B., Larsson, B., Clifford, G. \& Fossum, S. (2007). Pervasive and non-pervasive conduct problems in a clinic sample aged 4-8 years: Child, family and day-care/school factors. Scandinavian Journal of Educational Research, 51 (5). Retrieved 01.03.2017 from http://www.incredibleyears.com/wp-content/uploads/pervasive-non-pervasive-conductproblems 6-06.pdf

Drugli, M.B. \& Onøien, R. (2010). Vanskelige forældresamtaler-gode dialoger. Frederikshavn, Danmark: Dafolo.

DSS (Department of Social Security) (1999). Opportunity for All: Tackling poverty and social exclusion. London, UK: The Stationery Office. Retrieved 01.03.2017 from http://www.bristol.ac.uk/poverty/downloads/keyofficialdocuments/Opportunity\%20for\%20All \%201999\%20Full\%20Report.pdf

Duffy, K. (1995). Social exclusion and human dignity in Europe. Strasbourg, France: Council of 
Europe. Retrieved 01.03.2017 from https://www.amazon.co.uk/d/cka/Social-Exclusion-HumanDignity-Europe-Background-Initiative/B0018RBSO6.

Dyson, A. (1999). Inclusion and inclusions: Theories and discourses in inclusive education. In H., Daniels \& P., Garner (Eds.) Inclusive education - world yearbook of education. Kogan Page.

Dyssegaard, C.B., Larsen, M. S. \& Tiftikçi, N. (2013). Effekt og pædagogisk indsats ved inklusion af børn med særlige behov i grundskolen. Systematisk review. Dansk Clearinghouse for uddannelsesforskning. Aarhus, Denmark: Aarhus Universitet.

Dyssegaard, C. B. \& Larsen, M. S. (2013). Viden om inklusion. Dansk Clearinghouse for Uddannelsesforskning. Institut for Uddannelse og Pædagogik (DPU). Aarhus, Denmark: Aarhus Universitet.

Edwards, D., \& Potter, J. (1992). Discursive psychology. Journal of Community \& Applied Social Psychology, 5 (1) vii + 200. London, UK: Sage. DOI: 10.1002/casp.2450050106

Ejrnæs, M. (1999). Social Arv - et populært, men tvivlsomt begreb. Arbejdspapir 12 om social arv. København, Danmark: Socialforskningsinstituttet. Retrieved 01.03.2017 from http://www.sficampbell.dk/Files/Filer/SFI/Pdf/Arbejdspapirer/Arbejdspapirer/socialarv popular.pdf

Ejrnæs, M., Gabrielsen, G. \& Nørrung, P. (2004). Social arv, social opdrift. København, Danmark: Akademisk Forlag.

Ejrnæs, M. (2011). Social Arv. In I. H., Møller \& J. E., Larsen (Eds.) Socialpolitik (pp. 189 - 209). København, Danmark; Hans Reitzels Forlag,

Elsborg, S,. Hansen, T. J. \& Hansen, V. R. (1999). Den sociale arv set ud fra det salutogene perspektiv. København, Danmark: Socialforskningsinstituttet.

Ellington, L. L. \& Ellis, C. (2008). Autoethnography as constructionist project. In J. A. Holstein \& J. F. Gubrium (Eds.) Handbook of constructionist research. (pp. 445- 467) New York, NY \& London, UK: The Guilford Press. 
Ellis, C., \& Bochner, A. P. (Eds.) (1996). Composing ethnography: Alternative forms of qualitative writing. Walnut Creek, CA: AltaMira Press.

Farrell, P. (2004). School psychologists: Making inclusion a reality for all. School Psychology International 25 (5), 5-19. DOI: 10.1177/0143034304041500

Esmark, K. (2006). Bourdieus uddannelsessociologi. In J. A. Prieur, \& C. Sestoft, (Eds.) Pierre Bourdieu - en introduktion. København, Danmark: Hans Reitzels Forlag.

Estivill, J. (2003). Concepts and strategies for combating social exclusion. Geneva, Switzerland: International Labour Office.

Epstein, J. (2001). School, family, and community partnerships: Preparing educators and improving schools. Colorado, US: Westview.

EVA (2010). Forstudie til evaluering af AKT-indsatsen i folkeskolen, 2010. København, Danmark: Evalueringsinstitut på: www.eva.dk

Fine, M. (1989). Silencing and nurturing voice in an improbable context: Urban adolescents in public school. In H. Giroux \& P. McLaren (Eds.), Critical pedagogy, the state and cultural struggle. (pp. 152-173). Albany, NY: State University of New York Press.

Fine, M: (1990). Making controversy: Who's at risk? Journal of Urban and Cultural Studies, I (I), $55-68$

Fine, M. (1991). Framing drop-outs: Notes on the politics of urban high school. Albany, NY: State University of New York Press.

Fine, M. (1994). Working the hyphens: Reinventing self and other in qualitative research. In N. Denzin \& Y. Lincoln (Eds.), Handbook of Qualitative Research (pp. 70-82). London, UK: Sage.

Fine, M. \& Cammarota, J. (Ed.) (2008). Revolutionizing education. Youth Participatory Action Research in Motion. New York, NY \& London, UK: Routledge, Taylor \& Francis Group, Fisker, T. B. (2013). Udvikling i antal børn i eller med vanskeligheder. I: Pædagogisk 
Psykologisk Tidsskrift, 50 (6), 17-29.

Fisker, T. B. \& Szulevicz, T. (2015). Inklusion og folkeskolereformen. In J., Rasmussen, C. Holm \& A., Rasch-Christensen (Eds.). Foleskolen efter reformen. Riga, Letland,: Hans Reitzels Forlag.

Foster, E. \& Bochner, A.P. (2008). Social constructionist perspectives in communication research. In J. A. Holstein, \& J.F. Gubrium, (Eds.) (2008). Handbook of constructionist research. New York, NY \& London, UK: Guilford Press.

Foucault, M. (1980). Two lectures, power/knowledge: Selected interviews and other writings 1972 - 1977. New York, NY: Pantheon.

Foucault, M (1988). Technologies of the self. Amherst, MA: The University of Massachusetts Press.

Foucault, M. (2000). The subject and power. In J. D., Faubion (Ed), Power - The essential works 3. London, UK: The New Press

Foucault, M. (2002). Overvågning og straf. Frederiksberg, Danmark: Det lille forlag.

Freeland, J. (1991). Dislocated transitions: Access and participation for disadvantaged young people. In B. Finn (Ed.). Young people's participation in post-compulsory education and training (Vol. 3) (pp. 161-22). Canberra, Australia: Australian Government Printing Service.

Freeman, M. (2010). Knowledge is acting: 'Working-class parents' intentional acts of positioning within the discursive practice of involvement. International Journal of Qualitative Studies in Education, 23 (2) 181-198. http://dx.doi.org/10.1080/09518390903081629

Freire, P. (1970). Pedagogy of the oppressed (M. Ramos, Trans.). New York, NY: Seabury.

Fullan, M. (2003). The moral imperative of school leadership. Thousand Oaks, CA, Corwin Press.

Fullan, M. (2010). All Systems Go: The change imperative for whole system reform. Thousand Oaks, CA; Corwin Press.

Fullan, M. (2006). Change theory - A force for school improvement. Centre for Strategic Education. 
Seminar Series Paper No. 157. Retrieved May 2015 from http://michaelfullan.ca/wpcontent/uploads/2016/06/13396072630.pdf

Fullan, M. \& Hargreaves, A. (2012). Professional capital: Transforming teaching in every school. New York, NY: Teachers College Press.

Galvan, J. (2005). Writing a literature review (3rd Edn.). Los Angeles, CA: Pyrczak.

Garrigle, M.M. (2015). Interim evaluation report on the use and impact of Restorative Practices in Letterkenny vocational school during the school year. Sept 2004 - June 2005. Retrieved 01.03.2017 from www.transformingconflict.org

Gehart, D., Tarragona, M., \& Bava, S. (2007). A collaborative approach to research and inquiry. In H. Anderson \& D. R. Gehart, (Eds.). Collaborative therapy: Relationships and conversations that make a difference (pp. 367-387). New York, NY: Brunner-Routledge.

Gergen, K. J. (1994). Realities and relationships: Soundings in social construction. Cambridge, MA: Harvard University Press.

Gergen, K. (1999b). Agency. Social construction and relational action. Theory and Psychology, 9, (1), 113-115. DOI: org/10.1177/0959354399091007.

Gergen, K. (1999a). An invitation to social construction. London, UK: Sage.

Gergen, K. J. \& McNamee, S. (2000). From disordering discourse to transformative dialogue. In R. Neimeyer \& J. D. Raskin (Eds.). Constructions of disorder: Meaning-making frameworks for psychotherapy (pp. 333-349). Washington, DC: American Psychological Association.

Gergen, M. \& Gergen, K. (2000). Qualitative inquiry: Tensions and transformations. In N. K. Denzin \& Y. S. Lincoln (Eds.). Handbook of qualitative research (2nd Edn.) (pp. 1025-1046). Thousand Oaks, CA: Sage.

Gergen, K. (2001). Social construction and pedagogical practice. In S. Wortham, Social Construction in context. Thousand Oaks, CA: Sage. DOI: 
$. \operatorname{org} / 10.4135 / 9781446219645 . n 8$

Gergen, K. J. \& Gergen, M. M. (2006a). Narratives in action. Narrative inquiry, 16, 119-128. DOI: 10.1075/ni.16.1.15ger.

Gergen, K. J. (2006b). Therapeutic realities: Collaboration, oppression and relational flow. Chagrin Falls, $\mathrm{OH}:$ Taos Institute.

Gergen, K. J. \& Gergen, M. (2008). Social construction: Entering the dialogue. Chagrin Falls, OH: Taos Institute.

Gergen, K. J. (2009a). Relational being: Beyond self and community. New York, NY: Oxford University Press.

Gergen, K. J. (2009b). An invitation to social construction (2nd Edn.). Thousand Oaks, CA: Sage.

Gergen, K. (2015). From mirroring to world-making: Research as future forming. Journal for the Theory of Social Behaviour, 45, (3), 287-310. DOI: 10.1111/jtsb.12075.

Gergen, K. (2017). Social Construction: Orienting principles: Thoughts from Kenneth J. Gergen. Retrieved 16.02.2017 from http://www.taosinstitute.net/theoretical-background.

Gibbs (2010). Using assessment to support student learning at UEA. Norwich, UK: The University of East Anglia.

Gilliam, L. (2012). Den umulige klasse. Skolens identitetslektioner for ressourcesvage børn. In L. Gilliam \& E. Gulløv: Civiliserende institutioner. Om idealer og distinktioner i opdragelse. Aarhus, Denmark: Aarhus Universitetsforlag.

Giroux, H. \& McLaren, P. (1992). Writing from the margins: Geographies of identity, pedagogy, and power. Journal of Education. 174 (1), 7-30. DOI

Giroux, H. (2006). The Giroux reader. London, UK: Boulder Paradigm Publishers.

Goodenow,C. (1993a). Thepsychological sense of schoolmembership among adolescents: Scale development and educational correlates. Psychologyin the Schools. 30(1), 70-90. 
DOI: 10.1002/1520-6807(199301)30:1<79::AID-PITS2310300113>3.0.CO;2-X.

Goodenow, C. (1993b). Classroom belonging among early adolescent students: Relationships to motivation and achievement. Journal of Early Adolescence. 13 (1), 21-43. DOI: 10.1177/0272431693013001002.

Gordon, D., Adelman, L., Ashworth, K., Bradshaw, J., Levitas, R., Middleton, S., Pantazis, C., Patsios, D., Payne, S., Townsend, P. \& Williams, J. (2000). Poverty and social exclusion in Britain. York, UK: Joseph Rowntree Foundation. Retrieved from 01.03.2017

http://www.bris.ac.uk/poverty/pse/Poverty\%20and\%20Social\%20Exclusion\%20in\%20Britain\%2 OJRF\%20Report.pdf

Graham, L. J. (2008). From ABCs to ADHD: The role of schooling in the construction of behaviour disorder and production of disorderly objects. International Journal of Inclusive Education. 12 (1), 7-33. Doi.org/10.1080/13603110701683311

Graham, L. J. \& Slee, R. (2006). Inclusion? Paper presented at the American Educational Research Association (AERA) 2006 Annual Conference, April 6-11, San Francisco. Retrieved from 01.03.2017 https://core.ac.uk/download/pdf/10875327.pdf

Graham, L. J. \& Slee, R. (2007). An Illusory Interiority: Interrogating the discourse/s of inclusion. Educational Philosophy and Theory, 40 (2), 277-293. DOI: 10.1111/j.1469-5812.2007.00331.x

Grant, B. (1997). Disciplining students: The construction of student subjectivities. British Journal of Sociology of Education, 18 (I), 101-114. DOI: 10.1080/0142569970180106.

Gubrium, J. \& Holstein, J. (1998). Narrative practices and the coherence of personal stories. Sociology Quarterly, 39 (1), 163-187.

Gutman, L. M. \& Vorhaus, J. (2012). The Impact of pupil behaviour and wellbeing on educational outcomes. Institute of Education, University of London. Research Report DFE-RR253. Retrieved from 01.03.2017 
https://www.gov.uk/government/uploads/system/uploads/attachment data/file/219638/DFERR253.pdf

Hacking, I. (2000). The social construction of what? Cambridge, MA: Harvard University Press.

Hall, S. (1988). The toad in the garden: Thatcherism among the theorists. In L. Grossberg \& C. Nelson

(Eds.). Marxism and the interpretation of culture (pp. 35-73). Urbana, IL \& Chicago, IL:

University of Illinois Press.

Hall, S. (1990). Cultural identity and diaspora. In J. Rutherford (Ed.). Identity: Community, culture and difference (pp. 222-237). London, UK: Lawrence \& Wishart.

Hansen, H. R. (2005). Grundbog mod mobning. København, Danmark, Gyldendal.

Hansen, H. R. (2009). Straf mod mobning og skoleuro. In Kofoed, J. \& Søndergaard, D.M. Mobning. Sociale processer på afveje (pp. 133-165). København, Danmark: Hans Reitzels Forlag.

Hansen, H. R. (2016). Parentesmetoden. Tænkestrategier mod mobning. Frederikshavn, Danmark: Dafolo Forlag.

Hansen, A. T., Friis-Hansen, M. \& Jensen, V. M. (2015). SFI notat. Folkeskolereformen. Beskrivelse af 1. dataindsamling. København, Danmark: Det Nationale Forskningscenter for Velfærd. Retrieved 14.05.2016 from

https://pure.sfi.dk/ws/files/384994/Notat Folkeskolereformen Dokumentation af dataindsamling.pdf

Hargreaves, A. \& Fullan, M. (2012). Professional capital - transforming teaching in every school. New York, NY: Teachers College Press.

Harré, R. (2012). Positioning theory: Moral dimensions of social-cultural psychology. In J. Valsiner (Ed.). The Oxford Handbook of Culture and Psychology (pp. 191-206). New York, NY: Oxford University Press.

Harré, R. \& Moghaddam, F. (Eds). (2003). The Self and others. Positioning individuals and groups in personal, political and cultural contexts. Westport, CT; Greenwood Publishing. 
Harré, R. \& Van Langenhove, L. (1999). Positioning theory: Moral contexts of intentional action. Malden, MA; Blackwell.

Haslebo, G. \& Lund, G. E. (2014). Relationsudvikling i Skolen. Viborg, Danmark: Dansk Psykologisk Forlag.

Haslebo G. \& Haslebo, M. L. (2012). Practicing relational ethics in organizations. Chagrin Falls, Ohio: Taos.

Hattie, J. A. C. (2009). Visible learning. A synthesis of over 800 meta-analyses relating to achievement. London, UK \& New York, NY: Routledge Taylor \& Francis Group.

Hattam, R. \& Smyth, J. (2014). Thinking past educational disadvantage, and theories of reproduction. Sociology, 2015, 49 (2), 270-286. DOI: https://doi.org/10.1177/0038038514540578

Hauger, B. (2015). Anerkendende processer som drivkraft for kulturudvikling i større systemer. S.

I. G. E. Lund \& G. Haslebo (Eds.), (2015). Kulturudvikling i skolen - hvordan? (pp. 185 - 212). Viborg, Danmark: Dansk Psykologisk Forlag.

Haavimb, M. E. (2015). CosmoKidz - børns læring som drivkraft for skoleudvikling. S. 47 - 76. In G., E., Lund \& G., Haslebo (Eds.), (2015). Kulturudvikling i skolen - hvordan? Viborg, Danmark: Dansk Psykologisk Forlag.

Hedegaard Hansen, J. (2011). Barrierer for inklusion i den pædagogiske praksis. Pædagogisk Psykologisk Tidsskrift. 48. årgang, Vol. 3. Temanummer: Inklusions- og eksklusionsprocesser i sociale sammenhænge. Virum, Danmark. Dansk Psykologisk Tidsskrift.

Henriksen, K. (2008). Hver anden handleplan mod mobning er en ommer. Dansk Center for undervisningsmidler. Retrieved 01.03.2017 from http://dcum.dk/sammen-modmobning/hveranden-handleplan-mod-mobning-er-en-ommer

Hertz, S. (2010). There is a crack in everything - that's how the light gets in. In S. Brinkmann 
(Ed.), Det diagnosticerede liv-sygdom uden grænse. Århus, Danmark: Forlaget Klim.

Hine, J. \& Mitchell, F. (2001). Scottish Executive. The role of transport in social exclusion in urban Scotland: Edinburgh, UK: Central Research Unit, Saughton House. Retrieved 01.03.2017 from https://trid.trb.org/view.aspx?id=693698

Holst, J. (2007). Det normale og det afvigende. In P. Ø. Andersen, P. Ellegaard og L. J. Muschinsky (Eds.). Klassisk og Moderne pædagogisk teori. (pp. 301-324). København, Danmark: Hans Reitzel.

Holst, L. \& Madsen, K. H. (2009). Den inkluderende skole anno 2009. Et spørgsmål om ro og orden? Danmarks pædagogiske Universitet, DPU. Pædagogisk Sociologi. (kandidatspeciale) Holstein, B., Mehlbye, J. Knoop, H. H. \& Hansen, H. R. (2014). Endelige anbefalinger fra ekspertgruppen om elevers trivsel i folkeskolen i relation til nationale trivselsmålinger. Rapport udarbejdet af ekspertgruppen for Undervisningsministeriet. www.uvm.dk/140520. Holstein, J. A. \& Gubrium, J. F. (Eds.). (2008). Handbook of constructionist research. New York, NY \& London, UK: Guilford Press.

Holstein, J. A., \& Gubrium, J. F. (2000). The self we live by: Narrative identity in a postmodern world. New York, NY: Oxford University Press.

Hosking, D. M., Dachler, P. D., \& Gergen, K. J. (Eds.) (2013). Management and organization: Relational alternatives to individualism. Avebury: A Taos Institute Publication.. Howarth, C., Kenway, P., Palmer, G., \& Street, C. (1998). Monitoring poverty and social exclusion: Labour's inheritance. York, UK: NPI/Joseph Rowntree Foundation.

Højholt, C. (2005). Forældresamarbejde. Forskning i fællesskab. Virum, Danmark: Dansk psykologisk Forlag.

Jensen, B. (2015). Social arv, ulighed og dagtilbuds betydning mhp mønsterbrydning. Analyse 
baseret på teoretiske begreber, empiriske undersøgelser og eksempler på social innovation i dagtilbud. Pædagogisk Psykologisk Tidsskrift. Den Blå Serie, nr. 52.

Jespersen, J. \& Hansen, T. B. (2013). Pejlemærker for kompetenceudviklingen i folkeskolen.

Udgivet af Undervisningsministeriet.

Jordan, B. \& Henderson, A. (1994). Interaction analysis: Foundations and practice. IRL Report No.

IRL 94-0027, July, 1994. Retrieved 08.02.16 from

http://www.lifescapes.org/Papers/94\%20IA\%20IRL.pdf

Juelskjær, M. (2009). En ny start: bevægelser i/gennem tid, rum, krop og sociale kategorier via begivenheden skoleskift. Ph.d.-afhandling. København, Danmark: Danmarks Pædagogiske Universitets Forlag.

Jæger, M. M. (2003). Mønsterbrydere og social arv i Danmark. Perspektiver fra Socialforskningsinstituttets ungdomsforløbsundersøgelse. København. Arbejdspapir 7. Vidensopsamling om Social Arv 07: 2003. Socialforskningsinstituttet. Retrieved 02.03.2017 from http://www.sfi.dk/publikationer/moensterbrydere-og-social-arv-i-danmark-10753/ Jørgensen (2016). Etnicitet som en del af en social ulighedsproblematik i Danmark. Pædagogisk Psykologisk Tidsskrift, Rød serie, projekt-nr. 40. København, Danmark: Dansk Psykologisk Forlag. Jørgensen, A. S. W., Blankenberg, M., Skall, U., \& Schjerbeck, R. H. (Eds.), Afrapportering af inklusionseftersynet. Den samlede afrapportering. Udgivet af Ministeriet for Børn, Undervisning og Ligestilling, maj 2016.

Kecskemeti, M. (2004, December). Restorative Conversations - Is changing ways of speaking enough to change relationships, discipline systems and school cultures? Paper presented at "New Frontiers in Restorative Justice: Advancing Theory and Practice" conference, Centre for Justice and Peace Development, Massey University at Albany, New Zealand, 2-5 December. Retrieved from http://restorativejustice.org/rj-library/restorative-conversations---is-changing-ways-of- 
speaking-enough-to-change-relationships-discipline-systems-and-schoolcultures/5649/\#sthash.w6rffW8n.dpbs

Kecskemeti, M. (2011). A discursive approach to relationship practices in classrooms: An exploratory study. Unpublished doctoral thesis. Hamilton, NZ: University of Waikato.

Kecskemeti, M. \& Winslade, J. (2016). Better classroom relationships. Wellington, New Zealand: NZCER. Kenway, J., Willia, S., Blackmore, J. \& Rennie, L. (1994). Making 'hope' practical rather than 'despair' convincing: Feminist post-structuralism, gender reform and educational change. British Journal of Sociology of Education, 15 (2), 187-210. http://dx.doi.org/10.1080/0142569940150203

Kirkegaard, J. (2014, Marts 11). Selviske forældre ødelægger inklusion i skolen. Politiken. Retrieved 11.03.2014 from http://politiken.dk/debat/kroniken/art5507781/Selviske-for\%C3\%A6ldre\%C3\%B8del\%C3\%A6gger-inklusion-i-skolen.

KL (2013). Aftale mellem regeringen (Socialdemokraterne, Radikale Venstre og Socialistisk Folkeparti), Venstre og Dansk Folkeparti om et fagligt løft af folkeskolen. D. 7. Retrieved 15.06.2015 from

http://www.kl.dk/ImageVault/Images/id62271/scope0/ImageVaultHandler.aspx

Klasen, S. (2001). Social exclusion, children, and education: Conceptual and Measurement issues.

Department of Economics University of Munich. Retrieved 01.03.2017 from www.oecd.org/education/school/1855901.pdf

Kloppenborg, H.S. \& Wittrup, J. (2015). Sårbare børn-hvem er de, hvor bor de, og hvordan klarer de sig i skolen? Socialstyrelsen. Det Nationale Institut for Kommuners og Regioners Analyse og Forskning.

Klinge, L (2016). Lærernes relationskompetence. Ph.d.-afhandling. København, Danmark: Metropol og Københavns Universitet.

Knudsen, H. (2008a). Forældreledelse: Let's be careful out there! In C. Sløk \& K. Villadsen 
Velfærdsledelse. Ledelse og styring I den selvstyrende velfærdsstat. København, Danmark: Hans Reitzels Forlag, s. 69-97.

Knudsen, H. (2008b). Har vi en aftale? (U)mulighedsbetingelser for mødet mellem folkeskole og families. Ph.d.-afhandling. København, Danmark: Danmarks Pædagogiske Universitetsskole, Århus Universitet.

Knudsen, H. (2010). Har vi en aftale? - magt og ansvar i mødet mellem folkeskole og familie. Frederiksberg, Danmark: Nyt fra samfundsvidenskaberne.

Kofoed, J., Henningsen, I. \& Hansen, H. R. (2013). Når klassekultur tipper over i mobning. In J., Kofoed \& D., M., Søndergaard (Eds.). Mobning gentænkt (pp. 21-55). København, Danmark: Hans Reitzels Forlag.

Koro-Ljungberg (2008). A social constructionist framing of the research interview. In J. A. Holstein \& J. F. Gubrium (Eds.), Handbook of Constructionist Research, (pp. 429 - 444.) New York, NY. The Guilford Press

Krogh, Z. \& Smidt, S.L. (2015). Forældresamarbejde, der virker. Viborg, Danmark: Dansk Psykologisk Forlag.

Kryger, N. \& Ravn, B. (2007). Skole-hjem-samarbejde: for barnets bedste? In L., Moos (Ed.). Nye sociale teknologier i folkeskolen: Kampen om dannelse (pp. 91-103). Frederikshavn, Danmark: Dafolo,.

Kutchins, H., \& Kirk, S.A. (1997). Making us crazy: DSM The psychiatric bible and the creation of mental disorders. New York, NY: The Free Press.

Lather, P. (1986). Research as praxis. Harvard Educational Review, 56 (3), 257-277.

Lather, P. (1991). Getting smart. Feminist research and pedagogy with/in the postmodern. New York, NY: Routledge.

Larsen, M.R., Akselvoll, M. Ø., Jartoft, V. Knudsen, H., Kousholt, D. \& Raith, J. K. (2014). 
Forældresamarbejde og inklusion. Afdækning af et vidensfelt i bevægelse. København, Danmark: DPU. Danmarks institut for Pædagogik og Uddannelse. Retrieved 03.11.2015 from http://www.emu.dk/sites/default/files/140815\%20Rapport\%20om\%20foraeldresamarbejde\%2 0og\%20inklusion\%20med\%20bilag.pdf

Larsen, J. E., \& Mortensen, N. (2009a). Udenfor eller indenfor. Sociale marginaliseringsprocessers mangfoldighed. København, Danmark: Hans Reitzels Forlag.

Larsen, J. E. (2009b). Lige muligheder og socialt udsatte. In N., Holtug\& K. Lippert-Rasmussen (Eds.): Lige muligheder for alle. Social arv, kultur og retfærdighed. Frederiksberg, Danmark: Nyt fra samfundsvidenskaberne.

Larsen, J. E. (2009c). Forståelser af begrebet social udsathed. In P., Brandt, B. L., Henriksen, K., B., Jensen \& N. C., Rasmussen (Eds.) Udsat for forståelse - en antologi om socialt udsatte. S. 17 42. Silkeborg. Rådet for socialt udsatte.

Lauritzen, L. (2016). "Social arv" - kategoriseringseffekter og styrende forventninger. Social Ulighed. Pædagogisk Psykologisk Tidsskrift, Rød serie, projektnr. 40, Virum, DK: Dansk Psykologisk Forlag.

Levin, B. (2012). How to change 5000 schools. A practical and positive approach for leading change at every level. Cambridge, MA; Harvard Education Press.

Levitas, R., Pantazis, C., Fahmy, E., Gordon, D., Lloyd, E., \& Patsios, D. (2007). The Multi-dimensional Analysis of Social Exclusion. Bristol, UK: University of Bristol. Retrieved 01.03.2017 from http://dera.ioe.ac.uk/6853/1/multidimensional.pdf

Lock, A. \& Strong, T. (2010). Social constructionism: Sources and stirrings in theory and practice. Cambridge, UK: Cambridge University Press.

Lund, G. E. \& Haslebo, G. (2015). Kulturudvikling i skolen - hvordan? Viborg, Danmark. Dansk Psykologisk Forlag. 
Lund, G. E. (2015). Socialkonstruktionisme i organisationer - Kort fortalt. Viborg, Denmark: Dansk Psykologisk Forlag.

Luttrell, W. (1996). Becoming somebody in and against school: Towards a psycho-cultural theory of gender and self-making. In B. Levinson, D. Foley \& D. Holland (Eds.). The cultural production of the educated person: Critical ethnographies of schooling and local practice (pp. 93-117). Albany, NY: State University of New York Press.

Madsen, B. (2005). Socialpædagogik - Integration og inklusion i det moderne samfund. København, DK: Hans Reitzels Forlag, 1. udgave, 8. oplag

Madsen, A. (2008). Forældreinklusion - at gøre tynde historier tykkere. In R., Alenkær (Ed.) Den inkluderende skole. En grundbog. pp. 313- 339. Frederiksberg; Danmark: Frydenlund.

Malone, K. \& Hasluck, L. (1998). Geographies of exclusion: young people's perceptions and use of public space. Family Matters, 49, 20-26.

Margonis, F. (1992). The co-operation of 'at-risk': Paradoxes of policy criticism. Teachers College Record, $94(2), 343-364$.

Marinosson, G. Ohna, S. E., \& Tetler, S. (2007). Delagtighedens pædagogik. Temanummer: Inkluderende Pædagogik i Norden. Pædagogisk Psykologisk Tidsskrift. August 2007, Årgang 44. nr. 3. Virum, Danmark: Dansk Psykologisk Forlag.

Mark Jensen, T. \& Ravn Olesen, B. (2011). Samarbejde mellem skole og hjem. København, Danmark: Dansk Psykologisk Forlag.

McAdams, D. (2006). The role of narrative in personality psychology today. John Benjamins Publishing Company. Narrative Inquiry, 16 (1), 11-18. Retrieved 01.03.2017 from https://www.sesp.northwestern.edu/docs/publications/1049432884490a09930cdc3.pdf

McAdam, E. \& Lang, P. (2010). Anerkendende arbejde i skoler. At skabe fælles trivsel. København, Danmark: Forlaget Mindspace. 
McGarrigle, M. (2005). Interim evaluation report on the use and impact of Restorative Practices in Letterkenny Vocational School during the school year 2004-2005. Feidmeannacht na Seirbhise Slainte. Health Service Executive.

McGrath, M. J. (2006). School bullying: Tools for avoiding harm and liability. Thousand Oaks, CA: Corwin Press.

McNamee, S. (2002). The social construction of disorders: From pathology to potential. In J. D. Raskin \& S.K. Bridges (Eds.). Studies in meaning: Exploring constructivist psychology. New York, NY: Pace University Press.

McNamee, S., \& Gergen, K. J. (1998). Relational responsibility: Resources for sustainable dialogue. Thousand Oaks, CA: Sage.

McNamee, S. (2007). Relational practices in education: Teaching as conversation. In H. Anderson \& D. Gehart (Eds.). Collaborative therapy: Relationships and conversations that make a difference (pp. 313-335). New York, NY: Brunner-Routledge.

McNamee, S. (2010). Research as Social Construction: Transformative Inquiry. Saúde \& Transformação Social. Health \& Social Change. Sau. \& Transf. Soc., Florianópolis, 1 (1), 9-19. McNamee, S. \& Hosking, D.M. (2012). Research and social change: A relational constructionist approach. New York, NY: Routledge.

McNamee, S. (2014). Constructing knowledge/constructing inquiry: Coordinating research worlds. In G. Simon \& A. Chard (Eds.), Systemic Inquiry Innovations in reflexive practice research. London, UK: Everything is Connected Press.

Maclntyre, A. (1981). After virtue: A study in moral theory. Notre Dame, IN: University of Notre Dame Press.

McLaren, P. (1989). Life in schools: An introduction to critical pedagogy in the foundations of education. New York, NY:Longman. 
MacPherson, P. \& Fine, M., (1995). Hungry for us: Adolescent girls and adult women negotiating territories of race, gender, class and difference. Feminism and Psychology, 5 (2), 181-200.

Meadmore, D. (1999). Mapping the landscape. In D. Meadmore, B. Burnett \& P. O'Brien (Eds.) Understanding education: Contexts and agendas for the next millennium (pp. 1-10). Sydney, NSW: Prentice Hall.

Metzler, C.W., Biglan, A., Rusby, J.C., \& Sprague, J.R. (2001). Evaluation of a comprehensive behavior management program to improve school-wide positive behavior support. Education and Treatment of Children, 24 (4), 448-79.

Ministry of Education, New Zealand (2012). Restorative Practices in NZ: The Evidence Base. Te Táhuhu I te Mátauranga. Positive Behavior for Learning.

Mirsky, L. \& Korr, S. (2014). Restoring Community and Trust. Principal Leadership, 32. Fly Fernandez/Corbis.

Moghaddam, F. \& Harré, R. (eds.) (2010). Words of conflict, words of war: How the language we use in political processes sparks fighting. Santa Barbara, CA: Praeger.

Molbæk, M. (2015). Klasseledelse med fokus på inklusion. In O., LøW, (Ed.). Klasseledelse: Praktikbog 2 til læreruddannelsen. København; Danmark; Akademisk Forlag. Monk, G. \& Winslade, J. (2008). Practicing Narrative Mediation - Loosening the grip of conflict. San Francisco, CA: Jossey-Bass.

Monk, G. \& Winslade, J. (2013). When stories clash: Addressing conflict with narrative mediation. Chagrin Falls, $\mathrm{OH}$; Taos Institute.

Moos, L. (2009). Inklusion og ledelse. Skolen i Morgen. Tidsskrift for skoleledere. Nr. 1. 13.årgang. Morgan, D. L. (2008). Snowball sampling. In L. M., Given (Ed). The Sage Encyclopedia of Qualitative Research Methods (pp. 816-817). Thousand Oaks, CA. Sage. Morrison, G.M. \& D'Incau, B. (2000). Developmental and service trajectories of students with 
disabilities recommended for expulsion from school. Exceptional Children, 66, 257-272.

Muschinsky L. J. (Ed.) (2016). Klassisk og moderne pædagogisk yeori. København, Danmark; Hans Reitzels Forlag.

Mæland, I. \& Hauger, B. (2011). Anerkendende elevsamtaler. Elevinddragelse fremtidsplanlægning og forebyggelse af frafald i uddannelse. København, Danmark: Forlaget Mindspace.

Nielsen, L. T. (2012). Teamsamarbejdets dynamiske stabilitet - en kulturhistorisk analyse af læreres læring i team. Ph.d.-afhandling. Aarhus; Danmark: Aarhus Universitet og UUC Nielsen, H. W. (2003). Den pædagogisk-psykologiske undersøgelse og vurdering. In Psykologisk Pædagogisk Rådgivning, 40 (6). Virum, DK: Dansk Psykologisk Forlag.

Nordahl, T. (2008). Hjem og skole. Hvordan skaber man et bedre samarbejde? København, Danmark: Hans Reitzels Forlag.

Nordenbo, S.E., Larsen, M. S., Tiftikci, N. Wendt, R. E., \& Østergaard, S. (2008). Lærerkompetencer og elevers læring i førskole og skole. Dansk Clearinghouse for uddannelsesforskning. København, Danmark; Danmarks Pædagogiske Universitetsforlag.

Nordentoft, H.M., Thomsen, R. \& Wichmann-Hansen, G. (2012). Collective academic supervision: A model for participation and learning in higher education. DOI 10.1007/s10734-0129564-x.

Nørgaård, H. (2006). Handikapperspektiver og social integration. Specialpædagogik 2. Retrieved from http://docplayer.dk/25827036-Handicapperspektiver-og-social-integration.html Oliver, M. (1992). Intellectual masturbation: A rejoinder to Söder and Booth. European Journal of Special Needs Education, 7 (1), 20-28.

Ottosen, M. H. \& Andersen, D., Nielsen, L. P., Lausten, M. \& Stage, S. M. H. (2010). Børn og unge i 
Danmark - Velfærd og trivsel 2010. København; Danmark: SFI - Det Nationale Forskningscenter for Velfærd. Retrieved 01.03.2017 from http://www.sfi.dk/publikationer/boern-og-unge-idanmark-velfaerd-og-trivsel-2010-4636/

Ottosen, M. H., Andersen, D., Dahl, K. M., Hansen, A. T., Lausten, M. \& Østergaard, S. V. (2014). Børn og Unge i Danmark. Velfærd og trivsel 2014. København; Danmark: SFI - Det Nationale Forskningscenter for Velfærd. Retrieved 01.03.2017 from http://www.bedrepsykiatri.dk/media/30583/1430-boern-og-unge.pdf

Overland, T. (2009). Skolen og de udfordrende elever. Om forebyggelse og reduktion af problemadfærd. Frederikshavn, Danmark: Dafolo.

Paré, D. (2011). Reflective learning through collaborative practice groups. International Journal of Collaborative Practices 2 (1), 24-35.

Parker, I. (1992). Discourse dynamics: Critical analysis for social and individual psychology. London, UK: Routledge.

Pearce, K. (2014). Kim Pearce-CMM Original story (video). Tucson, AZ: The CMM Institute. Retrieved 01.03.2017 from http://www.cmminstitute.net/content/kim-pearce-cmm-originalstory

Pearce, W. B., \& Littlejohn, S. (1997). Moral conflict: When social worlds collide. Thousand Oaks, CA: Sage.

Pearce, W. B. (2006). Doing research from the perspective of the coordinated management of meaning (CMM). Santa Barbara, CA: Fielding Graduate University. Retrieved 01.03.2017 from https://www.taosinstitute.net/Websites/taos/files/Content/5692988/Overview of CMM in R esearch version 2.0.pdf

Pearce, B. (2007). Making social worlds: A communication perspective. Malden, MA: Blackwell. Pearce, B. (2008). Making social worlds. New York, NY: Wiley. 
Pearce, K. (2014): Reflections of CosmoKidz in kindergarten through second grade classes at Mountain Vista School in Oracle, Arizona. Retrieved 16. 11. 2016 from http://cmminstitute.net/sites/default/files/documents/Research\%20on\%20the\%20effectivene ss\%20of\%20CosmoKidz.pdf

Petersen, M. H. (2013). Når krav om inklusion af elever betyder kollaps af mening for lærere. Kognition og Pædagogik. Tidsskrift om gode læringsmiljøer, 87 (23), 64-73.

Phil, M. D. (2014). Negativ social arv. Folkeskolen skaber mønsterbrydere. København. Arbejderbevægelsens erhvervsråd. Retrieved 18.11.2016 from https://www.ae.dk/analyser/folkeskolen-skaber-moensterbrydere Plauborg, H. (2011). Klasseledelse og fællesskabende didaktikker: Om meningsfulde læringsmuligheder og værdig deltagelse i undervisningen.Kvan, 31 (90), pp. 67-78.

Ploug, N. (Ed.) (2008). Social arv og social ulighed. København, Danmark: Hans Reitzels Forlag. Rambøll (2011). Evaluering af mere frit skolevalg (2.0). Rapport, november 2011 til Ministeriet for Børn og Undervisning.

Rasmussen, J. (2015). Folkeskolereform 2014. In: J. Rasmussen, C. Holm \& A. Rasch-Christiensen (red.). Folkeskolen efter reformen (pp. 9-44.) Letland: Hans Reitzels Forlag.

Rasmussen, J., Holm, C, \& Rasch-Christensen, A. (Eds.), (2015). Folkeskolen - efter reformen. Riga, Letland: Hans Reitzels Forlag.

Rasmussen, M., Pedersen, T. P., \& Due, P. (Eds) (2015). Skolebørnsundersøgelsen 2014. København: Statens Institut for Folkesundhed 2015. Første www.si-folkesundhed.dk og www.hbsc.dk Ratner, H. (2013). Inklusion: dilemmaer i organisation, profession og praksis. København, Danmark: Akademisk Forlag.

Ravn, B. (2004). Forholdet mellem skole og hjem. I: L., Barner-Rasmussen \& M., Hermansen. 
Skole og hjem-samarbejdet - en håndsrækning til læreruddannelsen. København, Danmark; Unge Pædagoger.

Ravn, B. (2011). Skole-hjemsamarbejdets historie. Dansk Pædagogisk Tidsskrift, 2011 (1),

27-35.

Reason, P. \& Bradbury, H. (2008). Handbook of action research (2nd Edn.). London, UK: Sage.

Reason, P. \& Bradbury, H. (Eds.). (2007). Handbook of action research: Participative inquiry and practice (2nd ed.). London, UK: Sage.

Reay, D., David, M., \& Ball, S. (2001) Making a difference? Institutional habitus and higher education choice. Sociological Research Online, 5 (4). Available from: http://www.socresonline.org.uk/5/4/reay.html

Reed, J. (2007). Appreciative inquiry: Research for change. London, UK: Sage.

Reed, S. \& Procter, J. (1995). Practitioner research in health care: The inside Story. London, UK: Chapman and Hall.

Renn, Susan (n.d.). Restorative Practices as an engagement strategy in schools. http://inter-disciplinary.net/ati/education/cp/ce3/renn\%20paper.pdf

Richardson, L. (1990). Writing strategies: Researching diverse audiences. Newbury Park, CA: Sage.

Richardson, L. (1997). Fields of play: Constructing an academic life. New Brunswick, NJ: Rutgers University Press.

Rinaldi, C. (2006). In Dialogue with Reggio Emilia: Listening, researching and learning. London, UK; Routledge.

Rifkin, J. (2009). The empathic civilization: The race to global consciousness in a world in crisis. London, UK: Penguin Books.

Roberts, G. L., \& Bavelas, J. (1996). The communicative dictionary: A collaborative theory of 
meaning. In J. D. Stewart (Ed.). Beyond the symbol model: Reflections on the representational nature of language. Albany, NY: State University of New York.

Roman, L. (1996). Spectacle in the dark: Youth as transgression, display, and repression.

Educational Theory, 46 (I), 1-22.

Room, G. (ed.) (1995). Beyond the threshold: The measurement and analysis of social exclusion.

Bristol, UK: The Policy Press.

Rosenberg, M. (2005). Speak peace in a world of conflict: What you say next will change your world. Encinitas, CA: Puddle Jumper Press.

Rosenthal, R. \& Jacobsen, L. (1977). Pygmalion i klasseværelset. København, Danmark: Gyldendals Pædagogiske Bibliotek.

Rosenwald, G., \& Ochberg, R. (Eds.). Storied lives. New Haven, CT: Yale University Press.

Røn-Larsen, M. (2005). Perspektiver på de institutionelle betingelsers betydning for forældresamarbejde. In C., Højholt (Ed.). Forældresamarbejde. Forskning i Fællesskab. Virum, Danmark: Dansk Psykologisk Forlag.

Røn-Larsen, M. (Ed.), Akselvoll, M. Ø. Jartoft,, V., Knudsen, H., Kousholt, D. \& Raiths, J. K. (2014). Forældresamarbejde og inklusion - afdækning af et vidensfelt i bevægelse. Emdrup. Danmarks institut for Pædagogik og uddannelse. Retrieved 01.03.2017 from

http://www.emu.dk/sites/default/files/140815\%20Rapport\%20om\%20foraeldresamarbejde\%2 0og\%20inklusion\%20med\%20bilag.pdf

Sahlberg, P. (2015). Finnish Lessons 2.0. What can the world learn from educational change in Finland? New York, NY; Teachers College Press.

Sampson, E. E. (1993). Celebrating the other: A dialogic account of human nature. Boulder, CO: Westview Press. Richmond, VA.

Sarbin, T. R. (Ed.) (1986). Narrative psychology: The storied nature of human conduct. New York, 
NY: Praeger.

Sarbin, T. (2005). If these walls could talk: Places as stages for human drama. Journal of Constructivist Psychology, 18, 203-214. Doi.org/10.1080/10720530590948737

Schultz-Nielsen, M. L., \& Skaksen, J. R. (2016). Den økonomiske gevinst ved at inkludere de udsatte unge. København, Danmark: Rockwool Fondens Forskningsenhed.

Sen, (1999). Development as freedom. Oxford, UK; Oxford University Press.

SEU (Social Exclusion Unit) (1997). Social Exclusion Unit: Purpose, work priorities and working methods. London, UK: SEU.

Sermin, J., Devilieger, P. \& Loots, G. (2008). The narrative construction of the self: Selfhood as a rhizomatic story. Qualitative Inquiry, 14, 632-650. DOI 10.1177/1077800408314356.

Shacklock, G. \& Smyth, J. (1997). Conceptualising and capturing voices in drop out research: Methodological issues. Unpublished paper for the Students Completing Schooling Project. South Australia, Adelaide, AUS: Flinders University.

Shaw, G. (2007). Restorative practices in Australian schools: Changing relationships, changing culture. Conflict Resolution Quarterly, 25, (1), 127-135. DOI: 10.1002/crq.198

Shor, I \& Freire, P. (1987). A Pedagogy for Liberation: Dialogues on transforming education. Westport, CT: Bergin \& Garvey.

Sibley, D. (1995). Geographies of exclusion: Society and difference in the West. London, UK: Routledge. Skiba, R. J. \& Peterson, R. L. (2000). School discipline at a crossroads: From zero tolerance to early response. Exceptional Children, 66, (3), pp. 335-346. Retrieved 01.03.2017 from http://youthjusticenc.org/download/education-justice/prevention-interventionalternatives/School\%20Discipline\%20at\%20a\%20Crossroads\%20\%20From\%20Zero\%20Tolerance\%20to\%20Early\%20Response.pdf 
Skidmore, D. (2004). Inclusion: The dynamic of school development. Maidenhead, UK: Open University Press.

Skjødt, S. U. (2016). Socialformand: Udsatte unge har savnet success. Nyhedsartikel på DR Nyheder. (Retrieved 25.01.2016 from https://www.dr.dk/nyheder/indland/socialformand$\underline{\text { udsatte-unge-har-savnet-succes }}$

Skrtic, T. M. (1995). Disability and democracy: Reconstructing special education for postmodernity. New York, NY: Teachers College Press.

Slee, R. (2003). Teacher education, government and inclusive schooling: The politics of the Faustian waltz. In J. Allan (Ed.) Inclusion, participation and democracy: What is the purpose?. London, UK: Kluwer Academic Press.

Smyth, J. Shacklock, G. \& Hattam, R. (1990). Doing critical cultural studies: An antidote to being done to. Discourse, 20 (I), 73-87.

Smyth, J. (1998). Dialectical theory building: Juxtaposing theory with student voices in the noncompletion of schooling. Paper presented at the Australian Association for Research in Education Conference, Adelaide, AUS.

Smyth J. (1999). Voiced Research: Bringing in the epistemologically marginalized. Paper presented at the Australian Association for Research in Education Conference, Melbourne, AUS.

Smyth, J., Hattam, R., Cannon, J., Edwards, J., Wilson, N. \& Wurst, S. (2000). Listen to me, I'm Leaving: Early school leaving in South Australian secondary schools. Adelaide, AUS: Flinders University.

Smyth, J. \& Hattam, R. (2001). Voiced research as a sociology for understanding 'dropping out' of school. British Journal of Sociology of Education 22 (3), 401-415.

Smyth, J. \& Hattam, R. (Eds.) (2004). Dropping out, drifting off, being excluded. Becoming somebody without school. New York, NY: Peter Lang. 
Somers, M. R. (1994). The narrative constitution of identity: A relational and network approach. Theory and Society, 23, 605-649.

Sparkes, A. C. \& Smith (2008). Contrasting perspectives on narrating selves and identities: an invitation to dialogue. Qualitative Research, 8 (1), 5-35. DOI: 10.1177/ 1468794107085221.

Sparkes, A. C. \& Smith, B. (2008). Narrative constructionist inquiry. In Handbook of constructionist research (pp. 295-314). New York, NY: The Guilford Press.

Stewart, J. \& Zediker, K. (2000). Dialogue as tensional, ethical practice. Southern Communication Journal, 65 (2/3), 224-242. DOI: 10.1080/10417940009373169

Stewart, J. (2002). A philosopher's approach. In: J. Stewart (Ed.). Bridges not walls (pp. 663 681).New York: NY: McGraw Hill.

Stollenwerk, D. (Ed.) (2011). The Principal as Leader of challenging conversations. Thousand Oaks, CA: Corwin. Doi.org/10.4135/9781506335698.

Styrelsen for It og læring (2015). Notat: Trivsel og social baggrund. Den nationale trivselsmåling I Grundskolen. Retrieved 21.03. 2015 from https://www.uvm.dk/Service/Statistik/Statistik-omfolkeskolen-og-frie-skoler/Statistik-om-elever-i-folkeskolen-og-frie-skoler/Trivselsmaalinger

Suarez-Orozco, M. (1987). 'Becoming somebody': Central American immigrants in U.S. inner-city schools. Anthropology and Education Quarterly, 18 (4), 287-299. DOI: 10.1525/aeq.1987.18.4.04x0020t.

Søgaard, U. (2002). Mønsterbrud - Teorier, forskning og eksempler. København; Danmark: Billes $\varnothing$ \& Baltzer.

Søndergaard, D. M. (2009). Mobning og social eksklusionsangst. In: J., Kofoed \& D. M. Søndergaard (Eds.). Mobning. Sociale processer på afveje. København; Danmark: Hans Reitzels Forlag.

Søndergaard, D.M. (2005). At forske i komplekse tilblivelser. In: T. B., Jensen \& 
G., Christensen (Eds.): Psykologiske og pædagogiske metoder: Kvalitative og kvantitative forskningsmetoder i praksis. Frederiksberg, Danmark: Roskilde Universitetsforlag.

Tait, G. (1993). Youth, personhood and 'practices of self': Some new dir

ections for youth research.

Australian \& New Zealand Journal of Sociology, 29, (I), 40-54.

Taylor, C. (1989). Sources of the Self: The making of the modern identity. Cambridge, MA. Harvard University Press.

Taylor, S. Rizvi, F. Lindgard, B. \& Henry, M. (1997). Educational policy and the politics of change. London, UK: Routledge.

Ten Have, P. (1990). Methodological issues in conversation analysis. Retrieved 08.02.2016 from http://www.paultenhave.nl/mica.htm

Tetler, S. (2008). Historien bag begrebet 'den inkluderende skole. I R. Alenkær, Den inkluderende skole - en grundbog (pp. 31-46). 1. Udgave, 3. Oplag. Danmark; Frydenlund.

Tetler, S. (2008). Medikalisering af problemer i skolen. In I. H. Larsen. Barnet bag diagnosen. (pp. 7-10) København, Danmark: Dafolo.

Tetler, S. (2011). Inkluderet i skolens læringsfællesskab? En fortløbende problemidentifikations- og løsningsstrategi. Frederikshavn, Danmark: Dafolo.

Tetler, S., Hedegaard-Sørensen, L.. Emtoft, L. M. \& Ulvseth, H. (2012). Komparativ undersøgelse af læreres tilegnelse af specialpædagogiske kompetencer gennem uddannelse. (Danmark, Canada/Ontario, Finland, og Sverige) Rapport til Formandskabet for Skolerådet. Institut for Uddannelse og Pædagogik (DPU), Aarhus Universitets Forlag. Retrieved 01.03.2017 from http://edu.au.dk/fileadmin/www.dpu.dk/eboeger/SSIP/Rapporter/EbogKomparativ undersoegelse af laereres tilegnelse af specialpae dagogiske kompetencer.pdf 
Tetler, S. (2015a). In - og eksklusion: Når udfordrede børn og unge udfordrer skolen. In: T., Erlandsen, N. R., Jensen, S., Langager \& K.E., Petersen (Eds.). Udsatte børn og unge: En grundbog. 1. Udg. pp. 82-93. Købenahavn; Danmark: Hans Reitzes Forlag.

Tetler, S. (2015b). Inklusion - som teoretisk begreb og pragmatisk bestræbelse. In K.B. Petersen.

(Eds). Perspektiver på inklusion (pp. 17 - 28). København, Danmark: DPU, Aarhus Universitet.

The Restorative Practices Development Team (2003). Developing Restorative Practices in schools: A

resource. Hamilton, New Zealand: The University of Waikato. Retrieved 01.03.2017 from

http://www.waikato.ac.nz/ data/assets/pdf file/0018/240903/Restorative Practices for Sch

ools A Resource-1.pdf

Thomas, G. \& Loxley, A. (2001). Deconstructing special education and constructing inclusion. Maidenhead, UK: Open University Press.

Thomas, L. (2012). Building student engagement and belonging in higher education at a time of change: Final report from the What Works? Retrieved 01.03.2017 from https://www.heacademy.ac.uk/system/files/what works final report.pdf

Turner, B. S. (2008). The constructed body. In J. A. Holstein \& J.F. Gubrium (Eds.). Handbook of constructionist research (pp. 413-510). New York, NY: The Guilford Press.

Tyack, D. \& Cuban, L. (1995). Tinkering toward utopia: A century of public school reform.

Cambridge, MA: Harvard University Press.

UDKAST: Beretning om evaluering og kvalitetsudvikling af folkeskolen. April 2013. Afgivet af formandskabet for Rådet for Evaluering og Kvalitetsudvikling af Folkeskolen. Retrieved 01.03.2017 from http://www.altinget.dk/misc/Beretning\%20om\%20evaluering\%20og\%20kvalitetsudvikling\%20a f\%20folkeskolen\%202013.pdf 
UN DESA (2009) Creating an inclusive society: Practical strategies to promote social integration-Draft 2009 Retrieved 17.02.2017 from

http://www.un.org/esa/socdev/egms/docs/2009/Ghana/inclusive-society.pdf

UNESCO (1999). Salamanca five years on. A review of UNESCO activities in the light of the

Salamanca Statement and Framework for Action. Adopted at the World Conference of Special Needs Education, Access and Quality. Paris, UNESCO. Retrieved 17.02.2017 from

http://unesdoc.unesco.org/images/0011/001181/118118eo.pdf

Undervisningsministeriet (1997). Urolige elever i folkeskolens almindelige klasser. En kvantitativ og kvalitativ undersøgelse. Udført af Niels Egelund of Kim Foss Hansen. Undervisningsministeriets forlag, eksp. Gyldendal. Retrieved 01.03.2017 from https://bibliotek.dk/da/work/870970basis\%3A21993484

Undervisningsministeriet (2006). Vejledning om disciplin, god adfærd og trivsel i folkeskolen. Retrieved 14.04.2015 from http://static.uvm.dk/Publikationer/2006/disciplin/hel.html Undervisningsministeriet (2016). Notat: Sammenhængen mellem elevernes trivsel og elevernes nationale testresultater. Retrieved 01.03.2017 from http://www.uvm.dk/Aktuelt/ /UVMDK/Content/News/Udd/Folke/2016/Mar/160329-Gode-faglige-resultater-i-skolen-haenger$\underline{\text { sammen-med-god-trivsel }}$

Undervisningsministeriet (2013). Fremtidens folkeskole på vej. Pressemeddelelse d.7. Juni 2013.

Retrieved 01.03.2017 from http://www.uvm.dk/Aktuelt/ /UVM-

DK/Content/News/Udd/Folke/2013/Jun/130601-Fremtidens-folkeskole-paa-vej

Uppal, H. K. (2012). Effects of school bullying reported by participants in Undercover Anti bullying teams. Unpublished masters research project. San Bernardino, CA: California State University San Bernardino. Retrieved 01.03.2017 from 
https://books.google.dk/books/about/Effects of School Bullying Reported by P.html?id=L2C YMWEACAAJ\&redir esc $=y$

Vallerand, R.J. (1997). Toward a hierarchical model of intrinsic and extrinsic motivation. In: M,P., Zanna(Ed.). Advancesinexperimentalsocialpsychology. Volume29, (pp. 271-360). New York, NY: Academic Press. Retrieved 01.03.2017 from http://dx.doi.org/10.1016/S0065-2601(08)60019$\underline{2}$.

Vogt, E. E., Brown, J., \& Isaacs, D. (2003). The art of powerful questions: Catalyzing insight, innovation, and action. Waltham, MA: Pegasus Communications.

Weis, L. \& Fine, M. (2005). Beyond silenced voices: Class, race, and gender in United State schools (Revised Edn). Albany, NY. State University of New York.

Wexler, P. (1992). Becoming somebody: Towards a social psychology of the school. London, UK: Falmer Press.

White, M. (1989). The externalisation of the problem and the re-authoring of relationships. In M. White: Selected Papers (pp. 5-28). Adelaide, South Australia: Dulwich Centre Publications. White, M. \& Epston, D. (1990). Narrative means to therapeutic ends. New York, NY: Norton. White, M. (2007). Maps of narrative practice. New York, NY: Norton.

Wittgenstein, L. (1922) (1974): Tractatus logico-philosophicus. (D.F. Pears \& B.F. McGuinness Trans.). London: Routledge \& Kegan Paul.

Wittgenstein, L. (1953). Philosophical investigations. Oxford, UK: Blackwell.

Williams, J. R. (2012). An evaluation of Undercover Anti-Bullying Teams: Participant's personal responses. Unpublished masters research project. San Bernardino, CA: California State University San Bernardino.

Williams, M. (2010). Undercover teams: Redefining reputations and transforming bullying 
relationships in the school community. Explorations: An E-Journal of Narrative Practice, 2010 1, 4-13.

Willis, P. (1977). Learning to labour: How working class kids get working class jobs. Westmead, UK: Gower.

Winslade, J. (2006). Mediation with a focus on discursive positioning. Conflict Resolution Quarterly, 23, (4). 501-516. DOI: 10.1002/crq.152

Winslade, J. (2013). Deconstructing the policing of the normal. An examination of the work done by "Undercover Anti-Bullying Teams". In Narrative and conflict. An Examination of Theory and Practice. 1, (1), 76-98.

Winslade, J. \& Monk, G. (2000). Narrative mediation - A new approach to conflict resolution. San Francisco, CA: Jossey-Bass.

Winslade, J. \& Monk, G. (2007). Narrative counselling in schools: Powerful and brief. ( ${ }^{\text {nd }}$ Edn.). Thousands Oaks, CA. Corwin Press. DOI:org/10.4135/9781483329321.

Winslade, J., Monk, G. Crocket, K. \& Epston, D. (1997). Narrative therapy in practice - The archaeology of hope. San Francisco, CA: .Jossey-Bass.

Winslade, J. \& Williams, M. (2012). Safe and peaceful schools. Addressing conflict and eliminating violence. Thousand Oaks, California: Corwin Press.

Winslade, J., Williams, M., Barba, F., Knox, E., Uppala, H., Williams, J., Hedtke, L. (2015). The effectiveness of "Undercover Anti-Bullying Teams" as reported by participants. Interpersona - An International Journal on Personal Relationships, 9, (1), 1-99. Doi:10.5964/ijpr.v9i1.181

Winter, S. C. \& Nielsen, V. L. (2013). Lærere, undervisning og elevpræstationer i Folkeskolen. København, Danmark: SFI. Det Nationale Forskningscenter for Velfærd. Retrieved 01.03.2017 from http://www.ft.dk/samling/20121/almdel/buu/bilag/218/1243584.pdf 
Wood, J. T. (2004). Forward: Entering into dialogue. In R. Anderson, L. A. Baxter, \& K. N. Cissna (Eds.) Dialogue: Theorizing difference in communication studies (pp. xv-xxiii). Thousand Oaks, CA: Sage.

Østergaard, A. M. \& Kjær, G. (2013). Inklusionens didaktik. Frederikshavn; Dafolo.

Zehr, H. \& Toews, B. (Eds.) (2004). Critical issues in Restorative Justice. Monsey, NY, \& Cullompton, UK: Criminal Justice Press and Willan Publishing.

Zehr, H. (2002). The little book of Restorative Justice. Good Books, Intercourse PA.

Zehr, H. (2005). Evaluation and Restorative Justice principles. In E. Elliot \& R. Gordon (Eds.). New directions in Restorative Justice - Issues, practice, evaluation (pp. 296-303). Cullompton, UK: Willan Publishing.

Zipin, L., Fataar, A. \& Brennan, M. (2015). Can social realism do social justice? Debating the warrants for curriculum knowledge selection. Education as Change, 19 (2), 9-36. DOI: 10.1080/16823206.2015.1085610.

Årsrapport fra UngInvest AIB (Arbeidsinstituttet Buskerud) skoleåret 2015/2016 